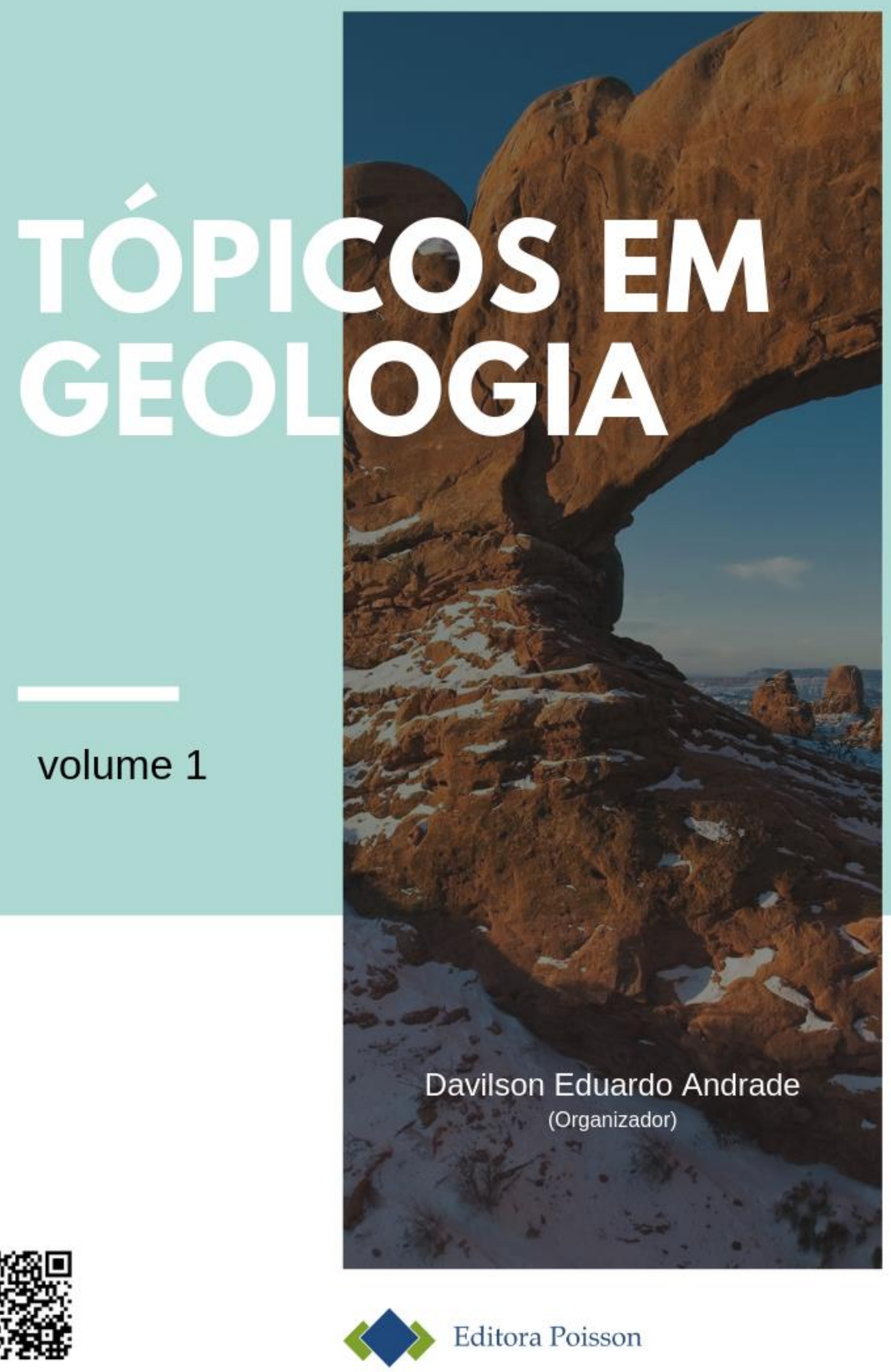


Editora Poisson

\section{Tópicos em Geologia Volume 1}

1a Edição

Belo Horizonte

Poisson

2019 
Editor Chefe: Dr. Darly Fernando Andrade

\section{Conselho Editorial}

Dr. Antônio Artur de Souza - Universidade Federal de Minas Gerais

Msc. Davilson Eduardo Andrade

Msc. Fabiane dos Santos Toledo

Dr. José Eduardo Ferreira Lopes - Universidade Federal de Uberlândia

Dr. Otaviano Francisco Neves - Pontifícia Universidade Católica de Minas Gerais

Dr. Luiz Cláudio de Lima - Universidade FUMEC

Dr. Nelson Ferreira Filho - Faculdades Kennedy

Ms. Valdiney Alves de Oliveira - Universidade Federal de Uberlândia

Dados Internacionais de Catalogação na Publicação (CIP)

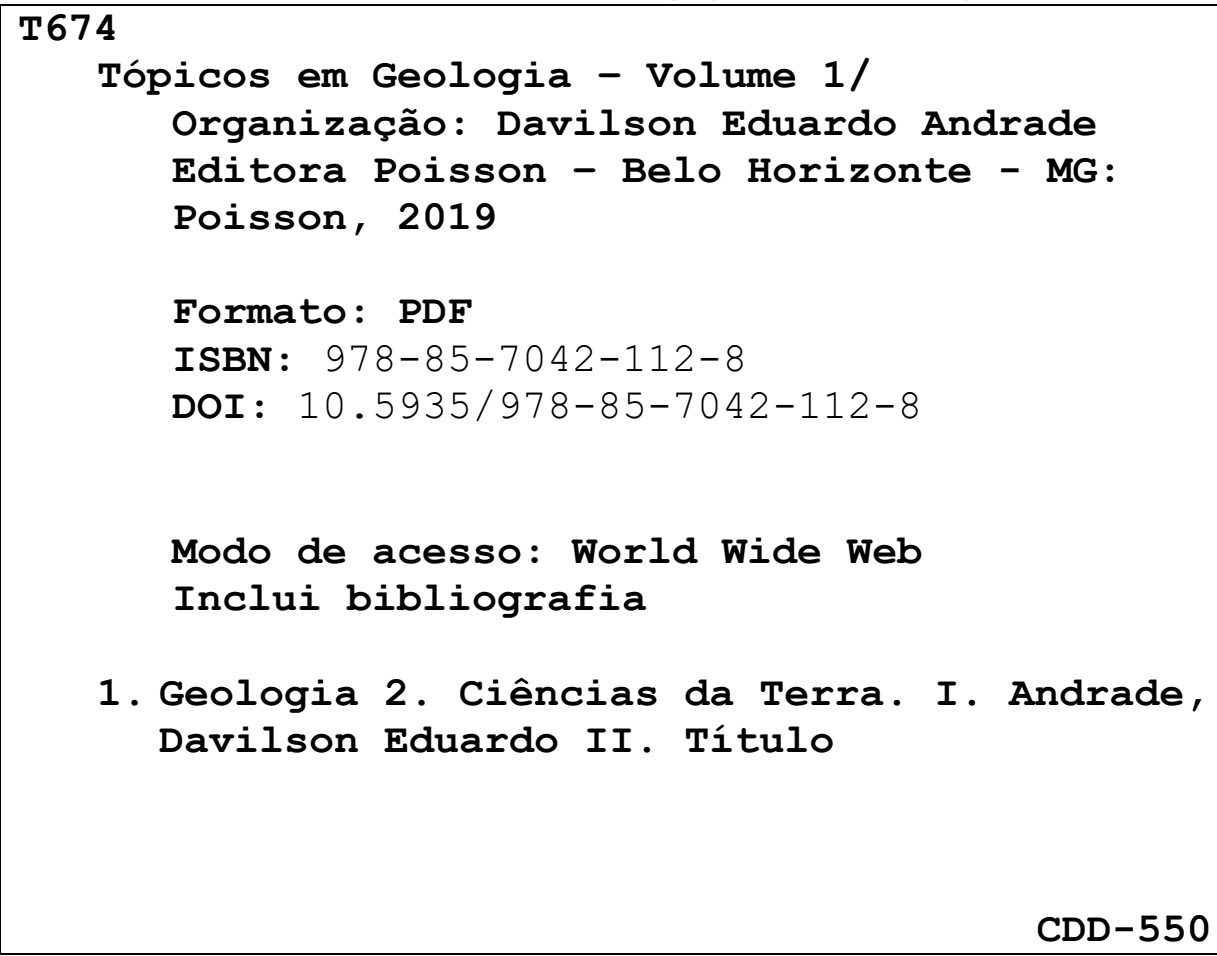

1. Geologia 2. Ciências da Terra. I. Andrade, Davilson Eduardo II. Título

O conteúdo dos artigos e seus dados em sua forma, correção e confiabilidade são de responsabilidade exclusiva dos seus respectivos autores.

\section{www.poisson.com.br}

contato@poisson.com.br 


\title{
SUMÁRIO
}

Capítulo 1: Rochas ornamentais e de revestimento em Mossoró-RN: Caracterização, métodos e ações empreendedoras 06

\author{
Edinaldo Diniz de Souza Júnior \\ Eulene Francisco da Silva \\ Marcelo Tavares Gurgel \\ Regina Celia de Oliveira Brasil Delgado \\ Eula Paula da Silva Santos \\ Diana Ferreira de Freitas \\ Flávia Giglianne Freitas Lima \\ Cleiton de Freitas Duarte
}

Capítulo 2: Determinação do teor ótimo de umidade para utilização de resíduo do beneficiamento de rochas ornamentais em solo-cimento

Caroline Forestti Oliveira

Neemias Almeida Dias

Patrício José Moreira Pires

Capítulo 3: Uso de um banco de dados na estimativa do recalque de argilas moles de Florianópolis/SC 24

Pâmela Betiatto

Gisele Marilha Reginatto

Pâmela Bogo Pessini

Amanda Fabrin

Rafael Augusto dos Reis Higashi

Capítulo 4: Comportamento de ancoragens protendidas com redução de fases de injeção 34

Rodrigo Rogério Cerqueira da Silva

Capítulo 5: Correlação entre os sistemas RMR e Q em maciços rochosos da Mina de Volta Grande, Sudeste do Brasil. 44

Daniel Silva Jaques

Klinger Senra Rezende

Eduardo Antonio Gomes Marques

Capítulo 6: Características geotécnicas das rochas encaixantes da camada de carvão barro branco da Bacia Carbonífera Sul-Catarinense

Clovis Gonzatti

João Alberto Fiorentini 


\section{SUMÁRIO}

Capítulo 7: Caracterização fisiográfica de bacia hidrográfica localizada no município de Russas/CE 60

Milena de Brito Espinosa

Robervan Alves de Araujo

Sarah Lacerda Farias

Thaynara D`Avalo Centurião

Isabel Kaufmann de Almeida

Capítulo 8: Modelagem hidrogeotécnica de áreas susceptíveis aos movimentos de massa em escala municipal usando o TauDem

Cleverson Alves de Lima

Lais Emily Assis

Eduardo Antônio Gomes Marques

Sady Júnior Martins da Costa de Menezes

Getúlio Fonseca Domingues

Capítulo 9: Análise do plano diretor de Florianópolis quanto a suscetibilidade e risco de desastres naturais

Candido Bordeaux Rego Neto

Kaliu Teixeira

Capítulo 10: Estudo do mecanismo de rockburst na Serra do Mar.

João Pedro Silva Pereira

Wilson Shoji Iyomasa

Edilson Pizzato

Autores: 


\section{Capítulo 1}

Rochas ornamentais e de revestimento em MossoróRN: Caracterização, métodos e ações empreendedoras

\section{Edinaldo Diniz de Souza Júnior}

Eulene Francisco da Silva

Marcelo Tavares Gurgel

Regina Celia de Oliveira Brasil Delgado

Eula Paula da Silva Santos

Diana Ferreira de Freitas

Flávia Giglianne Freitas Lima

Cleiton de Freitas Duarte

Resumo: 0 Rio Grande do Norte possui um potencial considerável no que se refere a extração de rochas ornamentais e de revestimento em especial para as rochas graníticas e mármores. Assim, o presente estudo objetivou caracterizar quanto à litologia os principais tipos de rochas ornamentais explorados e comercializadas em Mossoró-RN, além de analisar as empresas do município quanto ao seu nível tecnológico, operacional e logístico dos sistemas de produção. Mediante a pesquisa, foram realizadas revisões na literatura, e aplicação de questionários, contendo 37 questões objetivas, em empresas da cidade, no período de 05/11/2014 a 05/12/2014. Essas empresas foram revisitadas em março de 2019, somente para verificar se houve alguma mudança quanto à empresa e ao perfil empreendedor. Dessa forma, pode-se observar que as rochas ornamentais estão garantindo, cada vez mais, um lugar significativo no mercado da região, tendo como a principal rocha comercializada o granito. Este bem mineral se tornou acessível para todo tipo de consumidor, sendo os principais consumidores as pessoas físicas. As empresas são de pequeno a médio porte. 0 perfil da maioria dos empresários caracteriza-se como pragmáticos, os quais possuem escolaridade mediana e geralmente trabalham sozinhos, possuem acesso à internet e redes sociais, todavia, não possuem um perfil empreendedor, e não assumem uma postura de risco mercadológico. A mudança mais significativa em 2019 foi que todas as empresas estão nas redes sociais, e também divulgadas em site de busca, além disso, utilizam mensagens instantâneas online (WhatsApp) para comunicação com clientes.

Palavras-Chave: Granitos. Mármores. Empreendedorismo. Empresas. 


\section{INTRODUÇÃO}

Rochas ornamentais e de revestimento podem ser definidas como um material rochoso extraídos em blocos ou chapas, podendo ser cortados em diversos formatos e submetido a alguns processos de beneficiamento tais como esquadrejamento, polimento e lustro (COSTA et al., 2000). Neste sentido, o alto brilho da superfície polida é um fator de extrema importância, sendo utilizada no acabamento de superfícies, especialmente pisos e fachadas, em obras de construção civil, e recentemente seus resíduos finos tem sido utilizado na fabricação de piso tátil para a orientação de deficientes visuais (FERREIRA et al., 2018). As etapas da cadeia produtiva são, em síntese, a extração de bloco do maciço rochoso (matériaprima), seu transporte até as unidades de beneficiamento, o corte dos blocos em espessuras padronizadas (geralmente 1,5 - $2-3 \mathrm{~cm}$ ) e o acabamento superficial dos mesmos, sendo possível uma etapa posterior de acabamento para fabricação de outras peças (COSTA et al., 2000).

$\mathrm{Na}$ indústria das rochas ornamentais, a classificação petrográfica das mesmas não é seguida à risca. Segundo Menezes \& Larizzatti (2005) comercialmente o termo "granito" abrange, além dos granitos, os sienitos, basaltos, gabros e outros. 0 mesmo ocorre com os mármores que podem conter tipologias que não são metamórficas, tais como brechas, calcários e outros. Além dessas rochas, são utilizados também o quartzito, o arenito, o serpentinito e outros tipos (FERREIRA et al., 2018), sendo o objetivo estético o que norteia esse setor. 0 Brasil exportou no ano de 2017 cerca de 2,36 milhões de toneladas de rochas ornamentais para 117 países, onde os três principais destinos foram EUA, China e Itália. Apenas para oito países as exportações superaram US $\$ 10$ milhões. 0 preço médio das exportações avançou 1,41\%, passando de US\$463,0/t para US\$469,5/t. Nas rochas processadas, o preço médio evoluiu 2,38\%, de US\$ $663,4 /$ t para US $\$ 679,1 / t$ (ABIROCHAS, 2018).

Segundo Ministério de Minas e Energia (2017a) a mineração é responsável por cerca de 4\% do Produto Interno Bruto brasileiro (PIB) e, emprega hoje 180 mil funcionários. Atualmente, o Brasil possui umas das maiores diversidades de rochas e umas das maiores reservas, além de estar entre os principais produtores mundiais desse recurso. É o 3o maior exportador de blocos e o 5o em produtos acabados. Alguns estados brasileiros destacam-se na produção de rochas ornamentais, tais como Espírito Santo, Bahia, Ceará, São Paulo, Pernambuco, Goiás e mais recentemente, Rio de Janeiro. Dentre esses, o Espírito Santo é considerado o principal produtor de rochas ornamentais no Brasil e detentor do maior parque industrial de beneficiamento do setor, responsável por mais de $80 \%$ das exportações (MINISTÉRIO DE MINAS E ENERGIA, 2017a). O Nordeste é o segundo maior produtor de rochas do País para fins de revestimento, usados na construção civil (MINISTÉRIO DE MINAS E ENERGIA, 2017b).

Diversos fatores logísticos auxiliam a obtenção de menores custos para a cadeia de produção e comercialização da indústria de rochas ornamentais localizada no Sudeste, principalmente no Espírito Santo e Minas Gerais, isso faz com que esses estados tenham maiores vantagens para concorrer no mercado brasileiro através da adoção de estratégias de baixo custo, quando comparada com sua concorrente sediada no Nordeste. Porém, considerando o potencial existente na região Nordeste para o setor de rochas ornamentais, especificamente para rochas graníticas e mármores, esse setor merece atenção especial por parte dos pesquisadores. 0 subsolo nordestino apresenta condições favoráveis à ocorrência de rochas ornamentais como, os granitos passíveis de atender às necessidades de consumidores nacionais e inclusive aos setores internacionais (BEZERRA, 2001).

No Estado do Rio Grande do Norte, a produção mineral baseia-se principalmente na extração de petróleo, scheelita, pedras preciosas, sal e materiais de uso na construção civil (areia, argila, cascalho, rochas para produção de brita e rochas ornamentais). Quanto à produção de rochas ornamentais "há décadas que o estado produz mármores e quartzitos, e a partir da década de 90 a exploração estendeu-se para outras rochas cristalinas como os granitos, gnaisses, gabros, entre outras" (MAIA, 2004), no entanto, é irrelevante quando comparado ao Sudeste. Os granitóides do Rio Grande do Norte são rochas potencialmente promissoras de abrigar jazimentos de rochas ornamentais, sendo os granitos pegmatóides atualmente mais explorados. Segundo Angelim et al. (2007) as principais reservas de rochas ornamentais do Estado estão localizadas nos municípios de Cerro Corá, Currais Novos, Lajes, Parelhas e São José do Sabugi, seguidos por Patu, Messias Targino e São José do Campestre.

Todavia, a indústria nordestina do setor de rochas ornamentais apresenta desempenho ainda muito tímido no mercado brasileiro, e internacional, tendo sido observado em anos recentes, inclusive, a falência de muitas de suas empresas. Isso pode ser provocado provavelmente pelo perfil dos empreendedores, e a falta de informação nesse sentido pode comprometer a tomada de decisões no setor (BEZERRA, 2001). 0 crescimento econômico do setor de rochas ornamentais depende muito do perfil do gestor da empresa e, percebe-se uma carência de dados a respeito de alguns aspectos críticos sobre o empreendedor, e suas 
análises nas características das empresas, bem como, sobre suas habilidades de conhecimento, administrativas, mercadológicas e tecnológicas, o que dificulta muitas vezes a ampliação dessas empresas.

De acordo com Littunen (2000), a definição de "personalidade empreendedora, refere-se à capacidade que o indivíduo tem para correr riscos, inovar, conhecer o funcionamento do mercado, ter habilidade em marketing e em gestão empresarial que são influências para os traços de personalidade em um contexto de cooperação, networking, e também independência nos negócios". Dados referentes ao perfil desses gerentes são interessantes, pois a falta de planejamento e deficiências na gestão empresarial pode ocasionar o fechamento de empresas.

Isso se torna mais significativo quando em pesquisa realizada pelo Morais \& Souza (2014) demonstra que a principal razão para o fechamento das empresas está centrada nas falhas gerenciais, dando destaque a localização inadequada, falta de conhecimentos gerenciais e desconhecimento do mercado. Portanto, conhecer as empresas se torna fundamental para o sucesso a longo prazo. Assim, o objetivo desse trabalho foi caracterizar quanto à litologia os principais tipos de rochas ornamentais explorados e comercializadas em Mossoró-RN, além de analisar o perfil do empreendedor desse setor, seu conhecimento sobre gestão empresarial, e se há um planejamento para suas atividades ao longo prazo.

\section{CARACTERIZAÇÃO DA ÁREA ESTUDADA}

\subsection{LOCALIZAÇÃO}

O município de Mossoró está situado no Estado do Rio Grande do Norte, região Nordeste do Brasil, com coordenadas geográficas de latitude 05 11' 15" S e longitude de 37o 20' 39" W e altitude de 16 m. Pertence a mesorregião do Oeste Potiguar e limita-se com os municípios de Tibau, Grossos, Areia Branca, Serra do Mel, Açu, Upanema, Governador Dix-Sept Rosado, Baraúna e o Estado do Ceará (BELTRÃO et al., 2005). Geologicamente está inserido na Província Borborema que tem os principais domínios geológicos observados na Figura 1. No ano de 2014 a população do município foi estimada pelo Instituto Brasileiro de Geografia e Estatística (IBGE) em 284.288 habitantes. Ocupa uma área de $2.099,333 \mathrm{~km}^{2}$, e em termos de extensão territorial, recebe o título de maior município do estado do Rio Grande do Norte.

Figura 1. Principais domínios geológicos da província Borborema. Domínios Tectônicos: DMC - Médio Coreaú; DCC - Ceará Central; DRGN - Rio Grande do Norte; DZT - Zona Transversal; e DM - Meridional.

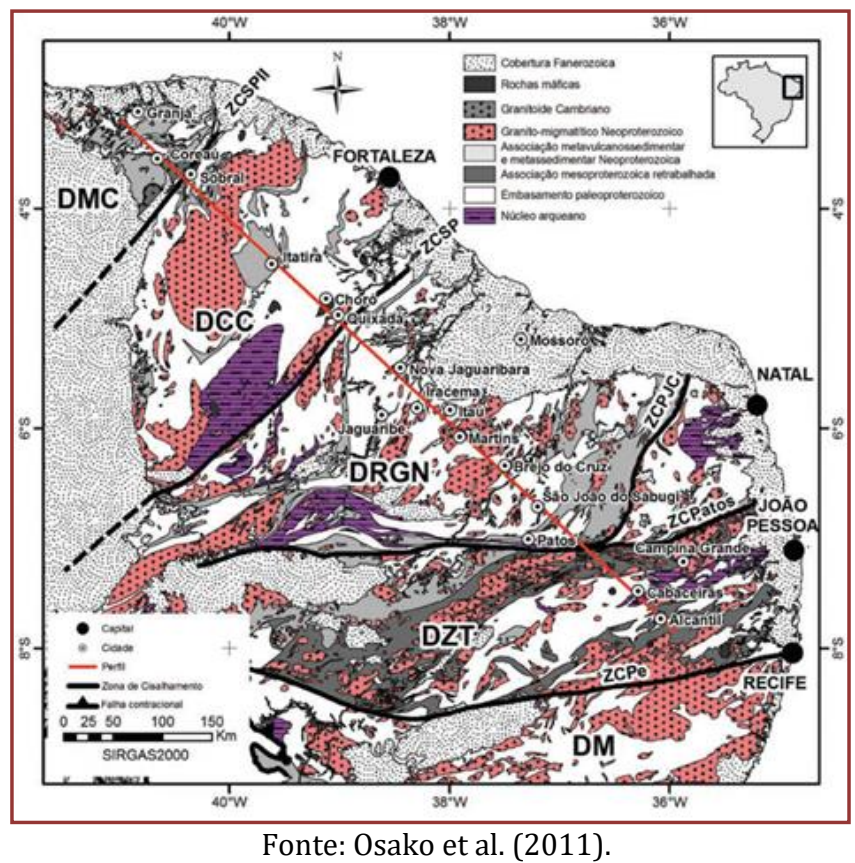




\subsection{MODELO DA PESQUISA}

Foram realizadas aplicações de questionários aos empresários do setor de rochas ornamentais no período de novembro a dezembro de 2014. Essas empresas foram revisitadas em março de 2019, somente para verificar se houve alguma mudança quanto à empresa e ao perfil empreendedor. 0 questionário consistiu de 37 questões objetivas (APENDICE), subdivididas em seis (6) categorias, abrangendo desde dados pessoais, até métodos e ações empreendedoras. As empresas submetidas aos questionários situam-se na zona urbana de Mossoró, e não terão seus nomes divulgados. Vale ressaltar a pronta colaboração dos empresários do setor para realização deste trabalho, sem nenhuma objeção em responder o questionário proposto.

Pretendeu-se caracterizar as empresas quanto aos investimentos primários para sua abertura, nível tecnológico e informações de operação e logística dos sistemas de produtos estudados. Quanto ao perfil do empreendedor, pretendeu-se analisar sua capacidade de correr riscos, inovar, conhecer o funcionamento do mercado, ter habilidade em marketing e em gestão empresarial, e se havia um planejamento para suas atividades em longo prazo. E também se havia relacionamentos entre as empresas envolvidas nesse estudo e instituições ensino. Outro fator analisado foi se havia algum tipo de interação dessas empresas com instituições de apoio, como por exemplo SENAI, SEBRAE, SINDIROCHAS, SINDIMÁRMORE, CETEMAG, CETEM, MAQROCHAS, SICOOB CREDIROCHAS e a FACI que possui o curso tecnológico em rochas ornamentais.

Os dados foram analisados e transformados em porcentagem, sendo posteriormente confeccionados gráficos utilizando o aplicativo Excel, para os resultados das questões consideradas mais relevantes para o desenvolvimento deste trabalho. Os demais resultados estão descritos no texto.

\section{RESULTADOS E DISCUSSÃO}

\subsection{ROCHAS ORNAMENTAIS COMERCIALIZADAS}

A principal rocha ornamental comercializada é o granito que representa $83,33 \%$ do lucro das empresas do setor, seguida pelo mármore $(16,67 \%)$, sendo estas geralmente comercializadas com acabamento polido (66,67\%). Segundo Maia e Heider (2011) das rochas ornamentais comercializadas no país, os granitos e similares são os mais expressivos, representando cerca de $50 \%$ da produção nacional, seguido dos mármores $(32,2 \%)$ e travertino $(17,8 \%)$. Com relação à clientela, $83,33 \%$ dos clientes são pessoas físicas, que se preocupam mais com o preço do produto $(66,67 \%)$ do que com a beleza e a durabilidade das rochas. Esses dados permaneceram inalterados em 2019. Na figura 2 podem ser observados amostras de rochas ornamentais naturais e fabricadas mais comercializados em Mossoró-RN.

Figura 2. Amostras de rochas ornamentais naturais e fabricadas mais comercializados em Mossoró-RN. Nomenclatura dada pelos comerciantes às rochas ornamentais em ordem por linha: Caixa A- Mármore

Super Nano fabricado; Mármore comum; Mármore Carrara; Mármore Travertino; Silestone Mota fabricado; Granito Branco Dallas; Granito Comum, Granito Amarelo Maracujá; Granito Amarelo Ornamental; Granito Amarelo Maracujá; Mármore Marrom Madeira; Granito Marrom Absoluto fabricado; Silestone Vermelho Estelar fabricado; Granito Verde Ubatuba; Granito Cinza Andorinha; Ardósia. Caixa Bsomente Quartizitos: Rosa; Cinza; Ferruginoso; Vermelho; Amarelo; Claro; Verde Alexandrita; Alexandrita;

A)

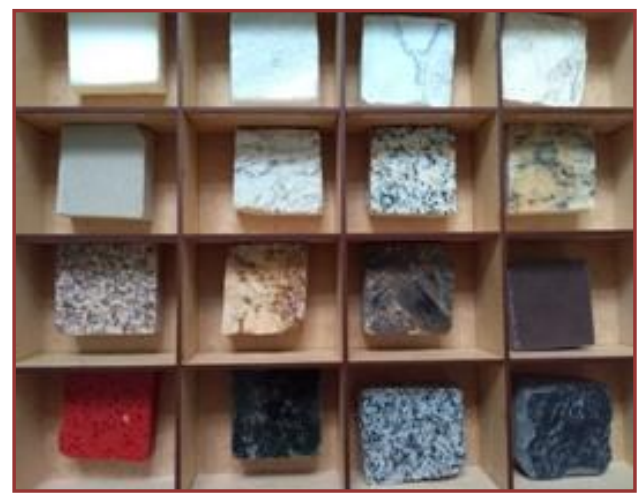

B)

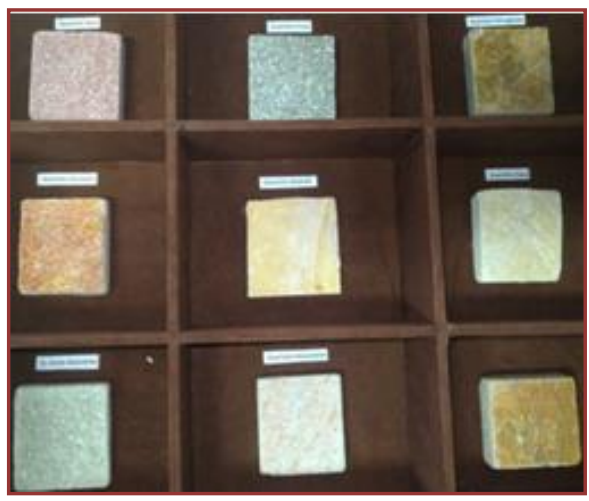


Notou-se que não há uma preocupação por parte dos comerciantes na diferenciação das rochas pela litologia. Foram observadas rochas como quartizitos, ardósias, gnaisses, esteatitos (pedra sabão) e serpentinitos sendo referenciadas comercialmente de forma incorreta como granito ou mármore. De acordo com Maia (2004), a partir da década de 90 o Rio Grande do Norte passou a explorar além de mármores e quartzitos, rochas cristalinas como os granitos, gnaisses, gabros, entre outras, denominadas industrialmente como granitos ornamentais, percebendo-se assim que esse termo é aceito na indústria para comercialização de diferentes tipos litológicos.

Para Costa et al. (2000) as rochas ornamentais mediante o conteúdo mineralógico são designadas como:

- Granitos Ornamentais: Os granitos comerciais além de apresentarem granulação variada, podem apresentar diversos tipos, discriminados em quartzo-feldspáticos representados pelos granitos verdadeiros, gnaisses migmatíticos, rochas vulcânicas ácidas e conglomerados, granitos feldspáticos correspondendo aos sienitos, os granitos máficos que correspondem às rochas básicas como gabros de grão fino e basaltos, e por último os granitos ultramáficos que correspondem a rochas ricas em serpentina, anfibólios e clorita. Essas rochas apresentam colorações que vão desde tons amarelados, brancos, cinza, vermelho ou rosa até diversos tons de verde.

- Mármores: possuem suas feições texturais fortemente influenciadas por transformações metamórficas. Em função do grau metamórfico, são granoblásticos e apresentam granulação variando de fina até média, e dentre os mais usados no setor estatutário destacam-se os de grãos finos. Os mármores podem mostrar grande variedade de cores, variando de tons amarelos, rosas, salmão, marrom e outros.

Com relação aos processos minerários em tramitação no DNPM (Departamento Nacional de Produção Mineral), no RN existem: 11 concessões de lavra, 52 requerimentos de lavra, 193 autorizações de pesquisa, 42 requerimentos de pesquisa, 02 licenciamentos, 01 requerimento de licenciamento e 32 áreas em disponibilidade. Este universo compreende em sua maioria as rochas para aplicação como revestimento, onde predominam os granitos (201), seguidos dos mármores (86), quartzitos (12) e em menor número os tipos como pegmatitos, conglomerados, gabros, basaltos, gnaisses, xistos, charnockitos e granodioritos (LIMA, 2017). Segundo Lima (2017) foram catalogados 24 (vinte e quatro) litotipos existentes neste estado: Black Stone, Cosmic Black, Abrolhos Green, Bourdeaux, Matrix Nevada, Branco Nevada, Capuccino, Branco Fuji, Iguana, Umburana, Sierra Granada, Verde Esmeralda, Verde Gauguin, Grampôla, Bianco Antico, Matrix Titânio, Branco Acari, São Tomé, Morada Nova, Xisto Ingá, Pegmatito Ingá, Galo Branco, Gogó Fino e Mont Charmot. Mais detalhes dessas rochas são fornecidos por Lima (2017), em um catálogo de rochas ornamentais dos estados do Rio Grande do Norte, Paraíba, Pernambuco e Alagoas.

\subsection{PERFIL DAS EMPRESAS E EMPRESÁRIOS}

Quanto ao perfil das empresas, para sua abertura, 50\% dos empresários investiram entre R\$10 a 15 mil reais e os outros $50 \%$ investiram acima de $\mathrm{R} \$ 15$ mil reais. No entanto, as mesmas supervalorizaram e para aquisição de uma dessas empresas atualmente, os investimentos podem variar de $R \$ 200.000,00$ a $R \$ 1,2$ milhões de reais (Figura 3), sendo que a maioria tem mais de cinco anos no mercado (66,67\%) (Figura 3), e 66,67 \% não possuem filiais. Quanto ao nível tecnológico, apesar da totalidade dos empresários classificarem este item de essencial e muito importante, observou-se que a maioria não investe $(66,67 \%)$ na aquisição de máquinas para melhoria do produto final, mesmo reconhecendo a importância da inovação de desenhos e estilo dos produtos. No ano de 2019, passado o primeiro trimestre do corrente ano, não houve mudança quanto ao nível tecnológico, mostrando-se altamente conservadores. 
Figura 3. Investimento para a aquisição de uma empresa de rocha ornamental em Reais e tempo da empresa no mercado no ano de 2014.

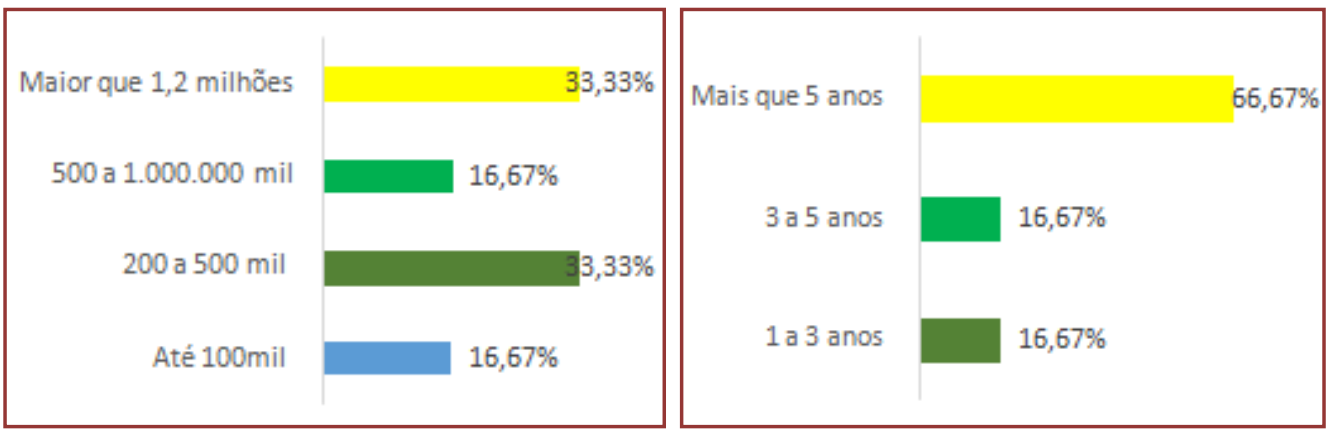

Analisando o perfil do empreendedor, a maioria dos empresários possui idade variando entre 30 a 45 anos (50\%) ou acima de 45 anos (33,33\%) mostrando certa experiência no setor, e com relação ao nível de escolaridade $66,67 \%$ não possui ensino superior completo (Figura 4). Isto reflete no interesse em consultar revistas especializadas do setor de rochas ornamentais, em que 50\% dos entrevistados consideram esta prática desnecessária. Dos empresários 33,33\% não fazem atualização de conhecimento técnico cientifico, mas $50 \%$ destes relatam que pretende fazer. Todavia, os empresários mostram interesse em consultar empresas particulares de consultoria na área (66,67\%).

Nenhuma das empresas entrevistadas exportou seus produtos, mas (66,67\%) mostraram algum tipo de interesse. Também não possuem vínculos com nenhuma instituição de ensino e pesquisa de nível superior (Universidade Federal Rural do Semi-Árido, Universidade Federal do Rio Grande do Norte, Instituto Federal do Rio Grande do Norte e Universidade Estadual do Rio Grande do Norte), apesar de 33,33\% admitirem relacionamento com institutos técnicos. No entanto, este relacionamento se dá apenas através de visitas ao local, com o objetivo de conhecer os equipamentos e os processos de beneficiamento utilizados pelas empresas. Apesar de considerarem novas estratégias de comercialização muito importantes e essenciais, a maioria dos empresários não realizam pesquisa de mercado $(66,67 \%)$ e somente 16,67\% divulgaram suas empresas em rádios e televisão, o restante (50\%) utiliza das redes sociais ou sites para sua divulgação (Figura 4). Essa foi a mudança mais marcante em 2019, onde 100\% das empresas estão nas redes sociais, e também divulgam suas empresas em site de busca, além utilizam aplicados de mensagens online (whatsApp) para comunicação com clientes.

Figura 4. Nível de escolaridade dos empresários e tipos de divulgação dos produtos em Mossoró-RN, referente à 2014 .
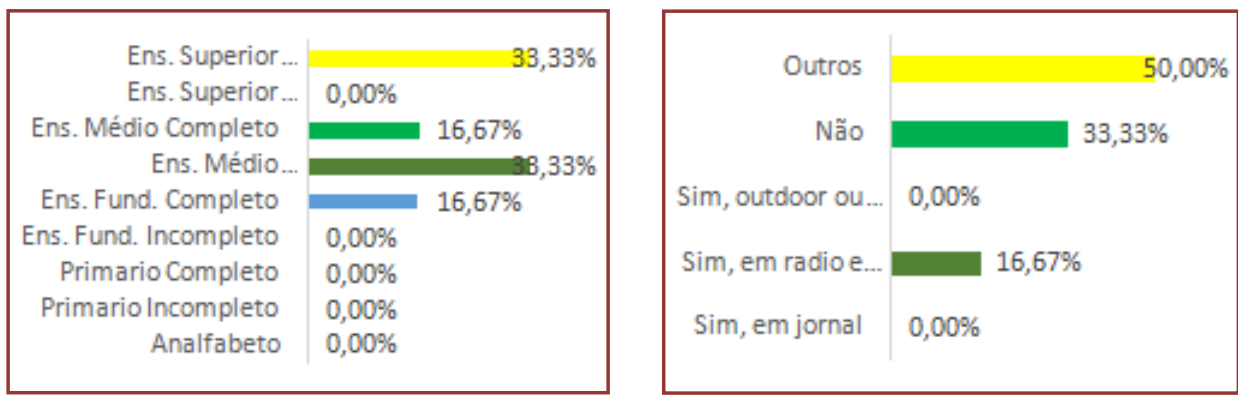

Ao serem questionados sobre o planejamento das atividades ao longo prazo, em 2014, 50\% relataram que possuem algum tipo de planejamento, todavia, não tem metas específicas nem um projeto a ser executado e o restante dos $50 \%$ admitiram que não se preocupam com isso. Sendo assim, verificou-se que há um desnorteamento ou falta de gestão empresarial em longo prazo. Nenhuma empresa tem como intenção algum tipo de investimento de risco, como bolsa de valores, preferindo permanecer na zona de conforto de algo que dominam, mas admitem que investirão mais de R 20.000 nos próximos cinco anos. Passado esse período, até o presente momento, somente $16,67 \%$ realizaram algum tipo de investimento nas empresas, todavia o valor máximo investido foi de $\mathrm{R} \$ 10.000$ reais, permanecendo a falta de gestão ao longo prazo. 


\subsection{PRINCIPAIS DIFICULDADES ENCONTRADAS}

Os principais problemas enfrentados pelas empresas são igualmente distribuídos em falta de crédito, desqualificação da mão de obra e impostos e tarifas (todos com 33,33\%). Notou-se uma preocupação dos empresários com a qualidade de mão de obra, definida como importante $(33,33 \%)$ a essencial $(66,67 \%)$. No entanto, pouco mais de $80 \%(83,33 \%)$ dos empresários se preocupam com os custos mais elevados que essa mão de obra qualificada traria, e provavelmente este fato, seja um impasse na qualificação de seus funcionários, pois não há incentivo por parte dos empregadores. Neste caso, parte do déficit da falta de qualificação é sanada pela experiência dos funcionários, pois, nestas empresas a rotatividade dos funcionários é baixa sendo que, $50 \%$ deles estão na empresa a mais de quatro anos e os $50 \%$ restantes entre dois e quatro anos. A segurança é considerada um item prioritário e $100 \%$ dos funcionários usam equipamento de proteção individual.

Segundo Clímaco (2013) um dado comum entre todos os perfis empresariais brasileiros é o grande déficit educacional destes empreendedores, fato também aqui constatado. Os três maiores problemas relatados durante o levantamento realizado no site com três mil empresários de todos os estados brasileiros, estão diretamente ligados à falta de conhecimento e abrange gestão de pessoas, fluxo de caixa e administração geral do negócio. Constata-se assim, como na pesquisa realizada pelo site, que muitos empresários acreditam que o empreendedorismo é algo intrínseco às pessoas e, portanto, colocam o preparo em segundo plano (CLÍMACO, 2013)

A maioria dos empresários do setor de rochas ornamentais da cidade de Mossoró possui a empresa em razão do grau de parentesco (herança) ou por motivação pessoal (montou sozinho), e limita-se a administrá-la de maneira conservadora, sem investir em mudanças simples a significativas, por acreditarem que isto possa representar algum fator de risco financeiro a integridade dos lucros. Para colocar algum projeto em prática, eles não demandam grandes esforços, por receio de criar alguma instabilidade na empresa. Os empresários admitem que é necessário renovação continua, atenção às mudanças de mercado, todavia, pouca iniciativa é tomada para investimentos em suas empresas. Em alguns casos, possuem a capacidade de enxergar objetivos com clareza, mas tem dificuldade de traçar planos para atingi-los, principalmente em longo prazo, não apresentando um perfil empreendedor.

\section{CONCLUSÕES}

As rochas ornamentais estão garantindo cada vez mais um lugar significativo no mercado em Mossoró-RN, tendo como a principal rocha comercializada o granito. Este bem mineral se tornou acessível para todo tipo de consumidor, sendo os principais consumidores as pessoas físicas. As empresas são de pequeno a médio porte, principalmente pela rigidez na falta de maiores investimentos, qualificação de mão de obra e receio de risco no mercadológico.

O perfil da maioria dos empresários caracteriza-se como pragmáticos, os quais possuem nível de escolaridade médio, geralmente trabalham sozinhos, possuem acesso à internet e redes sociais, todavia, não possuem um perfil empreendedor, e não assumem uma postura de risco mercadológico. Isto reflete nos resultados obtidos, os quais foram muito semelhantes nos anos de 2014 e 2019. A mudança mais significativa em 2019, foi que todas as empresas estão nas redes sociais, e também divulgam suas empresas em site de busca e utilizam mensagens instantâneas online (WhatsApp) para comunicação com clientes.

O empreendedor deve pensar em sua empresa de forma estratégica, tendo ciência dos diagnósticos e, ser capaz de enxergar os riscos de forma a transformá-los em oportunidades. Este deve ter em mente planejamentos de ações com metas e objetivos bem determinados, além de um conhecimento aprofundado na área de atuação, buscando melhores espaços através de um eficiente método de marketing e ações mercadológicas. Os conhecimentos das ferramentas disponíveis no mercado acarretariam em melhores resultados para estes empresários, gerando um novo patamar para estas empresas, impulsionando-as a ocuparem posições mais elevadas no mercado. Caso contrário, permanecerão sem crescimento significativo ao longo dos anos. 


\section{AGRADECIMENTOS}

As Empresas que participaram da pesquisa, à Universidade Federal Rural do Semi-Árido e aos Editais Primeiros Projetos (PROPPG/UFERSA) pelo suporte à Pesquisa.

\section{REFERÊNCIAS}

[1] Abirochas - Associação Brasileira Da Indústria De Rochas Ornamentais. Balanço das exportações e importações brasileiras de rochas ornamentais em 2017. Disponível em http://abirochas.com.br/wpcontent/uploads/2018/03/Informe-01-2018-Balanco-2017.pdf Acesso em 04 de abril de 2019.

[2] Angelim, L. A.A.; Nesi J.R.; Torres H.H.F.; Medeiros V.C.; Santos C.A.; Junior J.P.V.; Mendes V.A. Geologia e recursos minerais do Estado do Rio Grande do Norte - Escala 1:500.000. Recife: CPRM - Serviço Geológico do Brasil, 2007.119p.

[3] Beltrão, B. A. Souza Junior, L.C.; Morais, F.; Mendes, V. A.; Miranda, J. L. F. Projeto cadastro de fontes por abastecimento por água subterrânea: diagnóstico do município de Mossoró. Recife: CPRM/PRODEEM, 2005. 11p.

[4] Bezerra, F.D. Proposta para um plano de ações integradas para o setor de rochas ornamentais do nordeste. In: II SEMINÁRIO DE ROCHAS ORNAMENTAIS DO NORDESTE. Salvador: Bahia, 2001. Anais... 107-109 p.

[5] Clímaco, F. 0 perfil do empreendedor brasileiro. 2013. Disponível em: https://pedesenvolvimento.com/2013/05/30/o-perfil-do-empreendedor-brasileiro/. Acesso em 23/06/2015.

[6] Costa, A.G.; Campello, M.S.; Pimenta, V.B. Rochas ornamentais e de revestimento de minas gerais: principais ocorrências, caracterização e aplicações na indústria da construção civil. Geonomos, v. 8, p. 9-13, 2000.

[7] Ferreira, T.E.D.; Ferreira, E.E.; Chaves, M.B.D.S.; Gonçalves, P.H. Revista Eletrônica Engenharia de Interesse Social, v. 1, N.3, p. 1-15, 2018.

[8] Menezes, R. G.; Larizzatti, J. H. Rochas ornamentais e de revestimento: conceito, tipos e caracterização tecnológica. Curso de especialização em mármores e granitos. Ministério de Ciência e Tecnologia e Centro Tecnológico de Mármore e Granito (CETEMAG). Espírito Santo, 2005.

[9] Littunen, H. Entrepreneurship and the characteristics of the entrepreneurial personality. International Journal of Entrepreneurial Behaviour \& Research. v. 6, p. 295-310, 2000.

[10] Lima, M.A.B. Atlas de rochas ornamentais dos Estados do Rio Grande do Norte, Paraíba, Pernambuco e Alagoas. Ed. LIMA, M.A.B.; SPISILA, A.L.; Mendes, V.A. - Brasília: CPRM - Serviço Geológico do Brasil, 2017. 305p.

[11] Maia, S.M.C. Estudo integrado geológico/tecnológico de rochas ornamentais: os granitos Flores e Jacarandá, RN. Dissertação (Mestrado em geodinâmica). Universidade Federal do Rio Grande do Norte. Natal, 2004. 79p.

[12] Maia, C.M.; Heider, M. Rochas ornamentais e de revestimentos. Departamento Nacional de Produção Mineral (DNPM). Sumário Mineral 2011.128p.

[13] Ministério De Minas E Energia. Setor de rochas ornamentais é importante para ajudar crescimento econômico brasileiro. 2017a. Disponível em: http://www.mme.gov.br/web/guest/pagina-inicial/outras-noticas//asset_publisher/32hLrOzMKwWb/content/coelho-filho-setor-de-rochas-ornamentais-e-importante-para-ajudarcrescimento-economico-brasileiro-. Acesso em 05/04/2019.

[14] Ministério De Minas E Energia. Nordeste é 2o maior produtor de rochas do País. 2017b. Disponível em: http://www.brasil.gov.br/noticias/infraestrutura/2015/05/nordeste-e-2o-maior-produtor-de-rochas-do-pais. Acesso em 05/04/2019.

[15] Moraes, L.S.; Souza, L.M. Causas das falências das pequenas empresas no Brasil. Disponível em: http://semanaacademica.org.br/system/files/artigos/causasdasfalenciasdaspequenasempresasnobrasil.pdf. Acesso em $23 / 06 / 2015$.

[16] Osako, L.S. Castro, D.L.; Fuck, R.A.; Castro, N.A.; Pitombeira, J.P.A. Contribuição de uma seção gravimétrica transversal ao estudo da estruturação litosférica na porção setentrional da Província Borborema, NE do Brasil. Revista Brasileira de Geofísica, v .29, p. 309-329, 2011. 


\section{APÊNDICE \\ MODELO DO QUESTIONÁRIO UTILIZADO NA PESQUISA}

\section{I.DADOS PESSOAIS}

1.Nome:

2.Idade:

3.Formação:

() Analfabeto( ) Primário incompleto () Primário Completo () Ensino Fundamental Incompleto () Ensino Fundamental Completo ()Ensino Superior Incompleto () Ensino Superior Completo

\section{DADOS PROFISSIONAIS}

1. Nome da Empresa:

2. Profissão exercida anteriormente

( ) Empresário ( ) Não empresário ( ) Descendente de empresário

3. Capital investido inicialmente na empresa:

( ) até $R \$ 10.000,00$ ( ) entre $R \$ 10.000,01$ e $R \$ 15.000,00$ ( ) acima de $R \$ 15.000,01$

4. Há interesse do empreendedor para consultar pesquisas através de: trabalhos acadêmicos, publicações específicas, mapas geológicos, imagens de satélites e fotos aéreas:

() Desnecessário () Recomendável () Importante () Essencial

5. Para implantar um método de apuração de custo na empresa, contrataria uma consultoria particular, que lhe custaria em média $2 \%$ do faturamento:

( ) Discordo totalmente ( ) Discordo parcialmente ( ) Não concordo nem discordo ( ) Concordo parcialmente () Concordo totalmente

6. Tamanho da empresa:

() até 100 mil () 200 a 500 mil () 500 a 1.000 .000 mil () Maior que 1,2 milhões

7. Quanto tempo está no mercado:

() 1 a 3 anos () 3-5 anos () Mais que 5 anos

8. Possui filial:

() $\operatorname{Sim}$ ( ) Não

9. Empresa que fornece os produtos

\section{MÃO DE OBRA}

1. Há uma preocupação com a qualidade de mão de obra da empresa:

() Sem importância () Pouco importante () Muito importante () Essencial

2. Há uma preocupação com custo de mão de obra da empresa:

() Sem importância () Pouco importante () Muito importante () Essencial

3. Os empregados utilizam equipamento de proteção individual (EPI's):

() Sim ( ) Não ( ) Não é importante ( ) Funcionário não se importa

4. Rotatividade dos funcionários na empresa:

() Alta de 0 a 2 anos () Media de 2 a 4 anos () Acima de 4 anos. 


\section{EQUIPAMENTOS}

1. Nível tecnológico dos equipamentos:

() Sem importância () Pouco importante () Muito importante () Essencial

2. Aquisição de máquinas compradas no mercado nacional ou internacional:

() Sem importância () Pouco importante () Muito importante () Manual

\section{VENDAS, CONSUMO E CARACTERISTICAS DOS PRODUTOS}

1. Quantidade de volume de material consumido $\mathrm{em} \mathrm{m}^{2} / \mathrm{mês}$ :

2. Qual a principal rocha comercializada:

() Granito () Quartzito () Ardósia () Mármore () Gnaisses ( ) Outros

3. 0 perfil do consumidor, quanto a comercialização das rochas:

() Preço ( )Beleza ornamental () Durabilidade () Não sabe responder

4. Principais clientes:

() Empresa de construções () Pessoas físicas

5. Com relação a comercialização:

() Já exportou () Exporta ( ) Nunca exportou, mas pretende () Nunca exportou () Não respondeu

6. Tipo de acabamento das peças:

() Polido () Jateado () Outro

\section{MÉTODOS E AÇÕES EMPREENDEDORAS}

1. Principais dificuldades enfrentadas pelos empreendedores (Fernandes, 2004):

() Credito ( ) Desqualificação de mão de obra ( )Concorrência () Impostos e tarifas ( )Custo mão de obra

2. Faz algum trabalho de divulgação e marketing da empresa:

() Sim, em jornal () Sim, em Rádio e Televisão ( )Sim, outdoor ou panfletos () Não ( ) outros

3. Planejamento de atividades ao longo prazo:

() $\operatorname{Sim}$ ( ) Não ( ) Não respondeu

4. Há alguma trocam informações por meio de visitas ou reuniões com outras s firmas do setor de rochas ornamentais:

() $\operatorname{Sim}$ ( ) Não

5. Novas estratégias de comercialização:

() Sem importância () Pouco importante () Muito importante () Essencial

6. Realiza pesquisa de mercado:

( ) Sim ( ) Não () Pretende () Nunca ouviu falar

7. Estimativa dos investimentos para os próximos 05 anos:

( ) Não pretende investir () Investir R \$3 a 5 mil () R $\$ 10$ a 20 () Mais de $\mathrm{R} \$ 20$ mil

8. Tem algum vínculo com institutos técnicos de apoio:

() Sim () Não() Sim, Outros

9. Há relacionamento com alguma instituição de ensino:

() UFERSA ( ) UERN ( ) IFRN ( ) Faculdade particular. Qual () Não

10. Faz cursos de atualização sobre conhecimento técnico-cientifico: 
( ) Sim () Não ( ) Pretende

11. Inovações de desenho e estilo dos produtos:

() Sem importância () Pouco importante () Muito importante () Essencial

12. Faz alguma aplicação em bolsa de valores:

( ) Sim () Não ( )Pretende

13. Medidas de reduzir o impacto ambiental 


\section{Capítulo 2}

Determinação do teor ótimo de umidade para utilização de resíduo do beneficiamento de rochas ornamentais em solo-cimento

\section{Caroline Forestti Oliveira}

Neemias Almeida Dias

Patrício José Moreira Pires

Resumo: A indústria de beneficiamento de rochas ornamentais gera um alto volume de subprodutos, dentro os quais se destaca o resíduo do beneficiamento de rochas ornamentais (RBRO). A preocupação com este resíduo deve-se, principalmente, a dificuldade de sua adequada destinação final. Os teores de cálcio e ferro que constituem este material o tornam nocivo aos corpos d'água e sua fina granulometria pode acarretar na colmatação dos solos. Com a finalidade de encontrar uma destinação final adequada para o RBRO, este trabalho visa a sua aplicação em obras de terraplenagem. Neste sentido, foram realizados ensaios de compressão simples, segundo procedimentos da NBR 12023 (ABNT, 1992), empregando adições de 20\% de RBRO e 10\% de cimento Portland, em relação à massa de solo. Os ensaios foram realizados para diferentes teores de umidade e, a partir dos resultados, foi determinado o teor de umidade ideal para o qual a resistência à compressão da mistura é máxima.

Palavras-Chave: Resíduo do beneficiamento de rochas ornamentais; solo-cimento; curva de compactação; compressão simples. 


\section{INTRODUÇÃO}

Em razão da crescente preocupação em se mitigar o descarte inapropriado de resíduos gerados pelas atividades industriais, torna-se mais recorrente a busca por meios de fornecer uma destinação final adequada a estes resíduos ou, ainda, de reutilizá-los. 0 ramo do beneficiamento de rochas ornamentais no Brasil gera um alto volume de resíduos, haja vista a alta produção do país. Segundo a ABIROCHAS (2013, apud Heider e Maia, 2014), estima-se que a produção nacional em 2013 tenha sido em torno de 10,5 Mt, gerando cerca de 130.000 empregos diretos em 10.000 empresas, aproximadamente. A região sudeste foi responsável por 64,5\% desta produção, destacando-se o estado do Espírito Santo como principal produtor. Em termos econômicos, de acordo com o MDIC (2013, apud Heider e Maia, 2014), as 2.725 Mt de rochas ornamentais exportadas neste mesmo ano correspondem a uma receita de US\$1,3 bilhão.

Calmon et. al. (1997) apresentam a caracterização física e química do RBRO proveniente da mesma empresa de desdobramento de blocos da qual foi coletado o resíduo utilizado neste trabalho (Tabela 1). Nota-se que a composição majoritária do resíduo é de óxidos de silício, alumínio e ferro, com teores menores de óxidos de cálcio e magnésio. A presença do silício se explica pela produção e exportação de granitos e rochas silicáticas no Estado, enquanto o ferro e alumínio são em maioria resultado da presença de granalha e do desgaste dos teares pelo beneficiamento das rochas ornamentais.

Tabela 1 - Caracterização física e química do resíduo.

\begin{tabular}{|c|l|c|}
\hline \multicolumn{2}{|c|}{ Massa específica $\left(\mathrm{Mg} / \mathrm{m}^{3}\right)$} & 2,67 \\
\hline \multicolumn{2}{|c|}{ Área específica $\left(\mathrm{m}^{2} / \mathrm{kg}\right)$} & 1,295 \\
\hline & Perda ao fogo & 4,74 \\
\cline { 2 - 3 } & Óx. De Magnésio (MgO) & 3,25 \\
\cline { 2 - 3 } Componentes & Dióx. De Silício (SiO2) & 59,95 \\
\cline { 2 - 3 } Químicos (\%) & Óx. de Ferro (Fe2O3) & 6,05 \\
\cline { 2 - 3 } & Óx. de Alumínio (Al2O3) & 10,28 \\
\cline { 2 - 3 } & Óx. de Cálcio (CaO) & 6,51 \\
\cline { 2 - 3 } & Óx. De Titânio (TiO2) & 0,92 \\
\hline \multirow{3}{*}{ Álcalis Totais (\%) } & Óx. de Sódio (Na2O) & 3,39 \\
\cline { 2 - 3 } & Óx. de Potássio (K2O) & 4,48 \\
\cline { 2 - 3 } & Equival. Alcalino em Na20 & 6,34 \\
\hline \multicolumn{2}{|c|}{ SiO2 + Fe2O3 + Al203 } & 76,28 \\
\hline
\end{tabular}

Fonte: Calmon et. al (1997)

Reis (2008) realizou ensaios de lixiviação (NBR 10005/2004) e solubilização (NBR 10006/2004) e classificou o RBRO como não perigoso e inerte, ou seja, classe II-B de acordo com a NBR 10004: Resíduos sólidos - Classificação (ABNT, 2004).

Tal característica enfatiza a viabilidade de sua aplicação como material de construção. Diversos estudos a respeito do aproveitamento do RBRO já foram realizados, comprovando a possibilidade de sua utilização como material de construção civil. Calmon et al. (1997) realizaram ensaios em argamassas de assentamento substituindo, parcialmente, o cimento Portland por RBRO, obtendo melhora das características das argamassas com a utilização dos resíduos. Reis e Tristão (2010) estudaram a adição de resíduo de granito para a produção de ladrilho hidráulico piso tátil, o que resultou em aumento da resistência à flexão do produto. Para emprego em obras de terra, também foi estudado o uso do material como aditivo em misturas de solo-cimento para recuperação de taludes degradados, apresentando bons resultados para taludes de inclinações suaves (Yin e Dias, 2014).

A adição de RBRO em misturas de solos para uso em terraplenagem também já é amplamente discutida. Entretanto, sempre se associa como sendo o valor de umidade ideal para a mistura (RBRO e solo-cimento), o teor de umidade ótimo do solo determinado no ensaio de compactação. 0 presente trabalho tem como objetivo encontrar uma curva de valor ideal de umidade para a máxima resistência a compressão dos corpos de prova moldados com as misturas. 


\section{METODOLOGIA}

O solo amostral foi coletado em uma jazida localizada no município de Cariacica, Espírito Santo, nas proximidades da Rodovia Leste-Oeste, que liga este município ao município de Vila Velha. No local havia dois solos de colorações diferentes, um avermelhado e outro amarelado, sendo este último o utilizado neste trabalho. O RBRO foi coletado em uma empresa de desdobramento de blocos de rocha localizada no município de Colatina, região norte do Espírito Santo. 0 cimento Portland, do tipo CP III 40, foi adquirido em comércio local. A Figura 1 apresenta o solo e o resíduo que foram coletados.

Figura 1. Jazida do solo amostral (Yin e Dias, 2014) e lama abrasiva coletada.
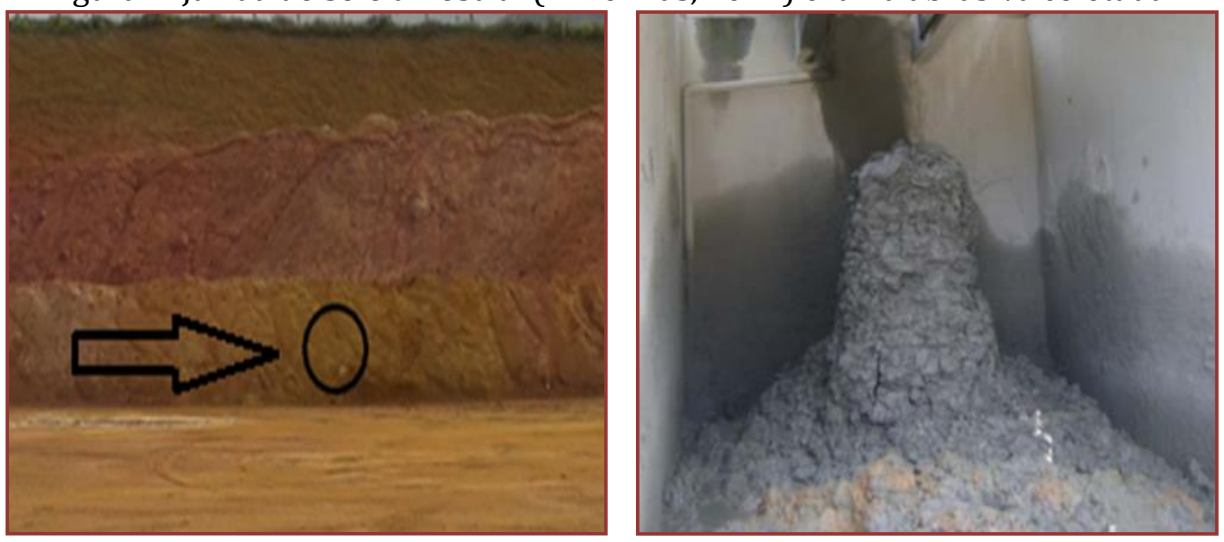

A preparação do solo amostral para realização do ensaio de compactação foi feita conforme instruções da NBR 6457: Amostras de solo - Preparação para ensaios de compactação e ensaios de caracterização (ABNT, 1986). Para as misturas, foram adicionados ao solo $20 \%$ de RBRO e $10 \%$ de cimento Portland, em massa. Os corpos de prova foram moldados utilizando esta mistura e variando os teores de umidade (Tabela 2).

Tabela 2. Dosagem dos materiais.

\begin{tabular}{|c|c|c|c|c|c|}
\hline $\begin{array}{c}\text { Corpos de } \\
\text { prova }\end{array}$ & $\begin{array}{l}\text { Solo seco } \\
\text { (g) }\end{array}$ & RBRO (g) & $\begin{array}{l}\text { Cimento } \\
\text { Portland (g) }\end{array}$ & $\begin{array}{c}\text { Umidade } \\
(\%)\end{array}$ & $\begin{array}{c}\text { Água } \\
\text { adicionada (g) }\end{array}$ \\
\hline 1 e 2 & 2190,98 & 625,71 & 312,86 & 17 & 532,09 \\
\hline 3 e 4 & 2190,98 & 625,71 & 312,86 & 19 & 594,69 \\
\hline 5 e 6 & 2190,98 & 625,71 & 312,86 & 21 & 657,29 \\
\hline 7 e 8 & 2190,98 & 625,71 & 312,86 & 23 & 719,89 \\
\hline 9 e 10 & 2190,98 & 625,71 & 312,86 & 25 & 782,49 \\
\hline 10 e 11 & 2190,98 & 625,71 & 312,86 & 27 & 845,09 \\
\hline
\end{tabular}

A moldagem dos corpos de prova seguiu procedimento da NBR 12024: Solo-cimento - Moldagem e cura de corpos de prova cilíndricos - Procedimento (ABNT, 2012). A energia empregada para compactação das amostras (Figura 2) prova foi a de Proctor normal. A justificativa para esta escolha se deu pelo fato de a NBR 12023: Solo-cimento - Ensaio de compactação (ABNT, 1992) define que se deve utilizar esta energia para o ensaio de compactação em misturas de solo e cimento. Desta maneira, visualizando uma forma de padronização de comparação de parâmetros entre os materiais, definiu-se que esta seria a energia a ser aplicada. 
Figura 2. Compactação e desforma dos corpos de prova.
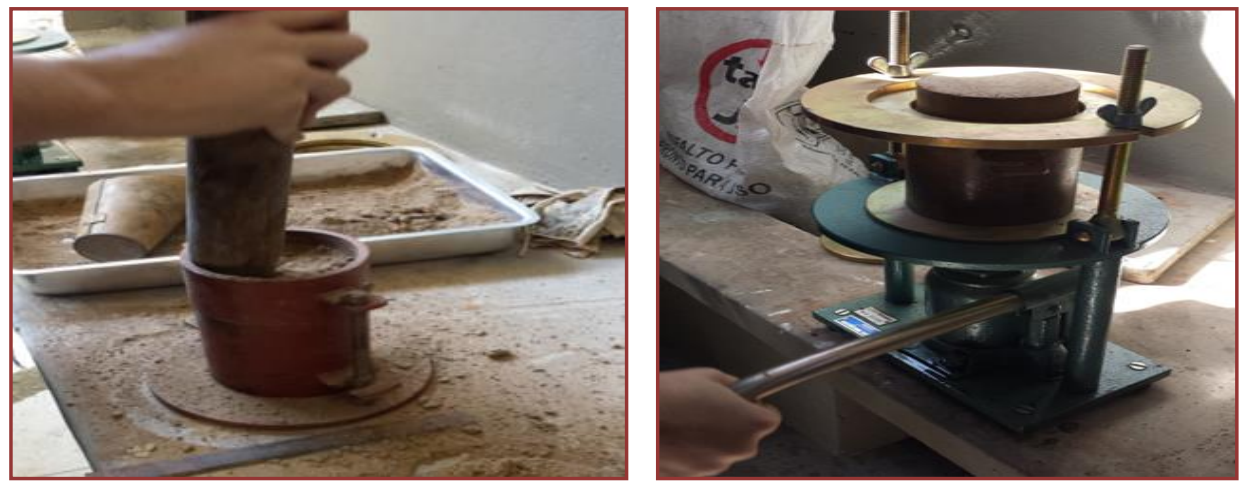

Ao longo do ensaio foram retiradas três amostras para determinação da umidade do material ensaiado. Após o término de cada compactação, os corpos de prova foram desformados, identificados, tiveram suas massas aferidas e foram levados para cura em câmara úmida (Figura 3). 0 tempo de cura utilizado para todos os corpos de prova foi de 28 dias.

Figura 3. Cura dos corpos de prova em câmara úmida.

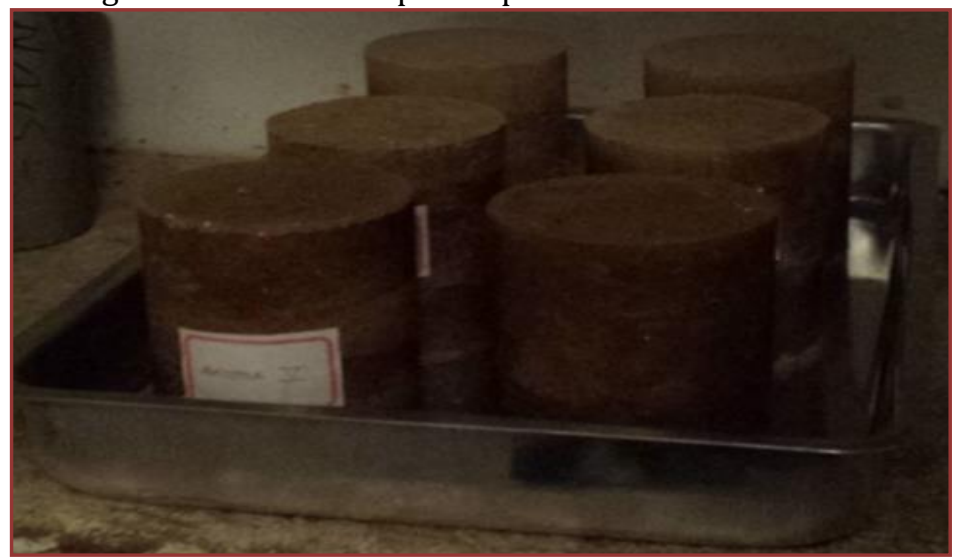

Decorrido o tempo de cura, os corpos de prova foram retirados da câmera úmida e encaminhadas para rompimento na prensa de compressão simples. A Figura 4 apresenta um dos ensaios realizados.

Figura 4. Execução do ensaio de compressão simples.
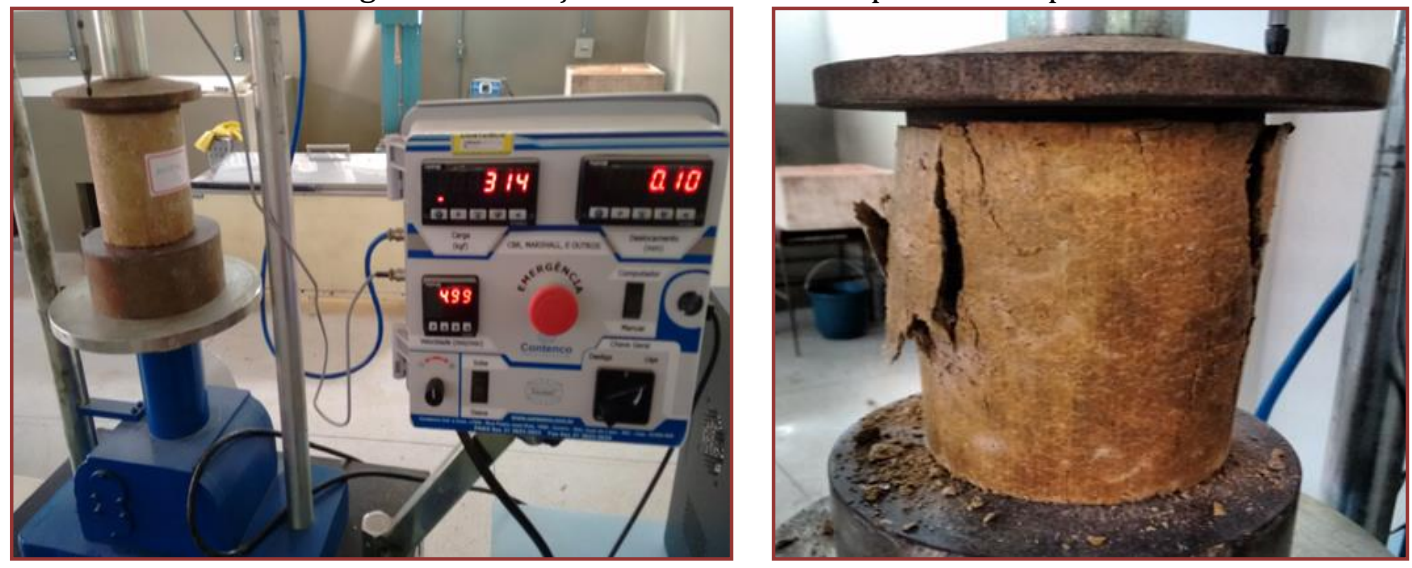


\section{RESULTADOS E DISCUSSÕES}

Os resultados dos ensaios de compressão simples, umidade e valores médios de resistência são apresentados na Tabela 2.

Tabela 2. Parâmetros obtidos no ensaio de compressão simples.

\begin{tabular}{|c|c|c|c|}
\hline $\begin{array}{l}\text { Umidade } \\
\text { (\%) }\end{array}$ & $\begin{array}{l}\text { Umidade } \\
\text { média } \\
(\%)\end{array}$ & $\begin{array}{c}\text { Tensão de } \\
\text { ruptura (MPa) }\end{array}$ & $\begin{array}{l}\text { Tensão de } \\
\text { ruptura média } \\
(\mathrm{MPa})\end{array}$ \\
\hline 13,30 & \multirow{2}{*}{14,08} & 0,6 & \multirow{2}{*}{0,9} \\
\hline 14,86 & & 1,1 & \\
\hline 16,29 & \multirow{2}{*}{15,91} & 1,0 & \multirow{2}{*}{1,2} \\
\hline 15,52 & & 1,3 & \\
\hline 17,54 & \multirow{2}{*}{17,89} & 1,4 & \multirow{2}{*}{1,9} \\
\hline 18,23 & & 2,3 & \\
\hline 19,49 & \multirow{2}{*}{19,80} & 2,5 & \multirow{2}{*}{2,5} \\
\hline 20,10 & & 2,5 & \\
\hline 21,99 & \multirow{2}{*}{21,59} & 3,1 & \multirow{2}{*}{3,2} \\
\hline 21,18 & & 3,2 & \\
\hline 23,65 & \multirow{2}{*}{23,57} & 2,2 & \multirow{2}{*}{2,3} \\
\hline 23,49 & & 2,5 & \\
\hline
\end{tabular}

A Figura 5 apresenta a curva de compactação do solo empregado na mistura (Yin e Dias, 2014). Foram encontrados os valores de 23,9\% para umidade ótima e $16,3 \mathrm{kN} / \mathrm{m}^{3}$ para o peso específico seco aparente máximo. Posteriormente, na Figura 6, são apresentadas as curvas de variação da tensão de ruptura e massa específica seca em função da variação de umidade para os corpos de prova de RBRO e solo-cimento. 0 teor ótimo de umidade e peso específico seco aparente máximo aqui encontrados foram de 21,7\% e $16,1 \mathrm{kN} / \mathrm{m}^{3}$, respectivamente.

Figura 5. Curva de compactação do solo.

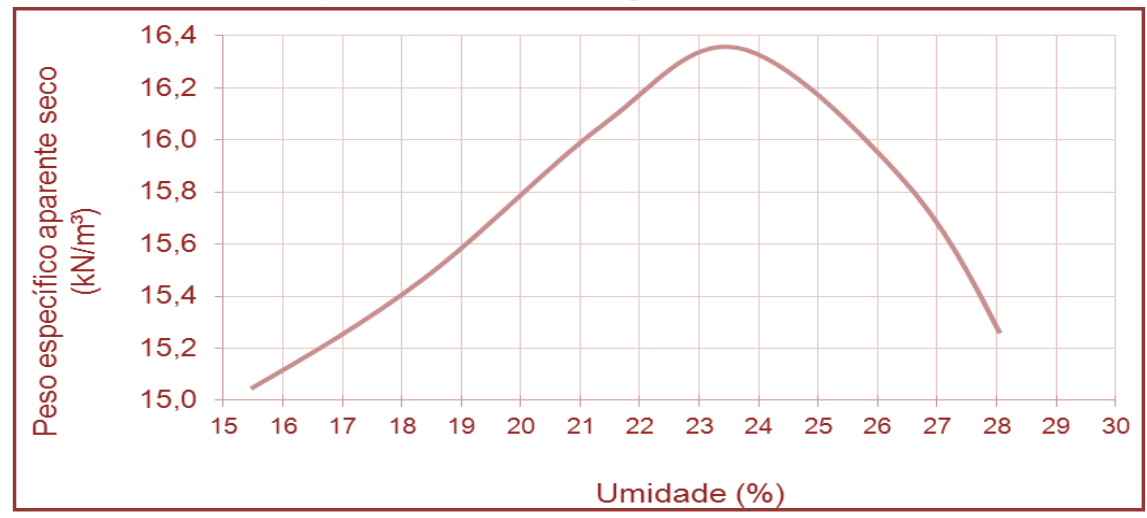

Fonte: Yin e Dias, 2014 
Figura 6. Curvas de tensão de ruptura e massa específica aparente seca para a mistura.

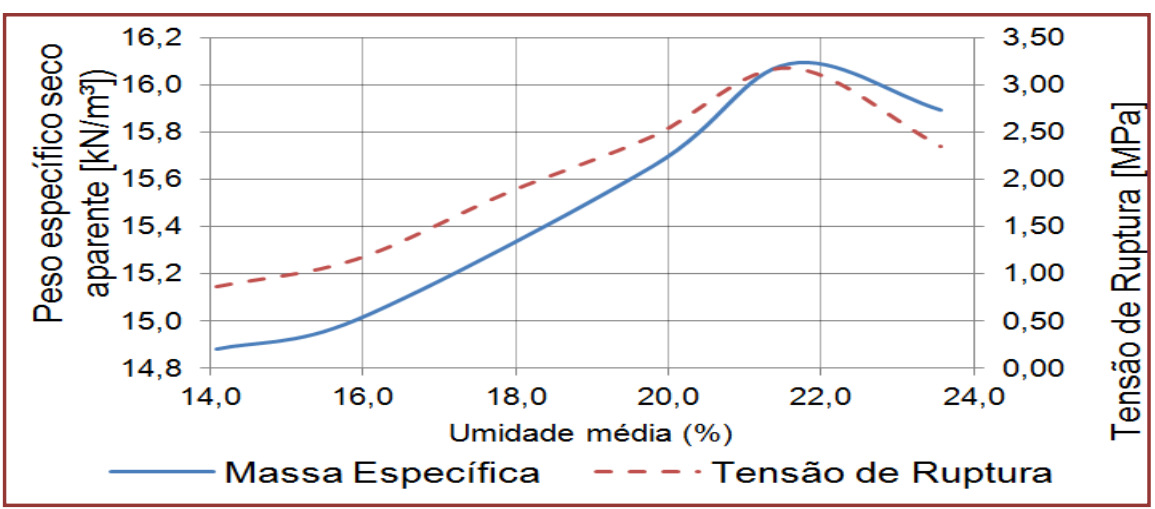

De acordo com apresentado na Figura 6, percebe-se um aumento da resistência à compressão paralelamente aos incrementos do teor de umidade até que se atingisse o valor máximo para ruptura para um teor de umidade correspondente a 21,5\%. Após este valor, a tensão de ruptura apresentou um decréscimo.

\section{CONCLUSÕES}

a) 0 ensaio de compactação da mistura de solo-cimento e RBRO apresentou menores valores de umidade ótima e peso específico seco aparente máximo em relação ao ensaio realizado no solo: 23,9\% e $16,3 \mathrm{kN} / \mathrm{m}^{3}$ para a mistura e $21,6 \% 16,1 \mathrm{kN} / \mathrm{m}^{3}$ para o solo.

b) $\quad 0$ teor de umidade para o qual a resistência à compressão atingiu seu máximo valor é próximo do teor de umidade ótima obtida no ensaio de compactação.

c) A máxima resistência à compressão obtida, 3,2 MPa, é adequada para utilização de solo cimento, uma vez que o mínimo requerido é 2,1 MPa, segundo a NBR 12253: Solo-cimento - Dosagem para emprego como camada de pavimento (ABNT, 1992).

d) Embora não se possa expressar quantitativamente a parcela de ganho de resistência que ocorreu especificamente pelo RBRO, devida à presença conjunta do cimento, a sua adição ao solo-cimento para o fim proposto neste trabalho é uma alternativa eficiente e segura como forma de destinação, por se tratar de um resíduo não inerte.

\section{AGRADECIMENTOS}

Os autores agradecem a equipe do Laboratório de Geotecnia da Universidade Federal do Espírito Santo, pelo suporte oferecido para que este trabalho fosse realizado.

\section{REFERÊNCIAS}

[1] Abnt: Associação Brasileira de Normas Técnicas - NBR 6457: Amostras de solo - Preparação para ensaios de compactação e ensaios de caracterização, Rio de Janeiro, 1986, 9p.

[2] Abnt: Associação Brasileira de Normas Técnicas - NBR 10004: Resíduos sólidos - Classificação, Rio de Janeiro, 2004, 71p.

[3] Abnt: Associação Brasileira de Normas Técnicas - NBR 12023: Solo-cimento - Ensaio de Compactação, Rio de Janeiro, 1992, 6p.

[4] Abnt: Associação Brasileira de Normas Técnicas - NBR 12024: Solo-cimento - Moldagem e cura de corpos de prova cilíndricos, Rio de Janeiro, 1992, 6p.

[5] Abnt: Associação Brasileira de Normas Técnicas - NBR 12253: Solo-cimento - Dosagem para emprego como camada de pavimento, Rio de Janeiro, 1992, 4p. 
[6] Calmon, J.L.; Tristão, F. A.; Lordêllo, F. S. S.; Silva, S. A. C.; Mattos, F. V. (1997) “Reciclagem do resíduo de corte de granito para a produção de argamassas”, I Encontro Nacional sobre Edificações e Comunidades Sustentáveis, ANTAC, Canela, RS, BR.

[7] Costa, C.C.B.; Joaquim, D. de O.; Yin, M.F.; DIAS, N.A.; Pires, P.J.M. (2014) "Emprego de misturas de solo, lama abrasiva e escória de alto forno estabilizada em terraplenagem", I Congresso Técnico Científico da Engenharia e da Agronomia, Teresina, PI, v.1, 4p.

[8] Costa, C.C.B.; Joaquim, D.O. (2014) “Avaliação do potencial de reutilização de resíduo de corte de rocha ornamental em misturas de solo-cimento para obras de terrapleanagem”, Projeto de Graduação, Departamento de Engenharia Civil, Universidade Federal do Espírito Santo, 93p.

[9] Dias, N.A.; Yin, M.F.; Costa, C.C.B.; Joaquim, D. de O.; Pires, P.J.M (2014) “Uso de misturas de solo com lama abrasiva estabilizadas quimicamente para reestabilização de taludes”, I Congresso Técnico Científico da Engenharia e da Agronomia, Teresina, Pi, v.1, 4p.

[10] Heider, M.; Maia, C.M (2014) “Rochas Ornamentais e de Revestimento”, Sumário Mineral 2014, Departamento Nacional de Produção Mineral, Brasília, DF, v. 34, 141p.

[11] Reis, A.S.; Tristão, F. A. (2010) "Ladrilho hidráulico piso tátil com adição de resíduo de beneficiamento de rochas ornamentais", Revista Ibracon de Estruturas e Materiais, v. 3, p. 390-419.

[12] Reis, A.S.; Tristão, F. A. (2008) "Estudo do aproveitamento do resíduo de beneficiamento de rochas ornamentais na fabricação de ladrilho hidráulico piso tátil.", Dissertação de Mestrado, Programa de Pós Graduação em Engenharia Civil, Universidade Federal do Espírito Santo, 218p.

[13] Yin, M.F.; Dias, N.A. (2014) “Estabilização de taludes por meio de utilização de misturas de solo com resíduo do beneficiamento de rochas ornamentais estabilizadas quimicamente", Projeto de Graduação, Departamento de Engenharia Civil, Universidade Federal do Espírito Santo, 93p. 


\section{Capítulo 3}

\section{Uso de um banco de dados na estimativa do recalque de argilas moles de Florianópolis/SC}

\section{Pâmela Betiatto}

Gisele Marilha Reginatto

Pâmela Bogo Pessini

Amanda Fabrin

Rafael Augusto dos Reis Higashi

Resumo: Este estudo objetiva estimar o recalque por adensamento primário de argilas de consistência mole a muito mole presentes em unidades geotécnicas sedimentares do município de Florianópolis, estado de Santa Catarina, a partir de dados coletados e boletins de sondagens do tipo Standard Penetration Test (SPT). Para tanto, foi elaborado um banco de dados georreferenciado contendo parâmetros físicos e de compressibilidade das argilas do litoral catarinense, a partir do qual foram geradas equações de correlação. Para determinados parâmetros, foram obtidas equações com coeficientes de correlação $\left(r^{2}\right)$ superior a 0,5, chegando até a 0,90 e 0,99 em relações envolvendo o índice de vazios, umidade e peso específico dos solos. Os recalques estimados, exceto na unidade Glei com substrato sedimentos quaternários (Gsq), em pelo menos um perfil de solo analisado, superaram $65 \mathrm{~mm}$ (limite recomendado para sapatas isoladas). Sendo que, dentre as unidades, a PodzolHidromórfico com substrato sedimentos quaternários (PZsq) foi a que apresentou maior recalque médio. Dessa forma, foi estimado para as unidades geotécnicas em estudo o comportamento das argilas moles e muito moles em relação a ocorrência de recalques, o que pode auxiliar no planejamento do território e no desenvolvimento de anteprojetos de fundações diretas na região.

Palavras-Chave: Banco de dados; recalque; equações de correlação. 


\section{INTRODUÇÃO}

No estado de Santa Catarina, sobretudo nas regiões litorâneas, há a ocorrência de um tipo de solo denominado argilas moles, cujas características de resistência ao cisalhamento e compressibilidade são desfavoráveis ao seu uso como base para fundações. Em virtude disso, por muito tempo foi evitado o uso deste solo para este fim. Entretanto, em decorrência da expansão urbana e da consequente necessidade de se aproveitar ao máximo o território, e com o avanço dos estudos e da tecnologia, essa realidade vem sendo modificada.

Existem inúmeras soluções geotécnicas que podem ser empregadas na estabilização de áreas que apresentam argilas moles, viabilizando, desta forma, a construção de obras de engenharia sobre esses solos. 0 êxito destas soluções depende sobretudo da disponibilidade e da qualidade das informaç̧ões acerca do subsolo. Visto isso, pesquisas que caracterizam as argilas moles com o intuito de compreender o seu comportamento, relacionando, por exemplo, as suas propriedades físicas, de resistência e de compressibilidade, são importantes para a execução de eficientes obras de estabilização.

Diversos autores caracterizaram as argilas moles do estado de Santa Catarina (MASSOCCO, 2013; BARAN, 2014; DRÖSEMEYER et al., 2001; CARVALHO, 2000; TELISSARI, 2011). No município de Florianópolis, por exemplo, Maccarini e Oliveira (2001), Moura (2004), Oliveira (2006), e Espíndola (2011), determinaram para este tipo de solo, parâmetros físicos, de resistência e de compressibilidade. Santos (1997), a partir do mapa geotécnico da ilha de Santa Catarina determinou áreas de solos (unidades geotécnicas) residuais e sedimentares, caracterizando-as através de ensaios. Esse autor, além de relacionar os parâmetros obtidos à origem dos solos, a partir do mapeamento geotécnico, organizou os dados em um banco de dados georreferenciado, possibilitando inúmeras análises.

0 mapeamento geotécnico é uma ferramenta útil na gestão do meio físico, representando, a partir de uma mapa ou de uma carta geotécnica, uma maneira de se prever o comportamento dos solos (HIGASHI, 2006). Dentre as metodologias de mapeamento geotécnico, cita-se a de Davison Dias (1995), desenvolvida para grandes áreas em solos tropicais. Esta metodologia define que, a partir de informações geológicas, pedológicas e topográficas (curvas de nível), é possível obter um mapa de estimativas de unidades geotécnicas, ou seja, áreas cujo solo apresenta comportamento geomecânico semelhante em função da sua gênese.

Segundo Bastos et al (2005) o banco de dados é um dos principais elementos para a elaboração de mapas ou cartas geotécnicas. De acordo com Paredes (1994) o banco de dados representa uma estrutura que armazena registros de forma integrada ou partilhada, permitindo que dados individuais ou que a combinação de vários dados seja utilizada por diferentes programas. Yuaça (2003) afirma que um banco de dados interligado a um SIG, vem sendo empregado para diversos fins e em várias cidades brasileiras. Coutinho e Oliveira (1994), por exemplo, elaboraram um banco de dados contendo propriedades geotécnicas das argilas moles do Recife, que auxilia, dentre outros, na elaboração de projetos de fundação.

A elaboração de um banco dados também possibilita a determinação de equações de correlação, o que se mostra bastante útil, especialmente em mapeamentos preliminares e de grandes áreas, onde há a necessidade de uma grande quantidade de dados. 0 uso de equações de correlação diminui o número de ensaios necessários para a caracterização dos solos, bem como, o tempo e o custo que seriam empregados na determinação dos mesmos. Além disso, possibilita a determinação de parâmetros de resistência e de compressibilidade dos solos a partir de dados obtidos em ensaios de caracterização física.

Autores como Terzaghi e Peck (1948 apud PINTO, 1998), Costa Filho et al. (1985), Ortigão (1995), Kulhawy e Mayne (1990 apud Das, 2013) e Morettin et al (2012), relacionaram os parâmetros físicos Limite de Liquidez (LL) ou Índice de Plasticidade (IP) dos solos ao coeficiente de compressibilidade (Cc). 0 coeficiente Cc é empregado no cálculo do recalque por adensamento primário de determinados solos e é obtido de forma direta a partir do ensaio de adensamento unidimensional (NBR 12007/1990). Além dos referidos autores, destacam-se Teixeira e Godoy (1998), Drösemeyer e Müller (1999) e Higashi (2006), os quais elaboraram equações de correlação para os solos de Santa Catarina. Drösemeyer e Müller (1999), obtiveram em seus estudos coeficiente de correlação $\left(\mathrm{r}^{2}\right)$ igual a 0,54 e Higashi (2006) igual a 0,90.

Desta forma, o presente estudo objetiva caracterizar em termos de recalque as argilas moles presentes em determinadas unidades geotécnicas sedimentares do município de Florianópolis/SC, a partir de parâmetros de compressibilidade determinados por equações de correlação. Estas equações foram geradas com base em parâmetros geotécnicos já determinados em solos da região litorânea do estado, organizados em um banco de dados georreferenciado em ambiente SIG, relacionando dados de ensaios mais complexos àqueles obtidos em ensaios simples e de baixo custo. Com isso, esse estudo, além da 
caracterização dos solos, disponibiliza informações que auxiliarão na elaboração de anteprojetos de fundações superficiais sobre argilas moles da região analisada.

\section{CARACTERIZAÇÃO DA ÁREA DE ESTUDOS}

\subsection{LOCALIZAÇ̃̃O}

Esse estudo foi realizado no município de Florianópolis, localizado na região leste do Estado de Santa Catarina, entre os paralelos $27^{\circ} 22^{\prime}$ e $27^{\circ} 50^{\prime}$ de latitude sul e os meridianos de $48^{\circ} 20^{\prime}$ e $48^{\circ} 35^{\prime}$ de longitude oeste (SANTOS, 1987). Foram analisados os solos das seguintes unidades geotécnicas sedimentares: Areias Quartzosas Hidromórficas com substrato sedimentos quaternários (AQsq1), Cambissolo com substrato depósito de encosta (Cde), Dunas com substrato sedimentos quaternários (DNsq), Solo PodzolHidromórfico com substrato sedimentos quaternários (PZsq) e Glei com substrato sedimentos quaternários (Gsq), individualizadas no mapa geotécnico da Ilha de Santa Catarina, elaborado por Santos (1987) na escala 1.50.000, a partir de metodologia de Davison Dias (1995), conforme apresentado na Figura 1.

Figura 1. Mapa geotécnico da Ilha de Santa Catarina com as unidades geotécnicas analisadas.

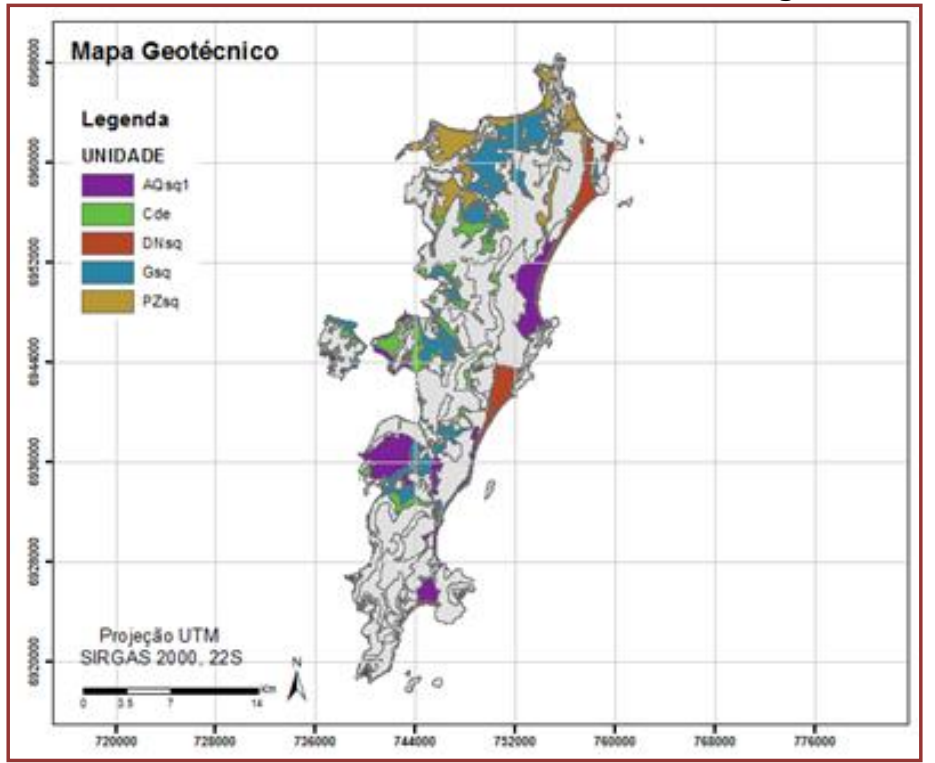

\subsection{CARACTERIZAÇÃO GEOLÓGICA E GEOTÉCNICA}

Em relação a Cobertura Sedimentar Quaternária da planície costeira do estado de Santa Catarina, segundo Koerich et al. (1991), ocorrem depósitos marinhos, aluvionares, lagunares, eólicos e coluvionares. Na Ilha de Santa Catarina, por sua vez, de acordo com o mapa geotécnico de Santos (1987), a cobertura sedimentar é formada por oito unidades geotécnicas, dentre as quais, as unidades AQsq1, Cde, DNsq, PZsq e Gsq foram selecionadas para a estimativa do recalque por adensamento primário.

De acordo com Santos (1987), os solos da unidade AQsq1 são formados pela associação das seguintes classes de solos: Areias Quartzosas Hidromórficas, Areias Quartzosas Marinhas, Podzólico e Glei. Apresentam alto grau de hidromorfismo, com lençol freático localizado próximo ou à superfície do solo. Apresentam um elevado teor de areia fina com silte no horizonte superficial, onde também se encontra uma porcentagem relativamente alta de matéria orgânica.

Quanto a unidade Cde, ocorre em região de relevo suave ondulado, apresentando uma associação de Cambissolo com textura arenosa e média, Plintossolo com textura arenosa e média e Podzólico Vermelho Amarelo com textura média argilosa (SANTOS, 1987). A textura do Cambissolo é bastante variável, dependendo do material de origem e da energia de transporte das partículas, e apresenta drenagem que oscila entre acentuada até imperfeita. A unidade DNsq é formada pela associação de Dunas e Areias Marinhas com substrato sedimentos quaternários. São solos que originaram-se quase que exclusivamente 
de deposições eólicas de material arenoso-quartzoso. São formadas por perfis profundos, homogêneos e sem estrutura de origem pedológica (SANTOS, 1987).

A unidade PZsq compreende a classe dos solos Podzol Hidromórficos e Areias Quartzosas Hidromórficas com substrato sedimentos quaternários. São solos minerais, hidromórficos, ácidos e com predominância de textura arenosa ao longo de todo perfil (SANTOS, 1987). Ocorrem em áreas de relevo plano. Em Gsq, foram reunidos solos do tipo Glei associados às Areias Quatzosas Hidromórficas e à Solos Orgânicos, com substrato sedimentos quaternários, de textura argilosa, siltosa e média. Ocorrem em áreas de relevo plano e apresentam argila de atividade alta, indicando a ocorrência de expansão e contração em função da variação de umidade (SANTOS, 1987).

\section{MATERIAIS E MÉTODOS}

\subsection{ELABORAÇÃO DO BANCO DE DADOS E DE EQUAÇÕES DE CORRELAÇÃO}

Foram coletados, de pesquisas anteriores, parâmetros geotécnicos relacionados aos solos moles de regiões litorâneas do estado de Santa Catarina (abrangendo desde o litoral norte até o litoral sul) dando ênfase ao município de Florianópolis. O conjunto desses dados foram compilados em um banco de dados georreferenciado em ambiente SIG (software ArcGis) e possibilitaram a caracterização de unidades geotécnicas da Ilha de Santa Catarina e a elaboração de equações de correlações. Tais equações foram elaboradas utilizando somente os dados relacionados ao município de Florianópolis, visando a estimativa do recalque por adensamento primário dos solos dessa região.

Os parâmetros dos solos considerados na elaboração do banco de dados foram os seguintes: índice de vazios $(e)$, teor de umidade $(w), \mathrm{N}_{\mathrm{SPT}}$ médio, coeficiente de compressibilidade $(\mathrm{Cc})$, razão de compressão $(\mathrm{CR})$, coeficiente de adensamento (Cv), limite de liquidez (LL); limite de plasticidade (LP), índice de plasticidade (IP); peso específico natural $(\Upsilon)$; tensão de pré-adensamento $\left(\sigma_{p}^{\prime}\right)$, razão de pré adensamento (OCR).

Na busca de equações de correlações, com o auxílio do software Excel, foram relacionados os seguintes parâmetros geotécnicos: $(e)$ e w, $(e)$ e CR, $(e)$ e LL, $(e)$ e IP, $(e)$ e $\gamma_{n a t},(e)$ e Cv, $(e)$ e Cc, Cc e $w$, Cc e CR, Cc e $\mathrm{LL}, \mathrm{Cc}$ e IP, Cc e $\gamma_{\text {nat }}, \mathrm{Cc}$ e Cv, Cc e $e$, CR e LL, CR e IP, CR e Cv, CR e $w$, CR e $\gamma_{\text {nat }}$, CR e Cc, CR e (e). Para tanto, foram elaborados gráficos onde a variável $\mathrm{Y}$ foi representada pelos parâmetros (e), Cc $e \mathrm{CR}$, e a variável X foi representada pelos demais parâmetros. De acordo com o limite proposto por Karunaprema e Edirisingh (2005 apud HIGASHI, 2006), somente as relações com $r^{2}$ superior a 0,5 foram consideradas satisfatórias.

\subsection{CÁLCULO DO RECALQUE POR ADENSAMENTO PRIMÁRIO ( $\rho$ )}

Inicialmente foram selecionados os perfis de solos para os cálculos dos recalques. Para tanto, foram analisadas sondagens do tipo SPT, previamente locadas sobre o mapa geotécnico da Ilha de Santa Catarina, em ambiente SIG (software ArcGis), pela equipe do LAMGEO (Laboratório de Mapeamento Geotécnico da UFSC).

Para a escolha dos perfis de SPT foi determinada a profundidade de influência do bulbo tensões (z) adotando uma sapata tipo estabelecida por Fabrin (2017) e seguindo as premissas de Cintra et al (2011). Trata-se de uma sapata isolada de base quadrada (B), cujo valor de B é igual a $1,5 \mathrm{~m}$ e a altura de embutimento (h) é igual a 1 metro (conforme recomendação da norma NBR 6122/1996). Sabendo-se que, para sapatas de base quadrada, $90 \%$ da propagação da tensão no solo ocorre até a profundidade equivalente a duas vezes a dimensão da sua base (B), a profundidade de influência do bulbo de tensões (z) para B igual a $1,5 \mathrm{~m}$ corresponde a $3,0 \mathrm{~m}$ abaixo da base da sapata. Sedo assim, para cada SPT foram analisadas as camadas de solo até a profundidade de $3 \mathrm{~m}$ a partir da quota de embutimento da sapata (igual a $1 \mathrm{~m}$ ).

Foram selecionados os perfis de SPT cujas características dos solos até a profundidade de $4 \mathrm{~m}$ foram as seguintes: textura argilosa ou predominantemente argilosa, NSPT entre 1 e 5 (caracterizando solos de consistência muito mole e mole de acordo com a NBR 7250/1982) e nível d'água abaixo de $1 \mathrm{~m}$ de profundidade (visando diminuir o custo de execução da sapata). Além disso, foram desconsiderados os perfis formados por camadas de aterros, por tratar-se de um solo que pode estar em processo de adensamento (OCR menor do que 1), e aqueles onde houve a intercalação entre camadas de areia e argila. 
Na sequência, foram calculados os recalques para as camadas de solo quando submetidas à carga imposta pela sapata tipo a partir da equação (1). Ao utilizar essa equação, considerou-se que as argilas se encontram no estado mais crítico, ou seja, no estado normalmente adensado (NA), onde o OCR é igual a 1.

$$
\rho=H \times \frac{C c}{1+e} \times \log \frac{\sigma_{f}^{\prime}}{\sigma_{i}^{\prime}}
$$

Onde H é a espessura da camada de solo mole ou muito mole em metros, Cc é o índice de compressão (adimensional), $e$ é o índice de vazios (adimensional), ? ? ${ }_{\mathrm{i}}$ é a tensão efetiva inicial $\mathrm{em} \mathrm{kN} / \mathrm{m}^{2} \mathrm{e}$ ? ? ${ }_{\mathrm{f}}$ é a tensão efetiva final em $\mathrm{kN} / \mathrm{m}^{2}$.

Para determinar as variáveis que compõem a equação (1) foram utilizadas correlações propostas nesse estudo e propostas por outros autores. Na determinação do Cc foi adotada a equação (2) de Higashi (2006), cujo $r^{2}$ é de 0,90 .

$$
C c=0,3821 e-0,21
$$

Onde o $e$ (índice de vazios) foi determinado a partir da equação (3), proposta pelas correlações desse estudo, cujo $\mathrm{r}^{2}$ é de 0,90 .

$$
e=-1,4628 \gamma_{\text {argila }}+23,906
$$

Onde o $\gamma_{\text {argila }}$ é o peso específico mais crítico da camada de solo mole ou muito mole, em $\mathrm{kN} / \mathrm{m}^{3}$. $0 \gamma_{\text {argila }}$ foi determinado com base na proposta de Godoy (1972 apud Cintra et al., 2011) apresentada na Tabela 1, utilizando o menor valor de NSPT até a profundidade de $4 \mathrm{~m}$, representando o solo menos resistente.

Tabela 1 - Peso específico de solos argilosos segundo Godoy (1972).

\begin{tabular}{|c|c|c|}
\hline NspT & Consistência & Peso Específico $-\Upsilon\left(\mathrm{kN} / \mathrm{m}^{3}\right)$ \\
\hline$\leq 2$ & Muito mole & 13 \\
\hline $3-5$ & Mole & 15 \\
\hline $6-10$ & Média & 17 \\
\hline $11-19$ & Rija & 19 \\
\hline$\geq 20$ & Dura & 21 \\
\hline
\end{tabular}

Fonte: Cintra et al. (2011).

A tensão efetiva inicial $\left(\sigma_{i}^{\prime}\right)$ representa o valor da tensão atuante sobre a camada de solo mole ou muito mole sem considerar o efeito da sapata tipo e foi calculada conforme apresentado na equação (4). Essa tensão foi calculada no meio da camada de solo mole ou muito mole.

$$
\sigma i^{\prime}=\left(\gamma_{\text {argila }} \times z_{\text {argila }}\right)-\left(\gamma_{w} \times h_{w}\right)
$$

Onde $Z_{\text {argila }}$ é a espessura da camada de solo mole ou muito mole em metros, $\gamma_{w}$ é o peso específico da água, considerado igual a $10 \mathrm{kN} / \mathrm{m}^{3}$ e $\mathrm{z}_{\mathrm{w}}$ é altura da coluna d'água em metros.

Em perfis de SPT onde foram identificadas camadas de solo drenante acima da camada de solo mole ou muito mole (representando uma sobrecarga) a $\sigma_{i}^{\prime}$ foi calcula a partir da equação (5).

$$
\sigma i^{\prime}=\left(\gamma_{\text {argila }} \times z_{\text {argila }}\right)+\left(\gamma_{\text {areia }} \times z_{\text {areia }}\right)-\left(\gamma_{w} \times h_{w}\right)
$$


Onde o $\gamma_{\text {areia }}$ é o peso específico da camada drenante, determinado segundo a Tabela 2 e zareia é a espessura da camada drenante em metros. No cálculo da $\sigma_{i}^{\prime}$, adotou-se ainda, para o primeiro metro de solo onde não há dados de NSPT peso específico $(\gamma)$ igual ao da camada subjacente.

Tabela 2 - Peso específico de solos arenosos segundo Godoy (1972).

\begin{tabular}{|c|c|c|}
\hline $\mathrm{N}_{\text {SPT }}$ & Compacidade & $\begin{array}{c}\text { Peso Específico }-\Upsilon \\
\left(\mathrm{kN} / \mathrm{m}^{3}\right)\end{array}$ \\
\hline$<5$ & Fofa & 13 \\
\hline $5-8$ & Pouco Compacta & 15 \\
\hline $9-18$ & Medianamente Compacta & 17 \\
\hline $19-40$ & Compacta & 19 \\
\hline$\geq 40$ & Muito Compacta & 21 \\
\hline
\end{tabular}

Fonte: Cintra et al. (2011).

A tensão efetiva final $\left(\sigma_{\mathrm{f}}^{\prime}\right)$ foi determinada a partir da soma da $\sigma_{i}^{\prime}$ e da tensão aplicada pela sapata tipo $\left(\sigma_{\text {sapata }}\right)$, conforme apresentado na equação 6 . Onde a $\sigma_{\text {sapata }}$ igual a $17,79 \mathrm{kN} / \mathrm{m}^{2}$.

$$
\sigma_{f}^{\prime}=\sigma_{i}^{\prime}+\sigma_{\text {aplicada }}
$$

Após a estimativa dos recalques, os resultados foram relacionados as unidades geotécnicas da Ilha de Santa Catarina para a caracterização daquelas de origem sedimentar, cujos perfis de SPT foram selecionados.

\section{RESULTADOS}

A compilação de parâmetros geotécnicos relacionados aos solos moles de municípios de Santa Catarina, em um banco de dados em SIG, possibilitou a verificação da variação de parâmetros necessários à estimativa do recalque nessas regiões, tais como: índice de vazios $(e)$, coeficiente de compressibilidade (Cc) e razão de compressão (CR). Na Tabela 3, são apresentadas as regiões de Santa Catarina analisadas com a respectiva variação e média dos parâmetros de interesse.

Tabela 3 - Variação dos parâmetros de interesse para as regiões de Santa Catarina.

\begin{tabular}{|c|c|c|c|c|c|}
\hline Região de SC & Autores & Valores & $e_{0}$ & Cc & CR \\
\hline \multirow{3}{*}{ Florianópolis } & \multirow{3}{*}{$\begin{array}{l}\text { Santos (1997); Moura (2004); Oliveira } \\
\text { (2006); Maccarini e Oliveira (2001); } \\
\text { Espíndola (2011). }\end{array}$} & Mínimo & 2,087 & 0,54 & 0,100 \\
\hline & & Médio & 3,29 & 2,77 & 0,3155 \\
\hline & & Máximo & 4,5 & 5,0 & 0,531 \\
\hline \multirow{3}{*}{ Sul } & \multirow{3}{*}{$\begin{array}{l}\text { Higashi (2006); Chaves e Orsi (2007); } \\
\text { Massoco (2013). }\end{array}$} & Mínimo & 1,27 & 0,25 & 0,097 \\
\hline & & Médio & 5,01 & 1,685 & 0,317 \\
\hline & & Máximo & 8,75 & 3,12 & 0,537 \\
\hline \multirow{3}{*}{ Norte } & \multirow{3}{*}{$\begin{array}{l}\text { Moura (2004); Telissari (2011); } \\
\text { Marques e Lacerda (2004). }\end{array}$} & Mínimo & 0,96 & 0,1 & 0,09 \\
\hline & & Médio & 1,89 & 0,635 & 0,23 \\
\hline & & Máximo & 2,82 & 1,17 & 0,37 \\
\hline \multirow{3}{*}{ Leste } & \multirow{3}{*}{ Drösemeyer, Maccarini et al (2001). } & Mínimo & 0,71 & 0,09 & 0,05 \\
\hline & & Médio & 2,47 & 1,33 & 0,314 \\
\hline & & Máximo & 4,23 & 2,57 & 0,578 \\
\hline
\end{tabular}

Observa-se que, para o município de Florianópolis, o índice de vazios (e) ficou compreendido entre 2,087 e 4,5. Nas demais regiões de Santa Catarina, esse parâmetro variou entre 0,71 e 8,75. 0 parâmetro Cc para Florianópolis, variou entre 0,54 e 5,0. Para as demais regiões analisadas ficou compreendido entre 0,09 e 3,12. O parâmetro CR, em Florianópolis variou entre 0,1 e 0,531 e em todas as outras regiões encontra-se entre o intervalo de 0,05 e 0,578.

Para que fosse possível calcular o recalque em unidades geotécnicas sedimentares de Florianópolis a partir dos dados disponíveis (SPT e aqueles compilados no bando de dados), buscou-se relacionar o índice 
de vazios $(e)$, o Cc e o CR à outros parâmetros dos solos desse município. Sendo assim, foram elaboradas as equações de correlação apresentadas na Tabela 4 com o seu respectivo $r^{2}$ e o número de dados empregados na sua elaboração.

Tabela 4 - Equações de correlação entre os dados do banco de dados do município de Florianópolis.

\begin{tabular}{|c|c|c|c|c|c|}
\hline Equação & $r^{2}$ & $\begin{array}{l}\text { Número de } \\
\text { dados }\end{array}$ & Equação & $r^{2}$ & $\begin{array}{c}\text { Número de } \\
\text { dados }\end{array}$ \\
\hline$e=0,0231 w+0,3329$ & 0,99 & 16 & $C c=-0,1273 \gamma+3,0643$ & 0,04 & 20 \\
\hline$e=0,4317 C R+2,6129$ & 0,01 & 16 & $C c=0,0018 C v+0,8143$ & 0,02 & 8 \\
\hline$e=0,0149 L L+1,9332$ & 0,50 & 16 & $C c=0,4463 e+0,0507$ & 0,34 & 16 \\
\hline$e=0,0226 I P+1,6706$ & 0,60 & 16 & $C R=0,0019 L L+0,19$ & 0,52 & 19 \\
\hline$e=-1,4628 Y+23,906$ & 0,90 & 16 & $C R=0,002 I P+0,2526$ & 0,15 & 19 \\
\hline$e=0,0067 C v+3,2224$ & 0,33 & 8 & $C R=-0,00005 C V+0,3237$ & 0,00 & 8 \\
\hline$e=0,7662 C c+1,7762$ & 0,34 & 16 & $C R=-0,0008 w+0,4177$ & 0,04 & 20 \\
\hline$C_{c}=0,0052 w+0,6922$ & 0,11 & 20 & $C R=0,0349 Y-0,1717$ & 0,04 & 20 \\
\hline$C c=3,1459 C R+0,1689$ & 0,69 & 20 & $C R=0,2194 C c+0,0663$ & 0,69 & 20 \\
\hline$C c=0,0067 L L+0,689$ & 0,43 & 19 & $C R=0,0146 e+0,2965$ & 0,10 & 16 \\
\hline$C c=0,0138 I P+0,6043$ & 0,46 & 19 & & & \\
\hline
\end{tabular}

Em relação ao $\mathrm{r}^{2}$, notou-se que determinados parâmetros dos solos não apresentaram correlação $\left(\mathrm{r}^{2}\right.$ igual 0 ) ou apresentaram coeficientes entre 0,01 e 0,50. Nesse estudo não foi encontrada relação entre a razão de compressão (CR) e o coeficiente de adensamento (Cv). Dentre as vinte e uma equações elaboradas, seis parâmetros ao serem relacionados apresentaram coeficientes superiores a 0,5, mostrando-se adequadas de acordo com Karunaprema e Edirisingh (2005 apud HIGASHI, 2006). Foram obtidas equações com $\mathrm{r}^{2}$ superior a 0,5 para os três parâmetros de interesse: $e$, Cc e CR.

De uma forma geral, as relações envolvendo o índice de vazios $(e)$ apresentaram coeficientes de correlação mais altos, quando comparadas aqueles obtidos para o Cc e para o CR. Ao relacionar o índice de vazios $(e)$ com a umidade $(\mathrm{w})$ e com o peso específico $(\gamma)$ foram identificados $\mathrm{r}^{2}$ próximos a 1 (igual e superior a $0,90)$. Encontrou-se, entretanto, uma maior relação entre o índice de vazios $(e)$ e a w $\left(\mathrm{r}^{2}\right.$ igual 0,99$)$. Como pode ser observado na Figura 2 outros autores também encontraram relações próximos a 1 para os parâmetros mencionados.

Figura 2. Relação entre o índice de vazios (e) e a umidade (w) para diferentes autores.

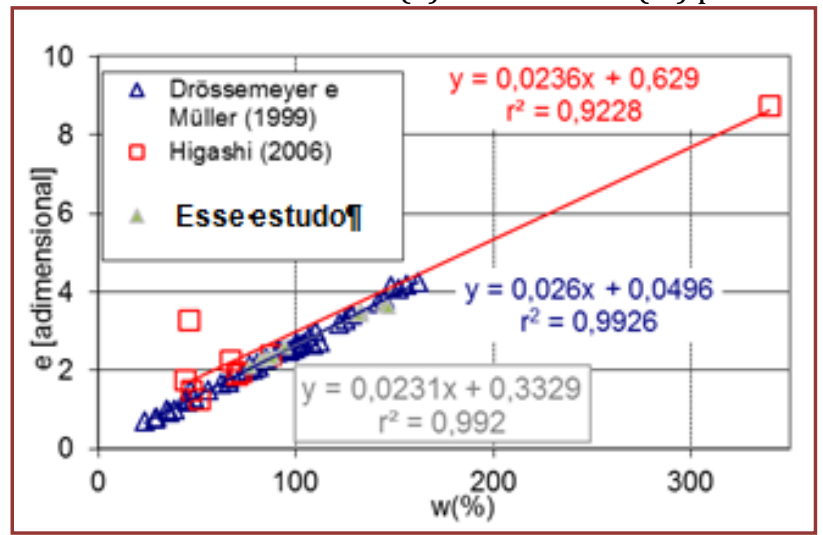

Em relação as sondagens SPT selecionadas para os cálculos do recalque, a Tabela 5 apresenta o número de perfis analisados em cada uma das cinco unidade geotécnicas sedimentares em estudo. Até a profundidade de $4 \mathrm{~m}$, foram identificados perfis de solos argilosos de consistência mole a muito mole, cuja granulometria variou entre argila e argila com silte, com areia, com detritos vegetais, matéria orgânica e fósseis marinhos. Além de argilas, ocorreram em determinados SPT, nos extremos dos perfis (acima ou abaixo da camada compressível) camadas de areia fina a grossa, areia com argila, areia com silte e silte com areia, onde o recalque não foi calculado uma vez que a equação utilizada nesse estudo (equação 1) não se aplica para esse tipo de solo. 
Tabela 5 - Quantidade de SPT em cada unidade geotécnica.

\begin{tabular}{|c|c|}
\hline Unidade Geotécnica & Quantidade de perfis \\
\hline AQsq1 & 5 \\
\hline Cde & 7 \\
\hline DNsq & 7 \\
\hline PZsq & 2 \\
\hline Gsq & 1 \\
\hline
\end{tabular}

Para cada um dos perfis de solo selecionados foi determinado a espessura da camada compressível (H), o peso específico das camadas $(\gamma)$, a partir do NSPT, a tensão efetiva inicial $\left(\sigma_{i}^{\prime}\right)$, a tensão efetiva final ( $\sigma^{\prime}$ f), o índice de vazios $(e)$ e o coeficiente de compressibilidade (Cc), para então ser estimado o recalque $(\rho)$ devido ao carregamento imposto por uma sapata tipo $\left(17,78 \mathrm{kN} / \mathrm{m}^{2}\right)$. Os resultados obtidos por unidade geotécnica são apresentados na Tabela 6.

Tabela 6 - Resultados de $\gamma, \mathrm{H}, \mathrm{e}, \mathrm{Cc}, \sigma_{\mathrm{i}}^{\prime}, \sigma_{\mathrm{f}}^{\prime} \mathrm{e} \rho$ para as unidades geotécnicas analisadas.

\begin{tabular}{|c|c|c|c|c|c|c|c|c|}
\hline $\begin{array}{l}\text { Unid. } \\
\text { Geotéc. }\end{array}$ & $\gamma_{\arg }\left[\mathrm{kN} / \mathrm{m}^{3}\right]$ & $\mathrm{H}[\mathrm{m}]$ & $e$ & Cc & $\sigma_{i}^{\prime}\left[\mathrm{kN} / \mathrm{m}^{2}\right]$ & $\sigma_{\mathrm{f}}^{\prime}\left[\mathrm{kN} / \mathrm{m}^{2}\right]$ & $\rho[\mathrm{mm}]$ & $\rho$ médio $[\mathrm{mm}]$ \\
\hline \multirow{5}{*}{ AQsq1 } & 15 & 1,0 & 1,96 & 0,54 & 39,50 & 57,28 & 30 & \multirow{5}{*}{118,00} \\
\hline & 13 & 1,0 & 4,89 & 1,66 & 14,50 & 32,28 & 100 & \\
\hline & 13 & 2,0 & 4,89 & 1,66 & 16,00 & 33,78 & 180 & \\
\hline & 13 & 2,0 & 4,89 & 1,66 & 16,00 & 33,78 & 180 & \\
\hline & 13 & 1,0 & 4,89 & 1,66 & 14,50 & 32,28 & 100 & \\
\hline \multirow{7}{*}{ Cde } & 13 & 1,0 & 1,96 & 0,54 & 27,50 & 45,28 & 40 & \multirow{7}{*}{118,60} \\
\hline & 13 & 3,0 & 4,89 & 1,66 & 17,50 & 35,28 & 260 & \\
\hline & 13 & 1,0 & 4,89 & 1,66 & 38,50 & 56,28 & 50 & \\
\hline & 15 & 3,0 & 1,96 & 0,54 & 22,50 & 40,28 & 140 & \\
\hline & 15 & 1,0 & 1,96 & 0,54 & 39,50 & 57,28 & 30 & \\
\hline & 13 & 3,0 & 4,89 & 1,66 & 17,50 & 35,28 & 260 & \\
\hline & 13 & 1,0 & 4,89 & 1,66 & 38,50 & 56,28 & 50 & \\
\hline \multirow{7}{*}{ DNsq } & 13 & 1,0 & 4,89 & 1,66 & 14,50 & 32,28 & 100 & \multirow{7}{*}{107,14} \\
\hline & 13 & 2,0 & 4,89 & 1,66 & 31,00 & 48,78 & 110 & \\
\hline & 15 & 2,0 & 1,96 & 0,54 & 33,00 & 50,78 & 70 & \\
\hline & 13 & 1,0 & 4,89 & 1,66 & 38,50 & 56,28 & 50 & \\
\hline & 15 & 1,0 & 1,96 & 0,54 & 17,50 & 35,28 & 60 & \\
\hline & 13 & 1,0 & 4,89 & 1,66 & $14,50^{\prime}$ & 32,28 & 100 & \\
\hline & 13 & 3,0 & 4,89 & 1,66 & 17,50 & 35,28 & 260 & \\
\hline Gsq & 13 & 1,0 & 4,89 & 1,66 & 45,50 & 63,28 & 40 & 40,00 \\
\hline \multirow{2}{*}{ PZsq } & 13 & 3,0 & 4,89 & 1,66 & 17,50 & 35,28 & 257 & \multirow{2}{*}{153,30} \\
\hline & 13 & 1,0 & 4,89 & 1,66 & 38.5 & 56,28 & 50 & \\
\hline
\end{tabular}

Em relação ao índice de vazios (e), observou-se que os valores determinados por correlação (apresentados na Tabela 6) aproximaram-se daqueles encontrados para os solos de Florianópolis. Também encontraram-se dentro do intervalo obtido para os solos das demais regiões de Santa Catarina, da mesma forma que os dois valores calculados para o parâmetro Cc.

Na determinação do recalque, foram identificados os maiores valores (na ordem de $260 \mathrm{~mm}$ ) nas unidades geotécnicas PZsq, DNsq, Cde, em perfis com 3m de camada de solo compressível. Em perfis com 2m de camada de solo compressível o maior recalque ocorreu na unidade AQsq1 (180mm). Em 1m de camada de solo compressível nas unidades AQsq1 e DNsq, na ordem de 100mm. De uma forma geral, com exceção da unidade Gsq, as demais unidades apresentaram na estimativa do recalque (em pelo menos um perfil analisado) valores superiores ao limite recomendado em Cintra et al. (2011), que, para sapatas isoladas, corresponde a $65 \mathrm{~mm}$.

\section{CONCLUSÕES}

Realizou-se nesse estudo a compilação de um banco de dados georreferenciado contendo parâmetros físicos e de compressibilidade de solos moles presentes nas regiões litorâneas do estado de Santa Catarina, especialmente em Florianópolis, para gerar equações de correlação que possibilitassem a estimativa do 
recalque a partir de dados de sondagens SPT. Com isso, foram geradas equações com coeficientes de correlação $\left(\mathrm{r}^{2}\right)$ satisfatórios, que podem ser utilizadas em outros estudos envolvendo solos semelhantes aos solos analisados. É importante destacar que os parâmetros obtidos para o município de Florianópolis utilizando as equações de correlação (índice de vazios e coeficiente de compressibilidade) apresentaram valores aproximados àqueles das demais regiões do estado de Santa Catarina determinados a partir de ensaios. No entanto, salienta-se a necessidade da realização de ensaios, principalmente em estudos ou projetos que não são preliminares, para a verificação dos resultados obtidos por meio das equações de correlação.

Os recalques estimados até a profundidade de $4 \mathrm{~m}$, a partir da metodologia proposta neste estudo, possibilitaram a estimativa do comportamento de compressibilidade dos solos presentes em unidades geotécnicas sedimentares do município de Florianópolis, caracterizando-as de forma espacial. Foram analisadas as seguintes unidades individualizadas no mapa geotécnico da Ilha de Santa Catarina: Areias Quartzosas Hidromórficas com substrato sedimentos quaternários (AQsq1), Cambissolo com substrato depósito de encosta (Cde), Dunas com substrato sedimentos quaternários (DNsq), Solo PodzolHidromórfico com substrato sedimentos quaternários (PZsq) e Glei com substrato sedimentos quaternários (Gsq).

Com exceção da unidade Gsq, as demais apresentaram em função do carregamento imposto por uma sapata isolada, recalques superiores a $65 \mathrm{~mm}$ (limite recomendado em CINTRA et al, 2001), em pelo menos um perfil investigado. Em perfis presentes nas unidades PZsq, DNsq, Cde foram obtidos recalques na ordem $260 \mathrm{~mm}$, valor máximo estimado para a área de estudos. Entretanto, a unidade PZsq foi a que apresentou a maior média de recalque (valor médio estimado em 153,30mm). Dessa forma, os solos presentes nessas unidades foram caracterizados em termos de ocorrência de recalque por adensamento primário, identificando aqueles onde a sua ocorrência é mais crítica e pode vim a representar um problema para o uso e ocupação do solo, auxiliando no planejamento do processo de expansão urbana.

\section{AGRADECIMENTOS}

Os autores agradecem ao Laboratório de Mapeamento Geotécnico (LAMGEO) do Departamento de Engenharia Civil da UFSC, ao Programa de Pós-graduação em Engenharia Civil da UFSC (PPGEC), à Coordenação de Aperfeiçoamento de Pessoal de Nível Superior (CAPES) e ao Conselho Nacional de Pesquisa (CNPQ).

\section{REFERÊNCIAS}

[1] Associação Brasileira De Normas Técnicas. NBR 7250 (1982) "Identificação e descrição de amostras de solos obtidas em sondagens de simples reconhecimento dos solos”, Rio de Janeiro: ABNT.

[2] Associação Brasileira De Normas Técnicas. NBR 6122 (1986) “Solo - Projeto de execução de fundações", Rio de Janeiro: ABNT.

[3] Associação Brasileira De Normas Técnicas. NBR 12007 (1990) "Solo - Ensaio de adensamento unidimensional", Rio de Janeiro: ABNT.

[4] Baran, K. R. (2014) "Propriedades Geotécnicas de Compressibilidade de uma Argila Mole de Itajaí-SC", Universidade Federal de Santa Catarina.

[5] Bastos, C. A. B. et al (2004) "Mapeamento Geotécnico como Subsídio ao Monitoramento e Previsão de Riscos Geotécnicos em Obra de Tubulação de Gás Natural" in 5o Simpósio Brasileiro de Cartografia Geotécnica e Geoambiental, Anais, São Carlos, SP, v.1.

[6] Carvalho, N. F. (2000) “Características geotécnicas da argila mole da rodovia BR 101 em Santa Catarina”, 127 f. Dissertação de Mestrado, Puc-Rio, Rio de Janeiro.

Cintra, et al. (2011) "Fundações diretas: projetos geotécnicos", São Paulo: Oficina de Textos.

[7] Coutinho, R. Q.; Oliveira, J. T. R. "Propriedades geotécnicas das argilas moles do Recife” in: X Cobramseg, Foz de Iguaçu, PR, ABMS. Anais, Vol 2. 0. 563-572.

[8] Das, B. M. (2013) "Fundamentos de Engenharia Geotécnica”, 7. ed. ed. São Paulo: Cengage Learning.

[9] Davison Dias, R. (1995) "Proposta de metodologia de definição de carta geotécnica básica em regiões tropicais e subtropicais" in: Revista do Instituto Geológico, São Paulo, SP, p.51-55. 
[10] Drösemeyer. A., et al. (1999) “Estudo de Correlações entre índices físicos e parâmetros de compressibilidade e resistência dos depósitos de solos moles da Rodovia BR-101” 82p. Monografia (Trabalho de Conclusão de Curso) Universidade Federal de Santa Catarina-UFSC.

[11] Espindola, M. Da S. (2011) "Análise dos parâmetros geotécnicos dos solos moles da obra de ampliação do Aeroporto Internacional Hercílio Luz”, Universidade Federal de Santa Catarina.

[12] Guesser, L. H. (2013) "Elaboração do Mapa Geotécnico Preliminar e Mapa de Áreas Suscetíveis a Movimentos de Massa do Município de Antônio Carlos-SC", Trabalho de Conclusão de Curso, Graduação em Engenharia Civil na Universidade Federal de Santa Catarina, 1747p.

[13] Higashi, R. A. Dos R. (2006) "Metodologia de Uso e Ocupação dos Solos de Cidades Costeiras Brasileiras Através de SIG com Base no Comportamento Geotécnico e Ambiental”,Universidade Federal de Santa Catarina.

[14] Isoppo, A. et al (2013) "Estruturação e Utilização de um Banco de Dados Geotécnico da Ilha de Santa Catarina em SIG", Trabalho de Conclusão de Curso, Graduação em Engenharia Civil na Universidade Federal de Santa Catarina, 83p.

[15] Massocco, N. S. (2013) "Determinação de Parâmetros de Compressibilidade e de Resistência não Drenada de Argila Mole - Estudo de Caso.", Florianópolis.

[16] Morettin, P. A., et al. (2012) “Estatística Básica”, 7. ed. ed. São Paulo: Saraiva.

[17] Moura, A. P. DE. (2004) "Adensamento com Velocidade Controlada de Deformação (CRS): Desenvolvimento do Equipamento e Realização de Ensaios em Solos Moles do Leste de Santa Catarina”, Universidade Federal de Santa Catarina.

[18] Oliveira, H. M. De. (2006) "Comportamento de Aterros Reforçados Sobre Solos Moles Levados à Ruptura", Universidade Federal do Rio de Janeiro.

[19] Ortigão, J. A. R. (1995) “Introdução à Mecânica dos Solos dos Estados Críticos”,2. ed. ed. Rio de Janeiro: LTC Livros Técnicos e Científicos.

[20] Paredes, E. A. (1994) "Sistema de informação geográfica geoprocessamento: princípios e aplicações" São Paulo: Erica. 675p

[21] Pinto, C. De S. (2000) “Curso Básico de Mecânica dos Solos”, São Paulo: Oficina de Textos.

[22] Santos, G. T. (1997) "Integração de informações pedológicas, geológicas e geotécnicas aplicadas ao uso do solo urbano em obras de engenharia", Tese (doutorado) em Engenharia de Minas, Metalúrgica e Materiais, Universidade Federal do Rio Grande do Sul.

[23] Teixeira, A. H., et al.(1998) "Análise, projeto e execução de fundações rasas” in: W. Hachich; F. F. Falconi; J. L. Saes; et al. (Orgs.); Fundações Teoria e Prática. Pini ed., p.762.

[24] Telissari. L.S. (2011) "Estudo do Comportamento de Aterro sobre Solo Mole - Estudo de Caso - Aeroporto de Joinville.”, Trabalho de Conclusão de Curso (Engenharia Civil) Universidade do Vale do Itajaí. Itajaí, SC.

[25] Yuaça, F. (2003) “Tutorial GIS para prefeituras”, 40p. 


\section{Capítulo 4}

\section{Comportamento de ancoragens protendidas com redução de fases de injeção}

\section{Rodrigo Rogério Cerqueira da Silva}

Resumo: Uma das grandes dificuldades relacionadas a projetos de obras de contenção através da utilização de ancoragens protendidas está na determinação da capacidade de carga dos tirantes relacionados aos critérios de reinjeção. As propriedades geotécnicas utilizadas em projeto nem sempre representam a realidade para o tipo de solo da região trabalhada, tornando-se imprecisas a quantidade de cimento injetada. A transferência de carga solo-bulbo, em obras de contenções são dimensionadas por metodologias que não se enquadram na realidade dos parâmetros do solo in loco, tornando-se imprescindível a realização de ensaios em tirantes para comprovação de seu desempenho e quanto ao atendimento das especificações de projeto. Este estudo tem como objetivo analisar a capacidade de carga em ancoragens protendidas de uma cortina atirantada através do número de fases de injeção, localizadas em uma obra de estabilidade de encosta no município de São Miguel Arcanjo sudoeste de São Paulo. Em função das características do maciço, as ancoragens feitas através de cordoalhas de aço, foram avaliadas através das pressões de injeções de acordo com a resistência do solo e do número de reinjeções, verificando seu desempenho de acordo com ensaios de recebimento conforme a norma NBR 5629 (2006). Avaliando que para cada tipo de solo e para cada tipo de trabalho a ser efetuado existe um limite de injetabilidade, sendo que o melhor limite deverá ser compatível com as resistências mecânicas do solo ao qual o tirante será executado, demonstrando que a injeção em única fase pode ser adotada para maciços com alta capacidade de suporte, viabilizando através dos números de injeções a relação técnicaeconômica da obra.

Palavras-Chave:Tirantes, injeção de calda, estabilização de encostas, ensaio qualificação. 


\section{INTRODUÇÃO}

Uma das maiores dificuldades para o emprego de técnicas de contenção para garantir a estabilização de taludes e escavações é apresentar uma alternativa técnico-econômica viável, entretanto, devido às condições específicas às quais elas foram elaboradas nem sempre os resultados representam a realidade para o tipo de solo da região analisada, tornando-se os custos elevados. A escolha da contenção a ser executada em uma encosta deve levar em conta os aspectos geotécnicos, dimensões da encosta, eficácia da técnica escolhida e principalmente os custos. Obras envolvidas por grandes movimentações de solo, muitas vezes utilizam métodos de contenção que envolve a aplicação de ancoragens através da utilização de tirantes.

Apesar do largo emprego desta técnica no Brasil, existe um número restrito de pesquisas realizadas sobre o método de execução e estabelecer a quantidade injetada de calda de cimento por fase em cada válvula manchete. É claro que fica difícil para um Engenheiro Projetista projetar um serviço artesanal, porém, uma vez estabelecido o princípio filosófico, pode-se estabelecer parâmetros básicos de projeto, tendo em vista experiências anteriores, fica fácil estimar a zona tratada, o espaçamento entre os furos, as distâncias entre as válvulas e as quantidades e pressões por vez ou fase (GUIMARÃES FILHO, 1984).

Estudos realizados por Porto (2015) e Silva e Pereira (2016) demonstraram que a estabilidade de uma contenção com utilização de ancoragens é estudada em seu estado limite, sendo o mecanismo responsável pela transferência de carga e restrição do movimento do maciço de solo, é a resistência ao cisalhamento (qs) e capacidade de carga. A estimativa mais aproximada da resistência ao cisalhamento de tirantes em solo é obtido através de formulações semi-empíricas disponíveis na literatura Ostermayer e Scheele (1977), Bustamante e Doix (1985), Costa Nunes (1987), Souza (2001), NBR 5629 (2006) e Porto (2015). Percebe-se que as obras de contenções especiais no Brasil são dimensionadas muitas vezes por metodologias que não se adequam satisfatoriamente com a realidade do solo nacional, ocasionando projetos que não cumprem o paradigma básico da engenharia que é: "possibilitar a execução de obras econômicas e seguras" (PORTO e GOMES 2016).

0 verdadeiro comportamento reológico das ancoragens é obtido através de ensaios precedentes a execução dos tirantes, a partir de ensaios de recebimento, qualificação e/ou básico estabelecidos pela NBR 5629 (2006). A metodologia de execução, tipo de tirante, diâmetro do furo, fator água/cimento, tempo de execução, metodologia de injeção e volume injetado, representam a realidade do comportamento das ancoragens no que se refere a sua capacidade de carga. De acordo com Xanthakos (1991) a protensão deste elemento quando ancorado em uma parte adequada do solo mobiliza uma reação de resistência, cuja carga é transmitida à estrutura de contenção pela parte conhecida como cabeça do tirante, sendo a ancoragem a parte responsável pela transmissão da carga até a cabeça ocorre pelo trecho livre.

0 presente trabalho objetiva realizar através de uma obra de estabilização de encostas por cortina atirantada, a contribuição da verificação do desempenho de tirantes através do volume de injeção de calda de cimento para criar condições de resistência que permitam a sua ancoragem, desconsiderando a necessidade de varias fases de reinjeção, comprovando o seu comportamento mecânico através da interação entre tirante e solo com base nos ensaios de recebimento estabelecidos pela NBR 5629 (2006). Considerando a experiência do executor, o acompanhamento da execução e á análise de instrumentação, elementos condicionantes na definição do projeto para o número de fases de injeção, viabilizando a uma relação técnica-econômica da obra.

\section{CARACTERIZAÇÃO DA OBRA}

A obra localizada no município de São Miguel Arcanjo sudoeste de São Paulo, estendendo-se por 930,34 $\mathrm{km}^{2}$, com altitude média de 660 metros acima do nível do mar, a cortina situa-se nas coordenadas geográficas de $24^{\circ} 02^{\prime} 22^{\prime \prime}$ latitude sul e de $48^{\circ} 00^{\prime} 45^{\prime \prime}$ longitude oeste, realizada dentro do parque ecológico Carlos Botelho (Figura 1). 
Figura 1: Localização da área de estudo.

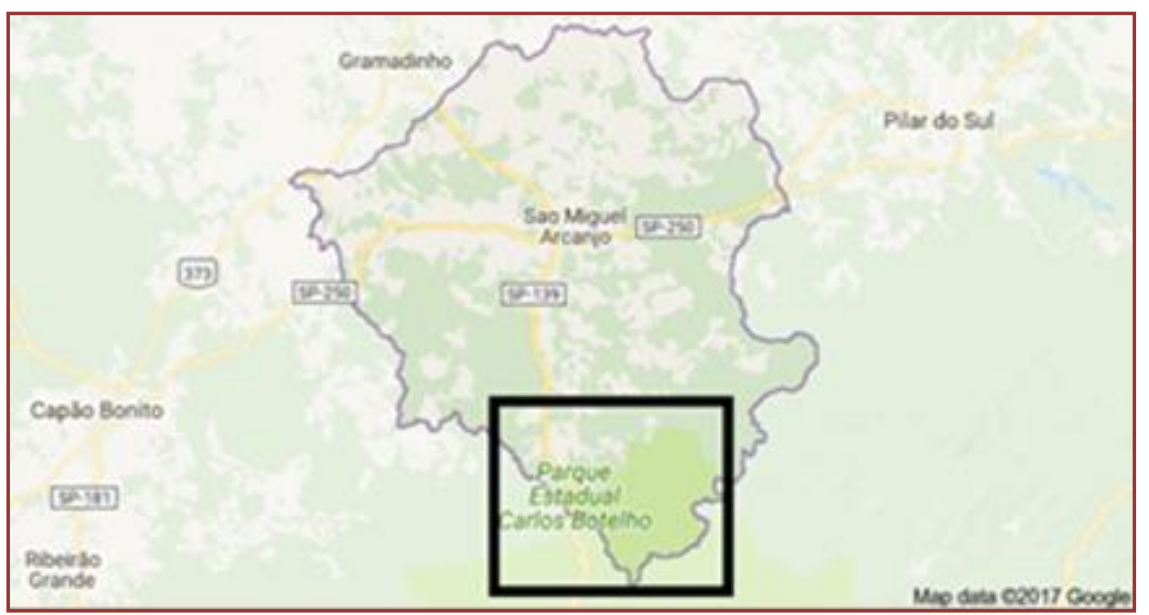

Com uma extensão de $35 \mathrm{~km}$ foi construído junto ao parque ecológico a estrada Parque, com o intuito de assegurar a preservação ambiental e a sustentabilidade da região, porém devido a vários trechos decorrentes de escorregamentos o ecoturismo da região foi prejudicado (Figura 2a), sendo a obra considerada de critério emergencial. A estabilização de encostas foi realizada ao longo da reserva ambiental nos trechos avaliados de riscos, através da técnica de cortina atirantada (Figura $2 \mathrm{~b}$ ) associado a sistema de drenagem.

Figura 2. (a) Vista geral do escorregamento, (b) Vista geral recuperação de encosta com cortina atirantada.

(a)

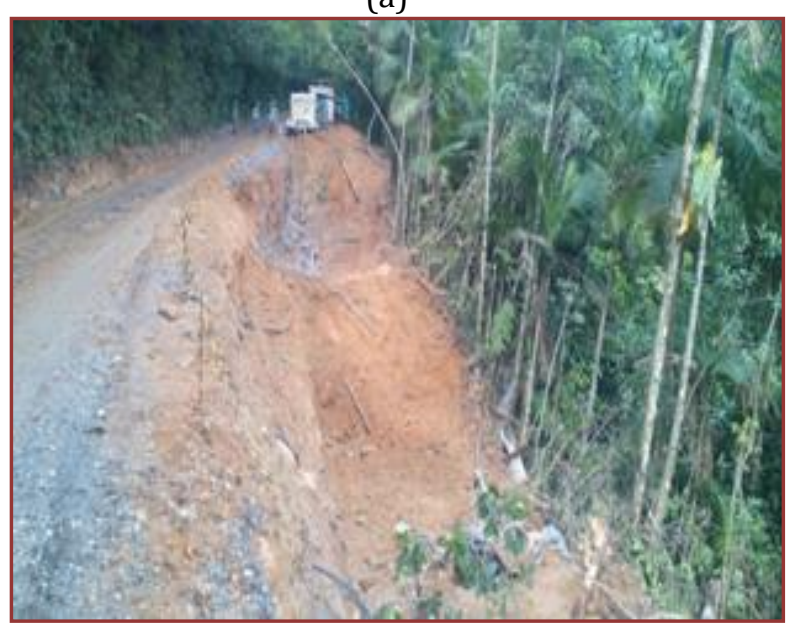

(b)

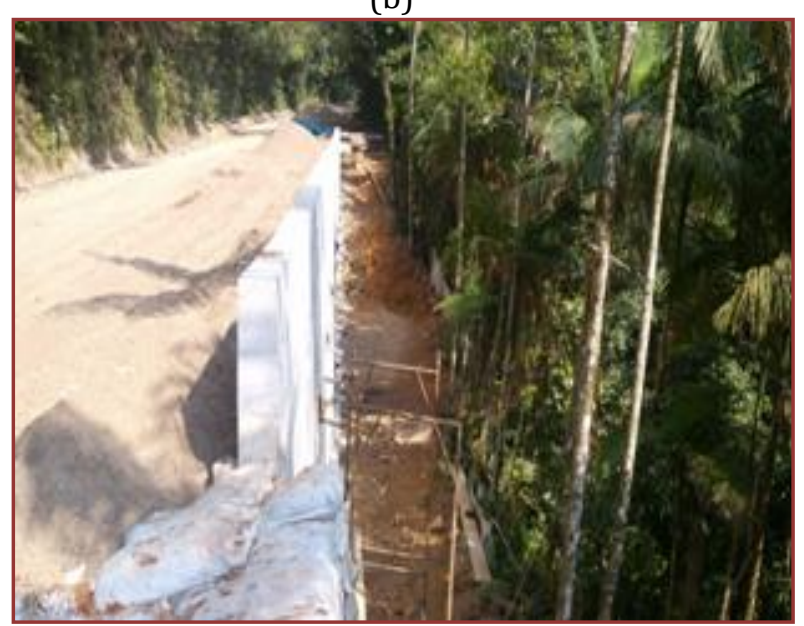

\subsection{CARACTERIZAÇÃO GEOLÓGICA}

A região de São Miguel Arcanjo envolve por completa a área do município a Bacia do Alto do Paranapanema, sendo representado por rochas do Grupo Suíte Granítica Sintectônica, Açungui e PósTectônica, Grupo Itararé e Depósitos Cenozóicos. As rochas do Complexo Pilar do Grupo Açungui acontecem no Sul do município e são representadas por filitos, quartzo filitos e metassiltitos com intercalações subordinadas de micaxistos (PSpF) e quartzitos e por mármores dolomíticos e calcíticos (PSpC) (IPT, 1981).

A Suíte Granítica Sintectônica é representada por rochas da Fácies Cantareira (PSyc) e acontece limitada a uma menor porção no município, em contato e à oeste das rochas do Complexo Pilar. Conforme IPT (1981) expõe corpos para-autóctones e foliados, alóctones, granulação fina a média, textura porfirítica frequente, contatos parcialmente concordantes e composição granodiorítica a granítica. A Suíte Granítica Póstectônica surge reservada a uma área no centro-sul do município, exibindo rochas da Fácies Itu (€Oyi) que 
são corpos graníticos a granodioríticos alóctones, istotropos, granulação fina a grossa, com textura subhipidiomórfica e hipidiomórfica granular (IPT, 1981). As rochas do Grupo Itararé são dominantes na área do município e constituem-se, sobretudo de arenitos com granulação variável, desde fina a conglomerática, argilosos, ocorrendo também pacotes significativos de diamictitos e sedimentos pelíticos, apresentados por siltitos cinza, folhelhos e ritmitos (SAAD, 1977). Têm, ainda, armazéns coluviais que foram colocados entre o Plioceno e o Pleistoceno, que são constituídos por areias com matriz argilosa; cascalhos de limonita e quartzo no alicerce (CBH-SMG, 2000).

\subsection{CARACTERIZAÇÃO GEOTÉCNICA}

O subsolo da área do talude aonde será executado a cortina atirantada está inserido em uma região de colúvio, constituído basicamente de duas unidades do ponto de vista estratigráfico, seguindo um perfil com camada pouco espessa de solo sobreposta a material rochoso.

De acordo com os resultados das sondagens executadas na crista da cortina atirantada, as camadas de solo são constituídas por sucessão alternadas de argila com presença de areia fina e média além de silte pouco arenoso, apresentando espessura média de 2 a 4 metros com $\mathrm{N}_{\mathrm{SPT}}$ variando entre 15 a 25 golpes. Seguido de uma camada de solo de alteração com característica argila arenosa com presença de pedregulhos e matacões, variando entre 4 a 6 metros de espessura com $\mathrm{N}_{\text {SPT }}$ de 25 a 30 golpes, indicando presença de material impenetrável a partir de 6 metros.

A camada pouco espessa de solo residual de São Miguel Arcanjo, em geral é rica em areia fina e média siltosa muito compacta com presença de mica, ou silte argilo-arenoso de consistência duro a muito duro com pedregulhos, a Figura 3 indica as características geológicas locais.

Figura 3: Características geológicas da área de execução da cortina atirantada.
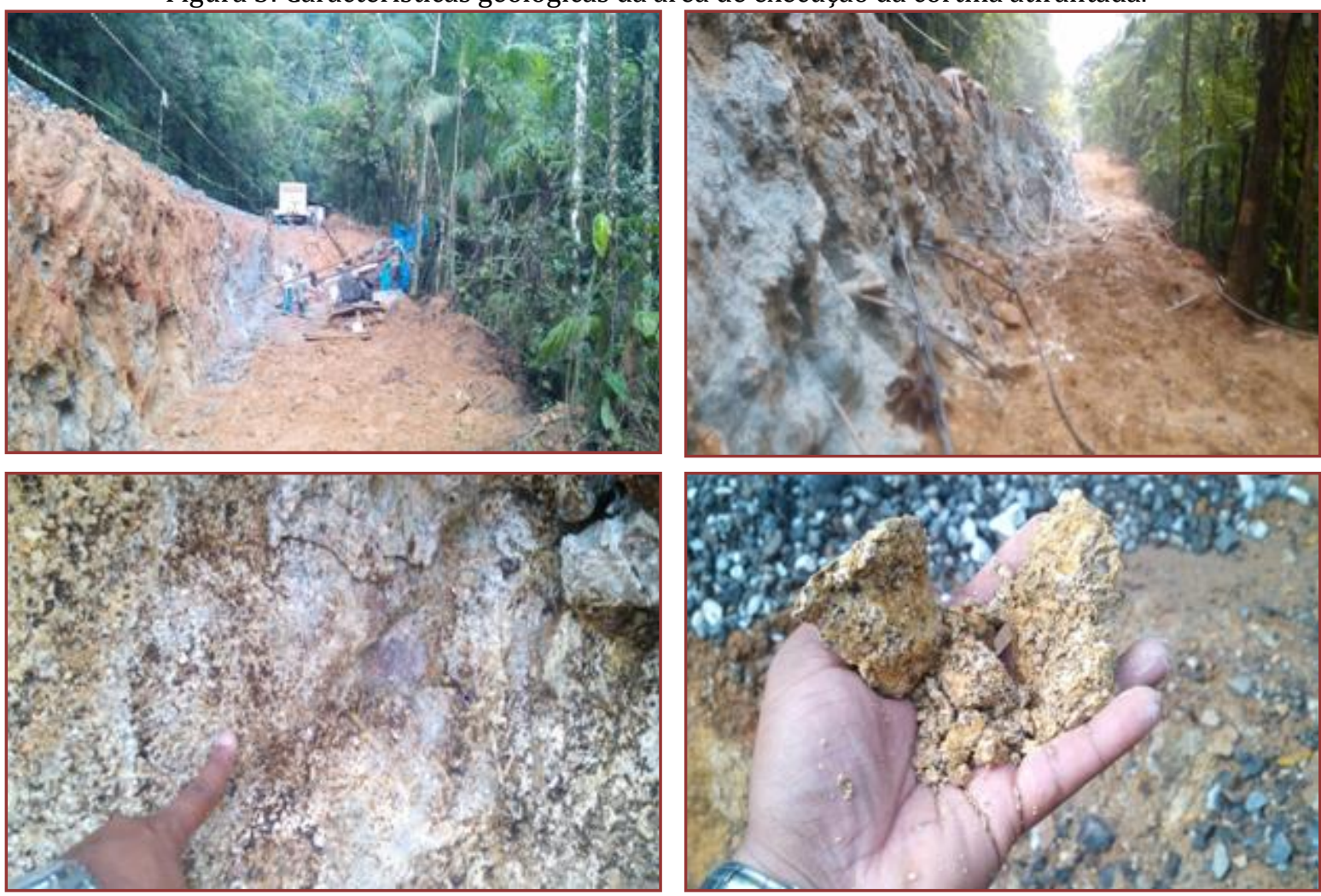


\subsection{EXECUÇÃO CORTINA ATIRANTADA}

Após os escorregamentos foram removidas toda massa de detritos até a camada de solo estável, os tirantes foram executados de forma descendente em duas linhas com inclinação de 15 graus em relação ao lay out final do corte do talude em $90^{\circ}$, e comprimento de $16 \mathrm{~m}$ (Figura $4 \mathrm{a}$ ), sendo $8 \mathrm{~m}$ ancorado e $8 \mathrm{~m}$ livre com 4 cordoalhas de $12,7 \mathrm{~mm}$, com 16 válvulas manchetes no trecho ancorado espaçadas a cada 50 cm (Figura 4b).

A perfuração foi realizada com máquinas apoiadas sobre bermas com $4 \mathrm{~m}$ (Figura 4c), com limpeza do furo através de ar comprimido para evitar seu fechamento e danos ambientais (Figura 4d), pois através da perfuração teste inicial com água ocorreu fechamento do furo contribuindo com o aumento da saturação existente do maciço promovendo escorregamento do talude, impossibilitando a inserção dos tirantes, além da lama gerada durante a perfuração prejudicar o meio ambiente através das nascentes e vegetação nativa.

Figura 4. (a) Linha de tirantes, (b) vista geral detalhe da linha de tirantes, (c) detalhe de máquina apoiada

(a)

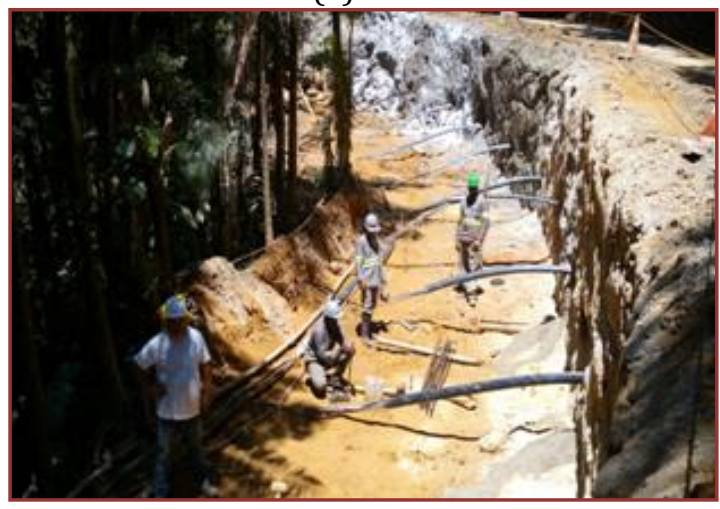

(c)

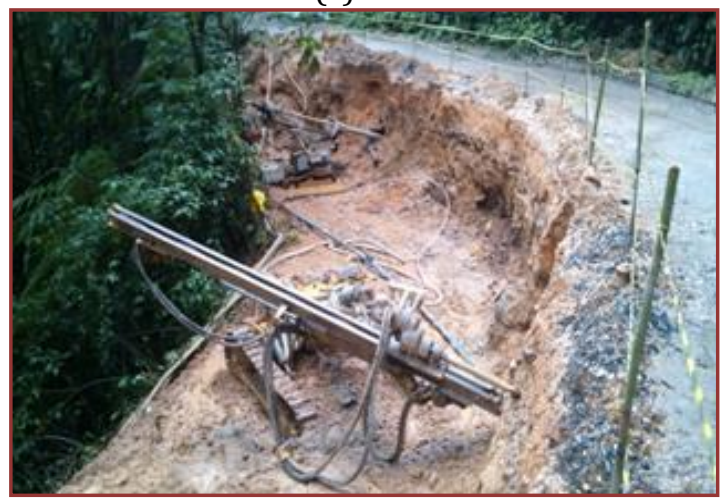

(b)

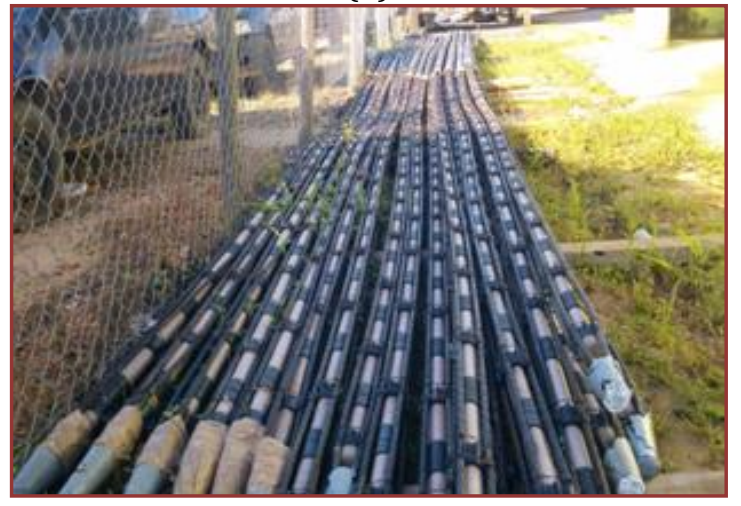

(d)

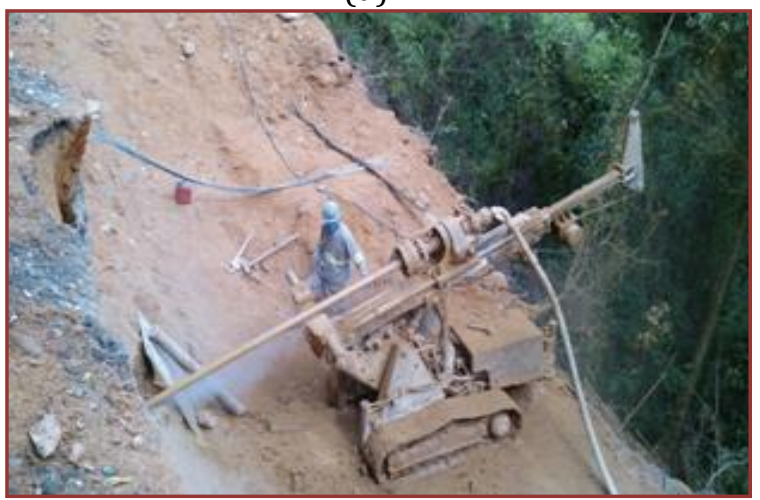

Após a execução dos tirantes foram executadas estacas do tipo raiz como fundação da cortina atirantada (Figura 5a), sendo que a geometria original dos taludes foram mantidas deixando cerca de $3 \mathrm{~m}$ de trecho livre dos tirantes, incorporados durante a concretagem dos painéis (Figura 5b), o sistema de drenagem realizado atrás da cortina foram interligados a barbacãs (Figura 5c), possibilitando a retirada de água do aterro realizado através do lançamento e vibração de areia média grossa para a reconstrução da pista da estrada (Figura 5d), metodologia adotada devido a velocidade na execução do aterro e pela dificuldade para conseguir área de empréstimo de solo na região. 
Figura 5. (a) execução estaca raiz, (b) vista geral dos tirantes incorporados a cortina, (c) detalhe sistema drenagem, (d) geometria da pista reconstituída com areia.

(a)

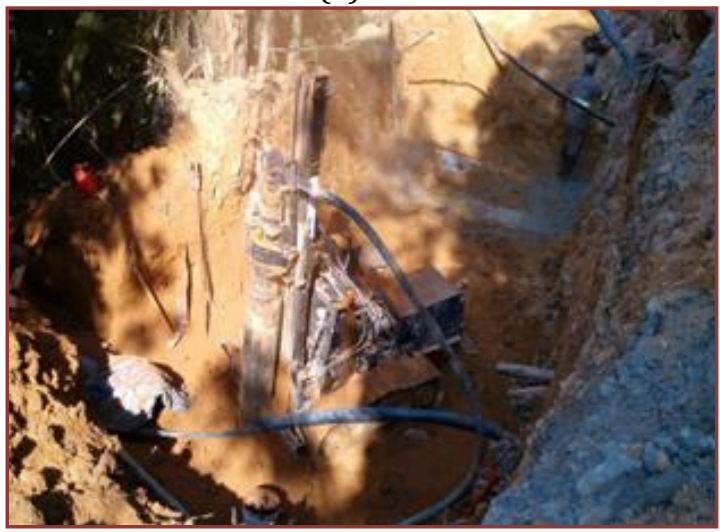

(c)

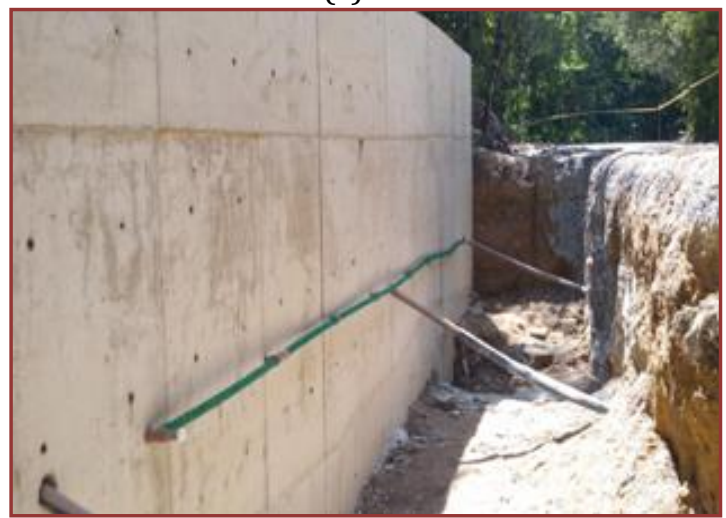

(b)

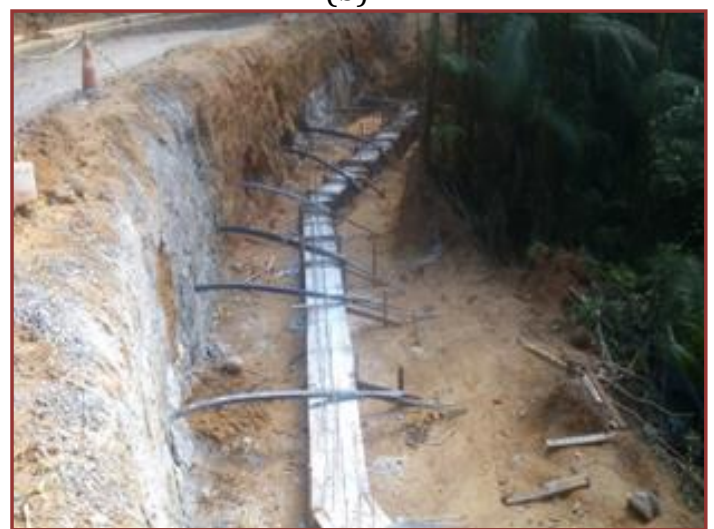

(d)

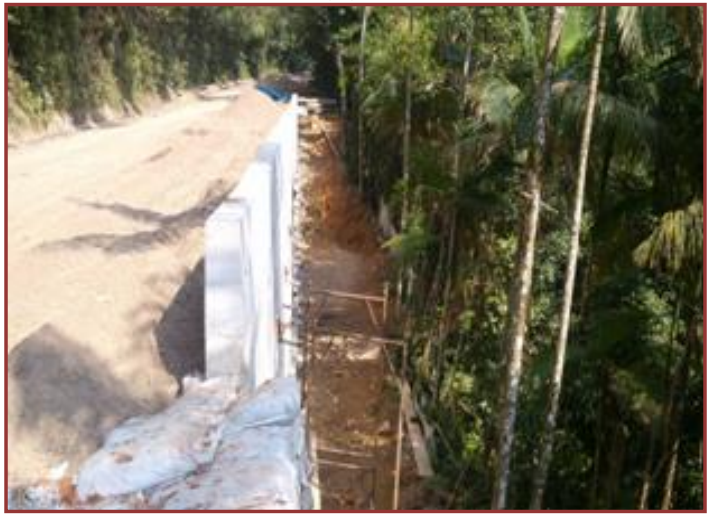

As caldas comumente usadas para execução de tirantes são constituídas basicamente de cimento e água, onde eventualmente para melhorar as suas características de estabilidade e injeção, pode-se adicionar algum tipo de aditivo (acelerador ou retardador) em função das condições climáticas. Ensaios realizados por Silva (2011) demonstram que as caldas de cimento podem variar sua resistência ligeiramente em decorrência das diversas marcas de cimento e tipos de aditivos.

A principal condicionante que afeta as propriedades das injeções é a relação a/c (água/cimento), pois o excesso de água causa exsudação a qual reduz a resistência, aumenta a retração, porosidade e diminui a adesão das ancoragens ao solo. A análise do desempenho da injeção de calda de cimento dos tirantes foram realizadas de acordo com as recomendações de Azevedo et al. (1978) e Silva e Pereira (2016), o qual baseia-se no comportamento geológico do maciço, e através dos procedimentos técnicos como: linhas de injeção, espaçamento entre os furos, pressões de injeção, tipos de calda e critério de recusa da calda de cimento.

Para cada tipo de calda e para cada tipo de trabalho a ser efetuado existe um limite de injetabilidade, capacidade da calda penetrar no meio a ser injetado, sendo que a melhor injetabilidade deverá ser compatível com as resistências mecânicas que a calda deverá oferecer. Conforme Cambefort (1964) a pressão de injeção depende da permeabilidade do terreno, abertura das fissuras, viscosidade caudal e do número de fases que geram um gradiente de pressão. Este gradiente pode ser chamado de "gradiente de melhoria do solo", ou seja, incrementos de capacidade do terreno reagir á pressão com o transcorrer das diversas fases de injeção, em cada ponto.

O bulbo de ancoragem é responsável por interagir com o solo transmitindo o esforço de tração, formado por injeção de calda de cimento sob pressão e fixado ou ancorado na região estável do maciço. De acordo com Porto (2015) a capacidade de carga da ancoragem está intimamente relacionada à geometria, configuração e dimensão do bulbo de ancoragem, elementos com ligação direta a metodologia executiva. 
O tipo de obturador utilizado e pressão de injeção podem gerar bulbos uniformes através de única fase de injeção com baixa pressão ou em formato de raiz com pressão de injeção elevadas e através de reinjeções. As irregularidades e fraturas dos solos faz com que a nata de cimento penetre resultando em alargamento e enraizamento do bulbo, com possível geração de fratura hidráulica em pontos de maior fragilidade. Segundo Yassuda e Dias (1998) a aplicação da pressão da calda para o preenchimento dos vazios, comprime o terreno que circunda o tirante até que haja a ruptura hidráulica do solo, gerando fissuras pelas quais a calda de cimento se infiltrará, no momento que se inicia a infiltração da calda pelas fissuras, há uma queda na pressão devida ao afastamento da calda no solo, tornando desnecessário o prosseguimento do estágio de injeção.

Para a execução das injeções o esquema de preparo da calda de cimento foi realizado através de uma central próxima a área teste, através de misturador de alta turbulência provido de turbina, com rotação mínima de $1.700 \mathrm{rpm}$, capaz de preparar calda de cimento em quantidades suficiente para suprir a bomba injetora fornecendo a homogeneidade adequada à mistura.

A avaliação do número de fases de injeção foi realizada em 21 tirantes, submetidos a injeção de bainha e diferentes fases conforme Tabela (1), com calda fator a/c 0,5 e resistência mecânica a 28 dias com valores entre 25 a 28 Mpa. As pressões de injeção e o volume de calda absorvida para todas as válvulas machetes foram acompanhados através de estabilizador de pressão instalados junto á central de injeção, em função do comportamento da calda quanto à injetabilidade no maciço as pressões de abertura (PA) sofreram variações da ordem de 25 a $45 \mathrm{kgf} / \mathrm{cm}^{2}$, e pressões de injeção (PI) média de $30 \mathrm{kgf} / \mathrm{cm}^{2}$, assim o número de fases de injeção foi realizado conforme a injetabilidade do terreno ao redor das ancoragens, realizadas após um período de 24 horas (Figura 6a). A interrupção da etapa de injeção para cada válvula manchete foi realizada quando os valores da pressão final (PF) superaram os valores de pressão de injeção (PI), possibilitando o desenvolvimento do bulbo de ancoragem (Figura 6b).

Figura 6. (a) Vista geral injeção dos tirantes, (b) Detalhe da pressão de injeção dos tirantes.

(a)

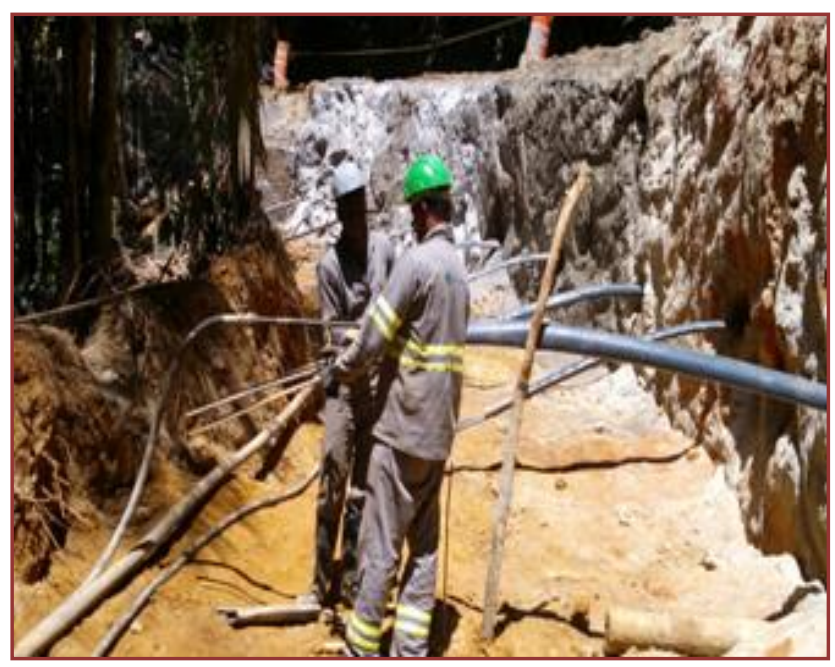

(b)

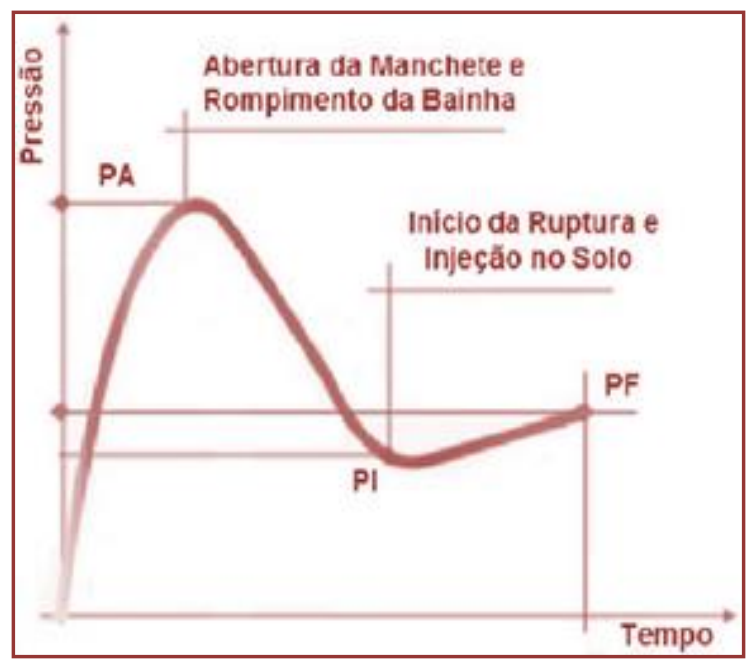

A tabela 1 indica os parâmetros de consumo e pressão verificados in loco durante as injeções.

Tabela 1. Detalhe dos tirantes executados

\begin{tabular}{|c|c|c|c|c|}
\hline $\begin{array}{c}\text { Fases de } \\
\text { injeção }\end{array}$ & $\begin{array}{l}\text { Quantidade } \\
\text { de tirantes }\end{array}$ & $\begin{array}{l}\text { Consumo de } \\
\text { cimento (kg) }\end{array}$ & $\begin{array}{c}\text { Pressão de } \\
\text { abertura }(\mathrm{Pa}) \\
\left(\mathrm{Kgf} / \mathrm{cm}^{2}\right)\end{array}$ & $\begin{array}{c}\text { Pressão de } \\
\text { injeção (Pi) } \\
\left(\mathrm{Kgf} / \mathrm{cm}^{2}\right)\end{array}$ \\
\hline Bainha & 21 & 500 a 600 & 0 & 0 á 5 \\
\hline 1ㅁ Fase & 7 & 1200 a 2400 & 25 & 20 \\
\hline $2^{\mathrm{a}}$ Fase & 7 & 600 a 1200 & 35 & 25 \\
\hline 3a Fase & 7 & 600 a 800 & 45 & 40 \\
\hline
\end{tabular}




\section{ENSAIOS DE CAMPO REALIZADO}

Depois de realizada a última etapa de injeção dos tirantes, aguardado o período de sete dias conforme estipulado pela norma NBR 5629 (2006), foram realizados ensaios de protensão com finalidade de verificar a eficiência na execução do tirante e testar sua aptidão para receber a carga de trabalho $(\mathrm{Ft})$ prevista em projeto.

A finalidade dos ensaios é comprovar seu desempenho quanto ao atendimento das especificações de projeto evitando possíveis situações de riscos na estabilidade de encostas. De acordo com a NBR 5629 (2006), para avaliar a capacidade de carga e comportamento dos tirantes foram realizados ensaios de recebimento com carga máxima de 1,40 (Ft), em uma cortina com 21 tirantes conforme Figura (8 a), com carga de trabalho de $40 \mathrm{tf}$, avaliados em lotes com diferentes fases de injeções conforme indicado na Tabela 1.

O ensaio de recebimento é feito a partir da aplicação de um ciclo de cargas pré-definidas e das leituras dos deslocamentos da cabeça do tirante durante carregamentos e um descarregamento no último estágio do ciclo.

A apresentação e a análise dos ensaios são realizadas após a plotagem de dois gráficos. 0 primeiro gráfico é referente às cargas aplicadas e aos deslocamentos totais e o segundo gráfico representa os deslocamentos divididos em elásticos e permanentes, sendo a aceitação dos tirantes verificados principalmente através dos resultados referentes à carga máxima estabilizada e ao atrito mobilizado no trecho ancorado.

Através dos dados do ensaio de qualificação foram plotados gráficos de cargas x deslocamentos, o deslocamento máximo da cabeça deve estar situado entre as linhas superior e inferior conforme prescreve a norma NBR 5629 (2006) indicado na Figura 8 (b, c, d). Para que os ensaios sejam aceitos, os deslocamentos da cabeça devem ser menores do que $1 \mathrm{~mm}$ em intervalos de 5 minutos para solos arenosos e 10 minutos para solos argilosos, quando aplicada a carga máxima.

Figura 8: (a) Vista geral da cortina de tirantes ensaiados, Ensaios de recebimento tirante: (b) 1모 fase de injeção, (c) 2a fase de injeção, (d) 3a fase de injeção. (a)

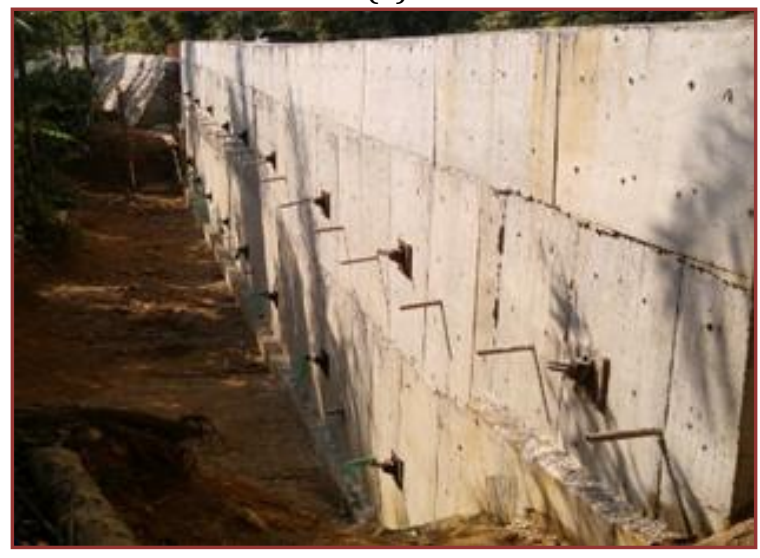

(c)

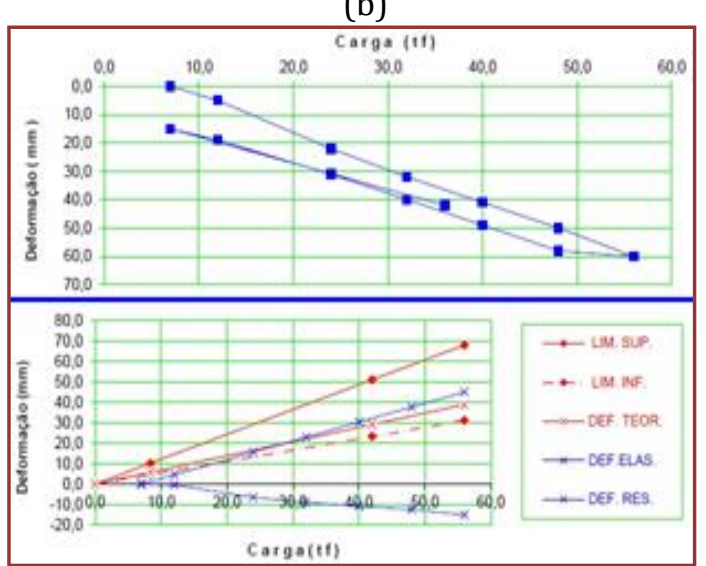

(d) 

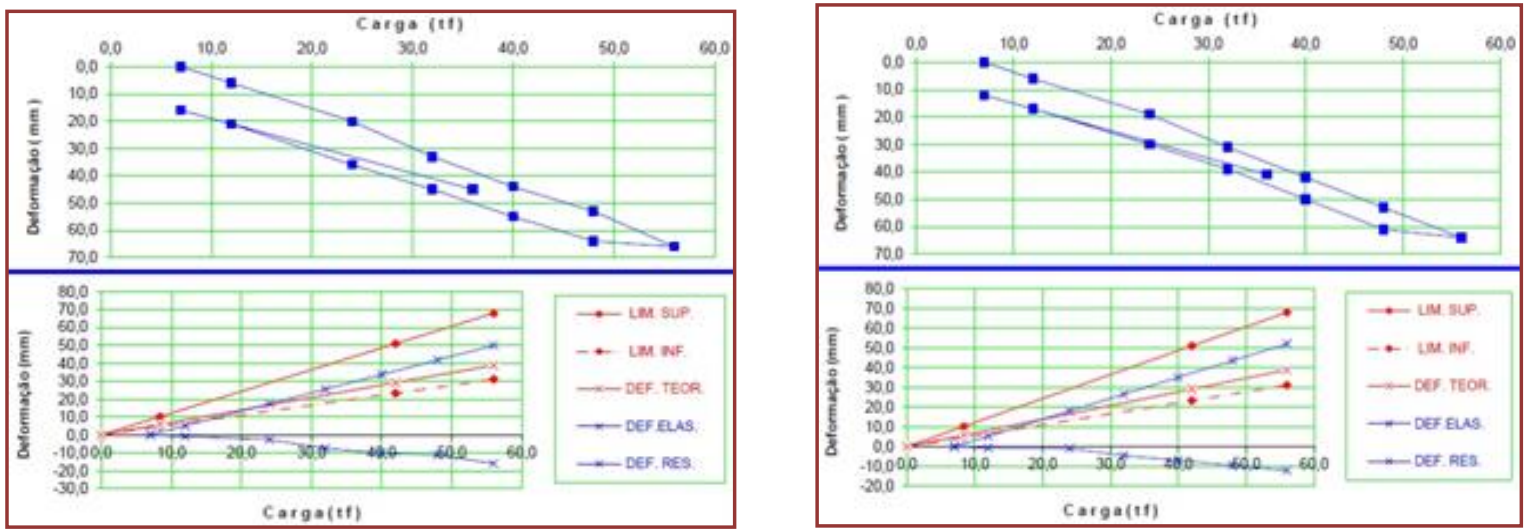

\section{ANÁLISE DOS RESULTADOS}

De acordo com os gráficos obtidos dos ensaios de recebimento, percebe-se que a influência da reinjeção em fases sucessivas para solos de características argilosos e siltosos, indica haver uma influência menos significativa no desempenho dos tirantes executados, com altas pressões e fases sucessivas para solos residuais e/ou alteração com índice de resistência $\mathrm{N}_{\mathrm{SPT}}$ maiores que 20 . De acordo com estudos realizados por More (2003) para solos de consistência ou compacidade mediana são necessários apenas os estágios primários e/ou secundários.

Todos os tirantes injetados com diferentes fases de injeção e consumo de cimento executados na cortina atenderam as recomendações da Norma NBR 5629 (2006), dentro dos limites superior e inferior.

Estudos realizados por Souza (2001) e Porto (2015) alertam que dependendo do tipo de solo, as reinjeções não caracterizam necessariamente aumento da capacidade de carga. De acordo com Silva e Pereira (2016) a melhoria da capacidade de carga através da técnica do incremento do número de injeções, esta relacionada diretamente a solos de baixa resistência como aterro, solos moles e de alta permeabilidade, contribuindo na mudança de seus parâmetros como coesão e atrito.

A determinação do volume de cimento injetado depende das características local o qual baseia-se no comportamento geológico do maciço, e através dos procedimentos técnicos como linhas de injeção, espaçamento entre os furos, pressões de injeção, tipo de traço e critério de recusa da calda de cimento no maciço.

Tratando-se da questão técnico-econômica que envolve o uso de tirantes, este serviço por ser uma atividade especializada necessita que a execução seja feita com materiais, equipes, equipamentos e controle especializados, aumentando os custos das ancoragens. Sendo que através do controle da metodologia de injeção em fases é possível conseguir uma análise da relação custo-benefício, representando uma economia na quantidade de cimento nas obras em cerca $60 \%$, não realizando a $2^{\underline{a}}$ ou $3^{\text {a }}$ fase de injeção para solos de consistência ou compacidade mediana, além de viabilizar o tempo execução contribuindo com o cronograma de obra.

\section{CONSISDERAÇÕES FINAIS}

Os ensaios de qualificação permite verificar a confiabilidade do desempenho dos tirantes após sua execução, além de permitir ajustes de projeto durante a execução. Em função das condições verificadas durante os ensaios e do comportamento da calda quanto à injetabilidade no maciço, as pressões poderão ser reduzidas assim como as fases de injeção conforme a permeabilidade do terreno ao redor da ancoragem.

Para manter a contribuição da técnica de tirantes em taludes de corte, garantindo o seu baixo custo, necessita-se manter as diretrizes de acordo com as características do local, o qual baseia-se no comportamento geológico do maciço e através dos procedimentos técnicos como linhas de injeção, espaçamento entre os furos, pressões de injeção, volumes injetados, tipos de traço de calda e critério de recusa da calda de cimento. 
Os grupos de ensaios realizados possuem uma boa representatividade principalmente para tirantes de cordoalhas executados em solos coesivos com valores de índice de resistência a penetra $\mathrm{N}_{\mathrm{SPT}}$ maior que 20, com controle de injeção com válvulas manchetes espaçadas a cada $50 \mathrm{~cm}$ e injeção com obturador duplo (do fundo do furo para a cabeça do tirante). Demonstrando que para solos de consistência média a rija, as reinjeções não caracterizam necessariamente aumento da capacidade de carga dos tirantes.

\section{REFERÊNCIAS}

[1] Abnt - Associação Brasileira de Normas Técnicas. (2006). NBR 5629 - Execução de Tirantes Ancorados no Terreno. Rio de Janeiro.

[2] Azevedo, A. A. et al. (1978). Injeção de vedação em fundações basálticas de barragens de gravidade. In: Congresso Brasileiro de Geologia de Engenharia, 1978, São Paulo/SP. Anais.São Paulo, v.1, p.17-33.

[3] Bustamante, M.; Doix, B. (1985). Une méthode pour le calcul des tirants et des micropieux injectés. Bulletin de Liaison des Laboratoires des Ponts et Chaussées, Paris, n. 140, p. 75-92.

[4] Cbh-Smg - Comitê da Bacia Hidrográfica do Sapucaí-Mirim/Grande 2000.

[5] Cambefort, H. (1975) Geotechnique de L' Ingenieur. Et reconnaissance de sols. Paris Editions Eyrolles.

[6] Costa Nunes, A. J. (1976). Aplicações geotécnicas da protensão. In: Seminário Nacional do Concreto Protendido, 2. Rio de Janeiro. Anais... Rio de Janeiro: IBS/ABPE.

[7] Guimarães Filho, J. D. (1984) Consolidação de solos por injeção: Discussão sobre uma prática bem sucedida mas que não está de acordo com as teorias clássicas existentes. Revista Solos e Rochas, São Paulo, V. 7, p. 99-107, abril.

[8] Ipt - Instituto de Pesquisas Tecnológicas do Estado de São Paulo. (1981). Mapa Geomorfológico do Estado de São Paulo. São Paulo.

[9] Ostermayer, H.; Scheele, F. (1977). Research on ground anchors in non-cohesive soils. International Conference on Soil Mechanics ans Foundation Engineering, 9. Tokyo. Proceedings... Tokyo: The Japanese Society of Soil Mechanics and Foundation Engineering, 1977. 1 CD-ROM.

[10] Porto, T. B. (2015). Comportamento geotécnico e metodologia via web para previsão e controle. Tese (Doutorado em Geotecnia). Núcleo de Geotecnia, Universidade Federal de Ouro Preto, Ouro Preto.

[11] Porto, T. B., Gomes, R. C. (2016). Proposta de uma formulação simplificada para o cálculo de capacidade de carga de ancoragens. XVIII Congresso Brasileiro de Mecânica dos Solos e Engenharia Geotécnica. COBRAMSEG 2016, Belo Horizonte, Minas Gerais, Brasil.

[12] Saad, A. R., (1977). Estratigrafia do Subgrupo Itararé no centro e sul do Estado de São Paulo. Dissertação. Mestrado, Instituto de Geociências, Universidade de São Paulo.

[13] Silva, R.R.; Pereira, G. A. (2016). Verificação do Desempenho de Chumbadores Realizados com Injeção de Bainha.. IN. XVIII Congresso Brasileiro de Mecânica dos Solos e Engenharia Geotécnica - COBRAMSEG, Belo Horizonte, Minas Gerais, Brasil.

[14] Silva. R. R. (2011). Contribuição para escavação em solo aluvionar através da técnica de injeção de consolidação. In: VI Seminário de Engenharia Geotécnica do Rio Grande do Sul - Geors, Passo Fundo - RS.

[15] Souza, R. N. (2001). Ancoragens reinjetáveis e protendidas em solo: previsão de comportamento e controle de execução. Tese (Doutorado em Engenharia Civil)-Escola Politécnica, Universidade de São Paulo, São Paulo.

[16] Xanthakos, P. P. (1991). Ground Anchors and Anchored Structures. Hoboken, USA: John Wiley\& Sons.

[17] Yassuda, C.T.; DIAS, P. H. V. (1998). Tirantes. In: Hachich, W.; Falconi, F. F.; Saes, J. L.; Frota, R. G. Q.; Carvalho, C. S.; Niyama, S. (Ed.). Fundações: teoria e prática. 2. ed. São Paulo: Pini, p. 603-640. 


\title{
Capítulo 5
}

\section{Correlação entre os sistemas $R M R$ e $Q$ em maciços rochosos da Mina de Volta Grande, Sudeste do Brasil}

\author{
Daniel Silva Jaques \\ Klinger Senra Rezende \\ Eduardo Antonio Gomes Marques
}

Resumo: Este artigo tem por objetivo apresentar uma proposta de correlação entre valores índice de classificação geomecânica de maciços rochosos nos dois sistemas mais difundidos para este propósito - os sistemas RMR, proposto por Bieniwaski em 1973 (atualizado em 1989) e o sistema Q proposto por Barton et al. em 1974 - a partir de resultados obtidos em um estudo maior de caracterização e classificação de maciços rochosos em uma mineração de tântalo localizada no município de Nazareno, Sudeste do Brasil, o qual objetivou a investigação, em fase de pré-viabilidade, do comportamento dos maciços em anfibolito, pegmatito e xisto grafitoso a serem solicitados em projetos de lavra subterrânea. Este estudo demandou a interpretação de 28 furos de sondagem, perfazendo 3473,50 metros lineares de testemunhos, ao longo de seções geológicas previamente estabelecidas. Também foram realizados ensaios mecânicos em rochas para obter parâmetros necessários, sobretudo, à classificação geomecânica pelo sistema RMR. De posse dos valores finais das classificações para cada intervalo de manobra de avanço da perfuração, obteve-se uma equação de correlação entre RMR e Q para estes valores, a qual foi comparada com correlações obtidas por outros autores, nomeadamente as propostas por Bieniawski (1976) e Abad et al. (1983). Verificou-se que a correlação obtida no estudo é moderada a fortemente significativa, apresentando um coeficiente de determinação de 0,71. Quando comparada com as correlações daqueles autores percebeu-se que para valores de $Q$ muito abaixo de 30,0 as correlações propostas tornam-se fracas. Entretanto, para valores de $Q$ muito maiores do que 30,0 as mesmas demonstram uma boa aplicabilidade.

Palavras-Chave: Classificações geomecânicas, correlações, rochas metamórficas, mineração subterrânea 


\section{INTRODUÇÃO}

O objetivo geral deste artigo é apresentar a correlação entre os valores de RMR e Q obtidos em estudo para caracterização e classificação geomecânica dos maciços rochosos da mina de Volta Grande (AMG Mineração), localizada na cidade de Nazareno, Minas Gerais, Brasil. Como objetivo específico o artigo trata de comparar a correlação obtida às correlações de outros autores, analisando a aplicabilidade das mesmas aos dados do referido estudo.

A classificação dos maciços rochosos em classes de semelhante comportamento geomecânico é uma importante ferramenta dentro do campo da geologia de engenharia para investigar as condições dos mesmos antes e depois de serem solicitados em obras tais como mineração subterrânea, construção de túneis, estabilização de taludes. Ainda que seja mais trabalhoso, recomenda-se que a classificação de maciços seja feita utilizando pelo menos dois métodos para refinar os dados e inferir sobre o modelo que melhor se aplica às reais condições (observáveis) dos maciços. Para estes propósitos são comumente utilizados os sistemas de classificações geomecânicas RMR e Q, mundialmente difundidos, desenvolvidos respectivamente por Bienawski em 1973 (aperfeiçoado em 1989) e Barton et. al (1974).

Hoek (2000), lembra muito bem que ao comparar os resultados das classificações RMR e Q é importante considerar que ambos utilizam parâmetros de cunho geológico e geométrico para obter valores quantitativos que resultam na classificação qualitativa dos maciços rochosos. Além disso, em termos de semelhança, ambos consideram a influência da água subterrânea e de algum componente das juntas (preenchimento e rugosidade) influenciando a resistência do material rochoso.

0 mesmo autor ressalta que as principais diferenças entre os sistemas estão nas pontuações dadas aos parâmetros que são semelhantes em ambos, e na utilização de um ou mais parâmetros de projeto diferentes. As principais diferenças, a saber, são:

1] No caso de rochas competentes, o sistema RMR utiliza a resistência à compressão uniaxial diretamente, enquanto o sistema $Q$ trata da resistência in situ;

2] Ambos os sistemas consideram a geologia e a geometria dos maciços rochosos, porém com ligeiras diferenças;

3] A influência da orientação das descontinuidades é um parâmetro direto no sistema RMR, enquanto que no sistema $Q$ isso fica implícito na relação entre $J_{r}$ e $J_{a^{\prime}}$ uma vez que esses parâmetros serão aferidos para a descontinuidade com orientação mais desfavorável;

A maior diferença entre estes sistemas reside no fato de o RMR não possuir um componente diretamente ligado à tensão confinante in situ.

Como lembra Hashemi et al. (2010), à medida que os sistemas de classificação de maciços para engenharia se desenvolve, surge uma questão: se dois sistemas de classificação são usados para projetos em dois locais diferentes, seria possível comparar e relacionar os resultados de ambos? A resposta para este dilema resume-se na tentativa de encontrar uma correlação entre esses sistemas de modo que seja possível estimar um a partir dos dados reais do outro. Nesse sentido, vários autores (Tabela 1) vem apresentando correlações para RMR e Q.

Tabela 1. Correlações entre os sistemas RMR e Q por vários autores (modificado de Laderian \& Abaspoor, 2012).

\begin{tabular}{|c|c|c|}
\hline Autor(es) & Correlação & $\begin{array}{c}\text { Coeficiente de } \\
\text { correlação }\left(\mathrm{R}^{2}\right)\end{array}$ \\
\hline Bieniawski (1976) & $\mathrm{RMR}=9 \ln Q+44$ & 0.77 \\
\hline Rutledge \& Preston (1978) & $\mathrm{RMR}=5.9 \ln Q+43$ & 0.81 \\
\hline Moreno (1980) & $\mathrm{RMR}=5.4 \ln Q+55.2$ & 0.55 \\
\hline Cameron-Clarke \& Budavari (1981) & $\mathrm{RMR}=5 \ln Q+60.8$ & alta dispersão \\
\hline Abad et al. (1984) & $\mathrm{RMR}=10.5 \ln Q+41.8$ & 0.66 \\
\hline Kaiser \& Gale (1985) & $\mathrm{RMR}=8.7 \ln Q+38$ & - \\
\hline Al-Harthi (1993) & $\mathrm{RMR}=9 \ln Q+49$ & - \\
\hline Barton (1995) & $\mathrm{RMR}=15 \ln Q+50$ & - \\
\hline Tugrul (1998) & $\mathrm{RMR}=7 \ln Q+36$ & - \\
\hline Kumar et al. (2004) & $\mathrm{RMR}=6.4 \ln Q+49.6$ & - \\
\hline Hashemi et al. (2010) & $\mathrm{RMR}=5.37 \ln Q+40.48$ & 0.53 \\
\hline Laderian \& Abaspoor (2012) & $\mathrm{RMR}=8.15 \ln Q+44.88$ & 0.85 \\
\hline
\end{tabular}


Correlacionar resultados de dois ou mais atributos significa investigar a sua relação. Ao comparar correlações RMR x Q para os mesmos tipos de trabalhos é possível verificar se os métodos e a percepção entre os estudos foram semelhantes ou não, ou seja, quanto mais próximas as correlações, maiores as chances de que tenham sido empregados os mesmos critérios de obtenção e análise dos dados dos parâmetros necessários para proceder à classificação geomecânica dos maciços. Entretanto, pode-se afirmar, com base no trabalho de Nilsen et al. (2003) que, mesmo que existam equações de correlações, estas podem não ser precisas uma vez que a subjetividade na interpretação e pontuação dos parâmetros destes sistemas é inerente, ou seja, engenheiros com o mesmo tempo de experiência não chegarão a resultados idênticos na classificação de maciços rochosos de um mesmo sítio. Por este mesmo motivo é que equações de correlação obtidas na literatura sempre serão diferentes de autor para autor.

A partir do estudo de 111 casos históricos envolvendo 62 locais na Escandinávia, 28 na África do Sul e mais 21 casos distribuídos entre Estados Unidos, Canadá, Austrália e Europa, Bieniawski (1989) encontrou a seguinte correlação para projetos de túneis em engenharia civil:

$$
\mathrm{RMR}=9 \ln \mathrm{Q}+44
$$

Após a análise de 187 vias de acesso de minas de carvão na Espanha, Abad et al. (1983) chegaram à seguinte correlação para escavações em minas subterrâneas:

$$
\mathrm{RMR}=10,5 \ln Q+42
$$

\section{MÉTODOS}

Para se obter os valores de RMR e Q foi necessário descrever 3473,50 metros lineares de testemunhos de sondagem referentes a 28 furos estrategicamente distribuídos ao longo de seções geológicas previamente estabelecidas em função de sua representatividade geológica dos maciços estudados em profundidade, para a área proposta para a mina subterrânea, sobretudo o corpo pegmatítico de maior interesse para o projeto. Na Figura 1 é possível identificar a alocação dos furos em relação às seções geológicas e à área de estudo.

Figura 1. Área de estudo, como a localização dos furos de sondagem em relação às seções geológicas Norte - Sul (NS) e Leste - Oeste (EW) e ao corpo pegmatítico de interesse.

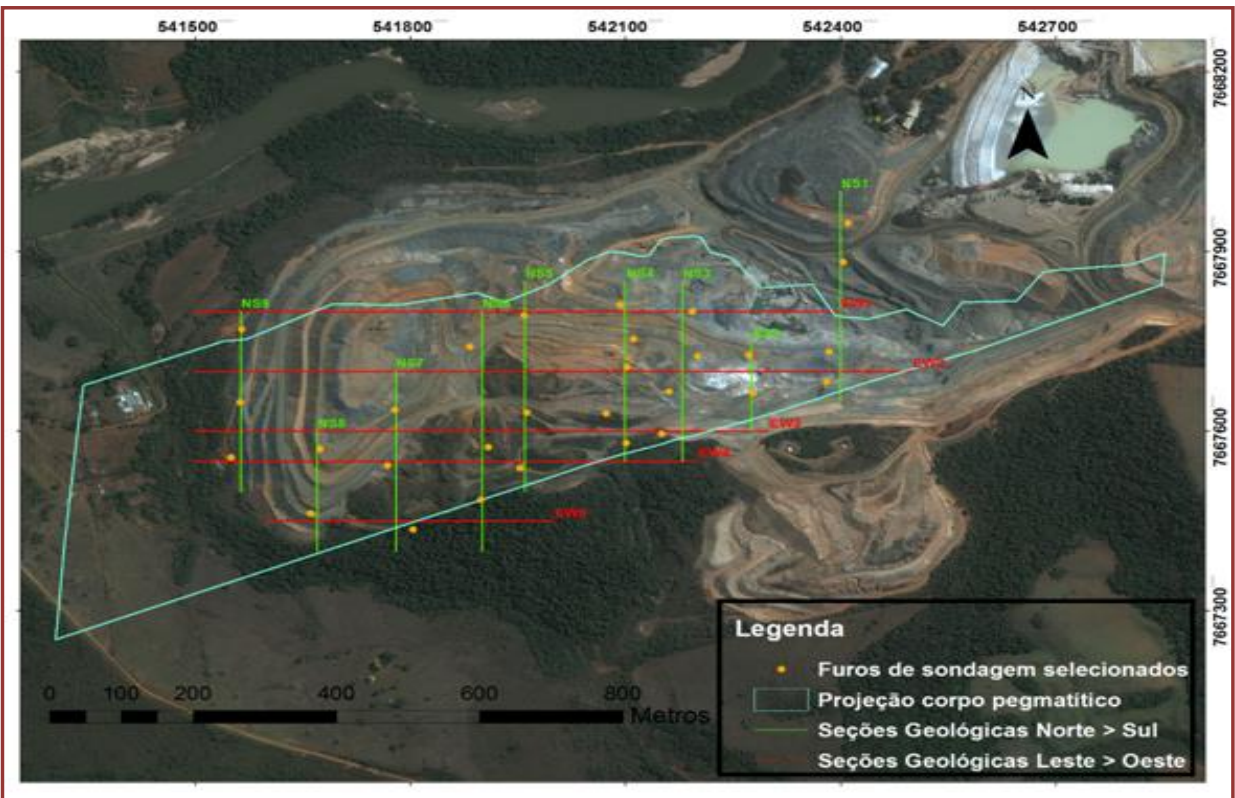


Ensaios de resistência à compressão uniaxial e à carga pontual foram realizados em amostras de rochas dos três litotipos (anfibolito, pegmatito e xisto grafitoso) encontrados na mina em seus diferentes graus de alteração, objetivando caracterizar os maciços e, sobretudo, obter os valores do parâmetro referente à resistência das rochas no sistema RMR. Todos os ensaios foram realizados utilizando-se das metodologias sugeridas pela International Society for Rock Mechanics (ISRM, 2007). Na Figura 2 são apresentados os equipamentos utilizados nos ensaios de resistência das rochas.

Figura 2. Máquinas e seus aparatos, utilizadas nos ensaios: (a) de resistência à compressão uniaxial; (b) de resistência à compressão puntiforme.

(a)

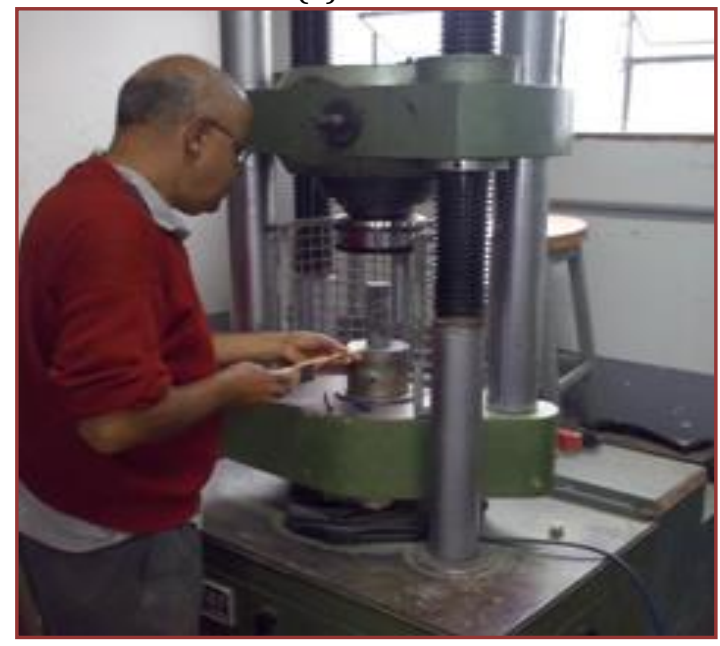

(b)

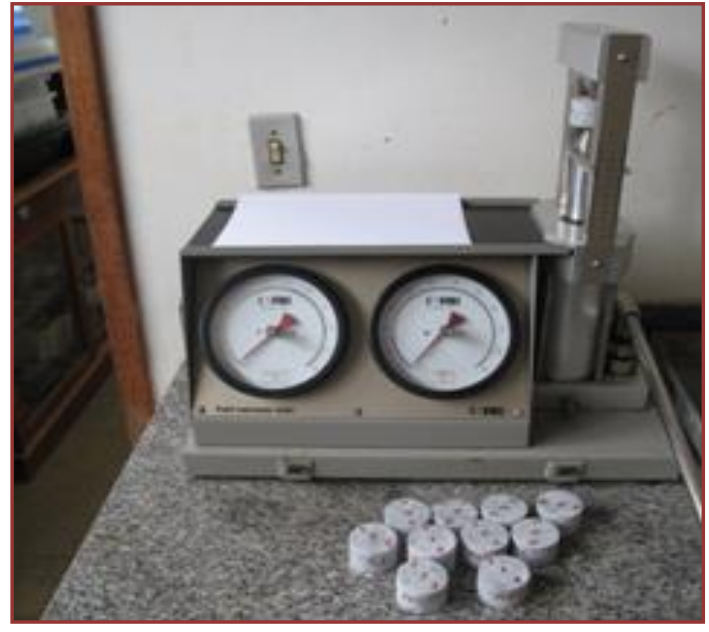

As classes de maciços foram determinadas para cada manobra de avanço da perfuração, as quais tinham, em média, 3 metros. Todos os valores obtidos para cada manobra foram plotados em um gráfico de dispersão dos pares (RMR, Q) a partir do qual obteve-se uma equação de ajuste logarítmico do comportamento dos dados, refletindo a correlação entre eles. Posteriormente, procedeu-se à interpretação do significado da equação obtida e à relação da mesma com as equações propostas por outros autores, verificando-se a aplicabilidade destas últimas ao estudo.

\section{RESULTADOS E DISCUSSÕES}

Para a correlação obtida para os valores índice de RMR e Q, de acordo com o gráfico representado pela Figura 3, é possível afirmar que a mesma se aproxima das correlações propostas por Bieniawski (1976) e por Abad et al. (1983), apresentando um coeficiente de determinação de 0,71, considerado entre moderado e forte, significando que aproximadamente $71 \%$ dos valores de RMR podem ser explicados pela variância de Q (e vice-versa) através da equação de correlação obtida, sendo os 30 \% restantes explicados por outro fatores não relacionados aos dados do estudo.

Para valores do índice Q menores do que 30, principalmente para os valores muito baixos de Q, percebe-se que a correlação resultante do presente estudo superestima o valor de RMR em cerca de 14 a $121 \%$ quando comparada aos valores obtidos pelas correlações de Bieniawski e Abad et al. para a mesma faixa de valores de Q. De maneira a se destacar este resultado apresenta-se, na Tabela 2, a comparação entre valores de RMR obtidos a partir das correlações propostas por aqueles autores e os valores reais de $Q$ e RMR obtidos no presente trabalho para intervalos de alguns dos furos de sondagem analisados. 
Figura 3. Correlação obtida entre RMR e Q, a partir dos dados do estudo, em comparação com as sugeridas

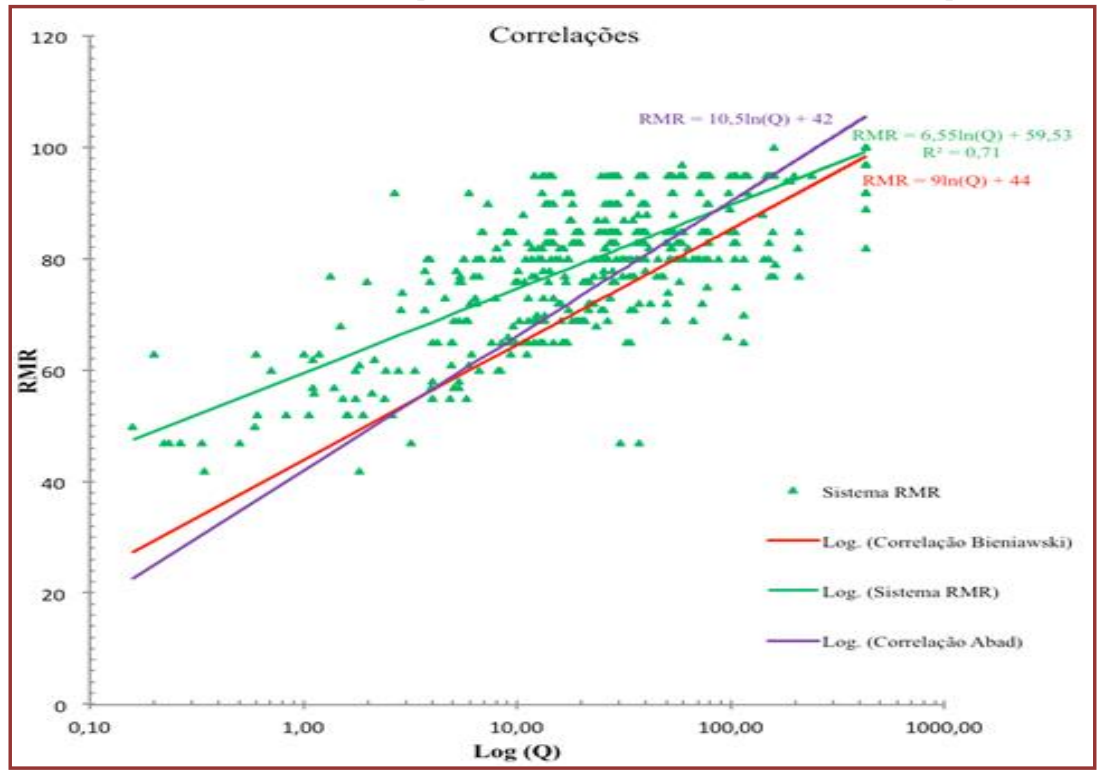

por Bieniawski (1976) e por Abad et al. (1983).

Tabela 2. Comparação e significado das correlações propostas em relação aos resultados obtidos na prática para RMR.

\begin{tabular}{|c|c|c|c|c|c|c|c|}
\hline \multirow{2}{*}{ Furo } & \multirow{2}{*}{ Intervalo (m) } & \multicolumn{2}{|c|}{ Resultados } & \multicolumn{2}{|c|}{ Correlações para RMR } & \multicolumn{2}{|c|}{ (\%) RMR/Correlações } \\
\hline & & $\mathbf{Q}$ & RMR & Bieniawski & Abad et al. & Bieniawski & Abad et al. \\
\hline 133 & $15,10-41,90$ & 0,159 & 50,0 & 27,431 & 22,670 & $182 \%$ & $221 \%$ \\
\hline 124 & $26,80-47,00$ & 0,236 & 47,0 & 31,005 & 26,839 & $152 \%$ & $175 \%$ \\
\hline 124 & $47,00-75,65$ & 0,606 & 52,0 & 39,492 & 36,741 & $132 \%$ & $142 \%$ \\
\hline 88 & $112,25-116,60$ & 14,400 & 80,0 & 68,005 & 70,006 & $118 \%$ & $114 \%$ \\
\hline 88 & $107,60-110,60$ & 29,490 & 95,0 & 74,456 & 77,533 & $128 \%$ & $123 \%$ \\
\hline 134 & $206,55-209,06$ & 35,200 & 77,0 & 76,049 & 79,391 & $101 \%$ & $97 \%$ \\
\hline 129 & $36,80-41,00$ & 99,200 & 85,0 & 85,374 & 90,270 & $100 \%$ & $94 \%$ \\
\hline 138 & $133,65-147,76$ & 120,000 & 92,0 & 87,087 & 92,269 & $106 \%$ & $100 \%$ \\
\hline 87 & $104,60-107,65$ & 159,200 & 95,0 & 89,631 & 95,237 & $106 \%$ & $100 \%$ \\
\hline 130 & $66,35-68,20$ & 189,013 & 94,0 & 91,176 & 97,039 & $103 \%$ & $97 \%$ \\
\hline 130 & $164,15-167,20$ & 426,667 & 100,0 & 98,504 & 105,588 & $102 \%$ & $95 \%$ \\
\hline
\end{tabular}

Fica evidente que, para valores de Q muito abaixo de 30, a correlação obtida no presente estudo e as correlações propostas por Bieniawski e Abad et al. tornam-se fracas, como no caso do menor valor obtido para Q, na linha 1 da Tabela 2. Em contrapartida, os valores de Q muito maiores do que 30,0, principalmente os mais próximos do valor máximo obtido no trabalho, mostram uma boa aplicabilidade das correlações propostas por aqueles autores nesta faixa, resultando em valores de RMR próximos dos valores obtidos na prática, como se observa para o maior valor de Q na linha 11 da Tabela 2.

\section{CONCLUSÕES}

As principais conclusões deste estudo são:

1] Em função das diferenças inerentes à valoração dos parâmetros que os compõem e na subjetividade desta pontuação, os sistemas RMR e Q não são equivalentes e, portanto, sempre haverá uma dispersão nas correlações entre ambos;

2] A correlação obtida no estudo apresentou um coeficiente de determinação considerado entre moderado a forte. Entretanto, não deve ser utilizada para obtenção de parâmetros de projeto, para o que se necessitaria de investigações detalhadas na área de estudo;

3] As correlações propostas por Bieniawski (1976) e Abad et al. (1983) demonstram boa aplicabilidade ao estudo de classificação de maciços da mina de Volta Grande para valores de Q acima de 
30,0. Entretanto, não é recomendado a substituição de parâmetros obtidos no estudo por correlações apresentadas na literatura devendo-se, portanto, aplicar a correlação obtida no presente estudo.

\section{AGRADECIMENTOS}

Os autores agradecem à Universidade Federal de Viçosa e à AMG mineração pelo apoio à realização do estudo.

\section{REFERÊNCIAS}

[1] Abad, J., Celada, B., Chacón, E., Gutierrez, V., Hidalgo, E. Application of geomechanical classification to predict the convergence of coal mines galleries and to design their supports. In: Proc. 5th int. Congress on Rock Mechanics. ISRM. Melbourne, 1983.

[2] Barton, N., Lien, R., Lunde, J. Engineering classification of rock masses for the design of tunnel support. Rock Mechanics, v. 6, n. 4, p. 189-239, 1974.

[3] Bieniawski, Z. T. Engineering classification of jointed rock masses. Transactions of the South African Institution of Civil Engineers, v. 15, p. 335-344, 1973.

[4] Bieniawski, Z.T. Engineering Rock Mass Classifications. New York: John Wiley \& Sons, 1989. 251p.

[5] Hashemi, M., MOGHADDAS, S., Ajalloeian, R. Application of rock mass characterization for determining the mechanical properties of rock mass: a comparative study. Rock Mechanics and Rock Engineering, v. 43, p. 305-320, 2010.

[6] Hoek, E. Pratical Rock Engineereing. 2007. 47p. Disponível em: <http://www.rocscience.com/hoek/corner/Practical_Rock_Engineering.pdf >. Acesso em: 09 de abr. 2015.

[7] International Society For Rock Mechanics - Isrm. The complete ISRM suggested methods for characterization, testing and monitoring: 1974-2006. In: Ulusay, R. \& Hudson, J.A. (Eds.), suggested methods prepared by the Commission on Testing Methods, ISRM. Ankara: ISRM Turkish National Group, 2007. 628p.

[8] Laderian, A., Abaspoor, M., A. The correlation between RMR and Q systems in parts of Iran. Tunneling and Underground Space Technology, v. 27, p. 149-158, 2012.

[9] Nilsen, B., Shrestha, G. L., Panthi, K. K., Holmoy, K. H., Olsen, V. Rmr vs Q vs RMi. Tunnels \& Tunnelling International, v. 35, n. 5, p. 45, 2003. 


\section{Capítulo 6}

Características geotécnicas das rochas encaixantes da camada de carvão barro branco da Bacia Carbonífera Sul-Catarinense

Clovis Gonzatti

João Alberto Fiorentini

Resumo: Embora as maiores reservas de carvão do Brasil estejam situadas no Estado do Rio Grande do Sul, a bacia Carbonífera Sul-Catarinense, localizada no Estado de Santa Catarina, concentra o maior número de minas de carvão em subsolo do País. 0 conhecimento das características mecânicas das rochas que compõem a camada de carvão e as camadas encaixantes é de fundamental importância para o dimensionamento das estruturas de sustentação das minas (pilares) e suporte do teto das escavações. Este trabalho reporta os estudos realizados pela CIENTEC - Fundação de Ciência e Tecnologia do RS sobre rochas sedimentares presentes nas camadas encaixantes da camada de carvão Barro Branco. Os trabalhos de campo consistiram na execução de sondagens rotativas com diâmetro NX utilizando amostrador duplo-móvel. Em laboratório foram realizadas análises petrográficas microscópicas, ensaios para a determinação dos índices físicos e ensaios mecânicos para a determinação da resistência e deformabilidade dos diferentes litotipos. Os resultados permitiram a caracterização das rochas encaixantes da camada de carvão Barro Branco através da definição de padrões típicos de resistência. Esses padrões são usados para a análise da capacidade de carga das rochas encaixantes no processo de dimensionamento dos pilares de sustentação das escavações subterrâneas, quando utilizado o método de lavra por câmaras e pilares. 


\section{INTRODUÇÃO}

Na década de 1990, a CIENTEC - Fundação de Ciência e Tecnologia do RS desenvolveu estudos pioneiros no País, relacionados à mineração de carvão, com o objetivo de estabelecer uma metodologia para o dimensionamento de pilares para minas subterrâneas de carvão do Sul do Brasil (ZORZI 1990). Uma das atividades dentro desses projetos contemplou estudos detalhados em laboratório para a caracterização geomecânica dos materiais presentes nas camadas encaixantes da camada de carvão Barro Branco, a principal camada de carvão minerada em subsolo na Bacia Carbonífera Sul-Catarinense.

0 objetivo dos ensaios em laboratório foi o de definir o comportamento mecânico das rochas encaixantes do teto e piso imediatos da camada de carvão. Na mineração de carvão em subsolo no Brasil, a geometria das galerias consiste em aberturas com 5,5 a $6 \mathrm{~m}$ de largura e altura correspondente à espessura minerada da camada de carvão, da ordem de 1,8 a 2,3 m. Dentro desse contexto, os primeiros $5 \mathrm{~m}$ acima e abaixo da camada de carvão constituem a parcela do maciço rochoso que sofre a maior redistribuição das tensões em função da escavação. Conhecer as características mecânicas e a distribuição espacial dos diferentes litotipos presentes na encaixante do teto é de fundamental importância para o projeto do sistema de suporte das galerias.

De outra parte, quando tratamos do dimensionamento dos pilares de carvão, não deve ser esquecido o papel desempenhado pelas rochas encaixantes, como fundação responsável pelo suporte das cargas transmitidas pelos pilares. 0 método de dimensionamento de pilares de carvão recomendado pelo DNPM Departamento Nacional da Produção Mineral, contempla, na sua concepção, a análise da capacidade de carga das rochas encaixantes (ZORZI et al. 1991). Portanto, conhecer esse atributo das rochas encaixantes é condição básica para o projeto dos pilares das minas de carvão brasileiras.

Neste trabalho, são apresentados os procedimentos adotados para a caracterização geomecânica das rochas encaixantes da camada de carvão Barro Branco, minerada na bacia Carbonífera Sul-Catarinense, no Sul do Brasil. Os procedimentos adotados in situ para a coleta de amostras, as técnicas de preparação das amostras e os procedimentos utilizados para a execução dos ensaios de caracterização física e mecânica, em laboratório, são detalhadas. Os resultados obtidos foram tratados estatisticamente e permitiram a tipificação das principais litologias presentes na Bacia Carbonífera. Essas informações servem de base para o cálculo da capacidade de carga das rochas encaixantes da camada de carvão Barro Branco.

\section{GEOLOGIA DA ÁREA DE ESTUDO}

Geograficamente, todos os locais investigados estão localizados dentro da Bacia Carbonífera SulCatarinense, a qual é parte da porção Leste da bacia do Paraná, conforme Figura 1a, e se estende por vários Estados do Brasil. Os depósitos sedimentares mais antigos pertencem ao período Devoniano. A evolução da bacia possui características intracratônicas.

Dentro da sequência estratigráfica, as litologias carbonosas estão associadas ao Grupo Itararé (basal) e Guatá, com idades do Carbonífero Superior e Permiano Superior. Porém, no Grupo Guatá estão localizadas as camadas de carvão mais espessas, de melhor qualidade e em explotação. Dentre as sete principais camadas, três possuem maior expressão econômica: Barro Branco, conforme indicado na Figura 1b, Irapuá e Bonito.

O condicionamento estrutural encontrado na bacia do Paraná é representado por falhas normais, com planos subverticais. Falhas de empurrão são raras e com pequenos rejeitos. A presença de slikensides causados pela compactação diferencial é frequente. Sistemas de fraturas podem acompanhar as falhas, formando sistemas conjugados, preenchidos ou não por diques de diabásio. 
Figura 1. a) Mapa geológico do Sul do Brasil. Números de I a XIII indicam bacias carboníferas conhecidas no Brasil. IX = Bacia Carbonífera Sul-Catarinense; b) Perfil estratigráfico típico da Formação Rio Bonito,

a)

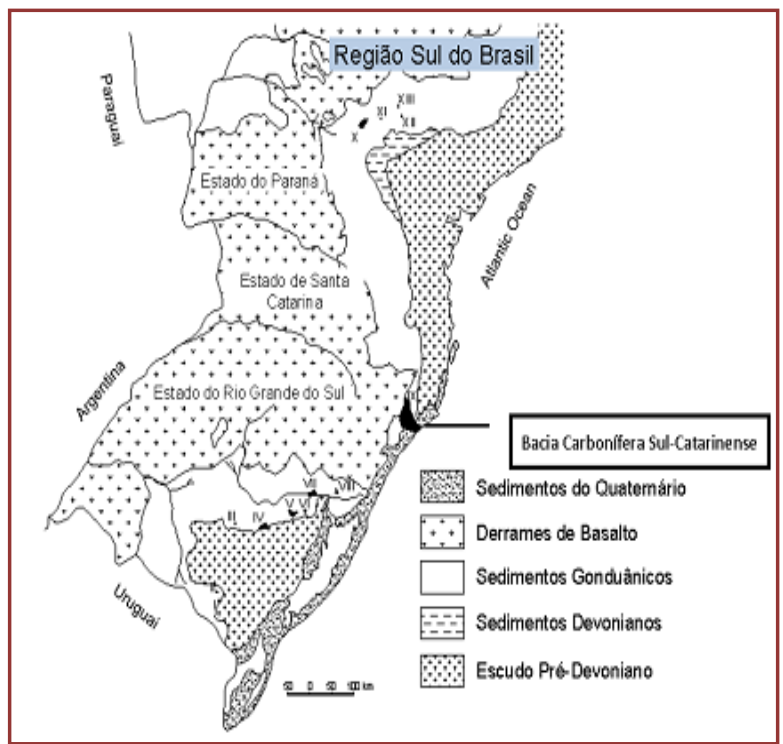

b)

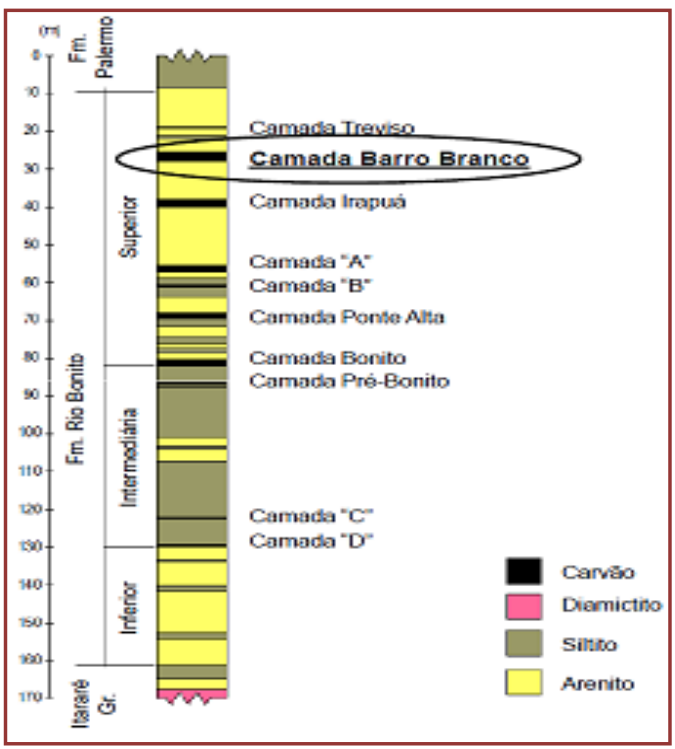

0 piso imediato da camada de carvão Barro Branco é formado, na maior parte, por arenitos de granulação fina à grossa e composição quartzosa. Estes arenitos apresentam, em alguns casos, uma laminação ondulada à lenticular, dada pela presença de material síltico argiloso intercalado. Por vezes podem aparecer camadas de material síltico, às vezes físsil, intercalado ao pacote de arenito. Nas proximidades do piso da camada Barro Branco, localmente, pode ocorrer camada de siltito preto, compacto, fortemente alterável na presença de água.

Já no teto da camada Barro Branco podem aparecer somente arenitos, somente siltitos ou uma sucessão de camadas de arenitos e siltitos. 0 siltito, que compõe o teto imediato em alguns dos locais amostrados, apresenta variações desde siltito cinza escuro ou preto, maciço e consistente, até uma rocha físsil e mais micácea (folhelho síltico), ou então laminado, com lâminas formadas por arenito fino. As demais camadas de siltito que compõem a porção mais superior do teto imediato são normalmente arenosas, com presença de micas e com lentes de arenito fino. A presença de pirita é constante, com proporções variáveis e ocorrendo sob a forma de plaquetas paralelas à fissibilidade e laminação, ou preenchendo fissuras, com ou sem carbonato associado. Os arenitos, por sua vez, são rochas de granulometria fina, às vezes grosseira, quartzosos, pouco micáceos e coerentes. Apresentam contatos nítidos ou gradacionais com os siltitos de base e topo. Nas camadas mais distantes do teto imediato ele se mostra mais micáceo e com lâminas síltico-argilosas.

\section{AMOSTRAGEM}

A seleção dos locais amostrados dentro da Bacia Carbonífera Sul-Catarinense levou em consideração estudos preliminares da geologia e a distribuição dos diferentes litotipos presentes na área em estudo. As sondagens foram realizadas em subsolo a partir de galerias nas frentes de lavra. No total foram realizados 20 furos verticais, amostrando-se em cada local $5 \mathrm{~m}$ no piso e $5 \mathrm{~m}$ no teto, conforme Figura 2, totalizando $100 \mathrm{~m}$ de testemunhos coletados. As amostras foram recuperadas utilizando barrilete duplo móvel, diâmetro NX. Previamente à seleção das amostras para ensaio em laboratório, as diferentes litologias foram descritas macroscopicamente e determinado o RQD - Rock Quality Designation. A Figura 3 apresenta uma síntese das características petrográficas macroscópicas das diferentes classes geomecânicas identificadas nas amostras estudadas. 
Tópicos em Geologia - Volume 1

Figura 2. Testemunhos de sondagem diâmetro NX (54 mm) obtidos nas sondagens das rochas encaixantes do teto e do piso da camada de carvão Barro Branco - Furo 1 - Local de amostragem 1.

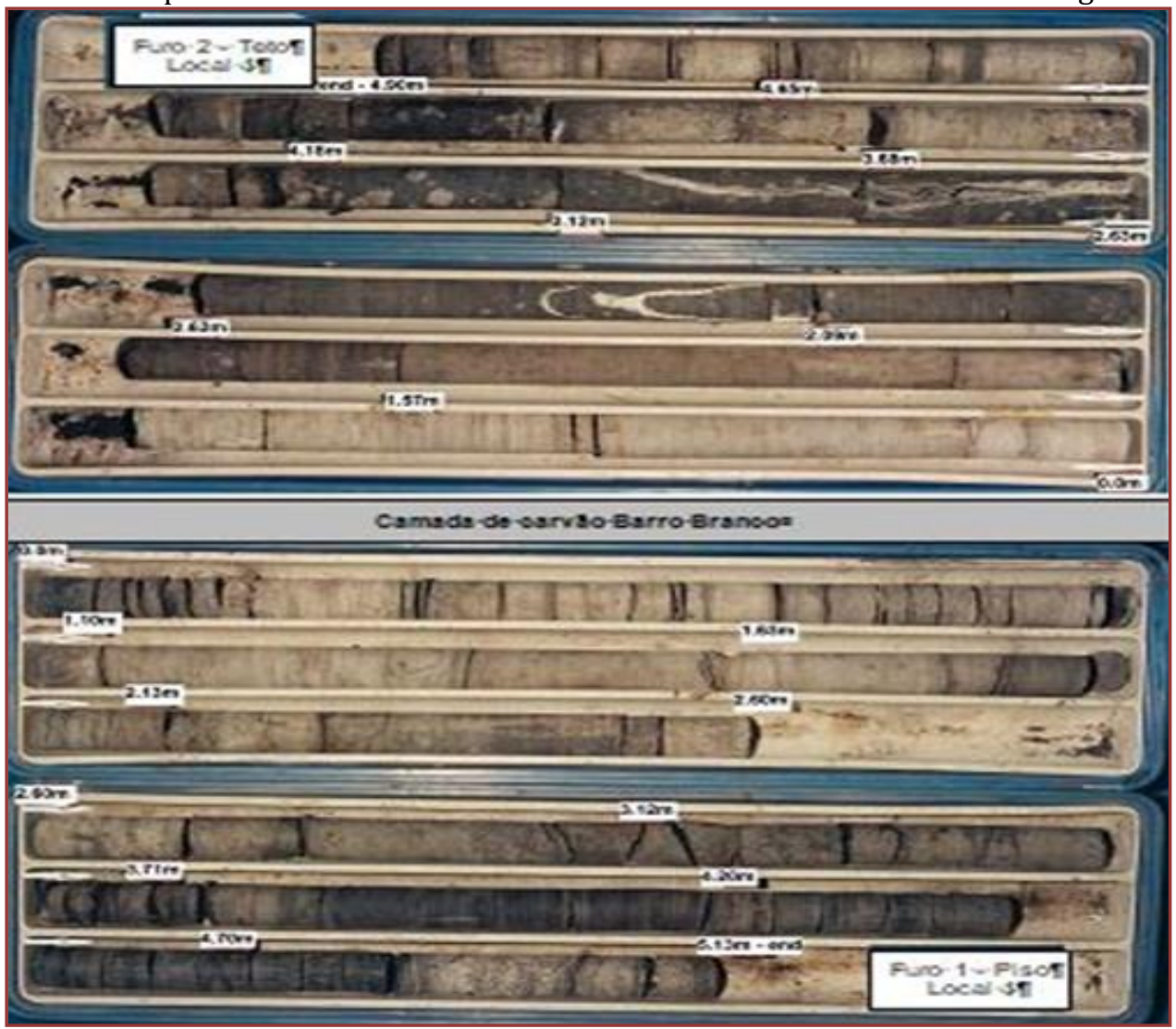

Figura 3. Características petrográficas macroscópicas típicas das diferentes classes geomecânicas.

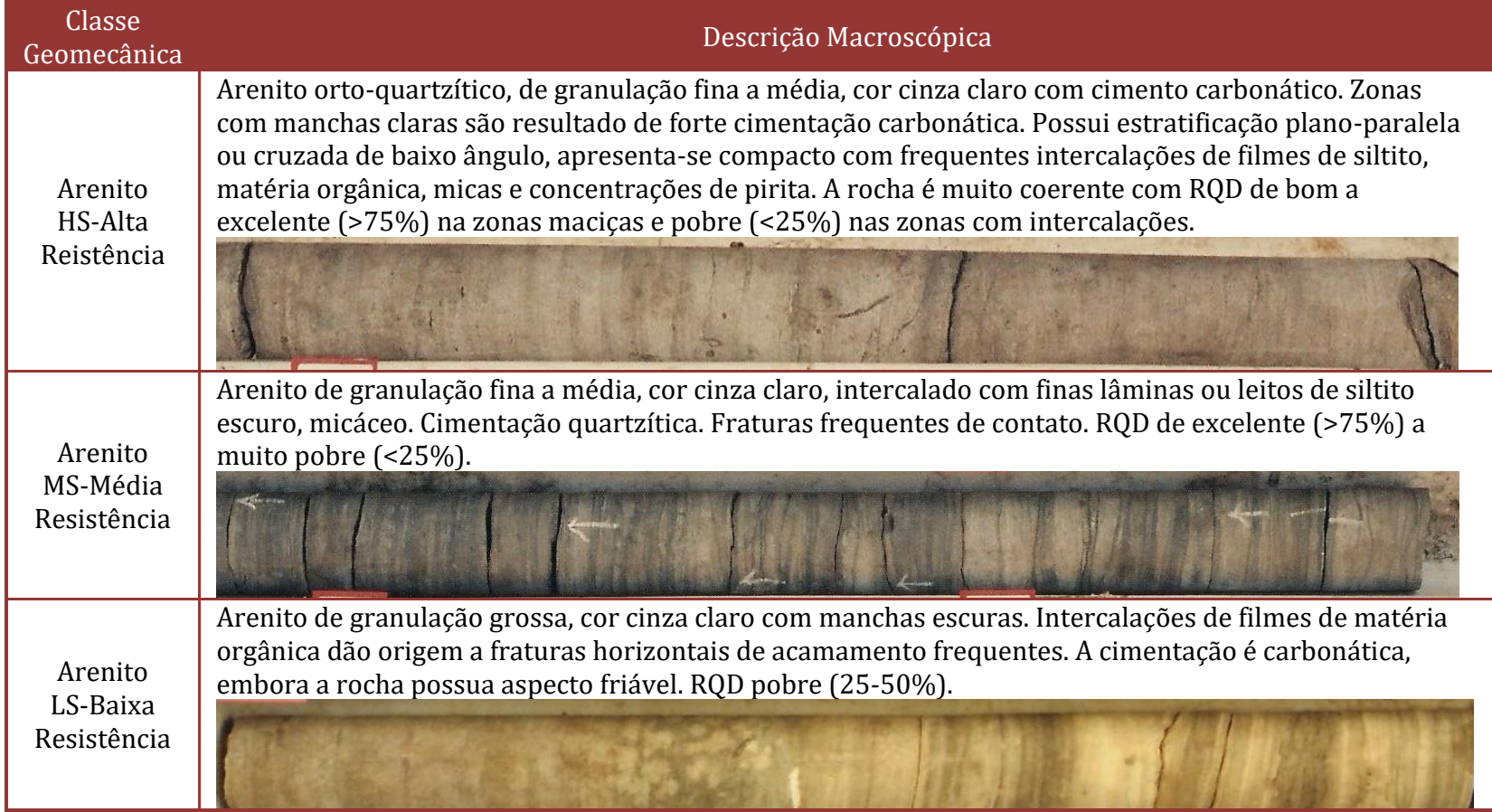


(Continuação ...)

Figura 3. Características petrográficas macroscópicas típicas das diferentes classes geomecânicas.

\begin{tabular}{|c|l|}
$\begin{array}{c}\text { Classe } \\
\text { Geomecânica }\end{array}$ & \multicolumn{1}{c|}{ Descrição Macroscópica } \\
$\begin{array}{c}\text { Siltito } \\
\text { HS-Alta } \\
\text { Resistência }\end{array}$ & $\begin{array}{l}\text { Siltito cinza escuro, com finas lâminas de arenito intercalado. Fraturas muito frequentes nos planos de } \\
\text { acamamento. RQD pobre }(<50 \%) .\end{array}$ \\
\hline $\begin{array}{c}\text { Siltito } \\
\text { LS-Baixa } \\
\text { resistência }\end{array}$ & $\begin{array}{l}\text { Siltito carbonoso intercalado com arenito fino formando pequenas lentes. Apresenta estratificação } \\
\text { plano-paralela, extremamente fraturado nos planos de acamamento. RQD muito pobre }(<25 \%) .\end{array}$ \\
\hline
\end{tabular}

\section{ENSAIOS REALIZADOS}

A preparação dos corpos de prova obedeceu aos procedimentos específicos sugeridos pela ISRM para cada modalidade de ensaio. Previamente aos ensaios mecânicos, foram determinados a massa específica aparente e velocidade sônica (onda P), esta última determinada utilizando um equipamento "PUNDIT" (Portable Ultrasonic Non-Destructive Digital Indicating Tester) com transdutores de $54 \mathrm{KHz}, 1 \mathrm{MHz}$ and 2 MHz. Com o intuito de determinar a envoltória de ruptura das diferentes litologias, ensaios de compressão diametral, compressão uniaxial e compressão triaxial convencional e multiestágio foram realizados. No total, 702 corpos de prova foram ensaiados, conforme quantitativos vistos na Tabela 1. Os quantitativos de massa específica e de velocidade sônica podem ser considerados também a expressão aproximada da proporção de cada classe geomecânica na jazida.

Tabela 1. Quantitativos de ensaios realizados com materiais das diferentes classes geomecânicas.

\begin{tabular}{|c|c|c|c|c|c|c|}
\hline \multirow{2}{*}{$\begin{array}{c}\text { Classe } \\
\text { Geomecânica }\end{array}$} & \multirow{2}{*}{$\begin{array}{c}\text { Massa } \\
\text { Específica } \\
\text { Aparente }\end{array}$} & \multirow{2}{*}{$\begin{array}{c}\text { Velocidade } \\
\text { Sônica }\end{array}$} & \multicolumn{3}{|c|}{$\begin{array}{c}\text { Modalidade de Ensaios } \\
\text { Compressão }\end{array}$} & \multirow{2}{*}{$\begin{array}{c}\text { Módulo de } \\
\text { Young/Coeficiente } \\
\text { de Poisson }\end{array}$} \\
\hline & & & Diametral & Uniaxial & Triaxial & \\
\hline Arenito HS & 344 & 344 & 169 & 85 & 90 & 31 \\
\hline Arenito MS & 91 & 91 & 48 & 22 & 21 & 5 \\
\hline Arenito LS & 73 & 73 & 38 & 17 & 18 & 4 \\
\hline Siltito HS & 134 & 134 & 75 & 30 & 29 & 7 \\
\hline Siltito LS & 60 & 60 & 35 & 14 & 11 & 2 \\
\hline Total de Ensaios & 702 & 702 & 365 & 168 & 169 & 48 \\
\hline
\end{tabular}

Os ensaios de compressão diametral foram realizados em uma prensa Losenhausen com capacidade de carga de $100 \mathrm{kN}$. A tensão de tração indireta foi determinada na direção paralela aos planos de estratificação da rocha.

Para os ensaios de compressão uniaxial e triaxial utilizou-se um sistema de carga com capacidade de $2 \mathrm{MN}$. Nos ensaios triaxiais a tensão confinante foi aplicada com o auxílio de uma câmara triaxial de Hoek. A ruptura seguiu os procedimentos de ensaio individual e/ou multiestágio. Todas as litologias foram ensaiadas na faixa de tensões confinantes entre 10 e $30 \mathrm{MPa}$. Em ambas modalidades de ensaios, a aplicação das cargas foi feita na direção perpendicular aos planos de estratificação da rocha.

Nos ensaios de compressão uniaxial com determinação das constantes elásticas, as deformações foram medidas com extensômetros elétricos tipo strain gages e um sistema eletrônico Kyowa. 0 cálculo do módulo de Young foi feito pelo método do módulo médio, enquanto o coeficiente de Poisson baseou-se no método secante $50 \%$.

Todos os ensaios mecânicos foram realizados baseados nos métodos sugeridos pela ISRM com as amostras na condição de umidade natural entre $0,5 \%$ e $3 \%$.

O processo de classificação geomecânica dos diferentes tipos litológicos estudados foi feito com base na análise petrográfica macroscópica, seguida da análise estatística dos resultados da velocidade sônica, resistência à tração e resistência à compressão uniaxial. Finalmente, utilizaram-se os resultados de todas 
as modalidades de ensaios mecânicos (compressão diametral, uniaxial e triaxial), individualizados por classe geomecânica, para o estabelecimento da envoltória de ruptura média.

Os resultados das diferentes propriedades físicas e mecânicas, após o tratamento estatístico dos dados, permitiu a definição de cinco classes geomecânicas (três classes de arenitos e duas de siltito). Os resultados são apresentados utilizando diagramas de caixas (Box-Whiskers), conforme representação na Figura 4, e podem ser vistos nas Figuras 5 e 6.

A envoltória de ruptura foi determinada com base no critério de Hoek-Brown, versão 2002 (HOEK et al. 2002). 0 cálculo dos parâmetros representativos da envoltória da rocha intacta foi feito utilizando o software RocLab, versão 1.032. No processo de definição da envoltória média de cada classe geomecânica, levou-se em consideração o valor médio da resistência à tração de cada amostra, assim como todos os resultados dos ensaios de compressão uniaxial e triaxial. No total foram estudadas 27 amostras. A Figura 7 mostra resultados típicos de três amostras, enquanto a Figura 8 apresenta a envoltória média de cada uma das 5 classes geomecânicas. Na Tabela 2 são apresentados os parâmetros médios das diferentes propriedades físicas e mecânicas estudadas, incluindo os parâmetros médios das envoltórias de ruptura, para cada uma das 5 classes geomecânicas.

Tabela 2. Parâmetros médios das 5 classes geomecânicas das rochas encaixantes da camada de carvão Barro Branco.

\begin{tabular}{|c|c|c|c|c|c|c|c|c|c|c|}
\hline \multirow{3}{*}{$\begin{array}{c}\text { Classe } \\
\text { Geomecânica }\end{array}$} & \multirow{3}{*}{$\rho\left(\mathrm{g} / \mathrm{cm}^{3}\right)$} & \multirow{3}{*}{$\mathrm{Vp}(\mathrm{km} / \mathrm{s})$} & \multirow{3}{*}{ ITS(MPa) } & \multirow{3}{*}{ UCS(MPa) } & \multirow{3}{*}{$\mathrm{E}_{\mathrm{m}}(\mathrm{GPa})$} & \multirow{3}{*}{$v_{\sec } 50 \%$} & \multicolumn{4}{|c|}{$\begin{array}{l}\text { Parâmetros da Envoltória de } \\
\text { Ruptura da Rocha Intacta }\end{array}$} \\
\hline & & & & & & & \multicolumn{2}{|c|}{$\begin{array}{l}\text { Hoek-Brown } \\
(s=1 ; a=0,5)\end{array}$} & \multicolumn{2}{|c|}{ Mohr-Coulomb } \\
\hline & & & & & & & $\sigma_{\mathrm{ci}}(\mathrm{MPa})$ & $\mathrm{m}_{\mathrm{i}}$ & $c^{\prime}(\mathrm{MPa})$ & $\phi^{\prime}(0)$ \\
\hline Arenito HS & $\begin{array}{c}2,43 \\
(0.07)^{\#}\end{array}$ & $4,2(0,45)$ & $8,2(2,67)$ & $\begin{array}{c}93,0 \\
(26,47)\end{array}$ & $34,0(9,61)$ & $\begin{array}{c}0,31 \\
(0,12)\end{array}$ & 102,6 & $\begin{array}{c}10 \\
2\end{array}$ & 20,6 & 43,2 \\
\hline Arenito MS & $\begin{array}{c}2,51 \\
(0,09)\end{array}$ & $3,9(0,65)$ & $7,6(2,97)$ & $\begin{array}{c}71,0 \\
(14,56)\end{array}$ & $22,1(2,84)$ & $\begin{array}{c}0,37 \\
(0,12)\end{array}$ & 75,9 & 7,0 & 16,8 & 38,9 \\
\hline Arenito LS & $\begin{array}{c}2,44 \\
(0,08)\end{array}$ & $3,1(0,51)$ & $5,1(1,74)$ & $\begin{array}{c}42,3 \\
(13,71)\end{array}$ & $10,8(1,90)$ & $\begin{array}{c}0,34 \\
(0,11)\end{array}$ & 56,1 & 7,9 & 12,0 & 40,3 \\
\hline Siltito HS & $\begin{array}{c}2,58 \\
(0,08)\end{array}$ & $3,8(0,56)$ & $6,8(1,79)$ & $\begin{array}{c}57,3 \\
(16,64)\end{array}$ & $18,7(3,37)$ & $\begin{array}{c}0,24 \\
(0,05)\end{array}$ & 57,9 & 6,2 & 13,5 & 37,5 \\
\hline Siltito LS & $\begin{array}{c}2,50 \\
(0,06)\end{array}$ & $2,6(0,95)$ & $4,3(1,46)$ & $\begin{array}{c}38,3 \\
(7,90)\end{array}$ & $\begin{array}{c}2,9 \\
(0,57)\end{array}$ & $\begin{array}{c}0,33 \\
(0,10)\end{array}$ & 32,7 & 4,1 & 8,4 & 32,5 \\
\hline
\end{tabular}

\# Valores entre parênteses = desvio padrão.

Figura 4. Significado da representação de dados estatísticos em digramas de caixas (Box-Whiskers).

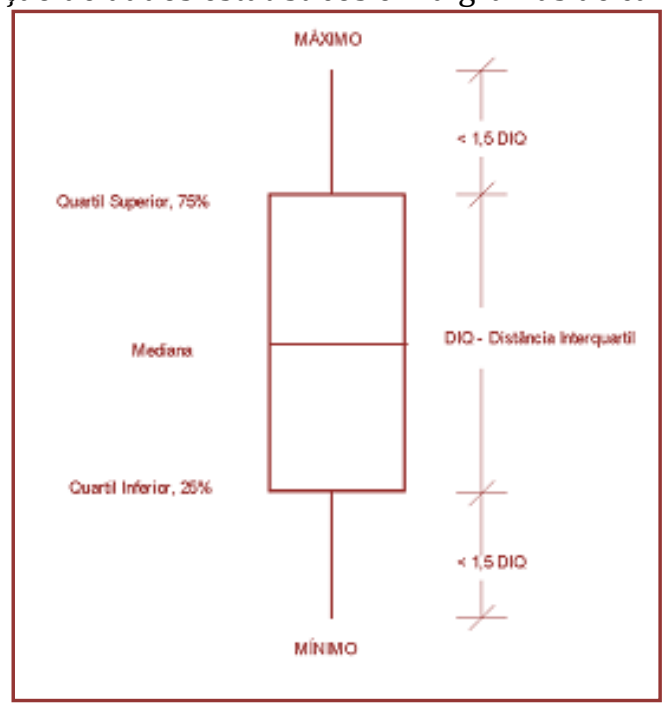


Figura 5. Propriedades físicas das diferentes classes geomecânicas das rochas encaixantes da camada de carvão Barro Branco.

a)

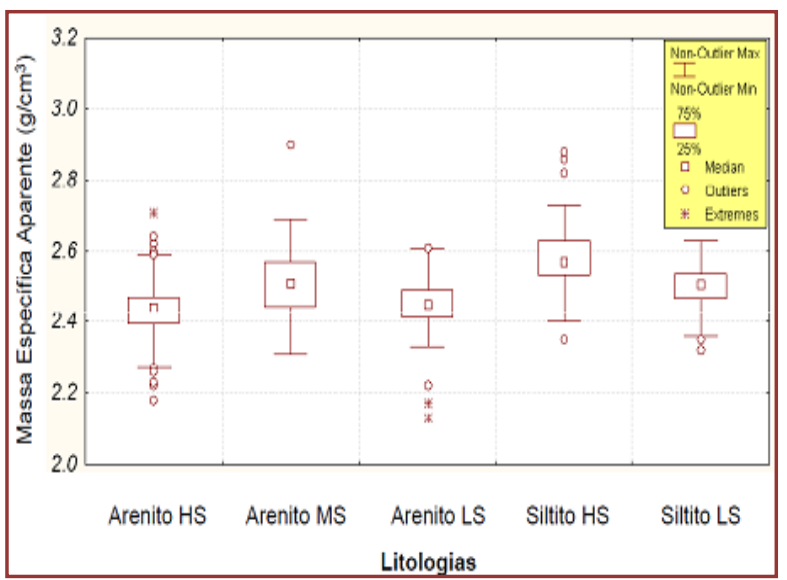

b)

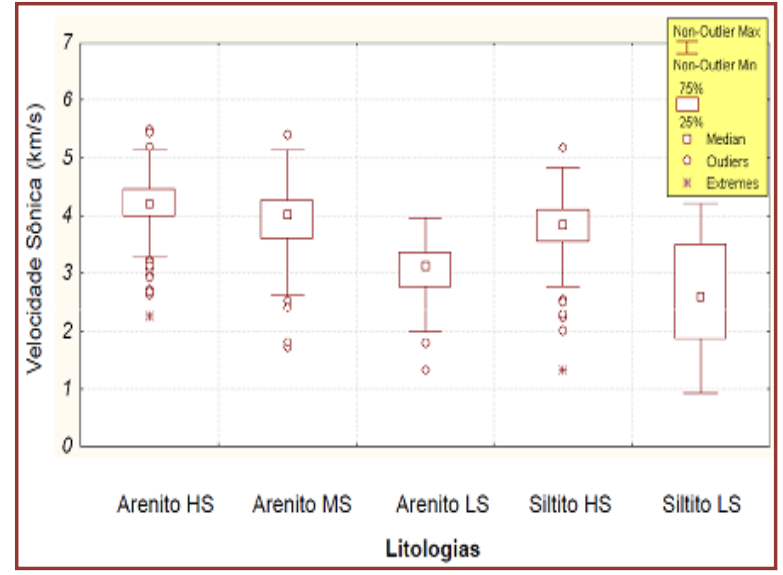

Figura 6. Propriedades mecânicas das diferentes classes geomecânicas das rochas encaixantes da camada de carvão Barro Branco.

a)

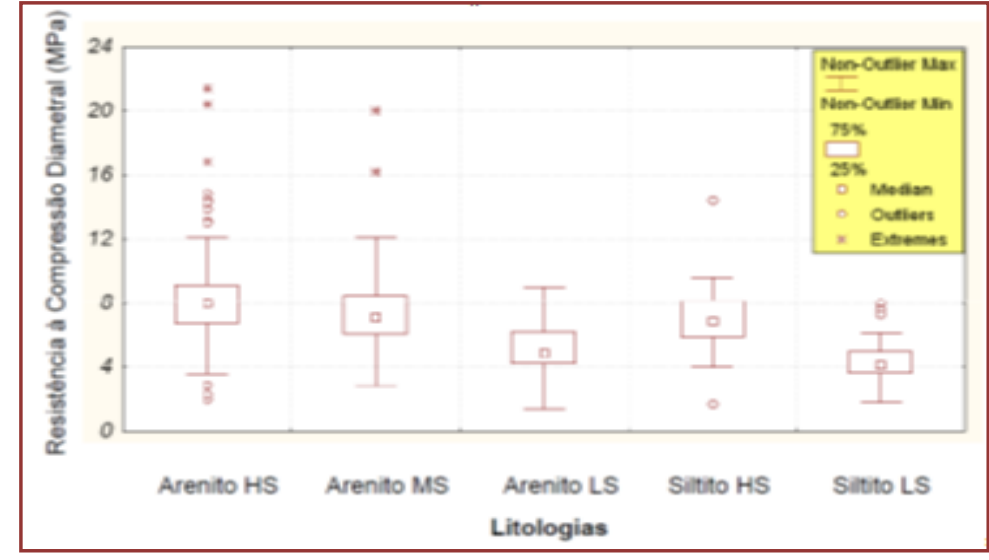

b)

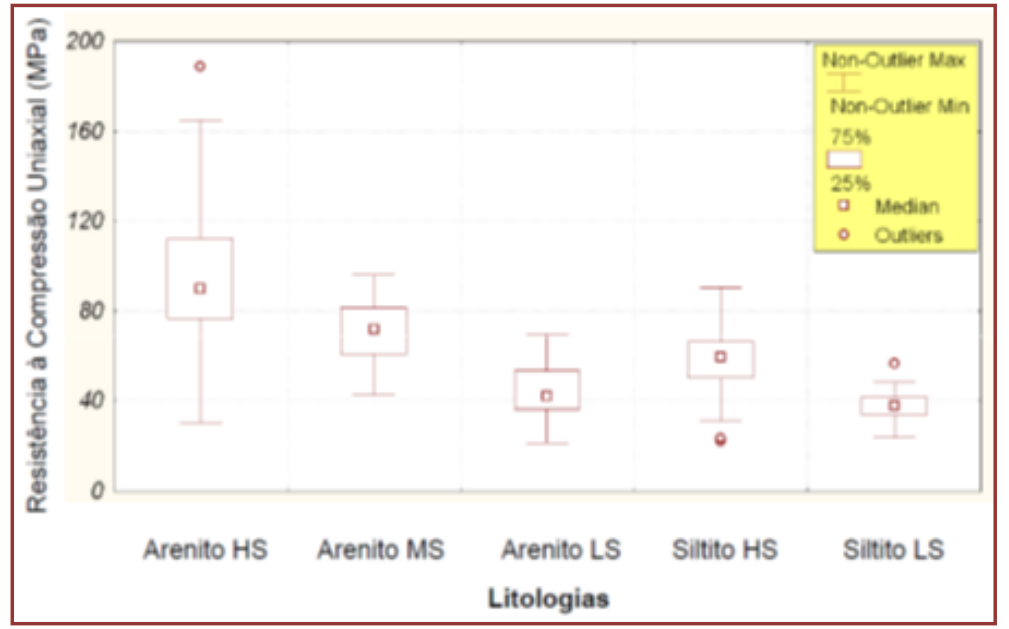


c)

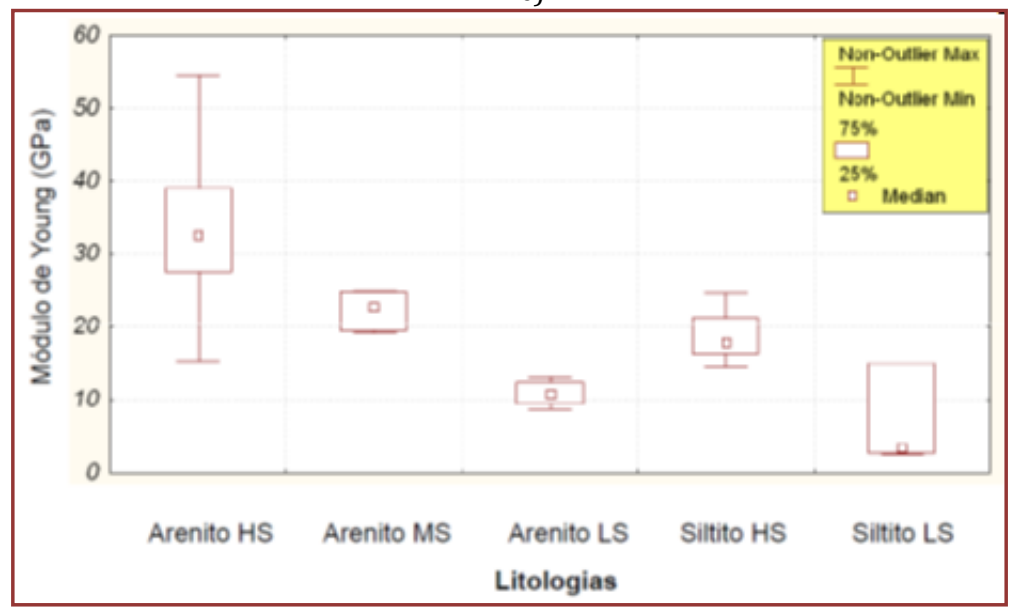

Figura 7. Envoltórias típicas de ruptura, de acordo com o critério de Hoek-Brown, de amostras das camadas encaixantes da camada de carvão Barro Branco.

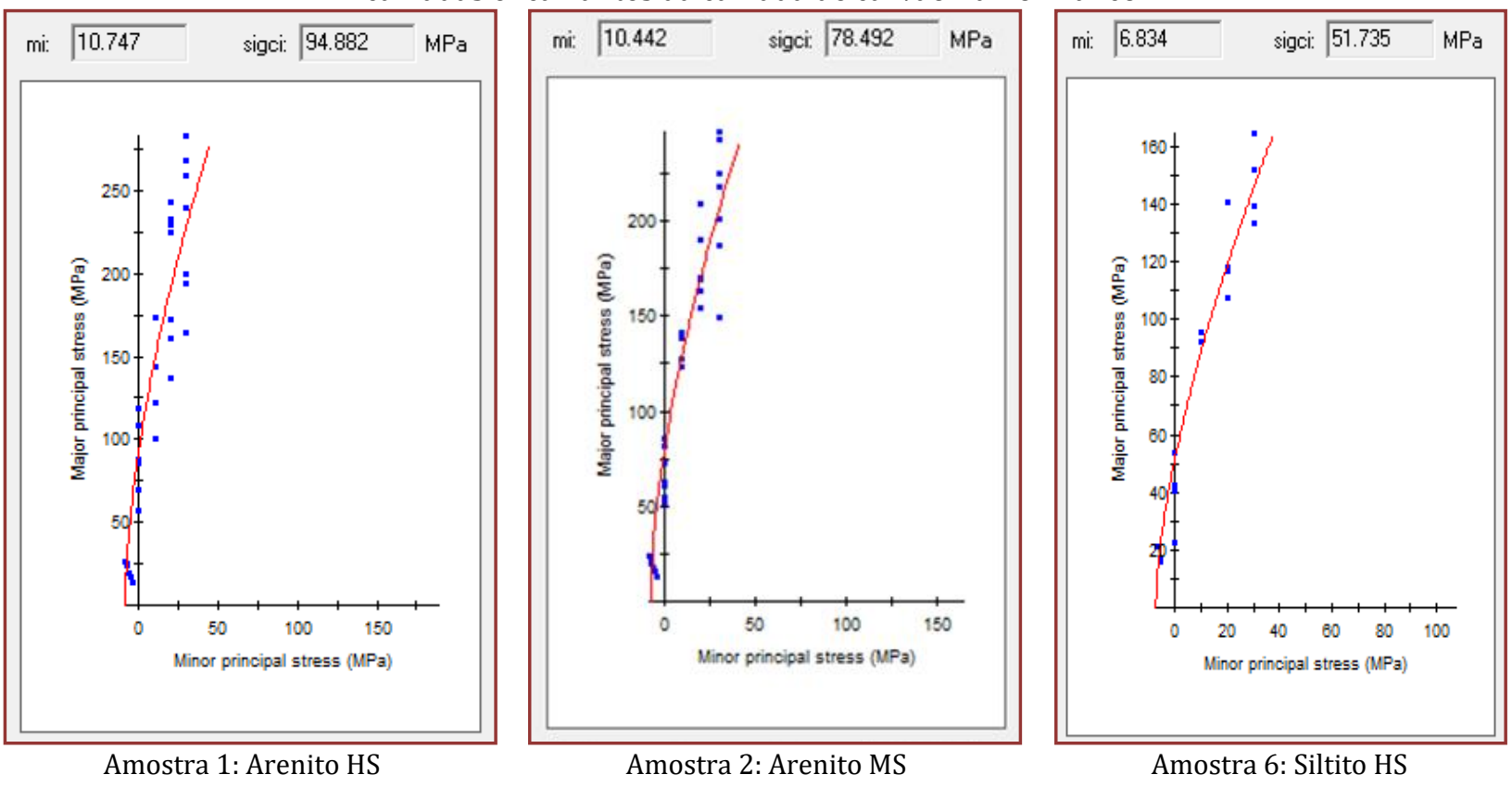


Figura 8. Envoltórias de ruptura média de acordo com o critério de ruptura de Hoek-Brown representativas das 5 diferentes classes geomecânicas das rochas encaixantes da camada de carvão Barro Branco

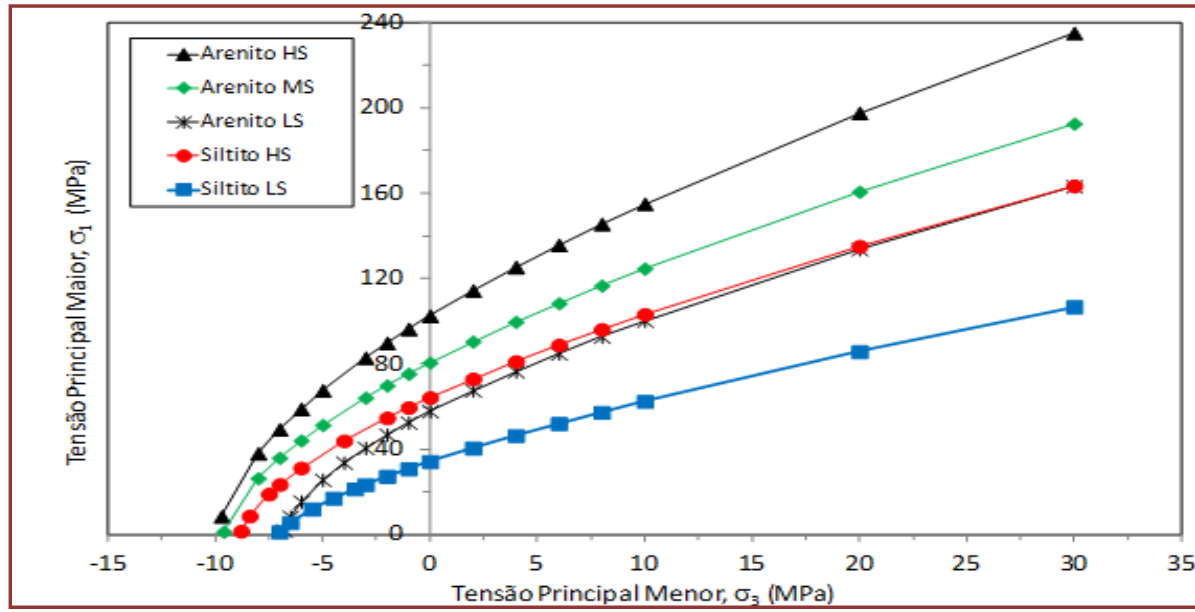

$\rho=$ massa específica aparente natural; $\mathrm{Vp}=$ velocidade sônica; ITS=resistência à tração indireta; UCS=resistência à compressão uniaxial; $E_{\mathrm{m}}=$ módulo de Young médio; $v_{\mathrm{sec}} 50 \%=$ coeficiente de Poisson secante $50 \%$; $\sigma_{\mathrm{ci}}=$ resistência à compressão uniaxial; $\mathrm{m}_{\mathrm{i}, \mathrm{s}} \mathrm{a}$ =constantes do critério de Hoek-Brown; $\mathrm{c}^{\prime}=$ coesão; $\phi^{\prime}=$ angulo de atrito.

\section{ANÁLISE DOS RESULTADOS}

Os materiais rochosos presentes nas encaixantes da camada de carvão Barro Branco, na Bacia Carbonífera Sul-Catarinense, mostram claramente duas litologias distintas: arenitos e siltitos. Tendo como base as características petrográficas macroscópicas, físicas e as propriedades mecânicas das rochas estudadas, foram definidas 5 classes geomecânicas, conforme visto na Tabela 2 .

Geomecanicamente, os arenitos podem ser divididos em três classes: Arenito HS, de grão fino, o mais resistente; Arenito LS, de grão médio a grosso, o menos resistente; Arenito MS, de grão médio a fino, praticamente impossível de ser separado apenas pela descrição macroscópica. Os siltitos, por seu lado, são divididos em duas classes: Siltito HS e o Siltito LS. Macroscopicamente esses siltitos se distinguem apenas pelo grau de fissilidade, uma vez que pela textura e cor são muito semelhantes.

Os materiais pertencentes às classes geomecânicas Arenito HS e Siltito HS representam aproximadamente $50 \%$ e $20 \%$, respectivamente, das litologias amostradas. Cada uma das três outras classes representa cerca de $10 \%$.

As propriedades físicas permitem a distinção das 5 classes apenas pela velocidade sônica, conforme Figura 5b. É notável a diferença da velocidade (mediana) entre as três classes de arenitos, assim como entre as duas classes de siltitos. Da mesma forma, mecanicamente, tanto a resistência à tração como a de compressão evidenciam claramente a presença de 5 classes de resistência, embora as classes geomecânicas Arenito LS e Siltito LS sejam semelhantes, como visto nas Figuras 6a e 6b.

Do ponto de vista da resistência ao cisalhamento, a envoltória de ruptura das diferentes classes geomecânicas sugere a existência de apenas 4 classes geomecânicas com características distintas, sendo duas de arenitos e duas de siltitos. Embora na região de tração as classes geomecânicas Arenito LS e Siltito LS sejam semelhantes mecanicamente, na condição confinada é a classe geomecânica Arenito LS que se assemelha ao Siltito HS, conforme Figura 7 e os resultados na Tabela 2. A explicação para esse comportamento pode estar associada à textura do Arenito LS (grãos maiores e mais rugosos), quando comparado com as classes de siltitos. Esses aspectos texturais do Arenito LS, associados ao confinamento, produzem um aumento na dilatância durante a ruptura, com o consequente aumento da resistência ao cisalhamento. 


\section{CONCLUSÕES}

Os estudos realizados permitiram a caracterização geomecânica das principais litologias presentes nas encaixantes da camada de carvão Barro Branco, da Bacia Carbonífera Sul-Catarinense. Pelo menos 5 classes geoemecânicas foram definidas em função das diferentes propriedades físicas e mecânicas determinadas em laboratório.

As classes geomecânicas Arenito HS, Arenito MS e Siltito HS representam aproximadamente $80 \%$ das rochas presentes nas encaixantes do teto e piso da camada de carvão Barro Branco. Essas classes também se constituem nas rochas de melhor qualidade mecânica. De outra parte, as classes Arenito LS e Siltito LS representam cerca de $20 \%$ das rochas encaixantes. De acordo com procedimentos sugeridos por ZORZI et al. (1991) para o dimensionamento dos pilares, quando em contato com a camada de carvão, as rochas encaixantes devem ser analisadas quanto à capacidade de carga.

\section{REFERÊNCIAS}

[1] Isrm - International Society for Rock Mechanics (1978). Suggested methods for determining sound velocity. Int. Journal of Rock Mech. and Min. Scienc. \& Geomech. Abstr.. Vol. 15, no 2, p. 53-58.

[2] Isrm - International Society for Rock Mechanics (1978). Suggested methods for determining tensile strength of rock material. Int. Journal of Rock Mech. and Min. Scienc. \& Geomech. Abstr.. Vol. 15, no 3, p. 99-103.

[3] Isrm - International Society for Rock Mechanics (1979). Suggested methods for determining water content, porosity, density, absorption and related properties and swelling and slake-durability index properties. Int. Journal of Rock Mech. and Min. Scienc. \& Geomech. Abstr.. Vol. 16, no 2, p. 141-156.

[4] Isrm - International Society for Rock Mechanics (1979). Suggested methods for determining the uniaxial compressive strength and deformability of rock materials. Int. Journal of Rock Mech. and Min. Scienc. \& Geomech. Abstr.. Vol. 16, no 2, p. 135-140.

[5] Isrm - International Society for Rock Mechanics (1983). Suggested methods for determining the strength of rock materials in triaxial compression: revised version . Int. Journal of Rock Mech. and Min. Scienc. \& Geomech. Abstr.. Vol. 20, no 6, p. 283-290.

[6] Zorzi, L. (coord.) (1990). Projeto: Dimensionamento de Pilares em Minas de Carvão. Cientec - Fundação De Ciência E Tecnologia. Porto Alegre, 2v.

[7] Zorzi, L.; Agostini, I. M.; Gonzatti, C. (1991). Metodologia para dimensionamento de pilares em minas de carvão do Sul do Brasil. Cientec - Fundação De Ciência E Tecnologia, Porto Alegre, 23p. (Boletim Técnico no 23).

[8] Hoek, E.; Carranza-Torres, C.; Corkum, B. (2002). Hoek-Brown failure criterion - 2002 edition. In.: North American Rock Mechanics Symposium, 5th. Proceedings. Toronto, Canadá, v. 1, p. 267-273. 


\section{Capítulo 7}

\section{Caracterização fisiográfica de bacia hidrográfica localizada no município de Russas/CE}

\section{Milena de Brito Espinosa \\ Robervan Alves de Araujo \\ Sarah Lacerda Farias \\ Thaynara D'Avalo Centurião \\ Isabel Kaufmann de Almeida}

Resumo: 0 estudo das características físicas de uma bacia hidrográfica é de suma importância para conhecer a variação no espaço dos elementos do regime hidrológico. Além disso, através dessa análise é possível determinar indiretamente valores hidrológicos em locais que faltem dados, entre outras vantagens. 0 objetivo do estudo foi discutir a fisiografia da bacia nomeada de acordo com o município predominante (Russas), localizada na região nordeste brasileiro. Para isso foram analisados parâmetros como: área de drenagem, forma da bacia, sistema de drenagem, relevo e características geológicas, térmicas, tipo e uso do solo e cobertura vegetal. Com os resultados obtidos concluiu-se que a bacia, devido a fatores como baixo fator de forma, alto coeficiente de compacidade, baixa declividade, clima, entre outros, apresenta menor suscetibilidade a enchentes. Os solos da bacia apresentam baixa fertilidade natural e 0 Argissolo Vermelho-Amarelo abrange 61\% da área e o Planossolo Háplico 39\%, ambos com relevo plano e suave ondulado. Esses solos possuem algumas características que, juntamente com ações antrópicas como a agropecuária, maximizam os processos erosivos da região, mesmo com relevo pouco acentuado (baixa declividade - 3,23\%).

Palavras-Chave: Morfometria; Enchentes; Geologia; Hidrologia. 


\section{INTRODUÇÃO}

Para avaliação do comportamento hidrológico é de suma importância medir numericamente as influências das características topográficas, geológicas, geomorfológicas, pedológicas e térmicas, bem como o tipo de cobertura e uso da bacia hidrográfica (GARCEZ \& ALVAREZ, 1988). Existem várias definições de bacia hidrográfica. Segundo Teodoro et al. (2007), as definições que envolvem as subdivisões da bacia hidrográfica (sub-bacia e microbacia), apresentam abordagens diferentes tocando fatores que vão do físico ao ecológico. Assim, as definições propostas para bacia hidrográfica assemelham-se ao conceito dado por Schiavetti (2002), definido como um conjunto de terras drenadas por um rio principal, seus afluentes e subafluentes, onde os escoamentos convergem para um único ponto de saída, o exutório. Estando associada à noção de existência de nascentes, divisores de água e características dos cursos d'água.

A bacia hidrográfica é um elemento fundamental de análise da fase terrestre do ciclo hidrológico, pois possui um importante papel, que é transformar uma entrada de volume concentrada (precipitação), em uma saída de água (escoamento) de forma mais distribuída no tempo (TUCCI, 1997). A sua caracterização fisiográfica é, portanto, a mais conveniente possibilidade de se conhecer a variação no espaço dos elementos do regime hidrológico (VILLELA \& MATOS, 1975).

Através do estudo das características fisiográficas (área de drenagem, declividade média da bacia, comprimento do rio principal, fator de forma, coeficiente de compacidade, dentre outras) pode-se, por exemplo, entender fenômenos passados, avaliar impactos de alterações antrópicas na fase de escoamento superficial da água e transpor dados hidrológicos conhecidos para determinação indireta em seções nos quais faltem dados ou que não possuam estações hidrométricas (PORTO et al., 1999).

No presente trabalho, a área de estudo restringiu-se à bacia hidrográfica localizada em sua maior extensão dentro da delimitação geográfica do município de Russas, na porção leste do Ceará. Essa bacia foi escolhida por apresentar, na maioria de sua superfície, solos moderadamente ou imperfeitamente drenados, e passíveis de erosão. Objetiva-se apresentar a análise fisiográfica da bacia hidrográfica através da sua caracterização, determinação de fatores do sistema de drenagem e elementos relacionados à forma da bacia e cálculo dos coeficientes sobre o relevo.

\section{MATERIAL E MÉTODOS}

As características fisiográficas se dividem basicamente em áreas, comprimentos, declividades e coberturas do solo, medidas diretamente ou expressas por índices (TUCCI, 1997). As metodologias para análise dessas características foram realizadas segundo Garcez e Alvarez (1988) e Villela e Matos (1975).

Para a caracterização da bacia utilizou-se o software livre de geoprocessamento QGIS 2.14.5 e foi utilizado como base o Modelo Digital de Elevação (MDE), através do sensor SRTM (Shuttle Radar Topographic Mission) de 30 metros, obtido no site Earth Explorer, administrado pelo USGS (United States Geological Survey).

Os dados hidrográficos foram extraídos do Portal de Metadados Geoespaciais da Agência Nacional de Águas (ANA) em formato shape (.shp). As curvas de nível foram extraídas do MDE com intervalos entre linhas de contorno em 5 metros para delimitação da bacia que foi feita com a determinação do exutório, de modo que não cruzasse um curso d'água, observando as curvas de nível.

\section{1.ÁREA DE ESTUDO}

A região nordeste (NE) do Brasil contempla cinco das doze regiões hidrográficas brasileiras, sendo elas: Atlântico Nordeste Oriental, Atlântico Nordeste Ocidental, Atlântico Leste, Parnaíba e São Francisco. Assim, foi estudada uma bacia hidrográfica da região nordeste, localizada em Russas, no estado do Ceará Bacia Principal: Atlântico Nordeste Oriental e Sub-Bacia: rio Acaraú e Pirangi (SNIRH, 2017) com 163,95 $\mathrm{km}^{2}$ de área de drenagem, perímetro de $65,05 \mathrm{~km}$ e seção exutória localizada na coordenadas médias: 38.257459 0, -4.790191S.

A bacia foi denominada de Russas, pois apresenta grande extensão dentro da delimitação geográfica do município de Russas, contendo cerca de 70.000 mil habitantes (IBGE, 2017). A economia da cidade está relacionada com o comércio, administração e serviços públicos, indústria (calçadista, cerâmica e peças automotivas) e agronegócio (frutas) (IBGE, 2016). A cidade apresenta vegetação do tipo savana-estépica (caatinga do sertão árido), como cobertura vegetal natural há presença de região arborizada e de parques, destacando a ação antrópica, atividades agrárias (IBGE, 2004). A região destaca-se pelo clima Tropical 
Nordeste Oriental semi-árido com 7 a 8 meses de estiagem (IBGE, 2002). Essa localidade possui em média $65,37 \mathrm{~mm} / \mathrm{mês}$ de intensidade pluviométrica (ANA, 2017). Entretanto, a atividade de agricultura é viável através da irrigação proveniente do rio Jaguaribe (RUSSAS, 2017).

\subsection{CARACTERIZAÇÃO GEOLÓGICA E TIPO DE SOLO}

A caracterização geológica e os tipos de solos da região são de grande importância, pois permitem análise de permeabilidade, que é um fator que intervém na rapidez e no volume das enchentes. Além disso, auxiliam na identificação de lençóis, aquíferos, escoamento subterrâneo, origem das fontes e erosão.

A caracterização geológica da bacia de Russas foi obtida do banco de dados do Sistema de Geociências (GeoSGB) do Serviço Geológico do Brasil - CPRM, em formato shape (.shp). Para a classificação dà gênese foi utilizado o mapa geológico simplificado e para às unidades geológicas utilizou-se o mapa hidrogeológico. Na determinação da classificação do solo disponibilizado pela EMBRAPA, elaborado com base no novo sistema brasileiro de classificação de solos (EMBRAPA, 2001).

A morfologia e a gênese são a base da taxonomia de solos (GREGO et al., 2011). Portanto, através do ciclo das rochas, características são alteradas, podendo existir três tipos de grupo de rochas que são ígneas, metamórficas e sedimentares, de acordo com seu processo de formação, e dependendo em que estágio do ciclo o solo se encontra (MENEZES, 2013).

A gênese apresentada na bacia de Russas (Figura 1a) é caracterizada por terrenos em sua maior parte metamórficos, com pequenas partes ígneas e sedimentares. Seu solo é composto de Argissolo VermelhoAmarelos e Planossolo Háplico (Figura 1b).

Figura 1a) Classificação de formação das rochas 1b) Tipos de solo.

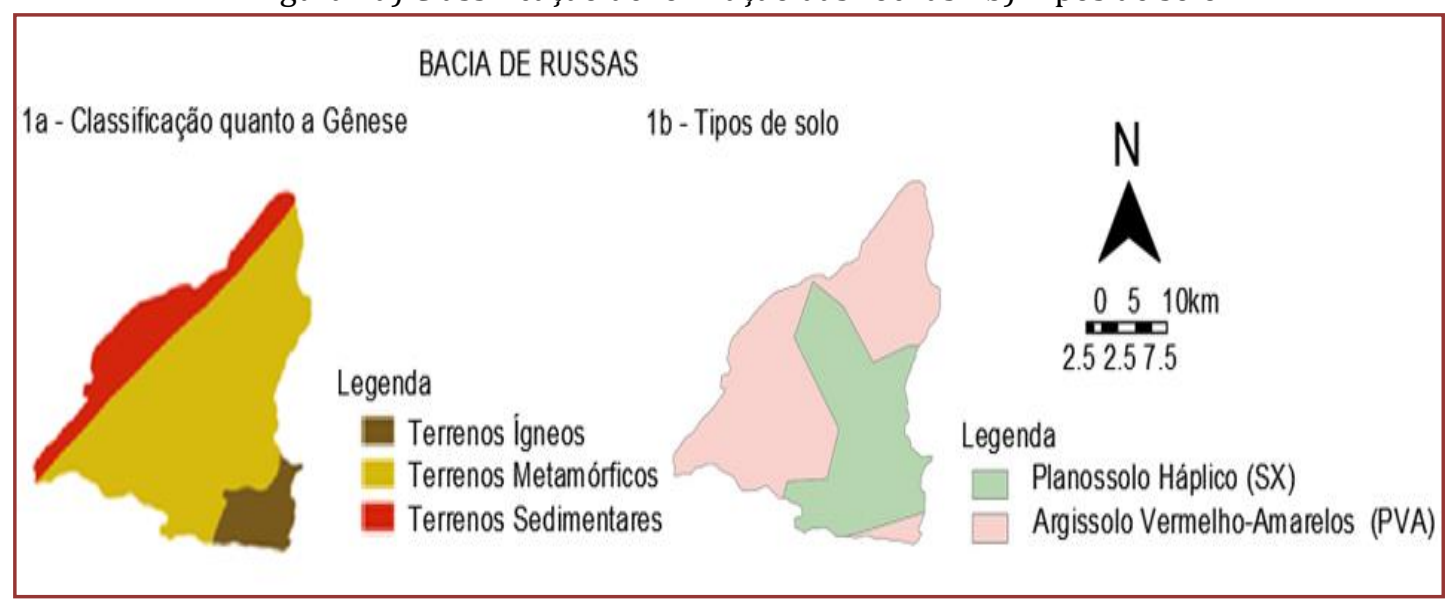

Conforme Lima et al. (2002), o solo argissolo vermelho-amarelo (PVA) apresenta nula suscetibilidade à erosão. Entretanto a região de solo planossolo háplico (SX) apresenta moderada suscetibilidade à erosão. Ademais, pode-se observar que há suscetibilidade para ocorrência de desertificação na região de solo planossolo háplico (SX), pois a região apresenta processo erosivo (SPI, 2016)

\subsection{COBERTURA VEGETAL E USO DO SOLO}

As informações referentes à cobertura vegetal, relacionadas com o uso do solo da bacia de Russas, foram retiradas do mapeamento de cobertura vegetal dos biomas brasileiros, realizado pelo Ministério do Meio Ambiente em parceria com o IBGE, disponibilizado no formato shapefile.

As atribuições do terreno podem controlar processos hidrológicos, geomorfológicos e pedológicos (CHAGAS et al., 2013). A bacia de Russas possui como vegetação a Savana Estépica Arborizada e a presença de agropecuária, também possuindo banhados (Figura 2).

A presença da agropecuária pode potencializar a erosão do solo, com presença de sulcos e voçorocas, sendo necessário o manejo desenvolvido para que haja controle do processo de erosão para a agricultura e rotação de cultura para pecuária (LIMA et al., 2002; SPI, 2016) 
Figura 2 - Mapa de uso do solo e cobertura vegetal presentes na bacia de Russas.

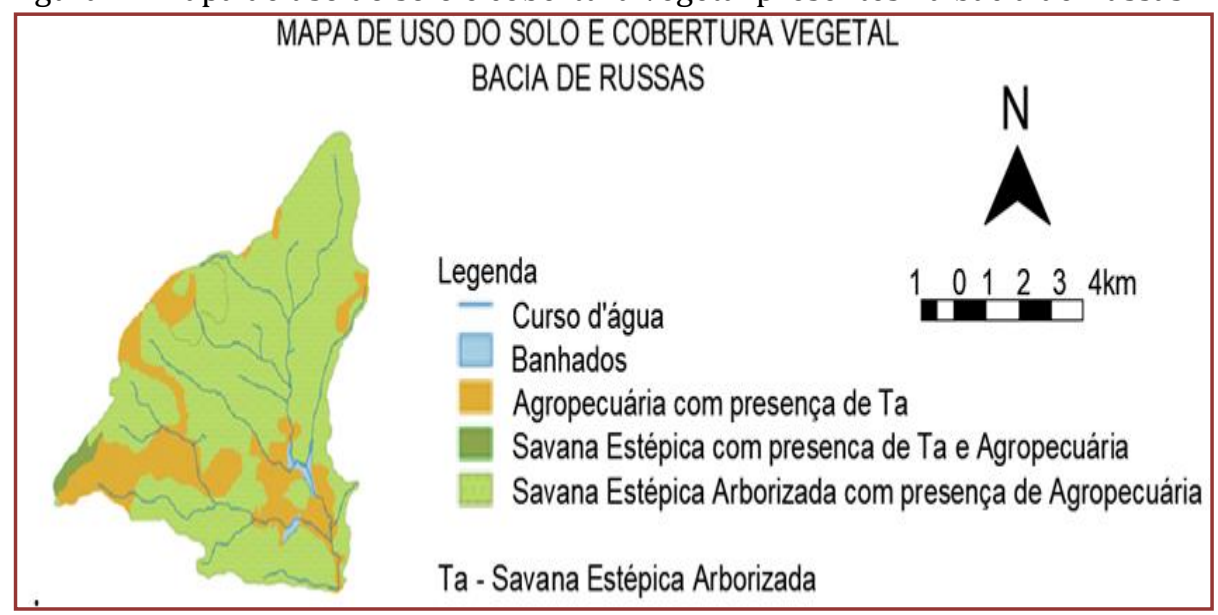

\subsection{CARACTERÍSTICAS CLIMÁTICAS}

Alguns fatores foram destacados: o clima, a pluviosidade, a temperatura do ar (bulbo seco), a evapotranspiração e a umidade relativa do ar. Os dados referentes ao clima foram retirados do mapa do Instituto Brasileiro de Geografia e Estatística (IBGE). As informações pluviométricas foram obtidas utilizando duas plataformas. Na primeira foi realizada a coleta dos dados de identificação das estações pluviométricas, extraída do Sistema Nacional de Informações sobre Recursos Hídricos (SNIRH), obtendo assim a estação pluviométrica de Patos-CE, código SNIRH 438040. A estação foi escolhida dentre a que se encontrava dentro da área da bacia e/ou a com localização mais próxima. Somado ao exposto, a segunda plataforma foi utilizada para a obtenção das séries históricas de pluviometria da estação através da Agência Nacional de Águas (ANA).

As informações relacionadas à temperatura, evapotranspiração e umidade relativa do ar, foram obtidas através do Instituto Nacional de Meteorologia (INMET, 2017) e extraídas da estação pluviométrica Morada Nova-CE, código INMET 82588.

As séries históricas de pluviometria, temperatura, evapotranspiração e umidade relativa foram submetidas à criteriosa conferência para identificar falhas. Ademais, onde apresentavam apenas um ou dois valores seguidos foi utilizado o preenchimento de falhas por regressão linear. Para até quatro falhas no ano de observação foi utilizada a mesma metodologia. Foram descartados os anos de referência com cinco ou mais falhas.

Observa-se um período com maior intensidade pluviométrica, nos meses de março e abril, e de baixa intensidade nos meses de julho à dezembro, o que contribui para a classificação de clima Tropical Nordeste Oriental semi-árido (IBGE, 2002), conforme Figura 3a.

Nota-se período de temperaturas amenas nos meses de junho e julho, quando a temperatura apresenta pouca influência das chuvas, uma vez que a maior pluviosidade se concentra entre os meses de janeiro a maio e as maiores temperaturas de setembro a fevereiro. Conforme Figura $3 \mathrm{~b}$, as temperaturas referentes à bacia de Russas mantêm-se elevadas, praticamente, em todo ano, sendo que as temperaturas mais baixas se concentram no período de início de estiagem, junho a agosto.

A evapotranspiração (Figura 3c) acompanha, em sua maioria, a tendência da temperatura, uma vez que maiores temperaturas auxiliam na evaporação da água contida no solo, vegetação e cursos d'água.

A umidade relativa segue com taxas com pouca variação no decorrer do ano. Observa-se que a evapotranspiração e a umidade são inversamente proporcionais, ou seja, nos meses de maior umidade há menor evapotranspiração (março à maio) e maiores evapotranspiração nos meses mais secos (setembro à dezembro), conforme Figuras 3c e 3d. 
Figura 3a) Distribuição de intensidade pluviométrica (mm/mês), estação Patos (CE), período 1962-

2016.3b) Distribuição de temperatura média, estação Morada Nova (CE), período 1980-2016. 3c)

Distribuição de intensidade de evapotranspiração potencial ( $\mathrm{mm} / \mathrm{mês}$ ), estação Morada Nova (CE), período 2007-2016 3d) Distribuição de umidade relativa do ar, estação Morada Nova (CE), período 1980 a 2016.
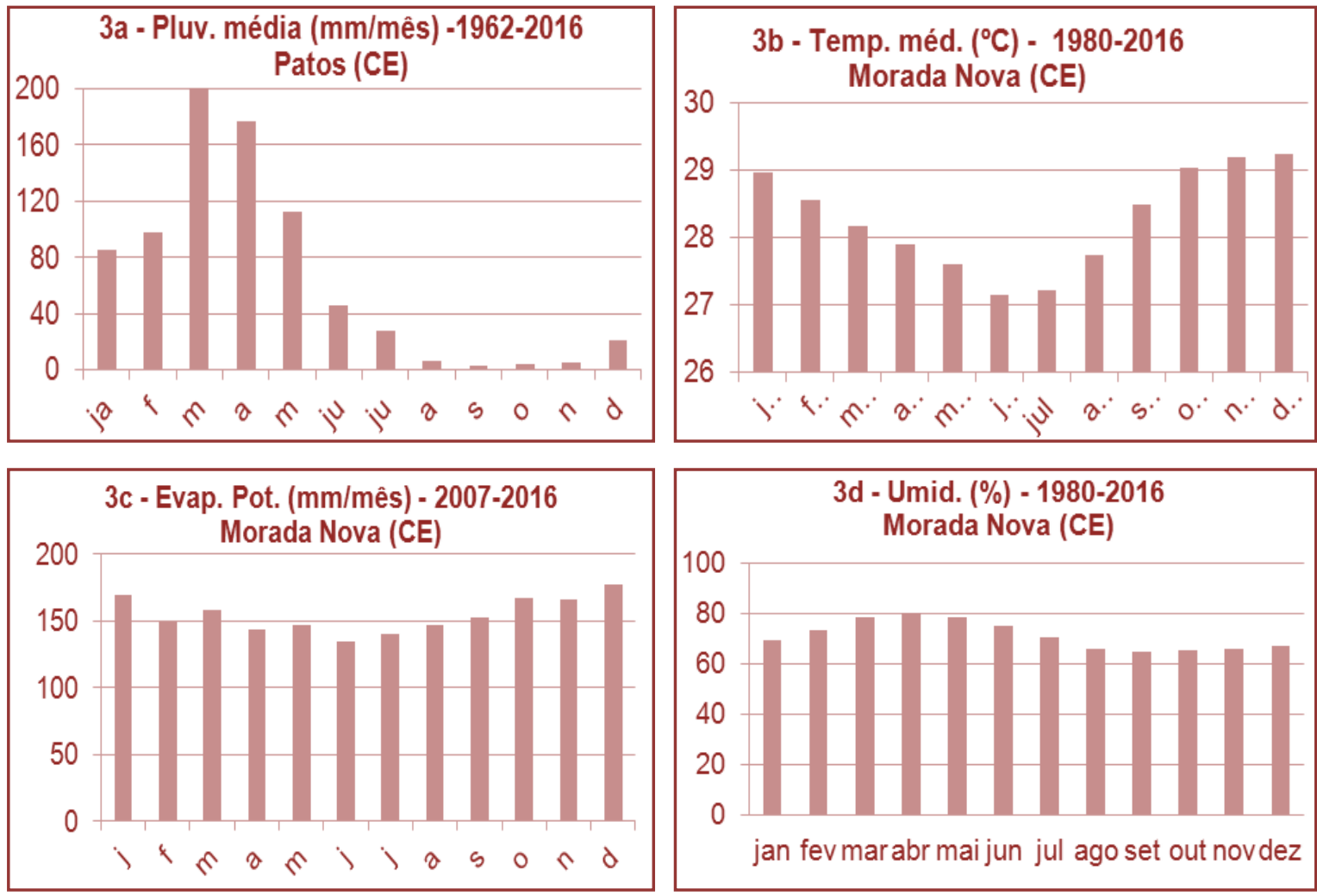

A presença de chuvas em período de tempo curto e concentrado promove intenso escoamento superficial. Além disso, somado com grande período de seca que promove a queda das folhas da vegetação, a chuva, quando chega, não encontra nenhum obstáculo. Desta forma o solo é castigado pelo sol (intenso nos períodos de seca e amplitude de temperatura) e pela chuva (no período concentrado e chuvoso), denominados intemperismo natural. Essa situação é propícia para ocorrência de erosão laminar e linear acelerada, uma vez que os materiais finos são transportados, restando rochas e pedras no terreno, o que caracteriza pré-condição ao processo de desertificação (BRANDÃO, 2014)

\section{RESULTADOS E DISCUSSÃO}

Na tabela 1 estão apresentados os resultados obtidos da análise das características fisiográficas da bacia em estudo. 
Tabela 1. Parâmetros fisiográficos determinados para a Bacia de Russas.

\begin{tabular}{|c|c|}
\hline Parâmetros & Dimensões \\
\hline Área de drenagem $\left(\mathrm{km}^{2}\right)$ & 163,95 \\
\hline Perímetro (km) & 65,05 \\
\hline Comprimento do rio principal (km) & 17,75 \\
\hline Fator de forma (Kf) & 0,56 \\
\hline Coeficiente de compacidade (Kc) & 1,42 \\
\hline Tempo de concentração (min) & 2033,39 \\
\hline Ordem dos cursos d'água & $3^{\mathrm{a}}$ ordem \\
\hline Densidade de drenagem $\left(\mathrm{kmkm}^{2}\right)$ & 0,60 \\
\hline Declividade média da bacia $(\mathrm{m} / \mathrm{m})$ & 0,0323 \\
\hline Elevação média da bacia (m) & 209,49 \\
\hline Declividade do álveo S1 (m/m) & 0,0037 \\
\hline Declividade do álveo S2 (m/m) & 0,0024 \\
\hline Declividade do álveo S3 (m/m) & 0,0027 \\
\hline Retângulo equivalente (km) & L 26,50/ l 6,02 \\
\hline
\end{tabular}

O fator de forma indica que a bacia possui um formato mais alongado, significando menor possibilidade de enchentes. Esta baixa tendência é confirmada também pelo coeficiente de compacidade, tendo em vista que o resultado encontrado foi acima da unidade, o que se deve ao formato irregular da bacia. Conforme a equação de Bransby-Willians, a bacia apresentou valor elevado de tempo de concentração, indicando que em condições normais de precipitação, a área não é propensa a inundações.

Segundo critério desenvolvido por Horton e modificado por Strahler, a ordem presente na bacia em estudo é o curso de água de 3ạ ordem, indicando que esta possui baixa ramificação.

Conforme Villela e Matos (1975), a densidade drenagem de uma bacia pode variar de $0,5 \mathrm{~km} / \mathrm{km}^{2}$ drenagem pobre a $3,5 \mathrm{~km} / \mathrm{km}^{2}$ - excepcionalmente bem drenadas. 0 resultado obtido foi de $0,60 \mathrm{~km} / \mathrm{km}^{2}$, o que representa uma eficiência de drenagem regular. Esse índice tem uma relação direta com o comportamento hidrológico das rochas. Rochas com maiores dificuldades de infiltração possibilitam melhores condições de escoamento superficial, elevando a densidade de drenagem (CHRISTOFOLETTI, 1980). Comparando então o valor obtido, o baixo índice da bacia de Russas, pode estar associado à presença de rochas permeáveis nas regiões de estudo.

0 grau de sinuosidade define a diferenciação dos tipos de canais que podem ser retos, meandrantes e anastomosados (CUNHA, 2011). 0 valor ficou um pouco acima da unidade, o que significa que a bacia apresenta baixo grau de sinuosidade, possuindo, portanto, canais mais retilíneos.

A declividade foi determinada através do Método das Quadrículas, conforme Villela e Matos (1975), e a partir de um MDE pelo sensor SRTM de 30 metros utilizando o software QGIS 2.14.5. Utilizando a equação que relaciona o produto do valor médio da declividade de cada intervalo de classe e a frequência correspondente, obteve-se uma declividade média de $0,0323 \mathrm{~m} / \mathrm{m}$ ou $3,23 \%$. 
Figura 4a) Mapa de declividade da Bacia de Russas 4b) Declividade Relativa - Bacia de Russas

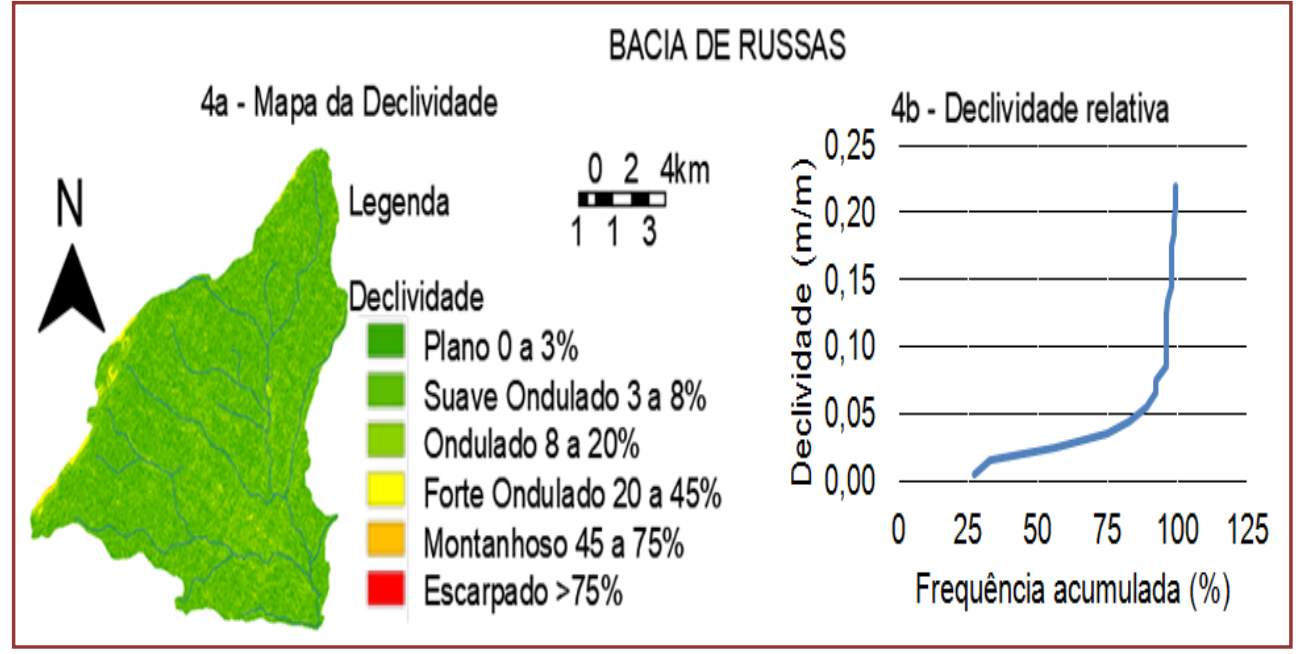

O gráfico das frequências acumuladas em função do limite inferior do intervalo de classe correspondente é mostrado a seguir (Figura 4a). 0 mapa gerado da declividade da bacia a partir de um MDE pelo QGIS 2.14.5 foi expressa em porcentagem, conforme classificação da Embrapa (Figura 4b), predominando a declividade como de relevo plano ( 0 a $3 \%$ ) e suave plano (3 a 8\%).

0 valor da declividade média de $0,0323 \mathrm{~m} / \mathrm{m}$ foi condizente com o relevo plano e suave ondulado da bacia de Russas. Essa declividade resulta numa redução dos picos de enchentes devido à baixa velocidade do escoamento. Revela ainda, uma baixa suscetibilidade à erosão. Portanto, pode-se considerar a bacia em estudo como área de baixa fragilidade ambiental aos processos erosivos em toda a sua extensão. Tais características não apresentam fortes restrições à infiltração da água da chuva e consequente abastecimento dos lençóis. A declividade pode mostrar uma baixa atividade no transporte de sedimentos, já que essa variável é considerada característica diretamente ligada aos processos de transporte, deposição e sedimentação das partículas do solo.

Para traçar a curva hipsométrica foi utilizado um software acoplado ao QGIS, chamado SAGA GIS. Além disso, utilizou-se também o software QGIS para a elaboração do Mapa Hipsométrico pelo MDE.

A bacia de Russas apresenta variações de altitude entre a seção de exutório e o seu ponto mais alto de cerca de $43 \mathrm{~m}$ a 268m (Figura 5a) o que, baseado nas informações de Woodcock (1976), poderá acarretar diferenças na temperatura média de aproximadamente $1,5^{\circ} \mathrm{C}$. As possíveis variações de precipitação anual serão mais significativas, o que trará consequências diretas sobre o deflúvio médio (VILELLA \& MATTOS, 1975).

Para a construção gráfica da curva hipsométrica foi considerado os termos da porcentagem da área de drenagem da bacia que se encontra acima (ou abaixo) das várias elevações (Figura 5b).

Figura 5a) Mapa Hipsométrico. 5b) Curva hipsométrica

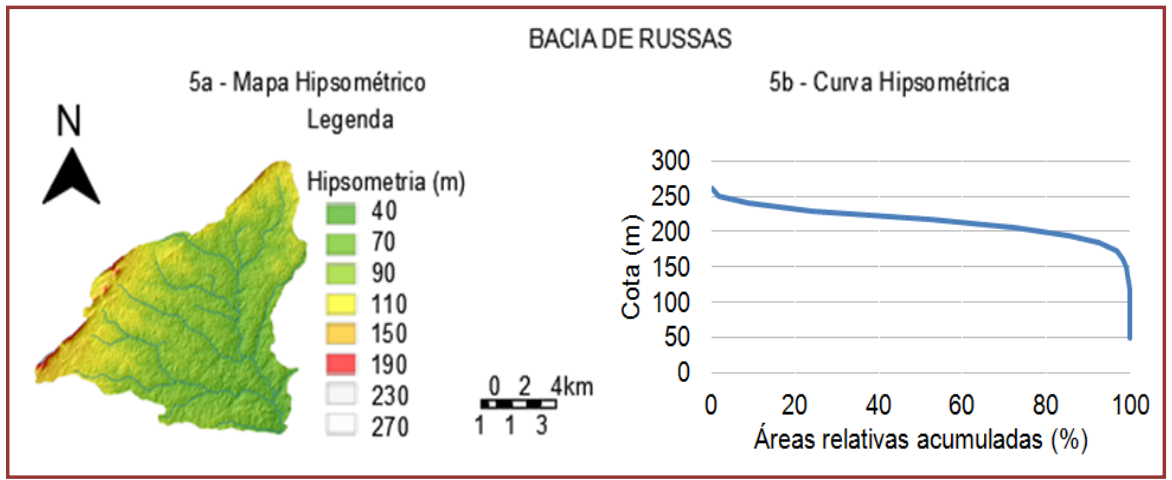


Além da variação da altitude dada pela curva hipsométrica, outra informação que pode ser obtida é a elevação média da bacia. Este índice exerce importante influência sobre a quantidade de radiação que a bacia recebe, e consequentemente, influencia a precipitação, temperatura, perdas de água por evaporação e transpiração e por consequência, sobre o deflúvio médio. Relaciona-se a elevação média entre duas curvas de nível consecutivas e as áreas entre as curvas de nível sobre a área total. 0 resultado obtido foi de $209,49 \mathrm{~m}$.

Com relação às características do curso d'água principal, o rio principal possui comprimento de 17,75 km e declividade média (S1) de $0,0037 \mathrm{~m} / \mathrm{m}$, além de pouco sinuoso, conforme verificado pelo índice de sinuosidade.

A declividade S1 não representa o desenvolvimento real do curso d'água, pelo fato de considerar somente os pontos extremos. A declividade média racional (S2) foi $0,0024 \mathrm{~m} / \mathrm{m}$, o que propicia escoamento mais lento com picos distribuídos em formato de patamar.

A declividade equivalente constante (S3) possibilita o melhor detalhamento do escoamento e do tempo de percurso da água ao longo da extensão do perfil longitudinal. É calculada pela média harmônica ponderada da raiz quadrada das declividades dos diversos trechos retilíneos, sendo o peso a extensão de cada trecho, resultando numa declividade equivalente constante (S3) de 0,0027 m/m.

As declividades do curso d'água principal calculadas pelos 3 métodos apresentam-se com valores similares (baixa declividade), sendo os valores S2 e S3 os mais próximos. Com tais características, ao longo de seu traçado devem predominar baixas velocidades de fluxo, indicando menor escoamento de água e maior tempo de permanência da água no canal.

Incorporando essa informação com a densidade de drenagem da bacia, tem-se que o curso d'água principal da referida bacia caracteriza-se em regime crítico, ou seja, baixa velocidade e média/baixa profundidade, relacionada com a regular e pobre eficiência de drenagem.

Por fim, foi obtido o retângulo equivalente elaborado segundo Villela e Matos (1975). Foram calculados os lados do retângulo e utilizou-se o ábaco, que relaciona o Coeficiente de compacidade (KC), com $\mathrm{L} / \sqrt{\mathrm{A}}$. 0 lado maior do retângulo equivalente (L) obtido foi $26,50 \mathrm{~km}$ e o lado menor (l) de 6,02km. Através desse parâmetro é possível fazer uma análise quanto à suscetibilidade a enchentes. Quanto mais retangular for 0 seu formato, indica que a bacia é mais estreita e alongada, p, portanto, menos possibilidade de uma chuva cobrir toda a sua área (BORSATO; MARTONI, 2004). 0 resultado corrobora as informações obtidas com as análises dos parâmetros anteriores no que se refere às respostas da área estudada a eventos de precipitação, pois segundo o retângulo equivalente a bacia é menos sujeita a enchentes.

\section{CONCLUSÕES}

Com relação ao fator de forma e ao coeficiente de compacidade, a bacia de Russas apresenta formato alongado, implicando em menor predisposição à enchentes e um maior tempo de concentração da água da chuva no seu território. As declividades do curso d'água principal calculadas apresentam-se com valores baixos, o que caracteriza baixa velocidade de fluxo, indicando menor escoamento de água e maior tempo de permanência da água no canal.

A baixa densidade de drenagem demonstra baixo grau de desenvolvimento do sistema de drenagem da bacia hidrográfica, indicando a presença de solos permeáveis e relevo pouco dissecado e pouco declivoso. A declividade média de 3,23\% indica que a bacia de Russas tem baixa susceptibilidade erosiva decorrente do escoamento hídrico superficial. Entretanto, de acordo com as características do tipo de solo, a região pode apresentar processos erosivos que, juntamente com outros aspectos, como a ação antrópica, podem potencializar esse processo.

Com relação à cobertura vegetal, há a presença de Savana Estépica Arborizada. Uma parte da bacia é utilizada para agropecuária, que pode favorecer os processos de erodibilidade. Assim, faz-se necessário o manejo desenvolvido para que haja controle do processo de erosão, no caso da agricultura e rotação de cultura para pecuária.

O clima da região é quente com estações definidas (quente/seca - inverno e quente/úmido - verão). Nos períodos de chuvas curtas e concentradas, ocorre o escoamento superficial. A partir desse processo, com a queda das folhas da vegetação no período de seca e o solo totalmente exposto à radiação solar, a chuva, quando chega, não encontra nenhum obstáculo. Esse conjunto de situações é propício para ocorrer erosão 
laminar e linear acelerada, o que caracteriza pré-condição ao processo de desertificação, bastante comum no sertão nordestino.

Contudo, a análise realizada na bacia é de caráter unicamente descritivo e que precisa ser complementada por análises hidrológicas e balanços hídricos mais detalhados. A variabilidade de chuva, o tipo de chuva (intensidade/duração) e a análise histórica das vazões são imprescindíveis.

\section{AGRADECIMENTOS}

Os autores agradecem à Universidade Federal de Mato Grosso do Sul (UFMS) pelo auxílio financeiro disponibilizado para a apresentação da pesquisa no evento.

\section{REFERÊNCIAS}

[1] Agência Nacional De Águas (Ana). "HidroWeb - Sistema de Informações Hidrológicas": Séries Históricas. 2017. Disponível em: <http://hidroweb.ana.gov.br/HidroWeb.asp>. Acesso em: 28 jul. 2017.

[2] Brandão, Ricardo de Lima. "Geodiversidade do estado do Ceará / Organização Ricardo de Lima Brandão \& Luís Carlos Bastos Freitas”. Fortaleza: CPRM, 2014. 214 p. ISBN 978-85-7499-140-5

[3] Borsato, Fabiano; Martoni, Astrid Meira. "Estudo da fisiografia das bacias hidrográficas urbanas no Município de Maringá", Estado do Paraná - DOI: 10.4025/actascihumansoc.v26i2.1391. Acta Scientiarum. Human and Social Sciences, 2008. v. 26, n. 2, p. 273-285.

[4] Chagas, César da Silva et al . Atributos topográficos na diferenciação de Argissolos. Rev. Bras. Ciênc. Solo, Viçosa , v. 37, n. 6, p. 1441-1453, Dec. 2013 ou Chagas, César da Silva, Fontana, Ademir, Carvalho Junior, Waldir de, \& Caires, Sandro Marcelo de. (2013). Atributos topográficos na diferenciação de Argissolos. Revista Brasileira de Ciência do Solo, 37(6), 1441-1453.

[5] Christofoletti, Antônio. "Geomorfologia". 2. ed. rev. e ampl. São Paulo, SP: Blücher, 1980-2011. 188 p. ISBN 85-212-0130-3.

[6] Cunha, Sandra Baptista da; Guerra, Antonio José Teixeira (Org.). "Geomorfologia: exercícios, técnicas e aplicações". 5. ed. Rio de Janeiro, RJ: Bertrand Brasil, 2010-2011. 343 p. ISBN 978-85-286-0548-8.

[7] Empresa Brasileira De Pesquisa Agropecuária (Embrapa) "Ibge-Embrapa- Mapa de Solos do Brasil. - Escala 1:5.000.000". Rio de Janeiro: IBGE, 2001. Disponível em: <http://www.dpi.inpe.br/Ambdata/mapa_solos.php>. Acesso em: 22 jul. 2017.

[8] Garcez, Lucas Nogueira; Alvarez, Guillermo Acosta. "Hidrologia". 2. ed. rev. atual. São Paulo, SP: Blücher, c1988-2012. 291 p. ISBN 85-212-0169-9.

[9] Grego, Célia Regina; Coelho, Ricardo Marques; Vieira, Sidney Rosa. Critérios morfológicos e taxonômicos de Latossolo e Nitossolo validados por propriedades físicas mensuráveis analisadas em parte pela geoestatística. "Rev. Bras. Ciênc. Solo", Viçosa, v. 35, n. 2, p. 337-350, Apr. 2011.

[10] Instituto Brasileiro De Geografia e Estatística (IBGE). "Cidades". Rio de Janeiro: IBGE. 2017. v.4.1.15.2. Disponível em: <https://cidades.ibge.gov.br/v4>. Acesso em: 26 jul.. 2017.

[11]

"Distribuição Regional da vegetação natural". Rio de Janeiro: IBGE. 2004. Disponível em: <ftp://geoftp.ibge.gov.br/informacoes_ambientais/vegetacao/mapas/brasil/vegetacao.pdf>. Acessso em: 29 jul. 2017.

[12] "Mapa de clima do Brasil". Rio de Janeiro: IBGE. 2002. Disponível em: <ftp://geoftp.ibge.gov.br/informacoes_ambientais/climatologia/mapas/brasil/clima.pdf>. Acesso em: 29 jul. 2017.

[13]

"Russas": Infográficos - despesas, receitas orçamentárias e PIB. Rio de Janeiro: IBGE. 2016. Disponível em: <http://cod.ibge.gov.br/3PG0>. Acesso em: 29 jul. 2017.

[14] Instituto Nacional De Meteorolgia (INMET). "Dados históricos": DBMEP - Banco de Dados Meteorológicos para Ensino e Pesquisa. 2017 Disponível em: <http://www.inmet.gov.br/portal/index.php?r=bdmep/bdmep>. Acessado em: 27 jul. 2017.

[15] Lima, Antonio Agostinho Cavalcanti; Oliveira, Francisco Nelsieudes Sombra; Aquino, Antonio Renes Lins de. "Limitações do uso dos solos do Estado do Ceará por suscetibilidade à erosão. Fortaleza: Embrapa Agroindústria Tropical", 2002. 19p. ISSN: 1677-1915 (Embrapa Agroindústria Tropical. Documentos, 54).

[16] Menezes, Sebastião de Oliveira. "Rochas: manual fácil de estudo e classificação". Oficina de Textos, 2013. 
[17] Porto, Rubem La Laina; Zahed Filho, Kamel; Da Silva, Ricardo Martins. "Bacias Hidrográficas" - PHD 307 Hidrologia Aplicada. Escola Politécnica da USP, Departamento de Engenharia Hidráulica e Sanitária, São Paulo, SP, 1999, 35p.

[18] Russas. Prefeitura Municipal de Russas. "Sobre Russas". 2017. Disponível em: <http://russas.ce.gov.br/sobre-russas/>. Acesso em: 26 jul. 2017.

[19] Schiavetti, Alexandre; Camargo, Antonio Fm. "Conceitos de bacias hidrográficas: teorias e aplicações". Editus, 2002.

[20] Sistema De Geociências Do Serviço Geológico Do Brasil - CPRM. 2017. "Sistema de Geociências (GeoSGB) Arquivos vetoriais e raster". Disponível em:<http://geosgb.cprm.gov.br/>. Acesso em: 28 jul. 2017.

[21] Sistema Nacional De Informações Sobre Recursos Hídricos (SNIRH). "HidroWeb - Sistema de Informações Hidrológicas". 2017. Disponível em: <http://www.snirh.gov.br/hidroweb/>. Acesso em: 28 jul. 2017.

[22] Sociedade Portuguesa De Inovação (SPI). “Programa de desenvolvimento urbano de pólos regionais - Vale do Jaguaribe e Vale do Acaraú: Atualização do plano de desenvolvimento regional”. Oikos Pesquisa Aplicada, 2016. 469 p.

[23] Teodoro, V. L. I.; Teixeira, D.; Costa, D. J. L.; Fuller, B. B. "O conceito de bacia hidrográfica e a importância da caracterização morfométrica para o entendimento da dinâmica ambiental local". Revista Uniara, v.20, p.137-157, 2007.

[24] Tucci, Carlos E. M. "Hidrologia": ciência e aplicação. 2. ed. Porto Alegre, RS: Ed. da Universidade, ABRH, 1997. 943 p. ISBN 85-7025-298-6

[25] Villela, Swami Marcondes; Mattos, Arthur. "Hidrologia aplicada". São Paulo, SP: McGraw-Hill do Brasil, 1975. $245 \mathrm{p}$.

[26] Woodcock, R. G. "Weather and Climate". Estover: MacDonald \& Evans, 1976. 


\section{Capítulo 8}

Modelagem hidrogeotécnica de áreas susceptíveis aos movimentos de massa em escala municipal usando o TauDem

\section{Cleverson Alves de Lima \\ Lais Emily Assis \\ Eduardo Antônio Gomes Marques \\ Sady Júnior Martins da Costa de Menezes \\ Getúlio Fonseca Domingues}

Resumo: A urbanização combinada à alta densidade populacional caracterizam os assentamentos atuais, sendo um fenômeno social, econômico e ambiental importante, que compromete o planejamento e gestão das cidades. Assim sendo, a percepção dos riscos socioambientais torna-se relevante, devendo, integrar ações estruturantes e o planejamento para as cidades modernas. Este estudo, tem objetivo propor uma modelageem de uma base de informações que subsidiarão os estudos de desastres naturais, usando dados de perfilamento a laser (LiDAR) no município de Três Rios-RJ e parâmetros hidrológicos comporão o mapa de áreas susceptiveis ao risco de movimentos de massa, a nível municipal. 0 estudo explora, através de métodos determinísticos a questão da estabilidade quanto ao movimentos de massa, em análise macro quando submetido a chuvas intensas, fazendo uma associação com a topografia da região e ao tipo de ocupação urbana. Assim, mostra a importância do planejamento socioambiental para cidades com porte semelhante e em franco crescimento econômico, fornecendo informações detalhadas para subsidiar propostas de desenho urbano.

Palavras-Chave: Suscetibilidade; Estabilidade de taludes; TauDEM; Sensoriamento Remoto 


\section{INTRODUÇÃO}

Os desastres naturais constituem um tema cada vez mais presente no cotidiano das pessoas, independentemente destas residirem ou não em áreas de risco. Ainda que em um primeiro momento o termo nos leve a associá-lo com terremotos, tsunamis, erupções vulcânicas, ciclones e furacões, os Desastres Naturais contemplam, também, processos e fenômenos mais localizados tais como deslizamentos, inundações, subsidências e erosão, que podem ocorrer naturalmente ou induzidos pelo homem (TOMINAGA; SANTORO; AMARAL, 2009).

A UN-ISDR (2004) define desastre como "uma grave perturbação do funcionamento de uma comunidade ou de uma sociedade envolvendo perdas humanas, materiais, econômicas ou ambientais de grande extensão, cujos impactos excedem a capacidade da comunidade ou da sociedade arcar com seus próprios recursos. A ocorrência de um fenômeno geológico-geotécnico pode ou não gerar perdas e danos, sendo no primeiro caso acidente e no segundo de evento. A susceptibilidade de uma área com relação a determinado fenômeno geológico caracteriza a possibilidade de sua ocorrência (evento), enquanto que risco envolve a possibilidade de que um fenômeno (evento) seja acompanhado de danos e perdas (acidente), conforme mostrado na Erro! Fonte de referência não encontrada.. Vulnerabilidade significa o grau de perda de um dado elemento ou grupo de risco dentro de uma área afetada por um processo.

Tabela 2 - Conceito dos termos acidente, evento e risco Fonte: (CERRI; AMARAL, 1998)

\begin{tabular}{|l|l|}
\hline \multicolumn{1}{|c|}{ Termo } & \multicolumn{1}{c|}{ Conceito } \\
Acidente & $\begin{array}{l}\text { Fato já ocorrido, onde foram registradas consequências } \\
\text { sociais e econômicas (perdas e danos) }\end{array}$ \\
\hline Evento & $\begin{array}{l}\text { Fato já ocorrido, onde não foram registradas consequências } \\
\text { sociais e econômicas relacionadas diretamente a ele. }\end{array}$ \\
\hline Risco & Possibilidade de ocorrência de um acidente. \\
\hline
\end{tabular}

Os riscos podem ser classificados ainda como endógenos, associados aos processos geodinâmicos internos, tais como terremotos, vulcões, tsunamis etc; ou riscos exógenos, associados aos processos externos, tais como escorregamentos, erosão, subsidências, colapsos etc, como mostrado na Figura 1.

Figura 1- Classificação de riscos ambientais

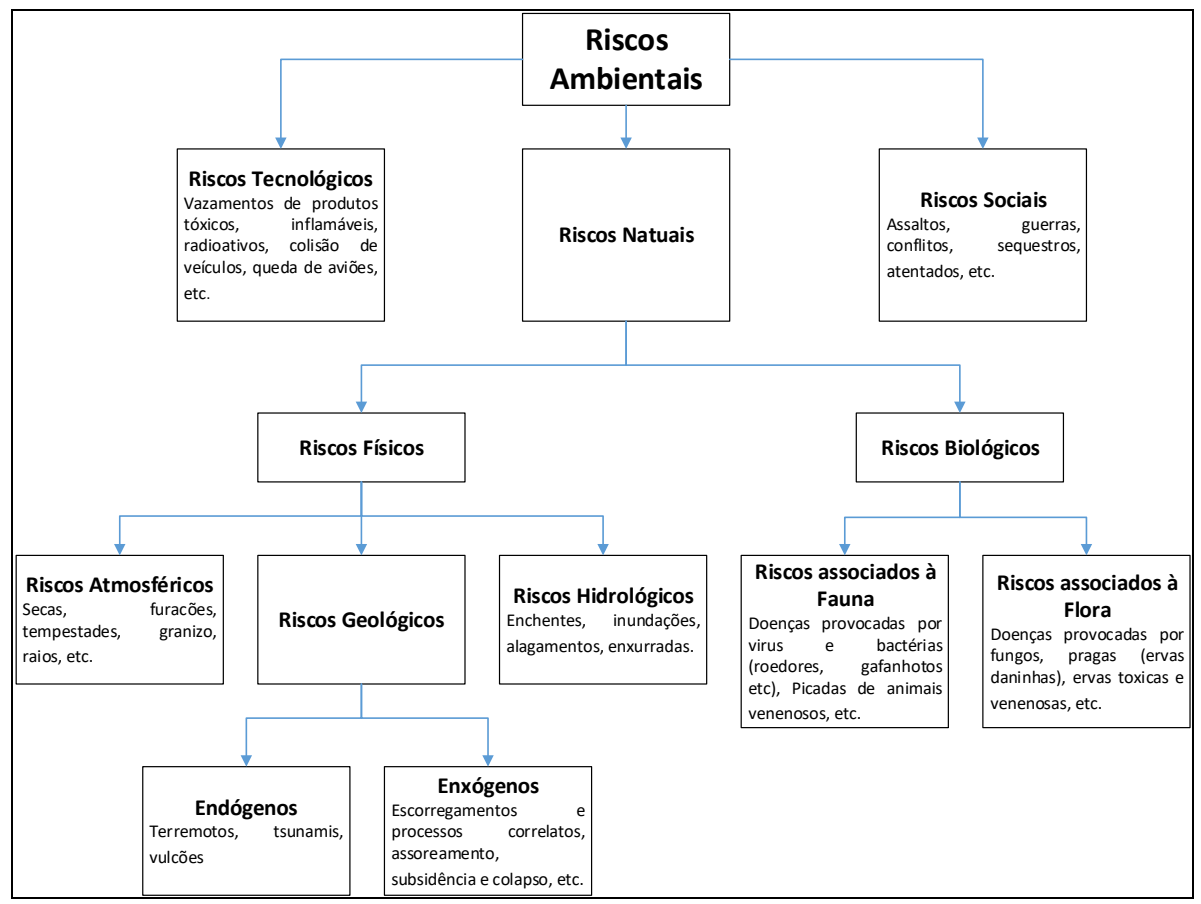


Entretanto, o foco de uma análise de suscetibilidade, deve estar pautada nos processos desencadeadores dos desastres, tornando o conhecimento e a avaliação do meio físico obrigatório, como forma de prever o comportamento das áreas envolvidas. No entanto, estes comportamentos são variáveis, dependendo de características do relevo, tipo de solo, tipo litológico do substrato, forma de uso e ocupação, além da climatologia local.

As ações humanas, tendem a amplificar a gravidade dos desastres naturais, produzindo ameaças em áreas estáveis onde não existiam tais condições. Isto é devido ao realização de modificações na área, mediante a construção civil, manejo inadequado, desfiguração ambiental, sem considerar os processos dinâmicos naturais. Portanto, a importância que tem a percepção da vulnerabilidade ambiental frente a suscetibilidade e frente aos eventos de risco, dá uma dimensão que deve ser considerada para o desenvolvimento regional, fortalecendo os mecanismos de enfrentamento das causas e consequências, minimizando as perdas econômicas, sociais e ambientais.

Assim, como mencionado por Marcelino (2008), torna-se menos conflituoso classificar os desastres quanto à sua origem, seja naturais e humanos, tendo como referencial o fenômeno que desencadeou o processo. Ou seja, os naturais seriam os disparados por fenômenos naturais de grande intensidade e os humanos pelas ações ou suas omissões. Outras proposições foram feitas para uma classificação objetiva dos desastres naturais, tal como a proposta apresentada por Kobiyama (2006), que faz uma avaliação com base na intensidade do fenômeno, como forma de planejar as ações necessárias para ação imediata e recuperação pós evento, ficando as situações conforme Tabela 3.

\begin{tabular}{|c|c|c|}
\hline Nível & Intensidade & Situação \\
\hline I & $\begin{array}{l}\text { Desastres de pequeno porte, também } \\
\text { chamados de acidentes, em que os } \\
\text { impactos causados são pouco } \\
\text { importantes e os prejuízos pouco } \\
\text { vultosos. (prejuízo menor que 5\% do PIB } \\
\text { municipal) }\end{array}$ & $\begin{array}{l}\text { Facilmente superável com os } \\
\text { recursos do próprio } \\
\text { município. }\end{array}$ \\
\hline II & $\begin{array}{l}\text { De média intensidade, em que os } \\
\text { impactos são de alguma importância e os } \\
\text { prejuízos são significativos, embora não } \\
\text { sejam vultosos. (prejuízos entre } 5 \% \text { e } \\
10 \% \text { do PIB municipal) }\end{array}$ & $\begin{array}{l}\text { Superável pelo município, } \\
\text { desde que envolva uma } \\
\text { mobilização e administração } \\
\text { especial. }\end{array}$ \\
\hline III & $\begin{array}{l}\text { De grande intensidade, com danos } \\
\text { importantes e prejuízos vultosos. } \\
\text { (prejuízo entre 10\% e 30\% do PIB } \\
\text { municipal) }\end{array}$ & $\begin{array}{l}\text { A situação de normalidade } \\
\text { pode ser restabelecida com } \\
\text { recursos locais, desde que } \\
\text { complementados com } \\
\text { recursos estaduais e federais. } \\
\text { (Situação de Emergência - SE) }\end{array}$ \\
\hline IV & $\begin{array}{l}\text { De grande intensidade, com impactos } \\
\text { muito significativos e prejuízos muito } \\
\text { vultosos. (prejuízos maiores que } 30 \% \text { do } \\
\text { PIB municipal) }\end{array}$ & $\begin{array}{c}\text { Não é superável pelo } \\
\text { município, sem que receba } \\
\text { ajuda externa. Eventualmente } \\
\text { necessita de ajuda } \\
\text { internacional. (Estado de } \\
\text { Calamidade Pública - ECP) }\end{array}$ \\
\hline
\end{tabular}

Uma política para a gestão de desastres deve prever que medidas de prevenção e preparação sejam adicionadas durante a formação ou reconstrução de uma área, aliada à uma política de desenvolvimento, a fim de se reduzir os impactos dos futuros eventos.

Considerando o cenário atual, a administração publica de posse de ferramentas de suporte a decisão e dados confiáveis, obrigam-se a um replanejamento das respostas ante futuras situações de riscos naturais, podendo seguir por uma redistribuição das habitações vulneráveis; planos de prevenção e mitigação como forma de minimizar os efeitos dos eventos futuros; associado ao fortalecimento e integração dos sistemas de defesa civil locais e nacionais, compartilhando meios e recursos.

Com isso, apresenta-se neste trabalho uma proposta de modelagem hidrogeotécnica, em escala municipal, a nível qualitativo, quanto a suscetibilidade de movimentos de massa aplicados as áreas urbanas ocupadas, considerando para isso, os cenários de uso do solo e o seu diagnóstico. Esta proposta em desenvolvimento, visa indicar as áreas susceptíveis e posteriormente analisar as possíveis consequências 
decorrentes de movimentos de massa em um município de médio porte, em franca expansão e industrialização, e como a falta de políticas publicas de planejamento urbano que podem acarretar ao aparecimento de zonas de risco evitáveis. Desta maneira, os produtos deste trabalho de pesquisa visam contribuir ao desenvolvimento local, integrado e sustentável inseridos no Plano Nacional de Prevenção a Desastres Naturais, com o fornecimento de cartas, mapas e ferramentas de apoio as decisões dos agentes publicos. Ou seja, possam auxiliar e direcionar as políticas publicas adequadas ligadas aos riscos geológico-geotécnicos.

\section{MATERIAIS E MÉTODOS}

\subsection{ESTUDO DE CASO}

O estudo foi realizado na cidade de Três Rios-RJ, a qual faz parte do Vale do Rio Paraíba do Sul, região Centro-Sul do estado do Rio de Janeiro, estando inserido no bioma Mata Atlântica. Como relatado por AGEVAP (2007), estima-se que a micreorregião possui grau de vulnerabilidade a erosão da ordem de 3.552 ha para classe muito alta, 5.084 ha para classe alta e 21.840 ha para classe média. Ou seja, a situação na qual o município esta inserido é de risco iminente.

A Figura 2, indica os limites municipais de Três Rios, no enquadramento geográfico de Latitude 227'4'12,60"S a 2209'52,87"S e Longitude 4315'23,33”W a 43"04'43,97”W, localizando-se na Região Hidrográfica RH-III, do médio Paraíba do Sul e possui criticidade para desastres entre médio e alta.

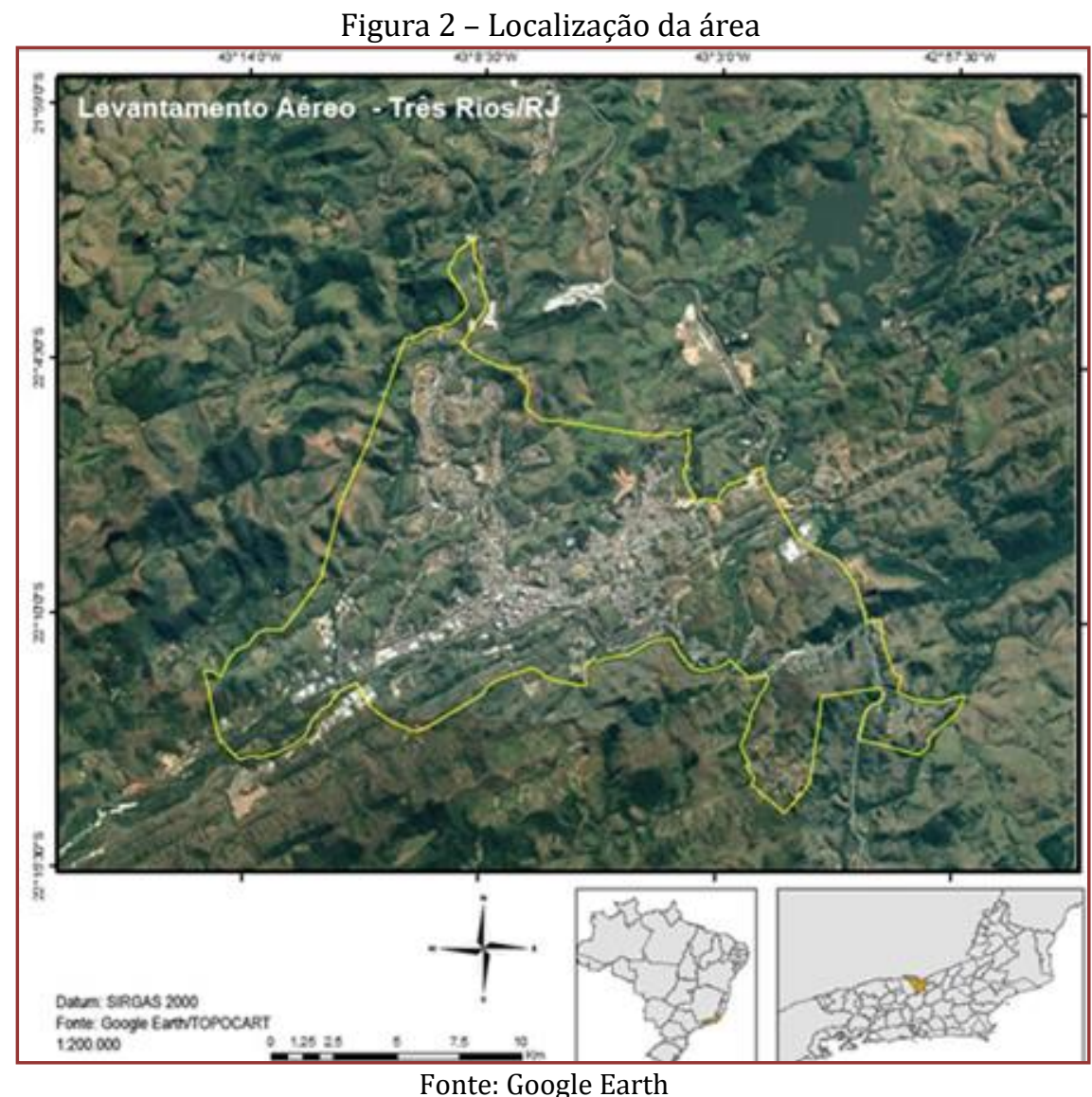

\subsection{MODELO DIGITAL DO TERRENO (MDT)}

O MDT foi gerado a partir de uma nuvem de pontos obtidos pelo perfilamento a laser (LiDAR), que após filtrados os pontos descartáveis (copas de árvores, postes, casas etc), restará uma base de dados com mais de 20 milhões de coordenadas X, Y, Z (Latitude, Longitude e Altitude). 0 perfilamento a laser, foi processado com resolução espacial de $10 \mathrm{~cm}$, abrangendo toda a área urbana do município, totalizando 35 $\mathrm{km}^{2}$. A densidade de pontos adotada no mapeamento foi de 2 ppm (pontos por metro quadrado), com 
objetivo de gerar mapas na escada 1:2000. 0 plano de voo considerou sobreposições laterais de $30 \%$ e longitudinais de $60 \%$ de modo a prevalecer a resolução requerida, conforme pode ser visto nas Figuras 3 e 4.

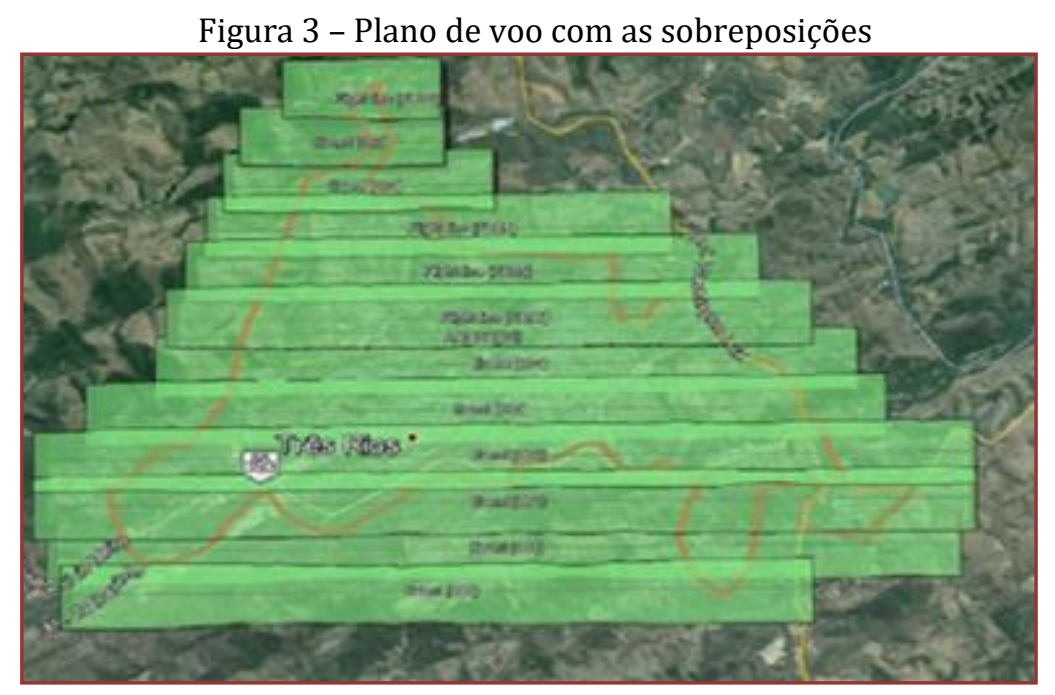

Figura 4 - Vista em 3D do plano de voo

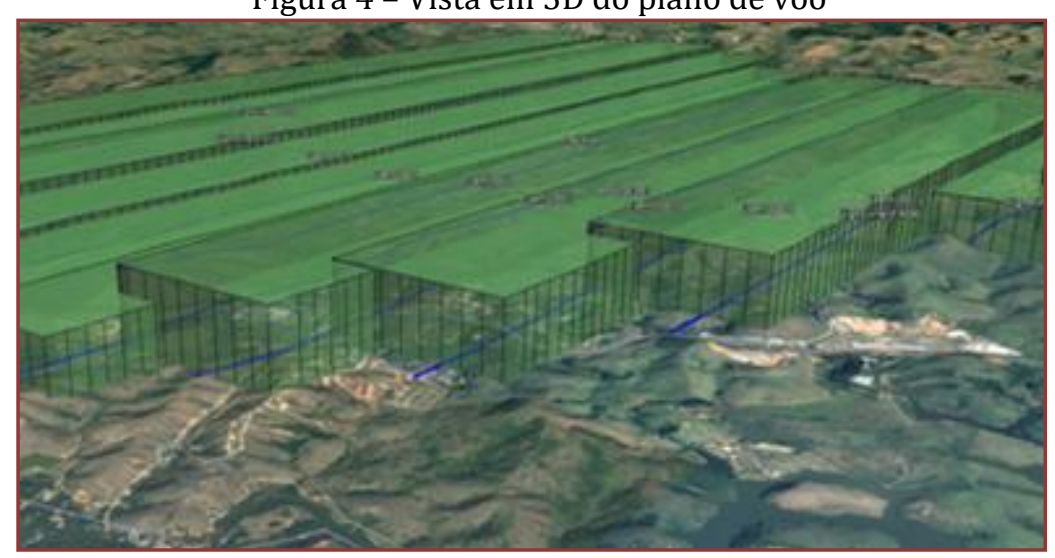

O voo foi realizado com apoio de campo através de receptores GNSS, pelo sistema de aerotriangulação que atenderam as exigências analíticas e semi analíticas.

\subsection{PROCESSAMENTO DOS DADOS}

Foram feitas parcerias com diversas instituições, no ambito estadual e federal, a fim de se acumular as informações básicas iniciais para o desenvolvimento dos estudos. Para isso, a Defesa Civil do Município de Três Rios, Defesa Civil do Estado do Rio de Janeiro, IBGE (Instituto Brasileiro de Geografia e Estatistica), FURNAS Centrais Elétricas, Universidades e a Prefeitura Municipal de Três Rios, viabilizaram suas base de dados contendo as diversas informações necessárias para a modelagem de risco a nível municipal, para o caso de Três Rios.

Do leque de informações disponível, foi adotado o Perfilamento a Laser (LiDAR) realizado na área urbana municipal, a fim de se classificar o tipo de uso do solo urbano e obter os parâmetros topográficos (Figura 5), obtendo como produto o Modelo Digital de Terreno (MDT) usando o software ArcGIS 10.3.1 (Figura 6). Em seguida, foi feito o cruzamento com a hidrografia, vegetação e pontos de interesse, limitando-os a área em questão, usando a base de dados disponibilizada pelo IBGE, na escala 1:25.000. Após este processamento, como novo produto, foi obtido um mapa indicando a rede de drenagem municipal, que considera o relevo local e as diversas nuances das áreas ocupadas. Como resultado desta análise, traçou-se 
um perfil hidrogeotécnico superficial da área, que forneceram as áreas de maior suscetibilidade ao movimento de massa.

Figura 5 - Núvem de pontos do LiDAR após a remoção de dados desnecessários

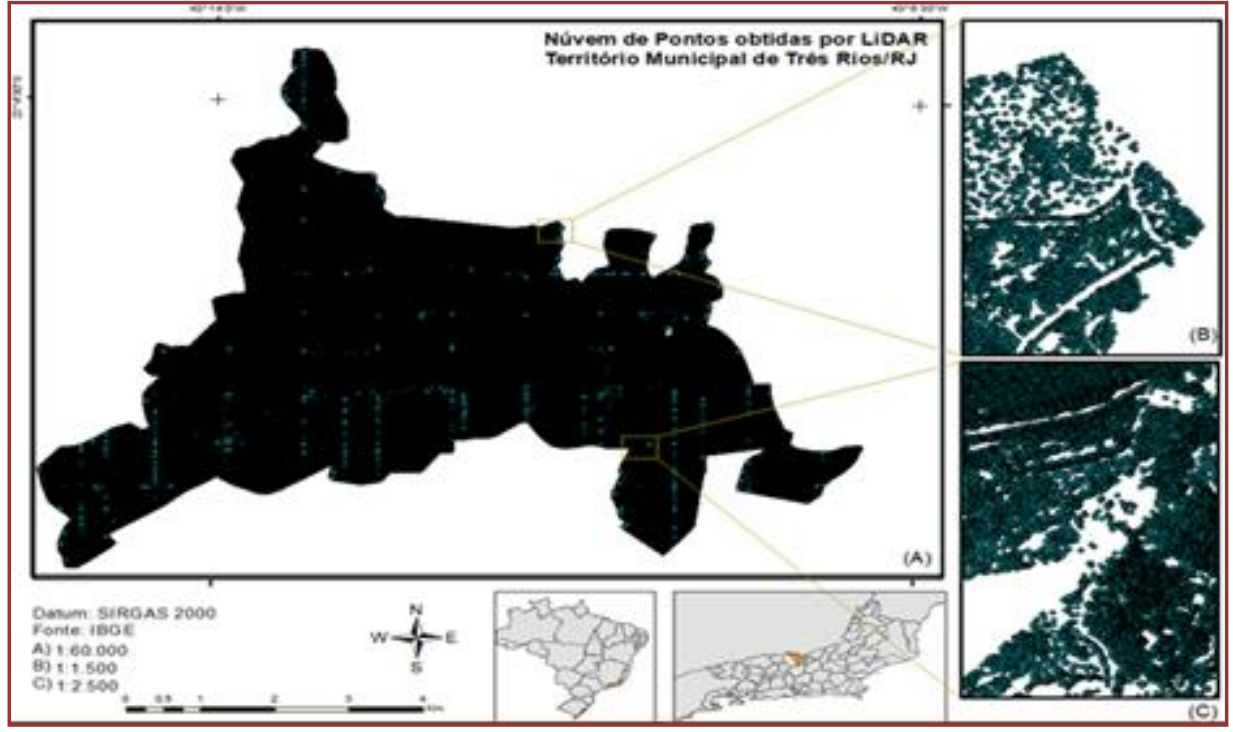

Figura 6 - MDT da cidade de Três Rios

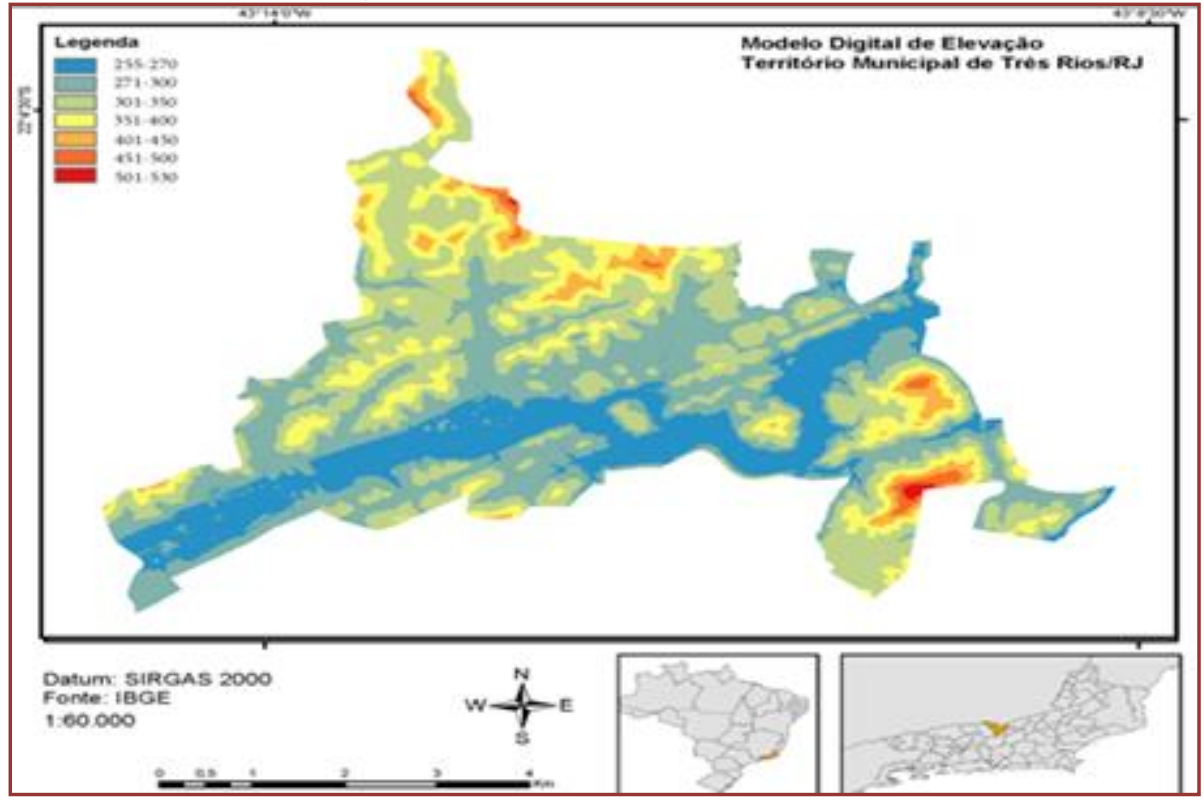

Com estes resultados em mãos, pôde-se caracterizar a área de maior risco considerando a sua inclinação, acumulo de chuvas intensas na bacia hidrográfica e possíveis áreas atingidas por escorregamento utilizando a ferramenta TauDEM (Terrain Analysis - Digital Elevation Models). Esta ferramenta permite realizar uma análise integrada, de toda a superfície e subsuperfície, diferente de outras ferramentas encontradas no mercado que fazem avaliações pontuais. Estes mapas subsidiarão o poder publico a tomar medidas de prevenção, mitigação e gestão socio-ambiental urbana.

A Figura 7 resume o processamento de dados utilizando a ferramenta proposta até se obter as áreas com maiores probabilidades de incidência, baseados nos parâmetros de relevo, hidrológicos e geotécnicos. Embora seja de fácil entendimento. A ferramenta, como um todo, adota e depende da inclinação do terreno, preenchendo os dados espúrios ou as descontinuidades, gerando, como produto final um modelo digital hidrologicamente condicionado. Esta suavização dos pontos não contínuos evita que o processo de 
drenagem seja encaminhado para este ponto, chamados de depressões espúrias, incorrendo em erros no modelo.

Destaca-se o algorítmo Do presente na ferramenta TauDEM, que dispersa o fluxo de água proporcionalmente de acordo com a inclinação da célula adjacente, ou seja, quando comparado a outras metodologias, esta ferramenta distribui os fluxos pluviais aproximando com a realidade encontrada na natureza, ilustrado na Figura 8. Sua vantagem frente ao método D8, tradicional, é que o fluxo de descarga não fica limitado aos 8 caminhos adjacentes à célula e possíveis de escoamento, ampliando a possibilidade, ja que a análise é feita célula a célula e o fluxo disperso da mesma forma. 0 cálculo do fluxo proporcional dado pela metodologia Dœ, determina as direções e usa as informações de inclinação descendente. Como subprodutos esta ferramenta fornece a direção de fluxo Dœ (Flow Direction) e o grid de inclinação do talude Do (Slope Grid), que possui a inclinação considerando a razão queda/distância, ou seja, a tan $\theta$ (rad).

Figura 7 - Diagrama de processamento das áreas de risco a movimentos de massa

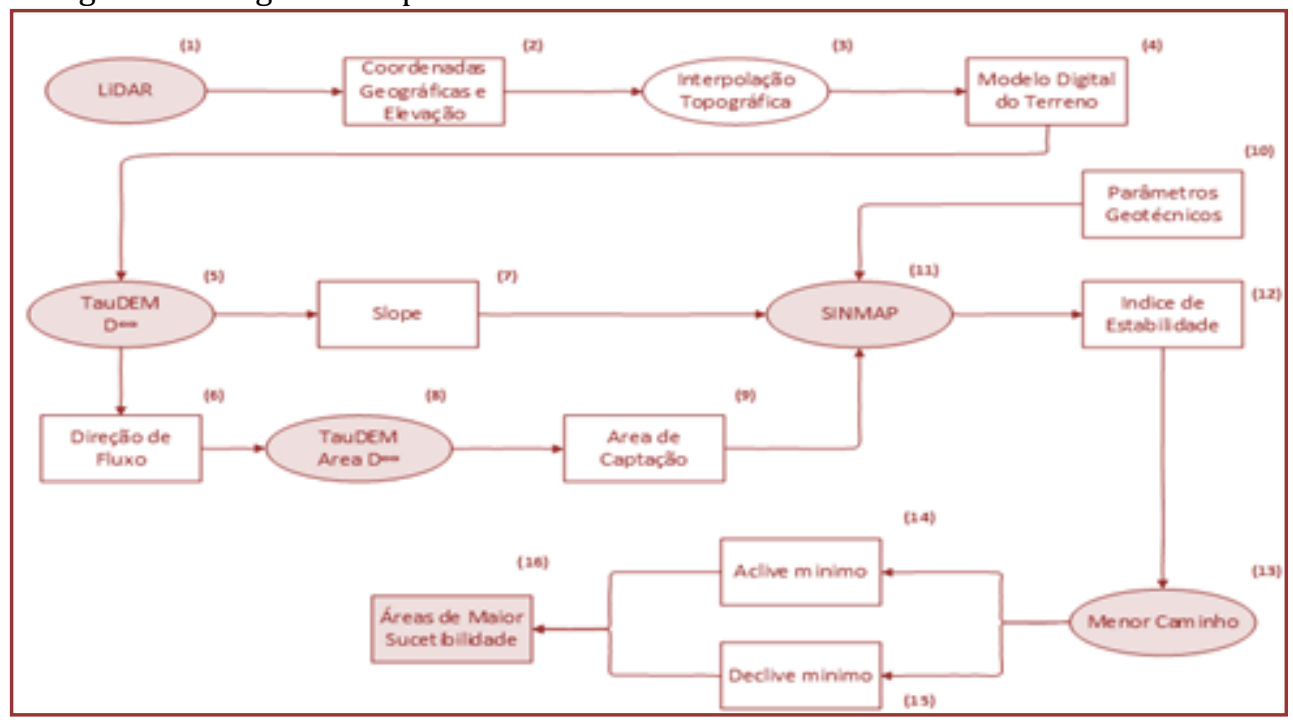

Figura 8 - (a) Representação da distribuição proporcionaldo fluxo no campo (Tarboton, 1997); (b) Representação do caminho de drenagem pelo método D8; e, (c) Representação da dispersão de fluxo pelo

(a)

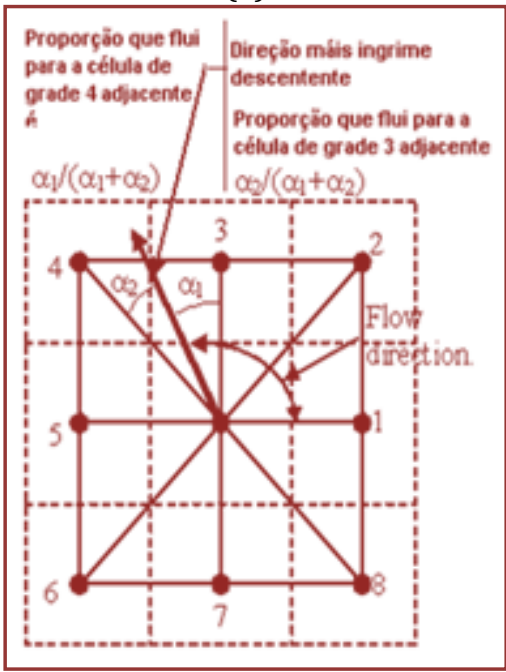
método Do

(b)

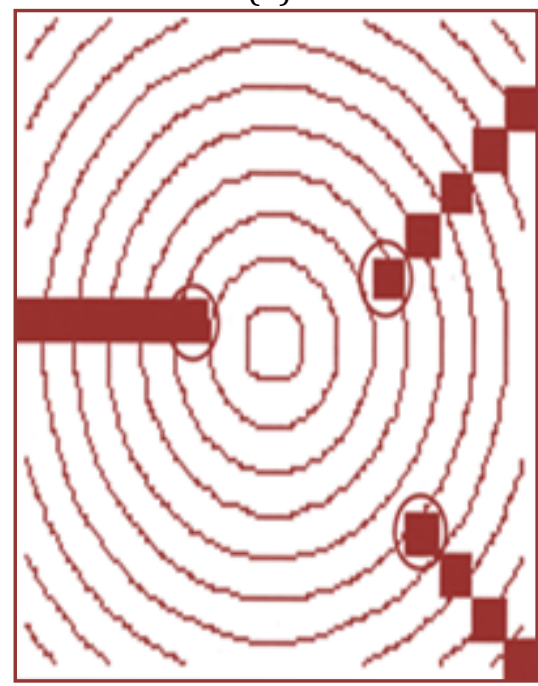

(c)

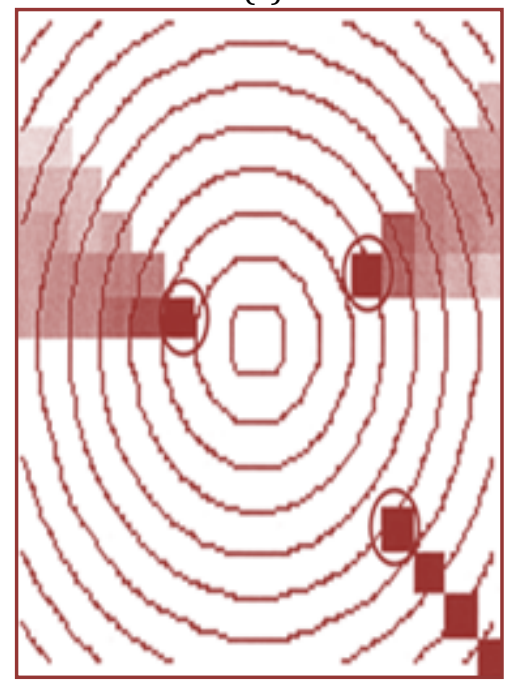


Todos os subprodutos gerados, pela ferramenta são processados juntamente com os parâmetros geotécnicos e hidrológicos dentro do SINMAP/TauDEM (Stability Index Mapping), obtendo assim um mapa com Índice de Estabilidade do Terreno que considera as propriedades físicas da área avaliada. Podese fazer um processamento utilizando estes parâmetros padrão para uma análise preliminar, e posteriormente, utilizar os parâmetros reais da região.

Nesta etapa, serão feitas uma avaliação dos parâmetros geológicos-geotécnicos do solo subsuperficial, buscando formular de formula rápida, como produto final, um mapa com as áreas passíveis de ocorrências ou de alto risco, será confeccionado, ampliando o entendimento dos agentes publicos quanto aos riscos de desastres.

\section{RESULTADOS E DISCUSSÃO}

0 processamento de dados indicou os pontos de maior probabilidade de ocorrência de movimentos de massa considerando a intensidade de chuvas, a rede de drenagem superficial e parâmetros geotécnicos.

Partindo-se da base de dados obtida dos diversos órgãos, buscou-se entender o direcionamento das águas pluviais dentro do contexto urbano, modelando as redes de fluxo superficiais e zonas de concentração destas águas. Para isso, utilizou-se o algoritmo Do presente na ferramenta TauDEM, que distribuiu os fluxos de água proporcionalmente de acordo com a inclinação de cada célula. Na Figura 9, é apresentado o direcionamento de fluxo da rede de drenagem municipal e, na Figura 10, apresentado os caminhos que cada fluxo de drenagem percorre:

Figura 9 - Vetor fluxo de drenagem superficial

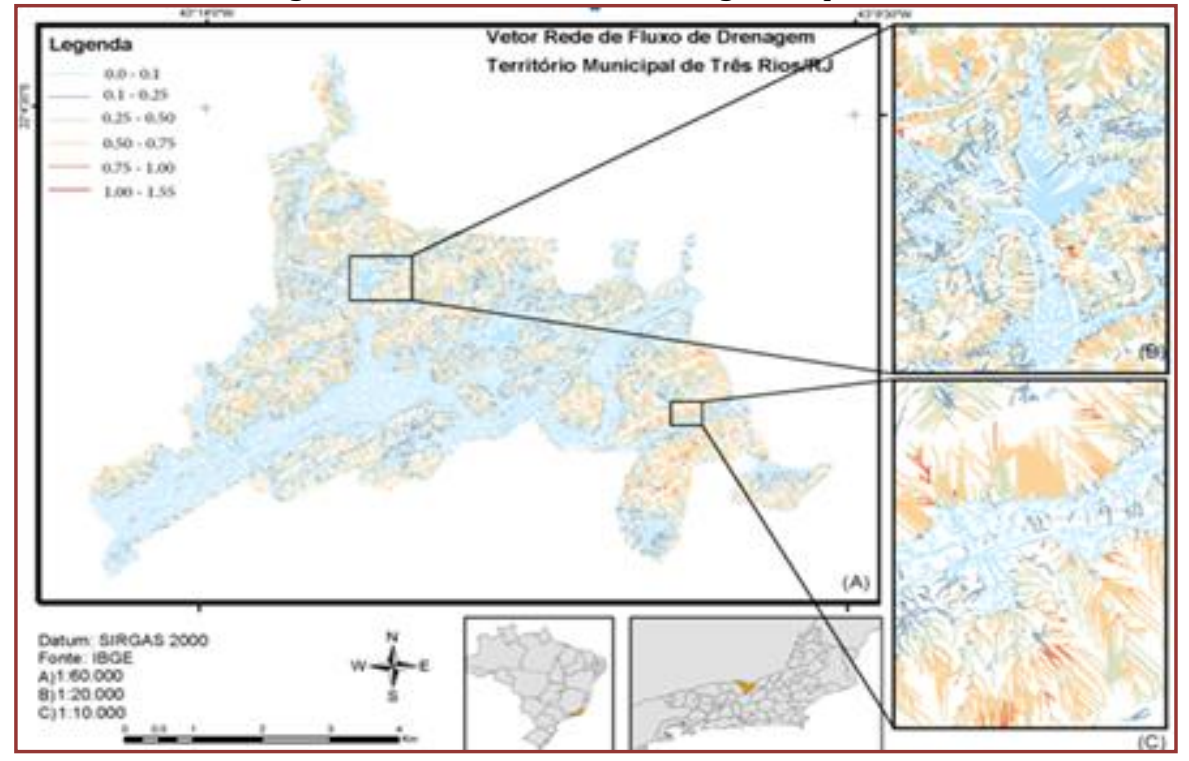


Figura 10 - Grid com os caminhos de direcionamento da rede de drenagem

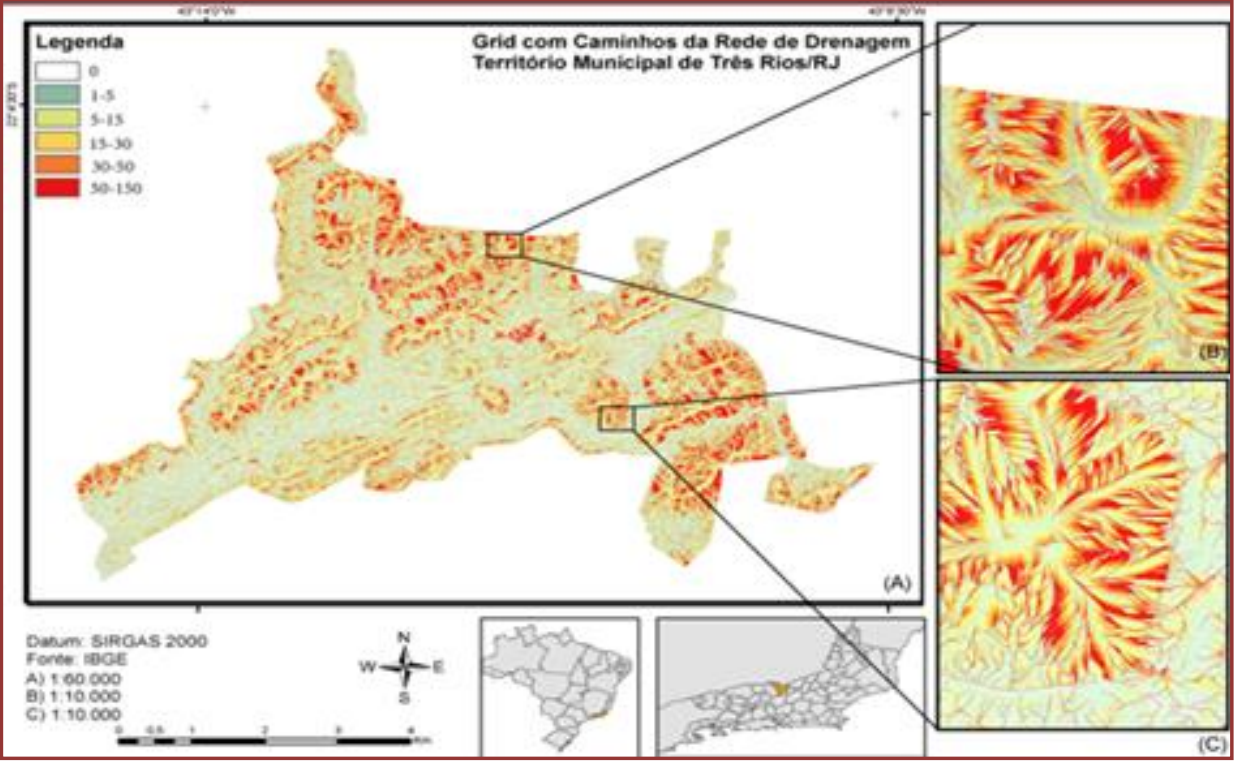

Estes caminhos indicam a distância percorrida pelo fluxo de água e a velocidade que este fluxo chega até a sua base, dado que é obtido a partir da sua inclinação. Com isso, estas informações servem como parâmetro inicial sobre o potencial gerador de risco ocasionado pela ação das águas pluviais em um ambiente urbano. Na na Figura 9, percebe-se os pontos em azul (mais baixos) de concentração das águas pluviais e os caminhos de drenagem individualizados ,enquanto que, na Figura 10, nota-se onde pontos em vermelho como os que concentram as maiores velocidades de escoamento superficial das águas pluviais.

Quando sobreposta a uma imagem de satélite (Figura 11) claramente ficam evidentes os pontos de concentração de água e os caminhos de drenagem pós chuva. Estes caminhos mostram a influência do relevo e da água nas áreas declivosas e potencialmente de risco, e são facimente identificados no grid em vermelho. Uma observação pode ser feita nos pontos mais baixos, onde, a depender da precipitação, pode vir a ter acumulos de água e inundações. Isto, de fato, vem sendo observado nas ultimas chuvas registradas na cidade, sendo um indicativo de uma melhoria da rede de drenagem de águas pluviais. Não obstante, esta figura mostra os caminhos que estas águas percorrem em taludes com grande inclinação, ja indicados na extração do slope do Modelo Digital de Elevação, e antropicamente degradados.

Figura 11 - Sobreposição dos Fluxos e Caminhos que as águas pluviais percorrem, considerando a topografia local em um trecho da zona urbana.

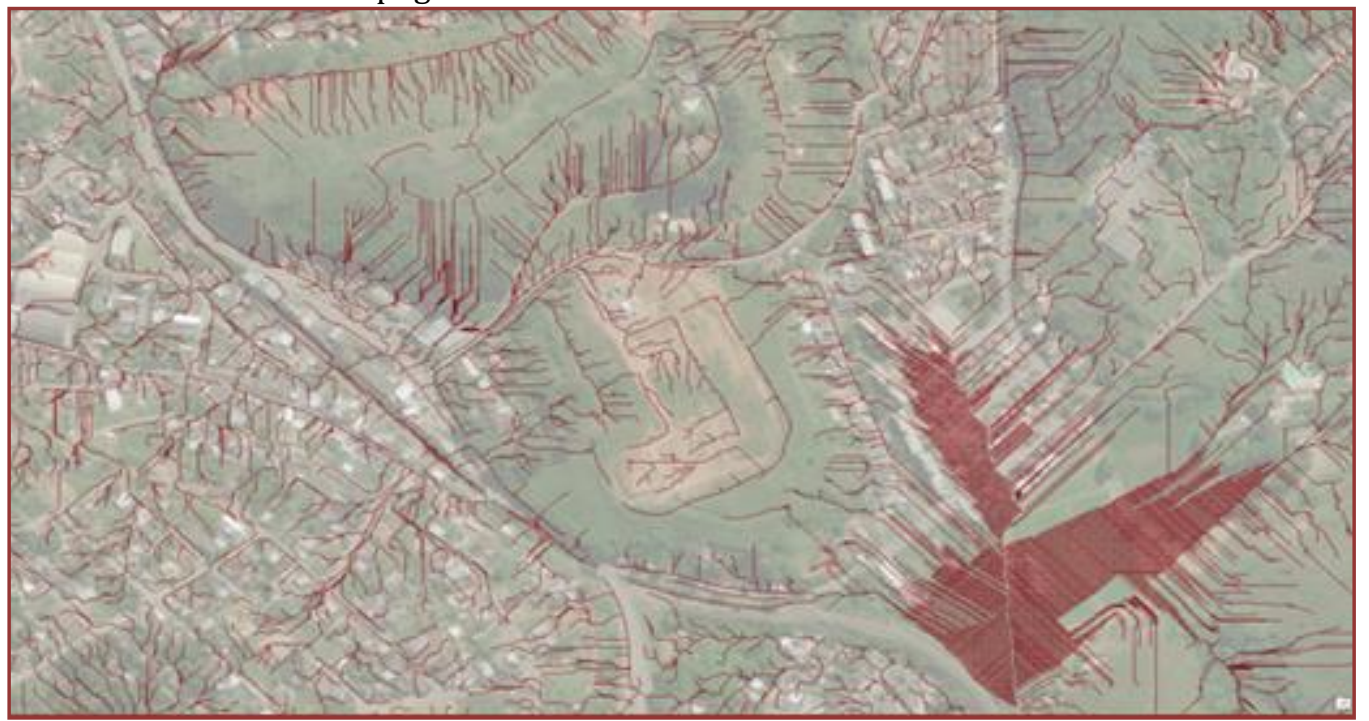


Sabendo-se o caminho de fluxo da drenagem e associando aos parâmetros geotécnicos, estimados a partir dos relatórios de sondagem SPT, pode-se simular o comportamento e espalhamento da água na subsuperfície. Este algoritmo, presente na ferramenta TauDEM, permite entender a distribuição da água na subsuperfície, podendo-se obter um índice de umidade no solo para uma dada condição de precipitação. Esta discussão se faz interessante, principalmente nos taludes com grandes interferências ou dentro das zonas urbanizadas. A Figura 12 é apresentada a área de contribuição específica da subsuperfície, onde fica evidenciado como o se espalha as águas pluviais infiltradas.

Pode-se observer na Figura 12, que os pontos mais escuros são os pontos de início do escoamento subsuperficial lento das águas infiltradas, mostrando o espalhamento célula a célula no solo pelo degrade em escala de cinza. Este cálculo considera o logarítmo da razão entre a distância e a sua inclinação. 0 fluxo de espalhamento termina ate os veios ou caminhos em branco que concentram a água drenada. A importância deste mapa é dada ao simular os locais que venham a ter um aumento ou concentração de água, aumentando o peso dos maciços aumentando o risco de ocorrer uma falha em taludes.

Por fim, foi associado aos parâmetros geotécnicos estimados para os solos da região, como coesão e ângulo de atrito do solo, gerando um mapa ilustrado na Figura 13, que indica as regiões de maior potencial de deslizamento, fornecendo uma informação inicial para que as equipes da defesa civil façam uma verificação in loco quanto a sua fragilidade.

Figura 12 - Espalhamento das Águas pluviais na subsuperfície com estimative do indice de umidade no solo.

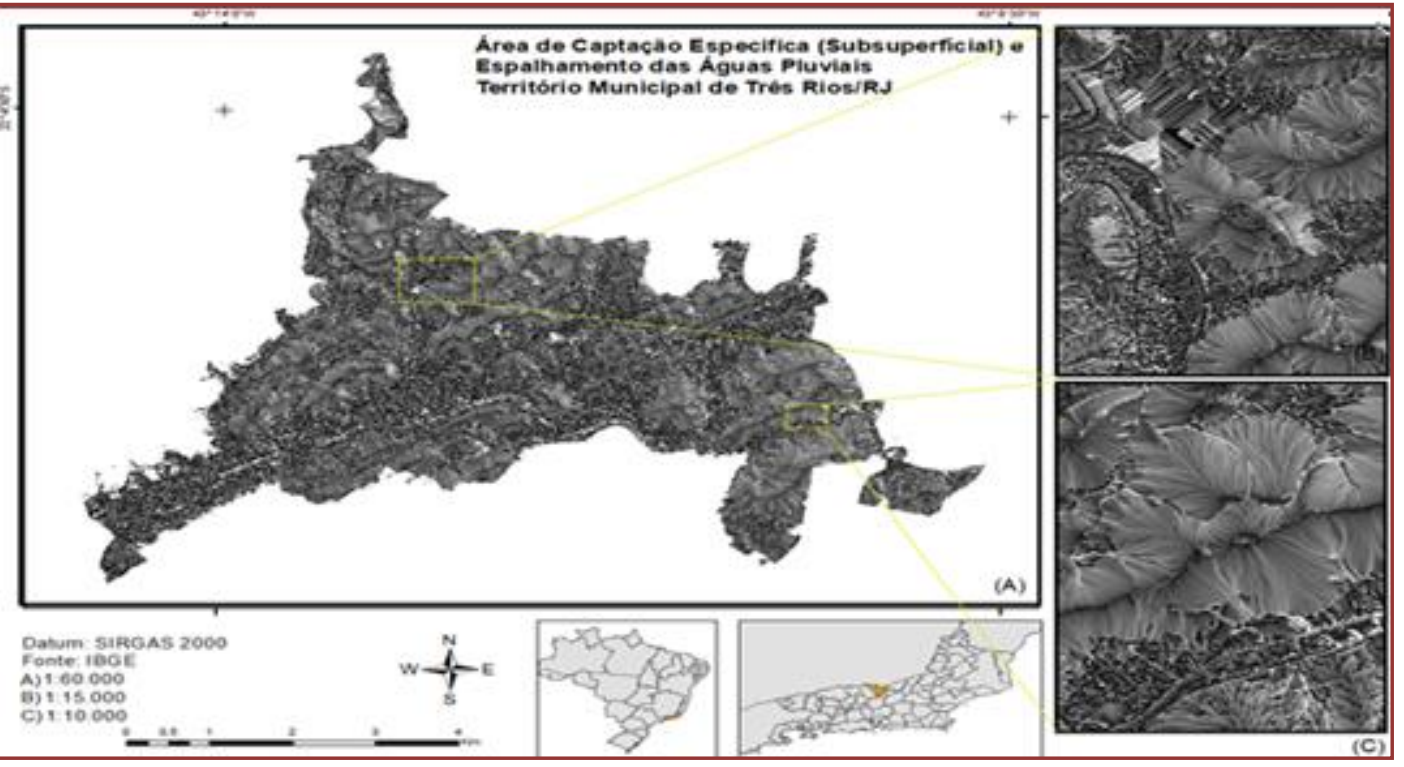


Figura 13 - Áreas vulneráveis, segundo os critérios topográficos, geotécnicos e hidrológicos; (B) Mapa anterior sobreposto a imagem de satélite

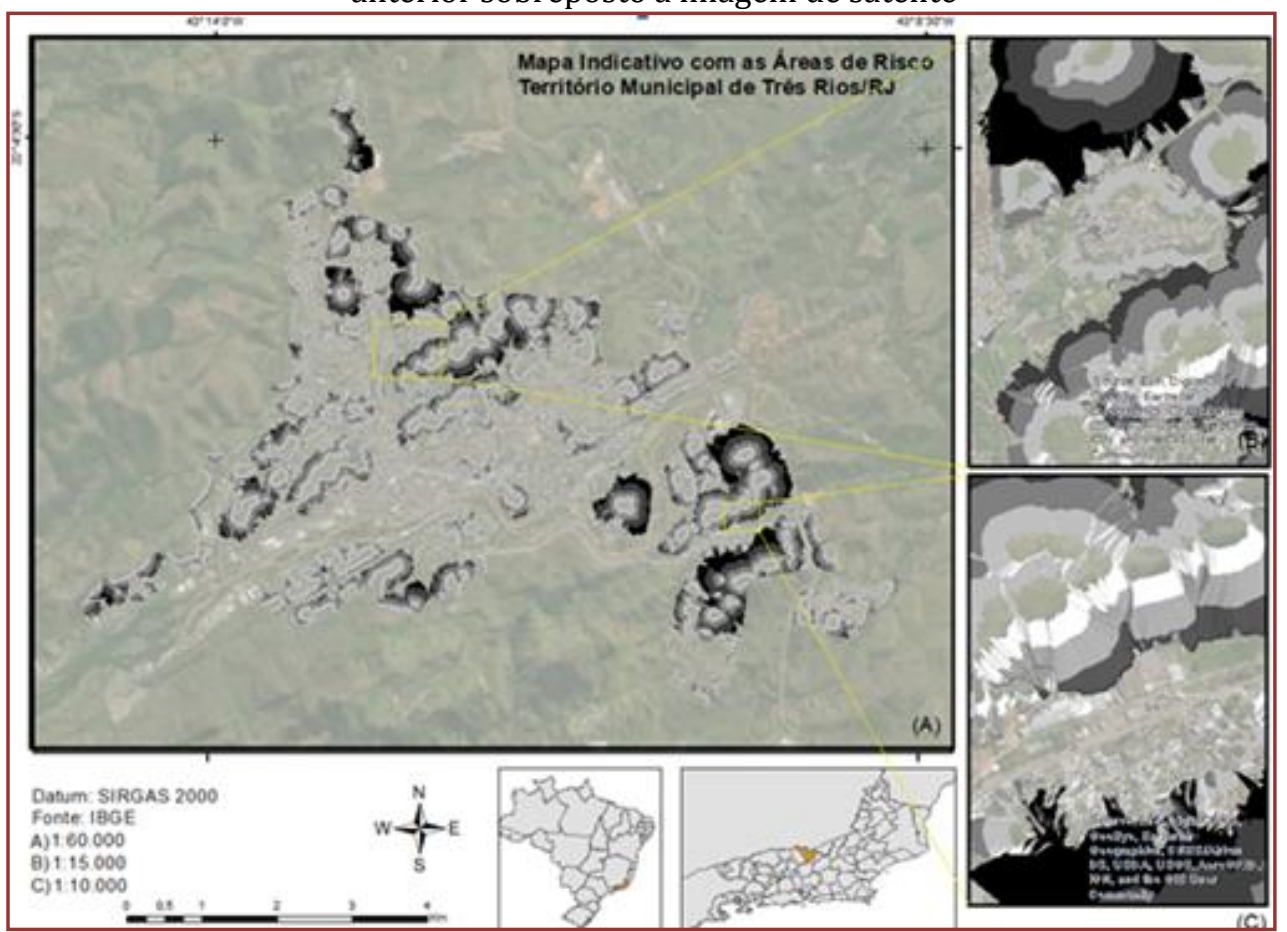

\section{CONCLUSÕES}

A importância de um estudo, com a associação de informações diversas e espacializadas, tendem a aumentar o controle e a precisão dos resultados, condicionando o ambiente para as características de resistência dos materiais e, portanto, a maior e menor possibilidade de ocorrência de movimentos de massa. A dificuldade em se estudar uma quantidade grande de variáveis e as relações entre homemnatureza, criam oportunidade não exploradas de uso do espaço urbano. A forma pelas quais estas variáveis devem ser combinadas, permitem uma série de estudos de potencialidades e riscos, com uso de ferramentas qualitativas de suporte a decisão.

No caso em questão, foi proposto um estudo em escala municipal, que tem a vantagem de indicar todas as áreas com potencial de se tornar uma área de risco com base no relevo, parâmetros geotécnicos e precipitação anual. De posse deste mapa, pode-se sobrepor os padrões de uso do solo e ocupação urbana em ambiente SIG, permitindo uma análise inicial e indicativa para as ações posteriores mais enérgicos.

Os mapas da Figura 11, apresentam os locais na cidade que merecem atenção do poder publico. De posse destes dados, o agente responsável pode verificar in loco as medidas a serem adotadas para a solução de potenciais problemas. 0 maior benefício desta metodologia é a velocidade em fazer uma análise de uma área extensa, a facilidade em integrar outras bases de dados e atualização de informações temporais.

\section{AGRADECIMENTOS}

À CAPES (Coordenadoria de Aperfeiçoamento de Pessoal Nível Superior), Departamento de Engenharia Civil - Geotecnia da Universidade Federal de Viçosa e ao Instituto Três Rios/Universidade Federal Rural do Rio de Janeiro 


\section{REFERÊNCIAS}

[1] Agevap. Plano De Recursos Hídricos Da Bacia Do Rio Paraíba Do Sul. Petrópolis: [S.N.]. Disponível Em: $<$ Http://Www.Comitepiabanha.Org.Br/>.

[2] Cerri, L. E. Da S.; Amaral, C. P. Riscos Geológicos. In: Geologia De Engenharia. 5. Ed. São Paulo: Abge (Associação Brasileira De Geologia De Engenharia), 1998. P. 301-310.

[3] Dietrich, W. E.; Bellugi, D.; Asua, R. R. Validation Of The Shallow Landslide Model, Shalstab, For Forest Management. In: Agu (Org.). . Land Use And Watersheds: Human Influence On Hydrology And Geomorphology In Urban And Forest Areas. 2. Ed. [S.L.]: Wigmosta, Mark S; Burges, Stephen J., 2001. P. 195-227.

[4] Gerscovich, D. M. S. Estabilidade De Taludes - Vol 01campos, Brasiluerj, , 1999.

[5] Inea-Rj. Plano Estadual De Recursos Hídricos Do Estado Do Rio De Janeiro Relatório Síntese. Rio De Janeiro: [S.N.].

[6] Kobiyama, M. Et Al. Prevenção De Desastres Naturais: Conceitos Básicos. Curitiba: Organic Tradings, 2006.

[7] Larrain, P.; Simpson-Housley, P. Percepción Y Prevención De Catástrofes Naturales En Chile. Investigaciones, N. 8, 1994 .

[8] Marache, A. Et Al. Geotechnical Modeling At The City Scale Using Statistical And Geostatistical Tools: The Pessac Case (France). Engineering Geology, V. 107, N. 3-4, P. 67-76, 2009. Disponível Em: $<$ Http://Dx.Doi.Org/10.1016/J.Enggeo.2009.04.003>.

[9] Marcelino, E. V. Desastres Naturais E Geotecnologias - Conceitos Básicos. [S.L.]: Inpe, 2008.

[10] Tarboton, D. G. A New Method For The Determination Of Flow Directions And Upslope Areas In Grid Digital Elevation Models. Water Resources Research, V. 33, N. 2, P. 309-319, 1997. Disponível Em: $<$ Http://Doi.Wiley.Com/10.1029/96wr03137>.

[11] Tarolli, P.; Tarboton, D. G. A New Method For Determination Of Most Likely Landslide Initiation Points And The Evaluation Of Digital Terrain Model Scale In Terrain Stability Mapping. Hydrology And Earth System Sciences, V. 10, N. 5, P. 663-677, 2006

[12] Tominaga, L. K.; Santoro, J.; Amaral, R. Desastres Naturais : Conhecer Para Prevenir. São Paulo: [S.N.].

[13] Un; Isdr, I. S. For D. R. Living With Risk: A Global Review Of Disaster Reduction Initiatives. [S.L.] Un-Isdr, 2004. V. 1 


\section{Capítulo 9}

Análise do plano diretor de Florianópolis quanto a suscetibilidade e risco de desastres naturais

\section{Candido Bordeaux Rego Neto}

\section{Kaliu Teixeira}

Resumo: Este trabalho avalia o zoneamento do Plano Diretor do Município de Florianópolis (Lei Municipal Complementar n 484/2014) em relação aos estudos: Carta de Suscetibilidade a Movimentos Gravitacionais de Massa e Inundações, e, Plano Municipal de Redução de Risco, que foram concluídos após sua aprovação. A análise mostrou que o zoneamento urbano nas áreas de alta suscetibilidade e de riscos altos a muito altos a movimentos gravitacionais de massa foi convergente, e que o mesmo não foi observado para a alta suscetibilidade a alagamentos e inundações, onde há grande variedade de usos possíveis. É apontada a necessidade de elaboração da carta geotécnica de aptidão à urbanização e do Plano Municipal de Macrodrenagem, com a incorporação dos resultados destes estudos nas diretrizes, mapa de zoneamento e exigências de uso e ocupação do solo.

Palavras-Chave: Plano diretor de Florianópolis, Carta de suscetibilidade; Plano Municipal de Redução de Riscos. 


\section{INTRODUÇÃO}

Os trabalhos de elaboração do novo Plano Diretor do Município de Florianópolis se iniciaram em 2006 e no seu desenrolar foi objeto de excessivas discussões comunitárias com muitas polêmicas urbanísticas. Com a mudança no executivo municipal o projeto de lei foi finalizado de forma um tanto abrupta, com manifestação contrária de muitos interessados, e mandado para a apreciação da Câmara de Vereadores, onde após sofrer muitas mudanças, principalmente no mapa de zoneamento, foi aprovada em janeiro de 2014 sob a forma de Lei Complementar $n^{\circ}$ 484/2014. Esta Lei dispõe sobre a Política de Desenvolvimento Urbano, institui o Plano de Uso e Ocupação, os Instrumentos Urbanísticos e o Sistema de Gestão.

A Lei Complementar $n^{\circ} 484 / 2014$ obriga o município a elaborar a carta geotécnica de aptidão à urbanização, estabelecendo diretrizes urbanísticas voltadas para a segurança dos novos parcelamentos do solo, com o mapeamento e classificação das áreas de risco geológico e a atualização do Plano Municipal de Redução de Riscos, de acordo com a Política Nacional de Proteção e Defesa Civil (PNPDEC), estabelecida pela Lei Federal n`12.608/2012; como também impõe a elaboração do Plano Diretor de Macrodrenagem Urbana, estabelecendo o prazo máximo de dois anos para o início destes trabalhos.

\section{PLANO DIRETOR DE FLORIANÓPOLIS}

\subsection{LOCALIZAÇÃO DO MUNICÍPIO}

O Município de Florianópolis situa-se na região Sul do Brasil, sendo capital do Estado de Santa Catarina, possui uma área de $438,5 \mathrm{Km}^{2}$ e se localiza entre os paralelos de 27ำ10' e 27050' de latitude Sul e entre os meridianos de $48^{\circ} 25^{\prime}$ e $48^{\circ} 35^{\prime}$ de longitude Oeste. Os limites geográficos do Município estão configurados em duas porções de terras; uma insular, e outra continental. O Município possui grande diversidade de ecossistemas composto por manguezais, praias, dunas, florestas, encostas, planícies, restingas, lagoas e lagunas. (Figura 1)

Figura 1. Localização.

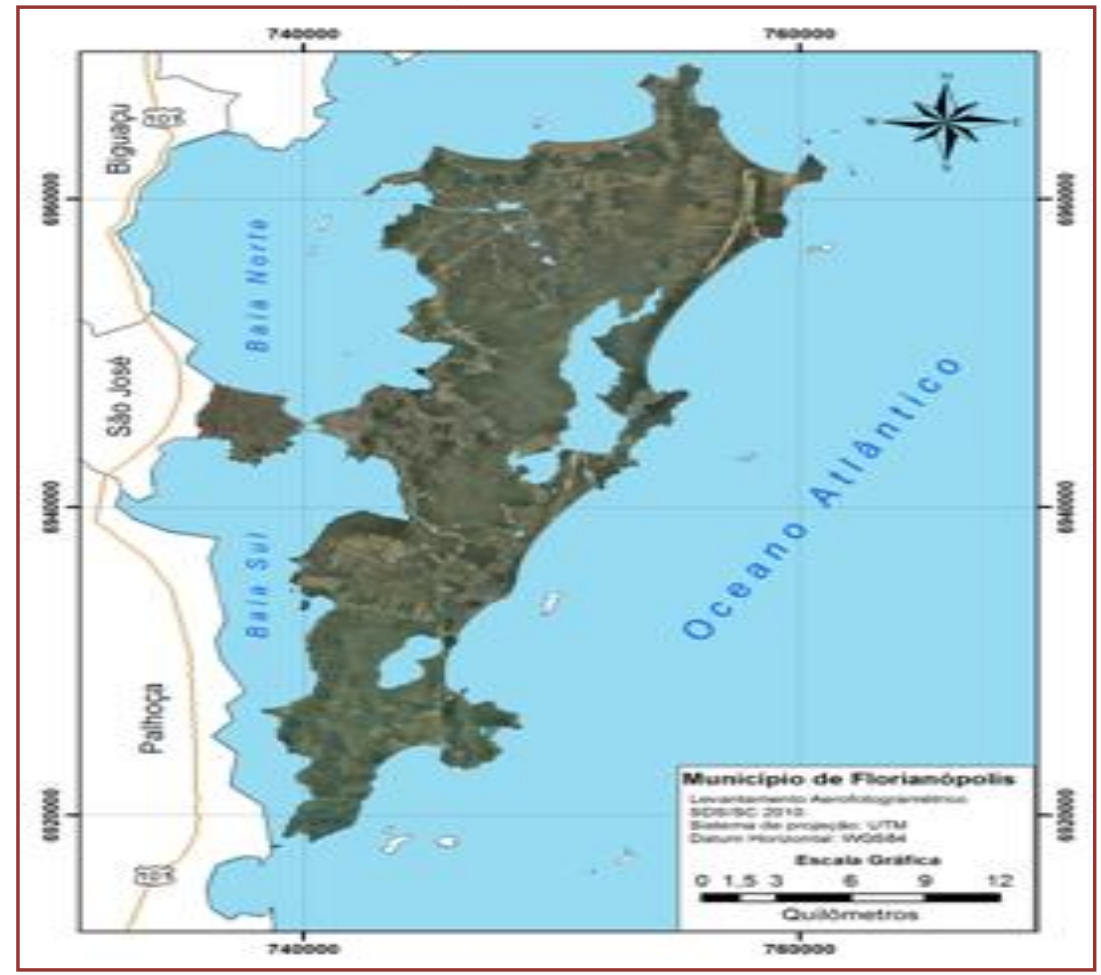




\subsection{MAPA DE ZONEAMENTO URBANO}

Em Florianópolis, o uso e a ocupação do solo são regulados pela Lei Complementar $n^{\circ} 482 / 2014$, que define o zoneamento e os limites de ocupação em todo o Município. Este zoneamento é dividido em zoneamento primário, que define os tipos de usos e a ocupação do solo (Figura 2), e o zoneamento secundário que se sobrepõe ao anterior e determina regras especiais de ocupação.

O Plano Diretor de Florianópolis delimita as áreas protegidas por unidades de conservação e as de uso urbano proibido como Área de Preservação Permanente (APP). As Áreas de Preservação com uso Limitado (APL) de encostas e planícies funcionam como zonas de transição, com o parcelamento do solo proibido e taxa de ocupação máxima de $10 \%$ do imóvel. A Área Residencial Rural (ARR) e a Área de Urbanização Especial (AUE) também têm o objetivo de criar espaços intermediários entre o urbano e o não urbano.

Figura 2. Mapa de zoneamento do Plano Diretor de Florianópolis.

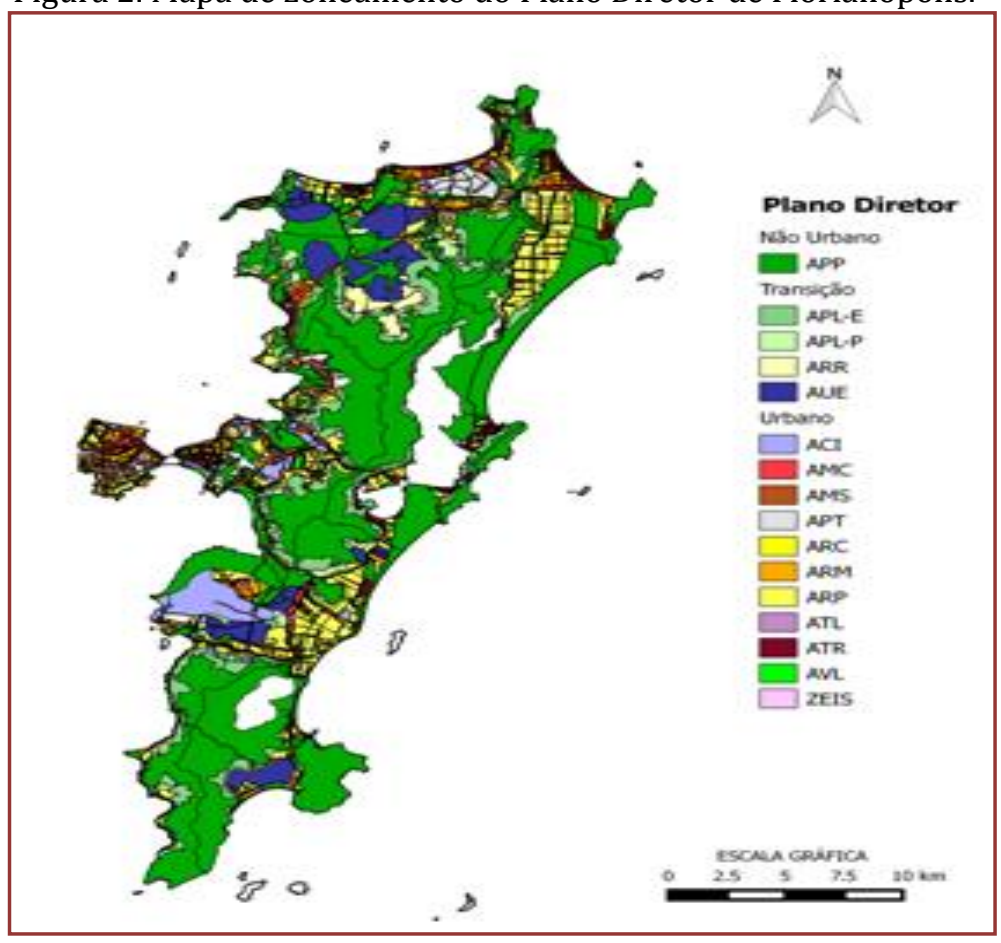

O zoneamento de usos urbanos segue uma diretriz não explícita de graduação de complexidade a partir da Área Mista Central (AMC), passando por Área Residencial Mista (ARM) a Área Residencial Predominante (ARP). As Áreas Residenciais Culturais (ARC) são assentamentos culturais peculiares; e, a Zona de Especial Interesse Social (ZEIS) de assentamentos precários que necessitam de intervenção urbana. Ao longo da costa se encontram a Área Turística Residencial (ATR) e a Área Turística de Lazer (ATL); e, em trechos dos principais corredores do sistema viário as Áreas Mistas de Serviços (AMS). As Áreas Verdes de Lazer (AVL) e as Áreas Comunitárias Institucionais (ACI) estão dispersas segundo as características dos equipamentos que as contém. O Plano Diretor não prevê zonas industriais no Município, exceto indústrias tecnológicas não poluentes mapeadas como Área de Parque Tecnológico (APT).

Além do zoneamento primário do Plano Diretor, que define o uso e a ocupação do solo, existe muitas vezes sobreposto a este um zoneamento secundário, que acrescentam incentivos ou limitações especiais, dentre estes se destacam as Áreas de Especial Interesse Social (AEIS); as Áreas de Preservação Cultural (APC); as Áreas de Risco Geológico (ARG); e, as Áreas de Limitação Ambiental (ALA): de vegetação protegida (ALA1), de banhado (ALA-2) e tombada por Decreto Municipal (ALA-3).

A diferença entre a área total do Município $\left(438,5 \mathrm{Km}^{2}\right)$ e o zoneamento total do Plano Diretor de Florianópolis $\left(388,1 \mathrm{Km}^{2}\right)$, mostrado na Tabela 1, é devido a soma dos espelhos d'água (lagoas e lagunas) e do sistema viário principal. Observa-se que cerca de $50 \%$ do zoneamento correspondem as áreas de APP e $20 \%$ as áreas de transição (APL, ARR e AUE), restando os outros 30\% como área urbanizável. 
Tabela 1. Zoneamento do Plano Diretor de Florianópolis.

\begin{tabular}{|l|c|}
\multicolumn{1}{|c}{ ZONEAMENTO ÁREA $\left(\mathrm{KM}^{2}\right)$} \\
\hline ACI - Área Comunitária Institucional & 16,32 \\
\hline AMC - Área Mista Central & 9,62 \\
\hline AMS - Área Mista de Serviços & 5,94 \\
\hline APL-E - Área de Preservação Uso Limitado (Encosta) & 41,74 \\
\hline APL-P - Área de Preservação Uso Limitado (Planície) & 6,03 \\
\hline APP - Área de Preservação Permanente & 194,30 \\
\hline APT - Área de Parque Tecnológico & 3,89 \\
\hline ARC - Área Residencial Cultural & 0,09 \\
\hline ARM - Área Residencial Mista & 18,19 \\
\hline ARP - Área Residencial Predominante & 48,08 \\
\hline ARR - Área Residencial Rural & 6,56 \\
\hline ATL - Área Turística de Lazer & 0,15 \\
\hline ATR - Área Turística Residencial & 5,35 \\
\hline AUE - Área de Urbanização Especial & 22,57 \\
\hline AVL - Área Verde de Lazer & 5,00 \\
\hline ZEIS - Zona Especial de Interesse Social & 4,27 \\
\hline \multicolumn{1}{|c|}{ TOTAL } & $388,10 \mathrm{KM}^{2}$ \\
\hline
\end{tabular}

\section{ESTUDOS DE SUSCETIBILIDADE A DESASTRES NATURAIS E ÁREAS DE RISCO EM FLORIANÓPOLIS}

\subsection{CARTA DE SUSCETIBILIDADE A MOVIMENTOS GRAVITACIONAIS DE MASSA E INUNDAÇÕES}

A carta de suscetibilidade a movimentos gravitacionais de massa e inundações foi elaborada para o município de Florianópolis por IPT/CPRM (2014), sob a coordenação do Serviço Geológico do Brasil (CPRM), em atenção às diretrizes da Política Nacional de Proteção e Defesa Civil (PNPDEC), estabelecida pela Lei Federal 12.608/2012, para ser utilizada em atividades de planejamento e gestão territorial e de prevenção de desastres naturais, apontando as áreas mais suscetíveis em relação aos processos do meio físico analisados.

Os processos do meio físico analisados compreenderam os principais tipos de movimentos gravitacionais de massa (deslizamentos; rastejos; quedas, tombamentos, desplacamentos e rolamentos de rochas; e corridas de massa) e de processos hidrológicos (inundações e enxurradas), os quais estão frequentemente associados aos desastres naturais ocorridos no Brasil.

A suscetibilidade, definida como a propensão ao desenvolvimento de um fenômeno ou processo em uma dada área foi mapeada (IPT/CPRM, 2014a) como: alta, média ou baixa, apontando áreas onde a propensão é maior ou menor em comparação a outras.

A figura 3 mostra as áreas definidas como de suscetibilidade alta a movimentos gravitacionais e inundações. A incidência de alta suscetibilidade em áreas urbanizadas pressupõe condições com potencial de risco maior e requer estudos específicos. 
Figura 3. Alta Suscetibilidade a Movimentos Gravitacionais de Massa e Inundações. Modificado de IPT (2014a).

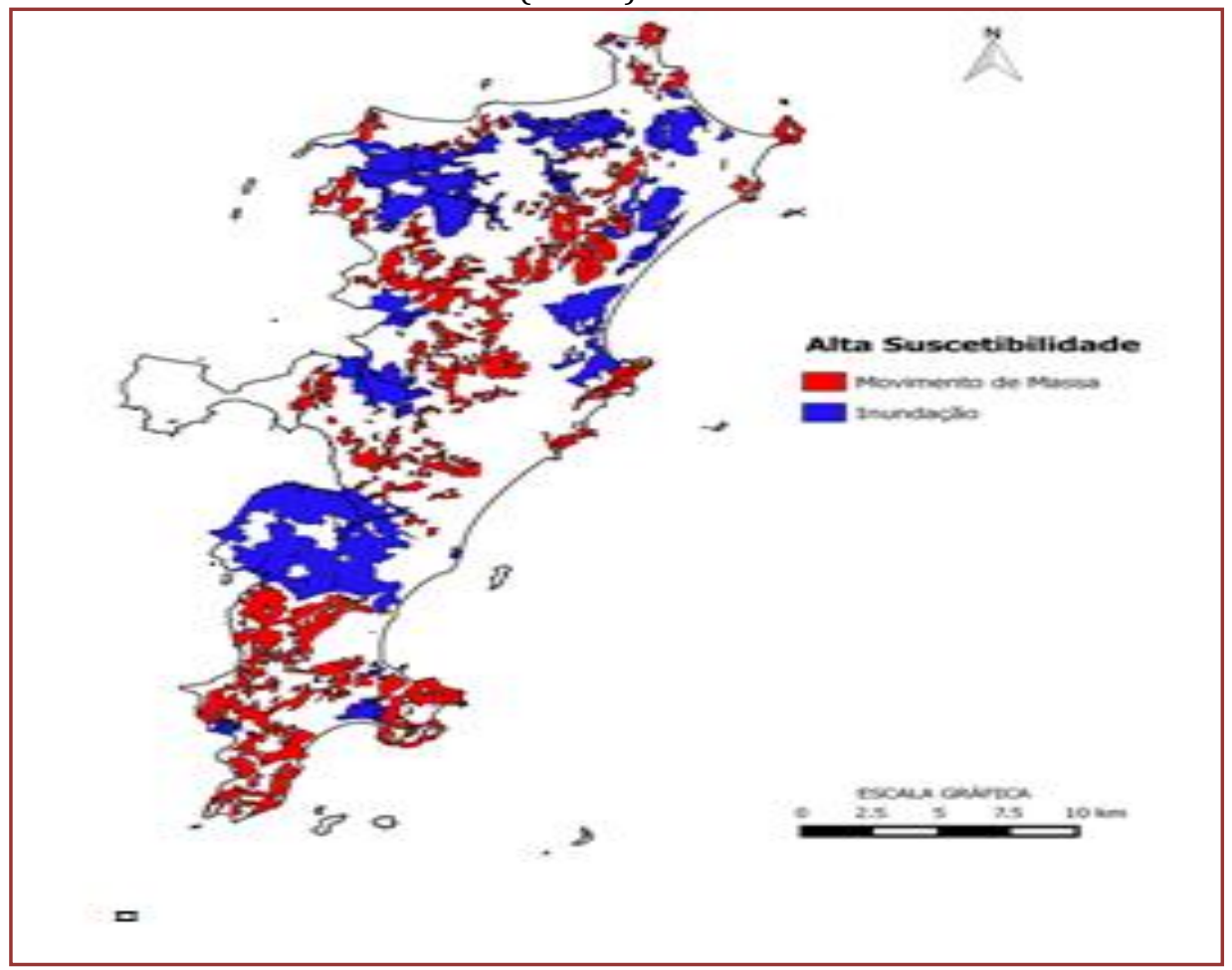

\subsection{PLANO MUNICIPAL DE REDUÇÃO DE RISCOS}

A FUNDAÇÃO ISRAEL PINHEIRO (2014) foi contratada pela Prefeitura Municipal de Florianópolis para realizar a revisão do diagnóstico de risco geológico nas áreas de ocupação irregular do município, já mapeados em 2007, com a definição dos setores de risco geológico alto e muito alto e quantificação das moradias expostas a esses níveis de risco, bem como a análise de novas áreas apontadas pela administração pública que ainda não tinham sido alvo de mapeamento.

0 trabalho está em consonância com a Lei 12.608/12 que estabeleceu o dever da União, dos Estados, do Distrito Federal e dos Municípios adotarem as medidas necessárias para a redução dos riscos de desastre natural.

No município de Florianópolis o Plano Municipal de Redução de Risco - PMRR contemplou 41 áreas com o mapeamento e diagnóstico das seguintes tipologias de risco geológico: Deslizamento de solo e rocha, processos erosivos, recalques e abatimentos, avanço de dunas, solapamentos de margens de córregos e delimitação de processos de alagamento e inundação.

As 41 áreas definidas pela Prefeitura Municipal de Florianópolis foram delimitadas em setores e classificadas segundo o seguinte grau de probabilidade de riscos: Baixo (R1) - É a condição menos crítica; Médio (R2) - Processo de instabilização em estágio inicial de desenvolvimento; Alto (R3) - Processo de instabilização em pleno desenvolvimento, ainda sendo possível monitorar a evolução do processo; e, Muito Alto (R4) - É a condição mais crítica, sendo impossível monitorar a evolução do processo, dado seu elevado estágio de desenvolvimento.

Todas as 41 áreas serão incluídas na revisão do Plano Diretor de Florianópolis como zoneamento secundário ARG, e já estão disponibilizadas no Geoprocessamento Corporativo do Município para serem consideradas nas Consultas de Viabilidade para construções.

Na Figura 4 são mostradas as 36 áreas caracterizadas como movimento gravitacional de massa, onde foram observados processos geodinâmicos como: deslizamento, queda e rolamento de blocos. Os outros tipos de risco geológico (inundação, movimentação de dunas e erosão costeira) foram excluídos pelo pequeno número de áreas levantadas no PMRR. 
Figura 4. Áreas de Risco a Movimentos Gravitacionais de Massa. Modificado de Fundação Israel Pinheiro (2014).

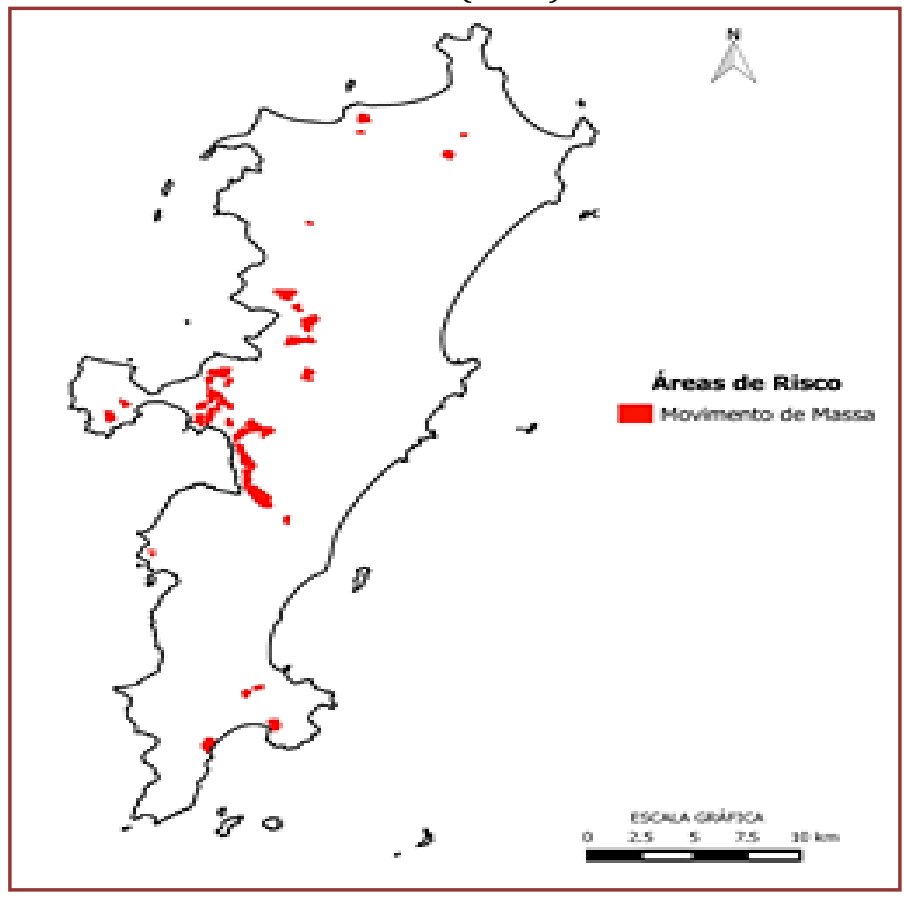

\section{VERIFICAÇÃO DA SUSTENTABILIDADE A DESASTRES NATURAIS DO PLANO DIRETOR DE FLORIANÓPOLIS}

\subsection{TABULAÇÃO DOS DADOS}

No cruzamento de mapas e dados para análise do Plano Diretor de Florianópolis utilizou-se a metodologia do Sistema de Informações Geográficas - SIG.

Após o tratamento das variáveis, colocadas em sistema de coordenada único foi utilizada a ferramenta INTERCECTION, onde os dados de entrada foram os arquivos referentes ao zoneamento do Plano Diretor de Florianópolis e as variáveis: Alta Suscetibilidade a Movimento de Massa e Inundação (modificado de IPT/CPRM, 2014a); e, Áreas de Riscos a Movimento de Massa (modificado de Fundação Israel Pinheiro, 2014), gerando novos arquivos compostos pelas áreas sobrepostas. Os arquivos resultantes foram classificados e através da ferramenta SUMMARY STATISTICS, se obteve a soma total da área de zoneamento para cada variável. Com os valores das áreas foi utilizada a ferramenta CALCULAT FIELD, para se obter o percentual da área de cada zoneamento colocados nas tabelas 2 e 3.

As áreas em $\mathrm{Km}^{2}$ de altas suscetibilidades a inundações e de movimentos gravitacionais de massa são equivalentes, como mostra a Tabela 2 , e atingem cerca de $40 \%$ da área zoneada no plano diretor de urbanização de Florianópolis.

Os zoneamentos com as maiores áreas consideradas como alta suscetibilidade a inundação são respectivamente APP, ARP, AUE, ACI e ARM, somando quase $80 \%$ do total. As áreas zoneadas no Plano Diretor de Florianópolis que tiveram maior percentual considerado de alta suscetibilidade a inundações em ordem decrescente foram as APT, APL-P, AUE e ACI.

Os zoneamentos APP e APL-E abrangem mais de $97 \%$ da área total considerada como de alta suscetibilidade a movimentos gravitacionais de massa. As áreas zoneadas no plano diretor de Florianópolis, que foram mapeadas com percentual maior que 3\% como alta suscetibilidade a movimentos gravitacionais de massa foram as APP, APL-E e ZEIS. 
Tópicos em Geologia - Volume 1

Tabela 2. Altas suscetibilidades a inundações e movimentos de massa do Plano Diretor de Florianópolis.

\begin{tabular}{|c|c|c|c|c|}
\hline \multirow{3}{*}{ Zoneamento } & \multicolumn{4}{|c|}{ ALTA SUSCETIBILIDADE } \\
\hline & \multicolumn{2}{|c|}{ Inundações } & \multicolumn{2}{|c|}{ Movimentos Gravitacionais de Massa } \\
\hline & $\left(\mathbf{K M}^{2}\right)$ & $(\%)$ & $\left(\mathbf{K M}^{2}\right)$ & $(\%)$ \\
\hline ACI & 6,84 & 41,91 & 0,05 & 0,32 \\
\hline AMC & 2,53 & 26,29 & 0,01 & 0,11 \\
\hline AMS & 1,91 & 32,15 & 0,07 & 1,21 \\
\hline APL-E & 2,15 & 5,15 & 7,43 & 17,79 \\
\hline APL-P & 3,35 & 55,55 & 0,01 & 0,24 \\
\hline APP & 26,92 & 13,85 & 65,86 & 33,90 \\
\hline APT & 2,57 & 66,06 & 0,18 & 1,00 \\
\hline ARM & 4,61 & 25,34 & 0,79 & 1,65 \\
\hline ARP & 12,4 & 25,79 & 0,02 & 0,33 \\
\hline ARR & 1,04 & 2,16 & 0,00 & 3,02 \\
\hline ATR & 0,58 & 10,84 & 0,01 & 0,17 \\
\hline AUE & 9,77 & 43,28 & 0,13 & 0,56 \\
\hline AVL & 0,85 & 17,00 & 0,08 & 1,57 \\
\hline ZEIS & 0,65 & 15,22 & 0,84 & 19,57 \\
\hline TOTAL & $76,17 \mathrm{KM}^{2}$ & $19,63 \%$ & $75,48 \mathrm{KM}^{2}$ & $19,45 \%$ \\
\hline
\end{tabular}

OBS: As altas suscetibilidades a inundação e movimento de massa não se apresentam em ARC e ATL.

Os objetivos iniciais do PMRR elaborado pela Fundação Israel Pinheiro foram revisar e atualizar o mapeamento de riscos de deslizamento em encostas, com posterior inclusão de algumas áreas com outros riscos geológicos (inundações, movimentação de dunas e erosão marinha).

As áreas de risco a inundações não foram levantadas com abrangência suficiente para sua comparação com a carta de alta suscetibilidade a inundações. As inundações e alagamentos em Florianópolis são de pequena intensidade e duração, devido às peculiaridades de ser constituída como ilha costeira em sua grande porção, dividida em direção predominante Norte-Sul por encostas, formando pequenas bacias hidrográficas que deságuam em manguezais, baías ou diretamente no oceano. As inundações não foram priorizadas no PMRR, apesar dos grandes prejuízos materiais e financeiros que acarretam.

A coluna Risco 1, 2, 3 e 4, mostrada na Tabela 3, representa a área total definida para o estudo de risco a movimentos gravitacionais de massa no PMRR, que abrangeu cerca de $12 \mathrm{Km}^{2}$. As áreas consideradas de risco alto (Risco 3) somaram cerca de $0,6 \mathrm{Km}^{2}$ e as áreas de risco muito alto (Risco 4) pouco mais de $18.000 \mathrm{~m}^{2}$. Os zoneamentos APP, APL-E e ZEIS foram os mais significativos para os Riscos 3 e 4

Tabela 3. Grau de risco a movimentos de massa do Plano Diretor de Florianópolis.

\begin{tabular}{|c|c|c|c|c|c|c|}
\hline \multirow{3}{*}{ Zoneamento } & \multicolumn{6}{|c|}{ RISCO A MOVIMENTOS DE MASSA } \\
\hline & \multicolumn{2}{|c|}{ Risco 1, 2, 3 e 4} & \multicolumn{2}{|c|}{ Risco 3} & \multicolumn{2}{|c|}{ Risco 4} \\
\hline & $\left(\mathrm{Km}^{2}\right)$ & $(\%)$ & $\left(\mathrm{M}^{2}\right)$ & $(\%)$ & $\left(\mathrm{M}^{2}\right)$ & $(\%)$ \\
\hline ACI & 0,12 & 0,76 & 2.389 & 0,01 & 249 & 0,001 \\
\hline AMC & 0,25 & 2,58 & 3.152 & 0,03 & 370 & 0,004 \\
\hline AMS & 0,34 & 5,68 & 16.458 & 0,28 & - & - \\
\hline APL-E & 2,71 & 6,49 & 112.332 & 0,27 & 12.863 & 0,031 \\
\hline APL-P & 0,11 & 1,76 & - & - & - & - \\
\hline APP & 2,49 & 1,28 & 176.526 & 0,09 & 629 & 0,000 \\
\hline ARM & 0,86 & 4,75 & 22.561 & 0,12 & 205 & 0,001 \\
\hline ARP & 2,40 & 5,00 & 60.209 & 0,13 & - & - \\
\hline ARR & 0,14 & 2,21 & - & - & - & - \\
\hline AVL & 0,12 & 0,01 & 2.659 & 3,40 & - & - \\
\hline ZEIS & 2,45 & 2,39 & 247.296 & 5,79 & 4.217 & 0,099 \\
\hline TOTAL & $11,99 \mathrm{Km}^{2}$ & $3,09 \%$ & $0,64 \mathrm{Km}^{2}$ & $0,17 \%$ & $0,02 \mathrm{Km}^{2}$ & $0,005 \%$ \\
\hline
\end{tabular}

OBS: O risco a movimentos de massa não se apresentam em APT, ARC, ATL, ATR e AUE. 


\subsection{DISCUSSÃO DOS RESULTADOS}

Os estudos realizados para movimentos gravitacionais de massa na Carta de Suscetibilidade e no PMRR, mostraram que o Plano Diretor de Florianópolis zoneou preponderantemente as áreas de altas suscetibilidades e as de altos riscos a este tipo de desastres naturais como: APP, APL-E e ZEIS. As áreas zoneadas como ZEIS nestes casos são as encostas com características de APP e APL-E, que sofreram ocupação desordenada por populações de baixa renda. Os 3,4\% de AVL com Risco 3 devem ser creditados a loteamentos que tiveram áreas com características de APP e/ou APL-E aprovados como AVL.

Conforme descrito por REGO NETO (2008) foi mantido como APP no novo Plano Diretor de Florianópolis as declividades acima de $46,6 \%$ ou $25^{\circ}$, seguindo os critérios dos antigos planos diretores de Florianópolis, e mais restritiva que o novo Código Florestal (Lei № 12.651/2012) que estipula 100\% $\left(45^{\circ}\right)$. As APP dos topos de morros e linhas de cumeadas seguiram o estipulado pelo Art. $3^{\circ}$ da Resolução CONAMA 303/2002, também bastante mais restritiva que a legislação federal.

As declividades entre $30 \%$ e $46,6 \%\left(17^{\circ}\right.$ e $\left.25^{\circ}\right)$ foram consideradas no Plano Diretor de Florianópolis como APL-E, onde o zoneamento não permite o parcelamento do solo e a taxa de ocupação máxima é de $10 \%$.

SANTOS (2012) afirma baseado em estudos realizados para a Serra do Mar no Estado de São Paulo que as declividades das encostas começam a se mostrar mais susceptíveis a escorregamentos a partir de inclinações em torno de $30^{\circ}$ e $35^{\circ}$ e quanto à forma, os trechos retilíneos, especialmente os do terço superior dos espigões ou morros isolados, mostram-se nitidamente mais instáveis.

O Plano Diretor de Florianópolis preserva, portanto as inclinações acima de $25^{\circ}$ e o terço superior dos morros como APP, além de impor fortes restrições a partir das inclinações de $17^{\circ}$.

O mapa de alta suscetibilidade a inundações (IPT/CPRM, 2014a) representou no Plano Diretor de Florianópolis uma maior diversidade de zoneamento, sobressaindo em área total as APP, ARP, AUE, ACI e ARM; e em porcentagem do zoneamento: APT, APL-P, AUE e ACI.

A cartografia base do plano diretor de Florianópolis tem algumas deficiências, como a falta de classificação dos cursos d'água natural perene e intermitente, que impediram a delimitação de suas faixas marginais de proteção no mapa do zoneamento. Apesar de não aparecer no zoneamento, estas faixas são consideradas APP no texto da Lei Complementar $n^{\circ} 484 / 2014$, devendo ser consideradas zoneadas como tal nas Consultas de Viabilidade para construções, além de ser previsto na Lei a realização obrigatória do levantamento e classificação dos cursos d'água, com prazo de um ano para sua conclusão, e futura inclusão na revisão do mapa de zoneamento.

A ausência da faixa de APP dos cursos d'água naturais, ajuda a explicar a variedade de zoneamentos urbanos em áreas de alta suscetibilidades a inundações, mas a atratividade de ocupação das baixadas na Ilha de Santa Catarina é o fator preponderante.

Conforme REGO NETO (2013) o Plano Diretor de Florianópolis incluiu no seu zoneamento secundário áreas com limitações ambientais, definidas como locais de ocorrência natural, cuja característica ambiental representa alguma limitação à ocupação urbana, estabelecendo entre outras as áreas inundáveis definidas como banhado (ALA-2). Estas limitações ambientais devem ser observadas nas Consultas de Viabilidade para construções.

As áreas zoneadas como APT, APL-P e AUE já prevêem algumas medidas para evitar ou minimizar o problema de inundações e alagamentos, e a Lei Complementar $n^{\circ} 484 / 2014$ obriga o município a iniciar no prazo máximo de dois anos o Plano Municipal de Macrodrenagem, que é de fundamental importância para o aprimoramento desta Lei.

O Plano Municipal de Macrodrenagem deverá indicar o melhor zoneamento urbano e onde deve ser evitada a ocupação. As regiões com alta suscetibilidade a inundações não devem ser passíveis de grandes aglomerados urbanos, necessitando serem previstos espaços para servirem como barreira de contenção ou redução do pico das cheias como parques, praças, lagos e outros espaços verdes ou de lazer.

\section{CONCLUSÕES}

A Carta de Suscetibilidade a Movimentos Gravitacionais de Massa e Inundações, e a atualização do Plano Municipal de Redução de Riscos, serviram de base para a avaliação do zoneamento urbano do Plano Diretor de Florianópolis quanto a estas suscetibilidades e riscos de desastres naturais. 
Os resultados mostram que os critérios utilizados no zoneamento das encostas do município de Florianópolis para a delimitação de áreas de preservação (APP), de restrições na ocupação (APL-E), e com necessidade de intervenções urbanas (ZEIS), coincidiram preponderantemente com as áreas definidas nos estudos como de altas suscetibilidades e de riscos altos a desastres naturais.

As vantagens paisagísticas e ambientais das restrições impostas, baseadas em inclinações das encostas e nas porções superiores dos morros, não eliminam a necessidade de estudos geológico-geotécnicos para a prevenção de riscos geológicos, e na indicação de formas mais seguras para o uso do solo no Município.

Quanto a alagamentos e inundações, apesar da previsão destas ocorrências no texto e no mapa de zoneamento secundário da Lei Complementar $n^{\circ} 484 / 2014$, os resultados desta preocupação não foram diretamente observados no zoneamento urbano.

Para o aprimoramento do zoneamento urbano é imprescindível a elaboração da carta geotécnica de aptidão à urbanização, além da confecção do Plano Municipal de Macrodrenagem, já previstos em Lei, como também o seu efetivo rebatimento nas diretrizes, no mapa e exigências de uso e ocupação do solo do Plano Diretor de Florianópolis.

\section{REFERÊNCIAS}

[1] Fundação Israel Pinheiro (2014). Revisão do Plano Municipal de Redução de Risco - PMRR - Florianópolis SC. Coordenação Geral: Leonardo Andrade de Souza: 7a Etapa. Contendo a versão final do Plano Municipal de Redução de Risco do Município de Florianópolis (ㅁocumento Inédito). Florianópolis. Novembro de 2014. 763p.

[2] Ipt / Cprm (2014). Cartas de suscetibilidade a movimentos gravitacionais de massa e inundações: nota técnica explicativa / coordenação Omar Yazbek Bitar. -- São Paulo: IPT - Instituto de Pesquisas Tecnológicas do Estado de São Paulo; Brasília, DF: CPRM - Serviço Geológico do Brasil, 2014. (Publicação IPT; 3016). ISBN 978-85-09-00177$3,42 \mathrm{p}$.

[3] Ipt / Cprm (2014a). MAPA: Carta de suscetibilidade a movimentos gravitacionais de massa e inundações: Município de Florianópolis. Escala 1:50.000. Carta Síntese - Versão 02 / Coordenação Omar Yazbek Bitar. IPT Instituto de Pesquisas Tecnológicas do Estado de São Paulo \& CPRM - Serviço Geológico do Brasil. Março de 2014

[4] Rego Neto, C. B. \& Lima JR, C. (2008). "Zoneamento geoambiental para fundamentar o plano diretor participativo de Florianópolis" in Anais do $12^{\circ}$ Congresso Brasileiro de Geologia de Engenharia e Ambiental, Porto de Galinhas, Nov. 2008. 1, pp. 1-11.

[5] Rego Neto, C. B. (2013). "A Inserção da Geologia de Engenharia e Ambiental na Lei do Plano Diretor de Urbanização - Exemplo de Florianópolis" in Sessão Técnica do 8o SBCGG. Anais do 14o Congresso Brasileiro de Geologia de Engenharia e Ambiental, Porto de Galinhas, Rio de Janeiro, Dez. 2013. PAP014045

[6] Santos, A. R. dos. Enchentes e deslizamentos: causas e soluções: áreas de risco no Brasil. São Paulo: Pini, 2012. ISBN 978-85-7266-262-8,136p. 


\section{Capítulo 10}

\section{Estudo do mecanismo de rockburst na Serra do Mar}

\section{João Pedro Silva Pereira \\ Wilson Shoji Iyomasa \\ Edilson Pizzato}

Resumo: Expondo rochas ígneas e metamórficas de idade pré-cambriana e tendo passado por muitos processos geológicos ao longo do tempo, a Serra do Mar configurase como uma das mais complexas feições geomorfológicas do território brasileiro. A expressiva heterogeneidade na estrutura dos maciços geológicos que a compõe caracteriza estado de tensões in situ extremamente variado ao longo de toda sua extensão, podendo gerar facilmente concentrações de tensões próximas às superfícies de escavações subterrâneas realizadas. Neste contexto a compreensão de como ocorre a concentração de altas tensões em consequência de aspectos como estrutura geológica do maciço, parâmetros físicos da rocha, tensão tectônica residual etc. e sua relação com o acúmulo de energia elástica necessária ao desenvolvimento de rockburst, é algo essencial para se prevenir de eventuais imprevistos denominados geológicos. Para tal utiliza-se neste projeto de iniciação tecnológica, ainda em andamento, o levantamento bibliográfico e a modelagem numérica por meio do software RS2 (v 9.0) da Rocscience, para tentar compreender melhor e buscar formas de evitar eventos do tipo rockburst no processo de ocupação do subsolo brasileiro. Em etapa posterior da pesquisa pretende-se identificar medidas preventivas para reduzir a intensidade desse fenômeno, como alterar (se possível) as direções das escavações, ou até mesmo procedimentos de projetos de engenharia para contenção desta modalidade de desplacamento de rocha. 


\section{INTRODUÇÃO}

A Serra do Mar é uma característica ímpar no Sudeste brasileiro. Outrora descrita por historiadores como feição geomorfológica de difícil transposição em virtude dos relatos sobre as exaustivas viagens realizadas por índios, jesuítas e bandeirantes com o objetivo de estabelecer a conexão entre o litoral e o interior do país, a Serra do Mar ocupa hoje posição de destaque no processo de desenvolvimento econômico, social, ambiental e tecnológico de parte muito significativa do leste do território brasileiro.

Juntamente com a Serra da Mantiqueira esta "constitui a mais destacada feição orográfica da borda atlântica do continente sul-americano" (ALMEIDA; CARNEIRO, 1998) e é palco de grandes obras de infraestrutura como o sistema Anchieta-Imigrantes, ferrovias e as rodovias: Mogi-Bertioga; Nova Tamoios; Taubaté-Ubatuba; Cunha-Parati; Pedro Barros-Peruíbe; além da transposição por meio de outros sistemas de transporte terrestre, como é o caso dos polidutos que ligam o polo petroquímico de Cubatão a outras regiões do Sudeste.

Neste contexto o crescente investimento na utilização do subsolo brasileiro como alternativa à falta de espaço gerada pelo desenfreado processo de urbanização e, sobretudo visando a redução de impactos ao meio físico causados pela ação antrópica, no caso da Serra do Mar, pode vir a encontrar sérios fenômenos geológico-geotécnicos na fase construtiva das obras civis, como eventos de ejeção de rocha a partir dos limites de uma escavação, denominados de rockburst.

Em vista das consequências catastróficas geradas por este mecanismo e a necessidade de se aprofundar no conhecimento desse processo pela geologia de engenharia brasileira apresenta-se, a seguir, projeto de iniciação tecnológica iniciado em julho de 2017 e com previsão de término em dezembro de 2018 segundo financiamento da Fundação de Apoio ao Instituto de Pesquisas Tecnológicas (FIPT) a respeito de estudos sobre a possibilidade de desenvolvimento de rockburst em atividades de escavação subterrânea na Serra do Mar.

Assim, acredita-se que os resultados alcançados após a já iniciada etapa de modelagem numérica através do método dos elementos finitos (software RS2, Rocscience) e a consequente conclusão do projeto de pesquisa poderão auxiliar e alertar os profissionais que atuam nas fases iniciais de investigação de terrenos visando a construção de obras subterrâneas, sobretudo no ambiente da Serra do Mar, visto que também pretende-se analisar para o contexto simulado a possibilidade de aplicação de algumas das medidas normalmente adotadas em obras subterrâneas para suportar ou adequar as escavações nas regiões sujeitas ao rockburst.

Adiciona-se que o presente artigo, agora capítulo deste livro, foi primeiramente apresentado como parte do $3^{\circ}$ Simpósio sobre Jovens Profissionais, destinado à divulgação de trabalhos em andamento ou já concluídos de alunos de graduação, do $16^{\circ}$ Congresso Brasileiro de Geologia de Engenharia e Ambiental ocorrido na cidade de São Paulo entre os dias 2 e 6 de setembro de 2018.

\section{GEOLOGIA DA SERRA DO MAR}

Margeando a costa brasileira por cerca de $1.500 \mathrm{~km}$ e recebendo diversas nomenclaturas regionais (Serra da Bocaina, Serra dos Órgãos, Serra do Juqueriquerê etc.) as escarpas da Serra do Mar estendem-se desde o estado do Rio de Janeiro até o norte do estado de Santa Catarina. Segundo Almeida e Carneiro (1998) esta unidade geomorfológica apresenta-se com aspectos variados ao longo de todo seu domínio, indo desde a típica borda de planalto, com altitudes entre 800 e 1.200 m no estado de São Paulo, até a picos de 1.800 m no Paraná e blocos de falha com vertentes abruptas voltadas à Baixada Fluminense, no estado do Rio de Janeiro.

Expondo principalmente rochas do embasamento cristalino esta feição topográfica é composta por diversas associações ígneas e metamórficas geradas nos episódios proterozóicos de colisão continental, com destaque para o evento de colagem que originou o supercontinente Gondwana Ocidental (ALMEIDA; CARNEIRO, 1998; BRITO NEVES; CORDANI, 1991). De maneira posterior à intensa deformação dúctil ocasionada pela convergência tectônica, Hasui e Sadowski (1976) apresentam que durante o CambroOrdoviciano esta região esteve submetida ao desenvolvimento de amplas zonas de cisalhamento de movimentação destral orientadas segundo ENE-WSW a E-W.

Sujeita a diversas etapas de reativação tectônica ao longo da história geológica esta porção do continente sul-americano passou por expressiva deformação rúptil e intrusões de corpos ígneos, seja devido à reativação de zonas de cisalhamento durante o Jurássico Superior ao Cretáceo Inferior (CAMPANHA; ENS, 1996), ao magmatismo alcalino associado à fragmentação continental e abertura do Oceano Atlântico 
(DIAS NETO et al., 2009), ou ainda ao abatimento vertical de blocos durante o Cenozoico no contexto de abertura do Atlântico Sul (DIAS NETO et al., 2009; CAMPANHA; ENS; PONÇANO, 1994).

De forma mais recente, segundo Riccomini e Assumpção (1999), o relaxamento crustal durante o Holoceno foi responsável por dinâmica alteração da direção de máxima compressão da costa brasileira na região da Serra do Mar, ocasionando a formação de falhas e fraturas de atitudes diversas. A seguir, apresenta-se na Figura 1 alguns dos litotipos associados a esta extensa unidade geomorfológica.

Figura 1. Algumas das litologias encontradas na Serra do Mar. Da esquerda para direita, respectivamente, biotita gnaisse/migmatito, granitoides e dique de lamprófiro (cor negra).

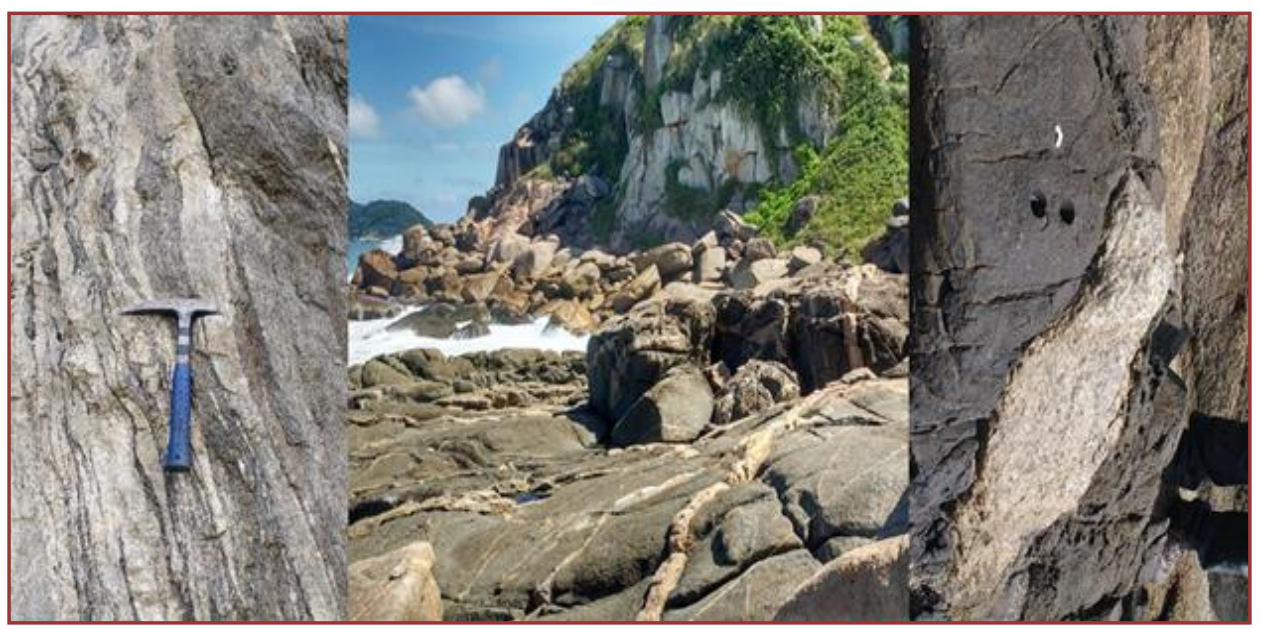

Fonte: Arquivo pessoal.

\section{ROCKBURST}

Segundo Gong et al. (2012) o mecanismo de rockburst pode ser definido como a repentina ruptura e explosão de rocha sã, associada à violenta liberação de energia, a partir dos limites da superfície de uma escavação subterrânea. Embora este fenômeno geológico desencadeado pela alteração do estado de tensões naturais nos maciços rochosos (DAZHAO et al., 2012; SHARAN, 2007) tenha sido estudado ainda de forma pontual no Brasil o interesse de pesquisadores internacionais pela melhor compreensão deste evento, às vezes fatal aos trabalhadores das escavações, data da década de 1830, época em que foram feitos os primeiros relatos de rockburst resultantes da atividade de mineração de carvão na mina de Tin, Inglaterra (ZHOU; QUIAN; YANG, 2011).

A partir de então este fenômeno geológico-geotécnico vem sendo normalmente retratado pela literatura de maneira associada às minerações de carvão em grandes profundidades, onde recebe o nome de coal bump. Contudo, o mecanismo de rockburst não se encontra exclusivamente associado a escavações subterrâneas destinadas à extração deste recurso energético, já que episódios de "explosão de rocha" foram descritos no processo de construção de túneis rodoviários, como o de Heggura, construído entre 1980 e 1982 nos fiordes da Noruega e que, segundo Broch e Sorheim (1984), esteve sujeito a intenso processo de rockburst, e também de túneis utilizados para o transporte de água, como os sete extensos túneis da usina hidrelétrica de Jinping II na China, onde eventos de ejeção de rocha (como o representado pela Figura 2) foram responsáveis pela morte de 7 pessoas e a destruição total de uma TBM (tunnel boring machine) (XIAO et al., 2016).

Para Wang (2018) o desenvolvimento do mecanismo de rockburst é consequência direta do desbalanço entre a quantidade de energia elástica armazenada pela rocha durante a deformação por compressão e a quantidade de energia dissipada durante a escavação, após o fraturamento do litotipo. Segundo o autor se durante o processo de carregamento não houver a dissipação da maior parte da energia elástica armazenada, ao ultrapassar sua envoltória de ruptura a rocha passará por fraturamento dinâmico, ou seja, violenta ruptura associada à conversão do excesso de energia elástica armazenada em energia cinética e a consequente ejeção de blocos, normalmente de formato lenticular (LI; ZHONGLIANG; QIAN, 2012), a partir dos limites da superfície de escavação. 
Figura 2. Rockburst em túnel auxiliar da usina hidrelétrica de Jinping, China.

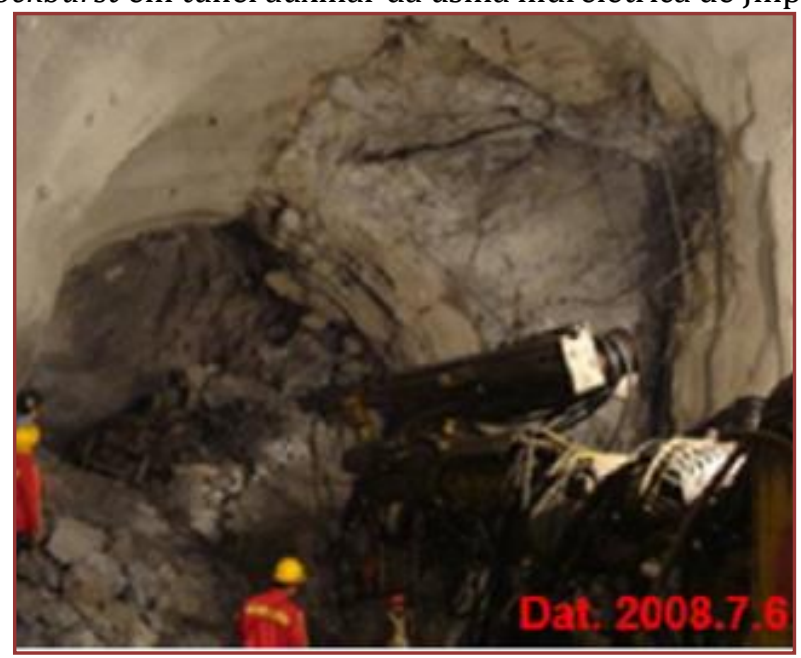

Fonte: Yan et al. (2015)

Wang afirma ainda que este complexo processo dinâmico não-linear, atualmente continua sem ser completamente compreendido, com muitos aspectos a serem decifrados. Desta forma uma grande variedade de métodos vem sendo desenvolvida por pesquisadores internacionais para tentar modelar este comportamento mecânico das rochas, seja por meio do método dos elementos finitos (SHARAN, 2007), pelas teorias de acumulação e liberação de energia (MIAO et al., 2016) com o emprego de conceitos como entropia, ou ainda se utilizando da teoria do caos e dimensão fractal (WANG, 2018).

No Brasil relatos de obras subterrâneas com ocorrência de rockburst foram descritos no estado do Paraná no túnel da usina hidrelétrica Pedro Viriato Parigot de Souza (antiga usina Capivari-Cachoeira), construída na década de 1970 na Serra do Mar. Além disso, problemas de tensões em maciços rochosos são relatados por Sá, Figueiredo e Magalhães (2012) e ainda por Vega e Silva (1999), sendo que estes últimos descrevem episódios de fraturamento e rockburst de baixa intensidade associados à lavra de rochas ornamentais na mina de "Desenhado", localizada no município de Medeiros Neto, sul da Bahia.

\section{TENSÕES EM MACIÇOS ROCHOSOS X ROCKBURST}

Apesar do amplo espectro de teorias e métodos desenvolvidos pela literatura internacional na busca pela melhor compreensão do mecanismo de rockburst a correlação direta entre a presença de altas tensões no maciço rochoso e a acumulação excessiva de energia elástica de deformação (necessária a este fenômeno) mostra-se como unanimidade entre os pesquisadores. Desta forma uma das etapas mais importantes da fase inicial deste projeto de pesquisa de iniciação tecnológica correspondeu à identificação por meio de levantamento bibliográfico de fatores que pudessem levar à presença de altas tensões na Serra do Mar (naturais ou induzidas) e o consequente desencadeamento de "explosões de rocha" em aberturas subterrâneas, como apresenta-se na seção seguinte (item 5).

Segundo Amadei e Stephansson (1997) o estado de tensões in situ em um maciço rochoso não é algo homogêneo no tempo ou espaço, já que resulta da interação dos diversos processos aos quais o corpo de rocha esteve submetido durante o tempo geológico e da presença de heterogeneidades (anisotropias) no maciço (Figura 3), de modo que alterações no estado de tensões podem ocorrer em escala inferior a um metro, como apresentado por Warpinsky e Teufel (1991) para tensões horizontais, se houver alterações significativas nas propriedades do material. 
Figura 3. Comparação do estado de tensões abaixo de um vale entre um maciço homogêneo (esquerda) e um heterogêneo (direita).

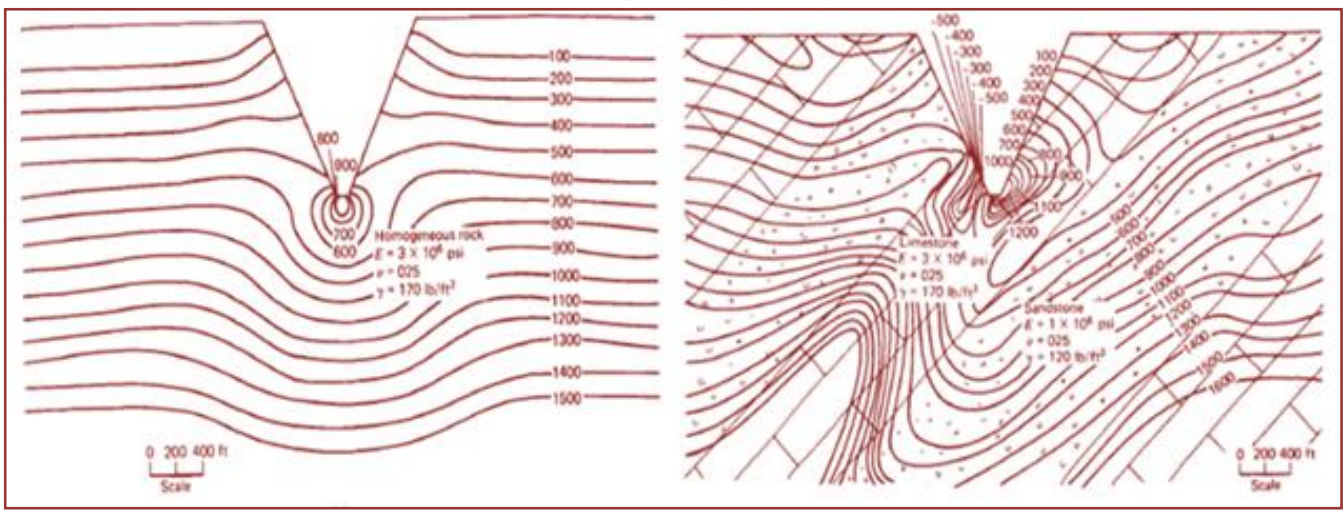

Fonte: Goodman (1989).

Além disso, a presença de altas tensões em determinada porção de um maciço rochoso, submetida ao processo de escavação, pode ser consequência de diversos fatores como a presença de espessa cobertura de solo e rocha, módulo de elasticidade do litotipo, presença de estruturas geológicas (falhas, fraturas, diques ou dobras), efeito da topografia, método de escavação empregado nas obras subterrâneas, taxa de avanço das escavações, tensão tectônica residual, taxa de denudação do maciço, entre outros aspectos (GUO et al., 2017; AMADEI; STEPHANSSON, 1997; MAGALHÃES; HASUI, 1999a).

\section{TENSÕES NA SERRA DO MAR}

A grande complexidade geológica da Serra do Mar no que diz respeito a sua história de formação e à presença de diversas heterogeneidades certamente é responsável por intensa alteração espacial no estado de tensões desta extensa feição geomorfológica. Contudo, algumas informações a respeito do estado de esforços podem ser "ampliadas" (upscaled) para regiões mais amplas que apenas o local em que foram obtidas.

Haimson (1992) apud Magalhães e Hasui (1999b) apresenta medidas de tensões in situ obtidas por meio de ensaios de fraturamento hidráulico em rochas sãs da Serra do Mar, a oeste do centro da cidade de São Sebastião, que indicam para cotas entre $-60 \mathrm{~m}$ e -86 m (abaixo do nível do mar) tensão vertical máxima correspondente ao peso da coluna de rocha sobrejacente e tensões horizontais médias de 7,5 $\pm 0,7 \mathrm{MPa}$ com atitude de N319 \pm 20 para o esforço horizontal mínimo e de $12 \pm 2 \mathrm{MPa}$ e atitude de N49 20 para o esforço horizontal máximo. É mencionado ainda pelos autores que se pode realizar essas medidas por meio de instrumentação nas paredes de furos de investigação do maciço rochoso.

Segundo Amadei e Stephansson (1997) para baixas profundidades o regime de stress em um maciço rochoso tende a se alinhar ao perfil da superfície topográfica local, já em profundidades maiores (como o caso apresentado acima) o estado de tensões normalmente condiz com as tendências geológicas regionais. Tal correlação é ainda reforçada por Gao et al. (2017) ao apresentarem que o tensor de stress atuante em uma região é muito semelhante à média Euclideana do tensor de stress local obtido por medições em campo.

A partir destes conceitos pode-se afirmar que escavações subterrâneas mais profundas na Serra do Mar, praticamente no município de Caraguatatuba e em área não muito distante do local estudado por Magalhães e Hasui (1999b), estariam muito provavelmente sujeitas a semelhante estado anisotrópico de confinamento, dadas as características intrínsecas à região analisada. Para Broch e Sorheim (1984), as escavações subterrâneas submetidas a estado de tensões anisotrópico sofrem com o aumento das componentes cisalhantes nos limites da superfície escavada, podendo desencadear o processo do rockburst.

Além da possibilidade de estarem submetidas a altas tensões cisalhantes, devido à anisotropia de esforços, as escavações na Serra do Mar estão sujeitas a heterogeneidades no estado de tensões do maciço rochoso causadas pela interação entre diferentes famílias de fraturas. Por meio de modelagem numérica utilizando-se do método de FEMDEM (finite and discrete element method), Lei et al. (2017) apresentam que sob estado anisotrópico de esforços um maciço fraturado estará submetido à concentração de altas tensões nas terminações de fraturas extensas e em regiões onde ocorra o cruzamento entre duas ou mais 
destas descontinuidades persistentes. Na publicação os autores ainda destacam que a maneira como a escavação subterrânea intercepta tais descontinuidades é determinante na concentração ou dissipação de tensões ao redor da superfície escavada.

Neste contexto, a intensa deformação rúptil da Serra do Mar, a partir da Era Mesozoica com a reativação de zonas de cisalhamento (CAMPANHA; ENS, 1996) e da dinâmica alteração do estado de tensões durante o Holoceno (Riccomini; Assumpção, 1999), criou um ambiente muito favorável à concentração de tensões devido à interação entre falhas e fraturas geológicas, permitindo a excessiva acumulação de energia elástica de deformação nas proximidades de uma superfície de escavação, como ilustrado pela Figura 4, de modo que esta energia poderá vir a ser dissipada na forma de eventos de "explosão de rocha" (rockburst).

Contudo muitos outros fatores podem ser responsáveis pela presença de altas tensões em maciços rochosos, trazendo riscos a obras de ocupação do subsolo. Um ambiente geológico tão diversificado como a Serra do Mar pode estar sujeito a expressivas acumulações de energia elástica devido não só aos fatores apresentados acima, mas também a aspectos como altas tensões litostáticas verticais, alto módulo de elasticidade atribuído ao litotipo (rochas mais competentes armazenam mais energia elástica), aumento das tensões horizontais como resultado da denudação do maciço (Goodman, 1989), anisotropias de resistência, segundo Gay (1979) diques podem concentrar altas tensões se forem mais resistentes que a rocha encaixante, e até à contribuição de tensões tectônicas residuais, aspecto de grande controvérsia entre os pesquisadores.

Figura 4. Uma das simulações feitas por Lei et al. (2017) segundo estado anisotrópico de esforços, notar a concentração de tensões no entorno da escavação devido à intersecção entre descontinuidades.

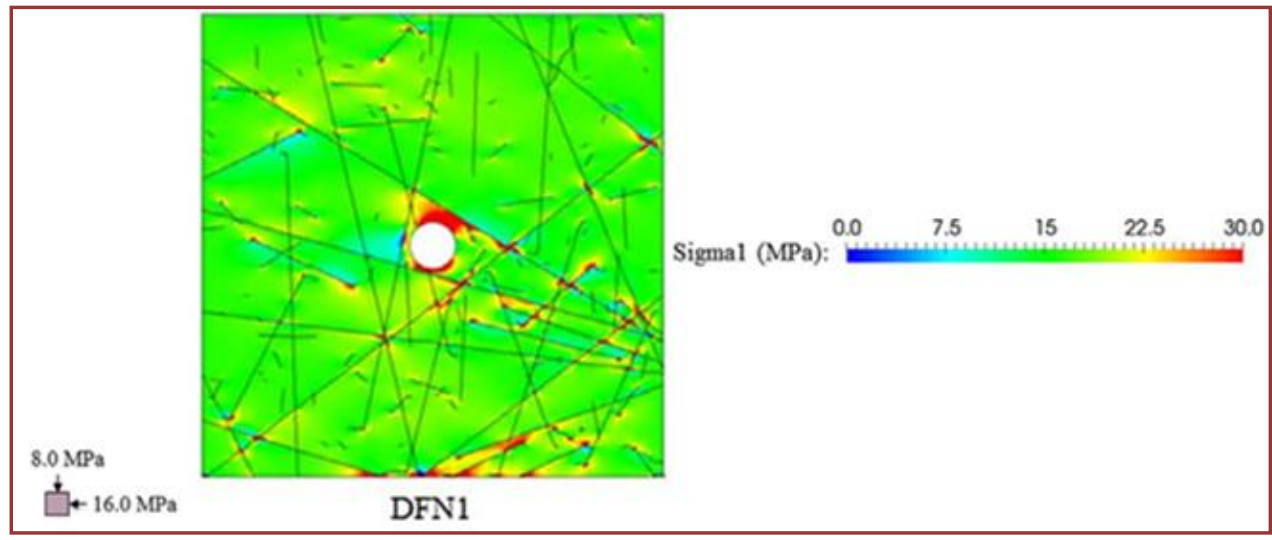

Fonte: Lei et al. (2017).

\section{MODELAGEM NUMÉRICA}

A alta complexidade associada à determinação do estado de tensões em um maciço rochoso e sua correlação com o desenvolvimento do mecanismo de rockburst em escavações subterrâneas exige a elaboração de análise quantitativa através de softwares específicos, que possuam os algoritmos adequados. Por este motivo, no projeto de pesquisa de iniciação tecnológica, ainda em andamento, está sendo realizada a modelagem numérica de tensões atuantes no entorno de hipotética escavação subterrânea na Serra do Mar, buscando compreender o balanço de energia elástica ao redor da abertura e a possibilidade de desencadeamento de rockburst.

Nesta etapa da pesquisa está em uso o programa de análise (em duas dimensões) através do método dos elementos finitos para solos e rochas, $R S 2(v 9.0)$ da Rocscience, para modelar a escavação de túnel subterrâneo hipotético em região específica da Serra do Mar, de modo que toda a caracterização geológica-geotécnica do maciço foi feita pela observação em escala de afloramento (tipos de rocha, levantamento estrutural), análise de fotolineamentos e ensaios de mecânica de rochas para determinação das propriedades geotécnicas dos litotipos encontrados na literatura. Além de analisar a possibilidade de desenvolvimento de rockburst na Serra do Mar por meio da análise numérica pretende-se identificar a contribuição de cada variável (descontinuidades, pressão litostática vertical, tensão tectônica residual, anisotropias de resistência, etc.) na concentração de tensões ao redor da superfície de escavação. 
Como referido anteriormente, atingido este objetivo, pretende-se como atividade final analisar alguns dos tratamentos mais comuns em maciços sujeitos a rockbursts no que diz respeito à viabilidade de aplicação dos mesmos à situação numericamente simulada.

\section{CONSIDERAÇÕES FINAIS}

Como apresentado, a intensificação da ocupação do subsolo brasileiro como alternativa a aspectos de cunho econômico, social e ambiental, pode se deparar com fenômenos geológico-geotécnicos não previstos nas etapas iniciais de uma campanha de investigação do terreno para construção de obras civis subterrâneas, dentre os quais destaca-se o processo do rockburst. Neste contexto a falta de conhecimento ou um estudo mais aprofundado a respeito deste fenômeno por parte dos profissionais que atuam nas construções de obras subterrâneas podem resultar em risco aos trabalhadores e colaboradores que frequentam sistematicamente as escavações, ocasionando inclusive grandes perdas financeiras.

Nesta etapa da pesquisa de iniciação tecnológica foi possível realçar a necessidade em realizar estudos específicos da geologia e da distribuição de tensões no maciço rochoso onde se pretende realizar escavações subterrâneas de modo a identificar eventuais problemas como rockburst. Adicionalmente, como indicou o levantamento bibliográfico, há recursos técnicos para se medir as tensões existentes no maciço por meio de ensaios de fraturamento hidráulico da rocha, e de instrumentações em furos de sondagens.

Os estudos já realizados, ainda que no âmbito internacional, mostram que entre outros aspectos técnicos há relação entre a direção do avanço de uma escavação subterrânea e as tensões reinantes no maciço rochoso, que afeta diretamente na intensidade do processo do rockburst. Portanto, se nas etapas iniciais de investigação para construção de obras subterrâneas, por exemplo, essa evidência for caracterizada podese promover estudos alternativos do eixo da escavação no sentido em reduzir a intensidade do processo do rockburst. Adicionalmente, por outro lado, pode-se antecipar que há projetos de engenharia que promovem a contenção de blocos de rocha que se desprendem das paredes escavadas.

Assim, os conhecimentos obtidos na busca pela melhor compreensão das "explosões de rocha" a partir dos limites de uma escavação poderão ser de grande utilidade no futuro próximo, principalmente no que diz respeito à análise quantitativa do processo e à tomada de decisões. Registra-se, ainda, a necessidade de se instrumentar, durante a vida útil da operação das construções subterrâneas, os trechos onde o processo de rockburst foi identificado nas escavações. Conclui-se, portanto, nesta etapa da pesquisa, que há muitos aspectos a serem desenvolvidos pelos pesquisadores, sobretudo da comunidade científica brasileira.

\section{AGRADECIMENTOS}

Gostaria de agradecer primeiramente a meus orientadores Wilson Shoji Iyomasa e Edilson Pizzato por todo apoio e orientação concedidos durante o desenvolvimento do projeto de iniciação tecnológica e, principalmente, meus agradecimentos à Fundação de Apoio ao IPT (FIPT) pelo financiamento desta bolsa de pesquisa de graduação.

Por fim, agradeço também a todos os funcionários da Seção de Geotecnia do Centro de Obras de Infraestrutura (CT-Obras) do IPT por terem me acolhido tão bem em seu local de trabalho.

\section{REFERÊNCIAS}

[1] Almeida, Fernando Flávio Marques de; Carneiro, Celso Dal Ré. Origem e Evolução Da Serra do Mar. Revista Brasileira de Geociências, [s. L.], v. 28, p.135-150, jun. 1998.

[2] Amadei, Bernard; Stephansson, Ove. Rock Stress and Its Measurement. Londres: Chapman \& Hall, 1997. 490

p.

[3] Brito Neves, B. B.; Cordani, U. G. Tectonic evolution of South America during late proterozoic. Precambrian Research, v. 33, p. 23-40, 1991.

[4] Broch, E.; SORHEIM, S.. Experiences from the Planning, Construction and Supporting of a Road Tunnel Subjected to Heavy Rockbursting. Rock Mechanics And Rock Engineering, [s.l.], v. 17, p.15-35, 1984.

[5] Campanha, G. A. C.; ENS, H. H.. Estruturação geológica da região da serra do Juqueriquerê, São Sebastião, SP. Bol.IG-USP, Série Científica, São Paulo, v. 27, p.41-49, 1996. 
[6] Campanha, Ginaldo A.C.; ENS, Hendrik H.; Ponçano, Waldir L.. Análise morfotectônica do planalto do Juqueriquerê, São Sebastião. Revista Brasileira de Geociências, São Paulo, v. 24, p.32-42, mar. 1994.

[7] Dazhao, Song et al. Rock burst prevention based on dissipative structure theory. International Journal Of Mining Science And Technology, [s.l.], v. 22, p.159-163, 2012. Elsevier BV.

[8] Dias Neto, Coriolano de Marins e et al. Os Anfibolitos do Complexo Costeiro na Região de São Sebastião, SP. Geologia USP: Série Científica, São Paulo, v. 9, n. 3, p.71-87, out. 2009.

[9] Gao, Ke et al. Investigating the Relationship Between Far-Field Stress and Local Values of the Stress Tensor. Procedia Engineering, [s. l.], v. 191, p.536-542, 2017.

[10] Gay, N. C.. The state of stress in a large dyke on E.R.P.M., Boksburg, South Africa. International Journal Of Rock Mechanics \& Mining Sciences, [s.l.], v. 16, p.179-185, 1979.

[11] Gong, Q. M. et al. Rock burst and slabbing failure and its influence on TBM excavation at headrace tunnels in Jinping II hydropower station. Engineering Geology, [s.l.], v. 124, p.98-108, jan. 2012. Elsevier BV. http://dx.doi.org/10.1016/j.enggeo.2011.10.007.

[12] Goodman., Richard E.. Introduction to Rock Mechanics. 2. ed. Canada: John Wiley \& Sons, 1989. 576 p.

[13] Guo, Wei-yao et al. Progressive mitigation method of rock bursts under complicated geological conditions. International Journal of Rock Mechanics And Mining Sciences, [s.l.], v. 96, p.11-22, jul. 2017. Elsevier BV. http://dx.doi.org/10.1016/j.ijrmms.2017.04.011

[14] Haimson, B. C.. Hydraulic fracturing stresses measurements at the São Sebastião terminal, Petrobras. 1992.

[15] Hasui, Y.; Sadowski, G. R. Evolução geológica do Pré-Cambriano na região sudeste do Estado de São Paulo. Revista Brasileira de Geociências, v. 6, n. 3, p. 182-200, 1976.

[16] Lei, Qinghua et al. Role of natural fractures in damage evolution around tunnel excavation in fractured rocks. Engineering Geology, [s. l.], v. 231, p.100-113, 2017.

[17] Li, Wang; Zhongliang, Lu; Qian, Gao. A numerical study of rock burst development and strain energy release. International Journal Of Mining Science And Technology, [s.l], v. 22, p.675-680, 2012.

[18] Magalhães, F. S.; Hasui, Y.. Campo de tensão. Parte I: Aspectos gerais. Geociências (UNESP. Impresso). São Paulo, v. 18, n.1, p. 69-83, 1999a.

[19] Magalhães, F. S.; HASUI, Y.. Campo de tensão. Parte II: Obtenção por análise de falhas e determinação in situ em quatro áreas. Geociências (UNESP. Impresso). São Paulo, v. 18, n.1, p. 85-127, 1999b.

[20] Miao, Sheng-jun et al. Rock burst prediction based on in-situ stress and energy accumulation theory. International Journal Of Rock Mechanics \& Mining Sciences, [s.l.], v. 83, p.86-94, 2016. Elsevier BV.

[21] Riccomini, Claudio; Assumpção, Marcelo. Quaternary tectonics in Brazil. Episodes, [s.l.], v. 22, n. 3, p.221-225, set. 1999.

[22] Sá, Gilvan; Figueiredo, Rodrigo P. de; Magalhães, Fábio Soares. Ruptura Do Talude Sudeste Da Mina De N4E Um Estudo De Caso, Carajás, Estado Do Pará. Revista Brasileira de Geologia de Engenharia e Ambiental, São Paulo, v. 2, n. 2, p.115-129, 2012.

[23] Sharan, S.K.. A finite element perturbation method for the prediction of rockburst. Computers And Structures, [s.l.], v. 85, p.1304-1309, jan. 2007. Elsevier BV.

[24] Vega, Hugo Antonio Merconchini; Silva, Lineu Azuaga Ayres da. Problemas relacionados a tensões naturais na lavra de rochas ornamentais. 1999. 212 f. Dissertação (Mestrado) - Curso de Engenharia de Minas, Pmi, Universidade de São Paulo, São Paulo, 1999.

[25] Wang, Chunlai. Evolution, Monitoring and Predicting Models of Rockburst: Precursor Information for Rock Failure. Beijing: Springer, 2018. 199 p.

[26] Warpinsky, N. R.; Teufel, L. W.. In-situ stress measurements at Rainier Mesa, Nevada Test Site - influence of topography and lithology on the stress state in tuff. International Journal Of Rock Mechanics \& Mining Sciences, [s.l.], v. 28, p.143-161, 1991.

[27] Xiao, Y. X. et al. Rock mass failure mechanisms during the evolution process of rockbursts in tunnels. International Journal Of Rock Mechanics \& Mining Sciences, [s.l.], v. 83, p.174-181, 2016. Elsevier BV.

[28] Yan, Peng et al. Mitigation of rock burst events by blasting techniques during deep-tunnel excavation. Engineering Geology, [s.l.], v. 188, p.126-136, 2015. Elsevier BV. http://dx.doi.org/10.1016/j.enggeo.2015.01.011. 
[29] ZHOU, X.P.; Qian, Q.H.; YANG, H.G.. Rock burst of deep circular tunnels surrounded by weakened rock mass with cracks. Theoretical And Applied Fracture Mechanics, [s.l.], v. 56, n. 2, p.79-88, out. 2011. Elsevier BV. http://dx.doi.org/10.1016/j.tafmec.2011.10.003.

[30] More: Mecanismo online para referências, versão 2.0. Florianópolis: UFSC Rexlab, 2013. Disponível em: « http://www.more.ufsc.br/ >. Acesso em: 25/04/2018. 


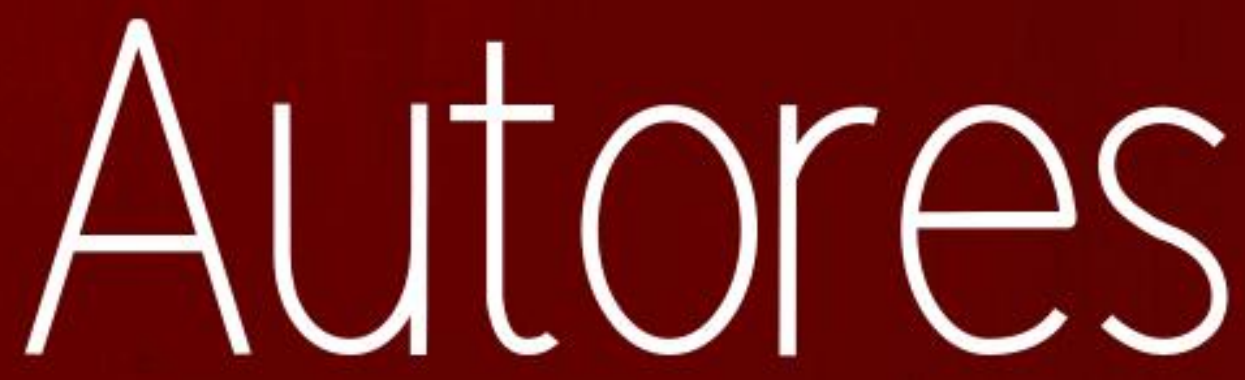




\section{DAVILSON EDUARDO ANDRADE (ORGANIZADOR)}

Graduado em geologia pela UFMG em 1989. Mestrado em Geofísica pela UFBA em 1992.

Possui 25 anos de experiência na Indústria de Petróleo (área de Exploração e Produção).

\section{AMANDA FABRIN}

Formada em Engenharia Civil pela Universidade Federal de Santa Catarina (2017). Intercâmbio tipo sanduíche realizado na University of Toronto (Canadá/ 2013-2014).

\section{CANDIDO BORDEAUX REGO NETO}

Candido Bordeaux Rego Neto, Geólogo (UFRJ-1979), Mestre em Geologia de Engenharia (UFRJ-1988), Diplome d'Expert em Engenharia de Segurança e Meio Ambiente na Mineração (École des Mines d'Alès-1992), especialização em Urbanismo pelo Nagoya Urban Institute (JICA-2002), Doutor em Engenharia de Produção e Sistemas (UFSC-2003), Pós-Doutor em Geodinâmica Externa (Universidad de Cantabria-2006), Pós-Doutor em Dinâmica da Paisagem (Wageningen University-2010). Experiência de mais de 30 anos em planejamento territorial e meio ambiente.

\section{CAROLINE FORESTTI OLIVEIRA}

Mestre em Engenharia Civil com ênfase em Geotecnia pela Universidade Federal do Espírito Santo em 2018. Atualmente doutoranda na Université Clermont-Auvergne. Atuou em pesquisas relacionadas a pavimentação, reuso de coprodutos industriais, estabilização de solos lateríticos, geotecnia experimental e determinação de parâmetros mecânicos in situ.

\section{CLEVERSON ALVES DE LIMA}

Engenheiro Civil (UFV). Mestre e Doutor em Engenharia Civil/Geotecnia pela Universidade Federal de Viçosa. Professor Assistente do DCET/UESC

\section{CLOVIS GONZATTI}

Graduado em Engenharia de Minas pela Universidade Federal do Rio Grande do Sul - UFRGS (1987), mestre em Engenharia pela Escola de Engenharia de São Carlos - EESC da Universidade de São Paulo - USP (1994) e doutor em Geotecnia pela mesma EESC/USP (2008). Entre 1991 e 2011 foi pesquisador da Fundação de Ciência e Tecnologia do Estado do Rio Grande do Sul - CIENTEC, em Porto Alegre - RS. Desde 2011 é Professor Adjunto do Departamento de Mineralogia e Petrologia do Instituto de Geociências da Universidade Federal do Rio Grande do Sul, responsável pelas disciplinas de Geologia de Engenharia e Mecânica das Rochas no curso de Geologia. Tem experiência nas áreas de Engenharia de Minas e Engenharia Civil, com ênfase em Mecânica das Rochas e Geologia de Engenharia, atuando principalmente nos temas: dimensionamento de pilares em minas de carvão e desenvolvimento de software, mapeamento geotécnico de maciços rochoso, caracterização mecânica e tecnológica de materiais rochosos para uso na construção civil, análise de estabilidade de taludes em rocha, mapeamento geotécnico e classificação geomecânica de maciço.

\section{DANIEL SILVA JAQUES}

Mestre e doutorando em Engenharia Civil - Área de concentração: Geotecnia Analítica e Experimental - pela Universidade Federal de Viçosa (UFV) concluiu a graduação em Engenharia Ambiental pela Universidade Federal de Ouro Preto (UFOP) no ano de 2011. Desde Abril de 2018 faz parte do corpo docente do Curso de Engenharia Ambiental - Campus Balsas - da Universidade Federal do Maranhão, em regime de dedicação exclusiva. Suas linhas de pesquisa e de desenvolvimento de projetos concentram-se nas áreas correlatas à Geologia de Engenharia, Geotecnia e Avaliação de Impactos Ambientais. 


\section{DIANA FERREIRA DE FREITAS}

Graduada em Engenharia Agronômica pela Universidade Federal Rural do Semi-Árido (UFERSA). Mestre e Doutora em Solos e Nutrição de Plantas pela Universidade Federal de Viçosa (UFV). Atualmente faz parte do corpo docente da Universidade Federal Rural de Pernambuco, Unidade Acadêmica de Serra Talhada (UFRPE/UAST). Tem experiência profissional nas seguintes áreas de atuação: Processos pedogenéticos e planejamento de uso do solo, gênese e classificação dos solos, levantamento e mapeamento de solos, etnopedologia e matéria orgânica do solo.

\section{EDILSON PIZZATO}

Formado em Geologia pela Universidade de São Paulo (1989), com mestrado e doutorado em Engenharia Mineral pela Escola Politécnica da Universidade de São Paulo, departamento de Engenharia de Minas (2009). Desde 2010 é Professor Doutor no Departamento de Geologia Sedimentar e Ambiental do Instituto de Geociências da Universidade de São Paulo. Exerce as atividades de pesquisa e ensino direcionadas à área de Geologia de Engenharia, com ênfase em cartografia geotécnica, estabilidade de taludes em solo e rocha e caracterização de maciços rochosos. Responsável pelas disciplinas: Geologia de Engenharia, Metodologias de Mapeamento Geotécnico, Geologia e Urbanização, na graduação e Cartografia Geotécnica e Mecânica de Rochas Aplicada à Engenharia Civil, na Pós-graduação.

\section{EDINALDO DINIZ DE SOUZA JÚNIOR}

Graduado em Engenheiro Civil e Bacharel em Ciência e Tecnologia e Graduado pela Universidade Federal Rural do Semi-Árido. Atua na área de gerenciamento de obras, coordenação de mão-de-obra e fiscalização.

\section{EDUARDO ANTÔNIO GOMES MARQUES}

Geólogo, PhD. Professor Titular do Departamento de Engenharia Civil/UFV

\section{EULA PAULA DA SILVA SANTOS}

Graduanda em Engenharia Agronômica pela Universidade Federal Rural do Semi-Árido (UFERSA). Tem experiência na área de Manejo do Solo e Agroecologia.

\section{EULENE FRANCISCO DA SILVA}

Graduada em Engenharia Agronômica pela Universidade Federal do Mato Grosso do Sul (UFMS) . Mestre em Agronomia com Área de Concentração em Produção Vegetal na mesma instituição. Doutorado e Pós Doutorado em Solos e Nutrição de Plantas na Universidade Federal de Viçosa (UFV). Atuou como professora visitante na Universidade Federal da Grande Dourados (UFGD) e, atualmente faz parte do corpo docente da Universidade Federal Rural do Semi Árido (UFERSA). Tem experiência na área de Agronomia, com ênfase em Fertilidade do Solo e Adubação, Matéria Orgânica do Solo, Geologia e Pedologia.

\section{GETÚLIO FONSECA DOMINGUES}

Engenheiro Florestal (UFV). Mestre e Doutor em Ciência Florestal/UFV. Pós Doutorando em Ciência Florestal/UFV 


\section{GISELE MARILHA PEREIRA REGINATTO}

Pesquisadora e Doutoranda do Programa de Pós-Graduação em Engenharia Civil da Universidade Federal de Santa Catarina (UFSC), na área de concentração de Infraestrutura e Gerência Viária, linha de pesquisa em Geotecnia. Graduação em Engenharia Civil pela UFSC (2007) e Mestrado em Engenharia Civil (2013), pela mesma Instituição e área de concentração. Experiência na área de Engenharia Civil, atuando principalmente nos seguintes temas: gerenciamento de desastres naturais, mapeamento geotécnico, monitoramento estrutural e hidrogeológico, estruturas de contenção, aterros reforçados sobre solos moles, qualidade na execução jet grouting e execução de ensaios geotécnicos.

\section{ISABEL KAUFMANN DE ALMEIDA}

Professora Adjunta na Universidade Federal de Mato Grosso do Sul. Doutora (2014) e Mestra (2009) em Tecnologias Ambientais - Saneamento Ambiental e Recursos Hídricos pela Universidade Federal de Mato Grosso do Sul. Graduada em Engenharia Civil pela Pontifícia Universidade Católica do Rio Grande do Sul (1994). Revisora de periódicos: WRM, RBRH, Geociências, JHH, JAWRA. Líder do Grupo de Pesquisa ModelHy.

\section{JOÃO ALBERTO FIORENTINI}

Graduado em Geologia pela Universidade Federal do Rio Grande do Sul - UFRGS (1982), mestre em Engenharia pela mesma UFRGS (2002). Atuou a partir de 1983 na pesquisa mineral e mineração a céu aberto e subterrânea com minérios de estanho, ouro primário e água subterrânea. Em 1989 ingressou na Fundação de Ciência e Tecnologia do Estado do Rio Grande do Sul - CIENTEC, onde atua na área de Geotecnia e na coordenação dos Laboratórios de Mecânica e Tecnologia de Rochas e de Asfalto e Misturas Asfálticas, com ênfase nas áreas de caracterização geomecânica de maciços rochosos, caracterização de materiais rochosos e misturas asfálticas para uso na construção civil.

\section{JOÃO PEDRO SILVA PEREIRA}

Graduando em Geologia na Universidade de São Paulo com formação prevista para fevereiro de 2020. Atualmente é Pesquisador Visitante na Seção de Geotecnia (CT-Obras) do Instituto de Pesquisas Tecnológicas do Estado de São Paulo (IPT) e ex-bolsista do Programa de Iniciação Tecnológica FIPT (julho 2017-dezembro 2018).

\section{KALIU TEIXEIRA}

Geógrafo pela Universidade Federal de Santa Catarina - UFSC. Estudante do curso de Mestrado do Programa em Engenharia de Transportes e Gestão Territorial da UFSC. Atua como Gerente de Cadastro Urbano, Geoprocessamento e Pesquisa no Instituto de Planejamento Urbano de Florianópolis - IPUF. Membro da Sociedade Brasileira de Cartografia - SBC, integrante da comissão VII - Sistemas de Informação Geográfica. Tem experiência na área da Geoinformação, com ênfase em Banco de Dados Geográficos, Sistemas de Informação Geográfica e Análise Espacial.

\section{KLINGER SENRA REZENDE}

Mestre e doutorando em Geotecnia Analítica e Experimental pela Universidade Federal de Viçosa, tendo concluído sua graduação em Engenharia Civil (2014) nesta mesma universidade. Atuou na área da Mecânica das Rochas em seu Trabalho de Conclusão de Curso, Mestrado e continua seu doutoramento nesta mesma área. Leciona disciplinas de Mecânica dos Solos, Mecânica dos Solos Avançada, Barragens, Mecânica das Rochas e Materiais de Construção Civil na Faculdade de Ciências e Tecnologia de Viçosa - Univiçosa, Viçosa-MG, tendo também orientado trinta e dois trabalhos de conclusão de curso e cinco iniciações científicas desde 2016. Suas principais linhas de pesquisa e de desenvolvimento de projetos concentram-se nas áreas correlatas à Geologia de Engenharia e Geotecnia. 


\section{LAIS EMILY ASSIS}

Engenheira Ambiental (UEMG). Msc. em Engenharia Civil - Geotecnia - UFV. Doutoranda em Engenharia Civil - Geotecnia - UFV

\section{MARCELO TAVARES GURGEL}

Graduado em Engenharia Agronômica pela Universidade Federal Rural do Semi-Árido (UFERSA). Mestre em Engenharia Agrícola pela Universidade Federal da Paraíba e Doutor em Recursos Naturais pela Universidade Federal de Campina Grande. Atualmente faz parte do corpo docente da Universidade Federal Rural do Semi-Árido. Líder do Grupo de Pesquisa Núcleo de Estudos em Ambientes Hipersalinos do Semiárido Brasileiro. Tem experiência nas áreas de Agronomia, Engenharia Agrícola e Ciências Ambientais.

\section{MILENA DE BRITO ESPINOSA}

Mestre em Tecnologias Ambientais pela Universidade Federal de Mato Grosso do Sul. Possui graduação em Engenharia Sanitária e Ambiental pela Universidade Federal de Santa Catarina (2016). Tem experiência em pesquisas científicas na área de modelagem matemática de águas subterrâneas, aproveitamento da água da chuva e reuso de água cinza.

\section{NEEMIAS ALMEIDA DIAS}

Graduado em Engenharia Civil pela Universidade Federal do Espírito Santo (2014), mestre em Engenharia Civil (Geotecnia e Fundações) pela mesma instituição (2017). Atua, principalmente, em projetos relacionados a geotecnia experimental, reaproveitamento de resíduos industriais sólidos e comportamento reológico de rejeitos de mineração. Atualmente é professor adjunto da Universidade Vila Velha.

\section{PÂMELA BETIATTO}

Graduanda do curso de Engenharia Civil da Universidade Federal de Santa Catarina - UFSC. Atualmente atua no setor de geotecnia do Centro Universitário de Estudos e Pesquisas sobre Desastres (CEPED UFSC), em projeto de extensão para análise de setores de risco a movimentos de massa no município de Santo Amaro da Imperatriz/SC. Atuou como bolsista PIBIC do Laboratório de Mapeamento Geotécnico (LAMGEO) da UFSC, onde desenvolveu o projeto intitulado "Criação de banco de dados geotécnico de Santa Catarina" . Técnica em Agrimensura pela Universidade Tecnológica Federal do Paraná - Campus Pato Branco.

\section{PÂMELA BOGO PESSINI}

Graduanda do curso de Engenharia Civil na Universidade Federal de Santa Catarina. Bolsista do Laboratório de Mapeamento Geotécnico da UFSC (LAMGEO) entre o período de abril a setembro de 2018. Outros projetos envolvem a participação, durante o ano de 2017, no Núcleo de Educação Ambiental da UFSC. Atualmente estagiária na empresa Prosenge Projetos e Engenharia, atuando no auxílio em projetos de segurança de barragens hidrelétricas, e demais projetos associados.

\section{PATRÍCIO JOSÉ MOREIRA PIRES}

Professor adjunto do Departamento de engenharia civil da Universidade Federal do Espírito Santo. Graduado em Engenharia Civil pela Universidade Federal da Paraíba, mestrado e doutorado em Engenharia Civil pela Pontifícia Universidade Católica do Rio de Janeiro. Tem experiência na área de Geotecnia ambiental, atuando principalmente nos seguintes temas: geotecnia experimental, recuperação de áreas degradadas, tratamento e disposição de resíduos sólidos. 


\section{RAFAEL AUGUSTO DOS REIS HIGASHI}

Engenheiro Civil com mestrado e doutorado em Engenharia Civil (Infraestrutura Viária) pela Universidade Federal de Santa Catarina (2002/2006). Atualmente é professor Associado DE da UFSC, atuante na graduação e no Programa de Pós-graduação em Gestão Territorial e Transportes (PPGTG) e no Programa de Pós-Graduação em Desastres Naturais (PPGDN). Possui experiência na área de Engenharia Civil, com ênfase em geotecnia, atuando principalmente nos seguintes temas: Mapeamento geotécnico, Estabilização de encostas e uso de Sistemas de Informações Geográficas.

\section{REGINA CELIA DE OLIVEIRA BRASIL DELGADO}

Graduada em Geologia Bacharelado pela Universidade Federal do Rio Grande do Norte (UFRN). Mestre em Geociências pela UFRN e, Doutora em Química pela UFRN. Atualmente faz parte do corpo docente da Universidade Federal Rural do Semi-Árido (UFERSA). Tem experiência na área de Geociências e Química, com ênfase em geologia, combustíveis e biocombustíveis atuando principalmente nos seguintes temas: biodiesel, óleo diesel, gasolina, etanol, flex-fuel e geologia do petróleo.

\section{ROBERVAN ALVES DE ARAUJO}

Docente no Instituto Federal de Mato Grosso do Sul. Mestrando do Programa de Tecnologias Ambientais na Universidade Federal de Mato Grosso do Sul (UFMS) com pesquisa de fomento FINEP. Possui graduação em bacharelado em Engenharia Civil pela UFMS. Membro do grupo de pesquisa de Tecnologia Ambientais/UFMS. Atua em pesquisas em recursos hídricos (hidráulica e hidrologia) e sustentabilidade (materiais alternativos e eficiência energética).

\section{RODRIGO ROGÉRIO CERQUEIRA DA SILVA}

Professor de Engenharia Civil da Universidade Nove de julho, ministra as disciplinas de Fundações e obras de Terra, Contenções de encostas e Mecânica dos solos. Tem experiência na área de Engenharia Civil, com ênfase em fundações, obras de terra, contenções de encostas, tratamento de solos e inspeção de materiais e estruturas por meio de ensaios não destrutivos por ultrassom. Coordenador técnico da empresa PS Instrumentação Geotécnica e consultor técnico da empresa Geogrouting Fundações e Contenções Especiais.

\section{SADY JÚNIOR MARTINS DA COSTA DE MENEZES}

Engenheiro Agrícola e Ambiental (UFV). Mestre em Recursos Hídricos, DEA/UFV. Doutor em Ciência Florestal, DEF/UFV. Professor Adjunto, Instituto Três Rios/UFRRJ

\section{SARAH LACERDA FARIAS}

Mestranda do Programa de Tecnologias Ambientais na Universidade Federal de Mato Grosso do Sul. Possui graduação em Tecnologia em Gestão Ambiental pelo Instituto Federal de Educação, Ciência e Tecnologia do Ceará (2008). Tem experiência em consultoria, fiscalização, licenciamento e monitoramento ambiental e na área de Biotecnologia, atuando principalmente em tratamento de efluentes e microalgas.

\section{THAYNARA D'AVALO CENTURIÃO}

Mestranda do Programa de Tecnologias Ambientais na Universidade Federal de Mato Grosso do Sul. Possui graduação em licenciatura - Ciências Biológicas pela Universidade Federal de Mato Grosso do Sul (2017). Tem experiência na área de limnologia, atuando em projetos de pesquisa em recursos hídricos com ênfase em bioindicadores, ecotoxicologia e a fauna de águas subterrâneas. 


\section{WILSON SHOJI IYOMASA}

Graduado em Geologia pelo Instituto de Geociências da Universidade de São Paulo (1976), mestre em Geociências e Meio Ambiente pelo Instituto de Geociências e Ciências Exatas da Universidade Estadual Paulista (1994) e doutor em Geotecnia pela Escola de Engenharia de São Carlos da Universidade de São Paulo (2000). Atualmente é pesquisador III do Instituto de Pesquisas Tecnológicas do Estado de São Paulo e coordenador e professor do curso de Especialização do IPT e ex-professor da Universidade Anhembi Morumbi. Tem experiência na área de Geologia de Engenharia, com ênfase em Geotecnia associado às questões construtivas e ambientais, atuando principalmente nos seguintes temas: investigação geológico-geotécnica, tratamento de maciços (barragens, túneis e rodovias), classificação geomecânica de maciços, prospecção em área urbana para construção de obras de infraestrutura (túneis metroviários e do sistema viário de veículos, instalação de dutos, estruturas de detenção de cheias - "piscinões"). Atua também nos estudos de avaliação de maciços para instalação de fundações especiais, avaliação e análise de projetos básicos e executivos de classes de maciços. 
Agência Brasileira do ISBN ISBN 978-85-7042-112-8

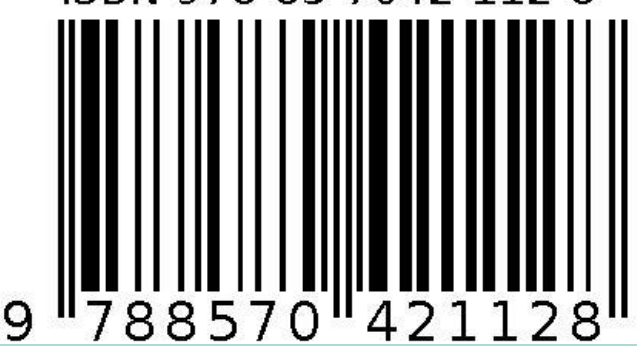

